\title{
Growth and Development in the Global Political Economy
}

Social structures of accumulation and modes of regulation

Phillip Anthony O'Hara

Routledge Frontiers of Political Economy

Routledge
Taylor \& francis Group
Sag

\section{Also available as a printed book see title verso for ISBN details}




\section{Growth and Development in the Global Political Economy}

Recent institutional changes have seen the increasing dominance of globalization and neoliberalism in the world economy. As markets have been deregulated, privatization and unproductive government spending have been promoted. Yet the greater volatility of capitals, the emergence of many financial crises, a decline in trust, and environmental problems have cast doubt on the effectiveness of neoliberal globalization.

This book studies the impact of neoliberal globalization on growth and development in the world economy. It scrutinizes whether new social structures of accumulation or modes of regulation have emerged to promote long-term socioeconomic performance in the global economy during the early years of the twenty-first century. Special reference is given to the specific performance of neoliberal governance; transnational corporations; global institutions of money, trade, and production; international relations of war and terrorism; financial institutions; and the family-community environment.

It is a comprehensive analysis of the degree to which institutional development has managed to promote socioeconomic performance in the global economy. It also presents a thorough policy program of action for long wave upswing in the world economy. It will be especially useful for those scholars and students concerned with issues of governance, global political economy, institutions, and macroeconomics.

Phillip Anthony O'Hara is Professor of Global Political Economy and Governance and Director of the Global Political Economy Research Unit, at Curtin University, Perth, Australia. He won the European Association for Evolutionary Political Economy "2002 Gunnar Myrdal Prize” for Marx, Veblen and Contemporary Institutional Political Economy (Elgar, 2000); is the editor of Global Political Economy and the Wealth of Nations (Routledge, 2004) as well as the Encyclopedia of Political Economy (Routledge, 2001, paper edition). He is the author of over 60 articles in scholarly journals and edited books, such as the Review of International Political Economy, Review of Radical Political Economics, Journal of Economic Issues, Review of Social Economy, and European Journal of the History of Economic Thought. 


\section{Reviews of Growth and Development in the Global Political Economy}

“I am delighted to endorse Phil O’Hara’s new volume. Many years ago I examined his Honours dissertation at Murdoch University on Marx's theories of crisis. It was an outstanding piece of scholarship and I recognised then that a star had been born. His many contributions since show how right I was! Growth and Development in the Global Political Economy is the jewel in his crown. It contains a superb intertwining of historical, political, economic and institutional analysis of modern global capitalism, its successes and failures. It is also a critique of the claims of neoliberal analysis, and the provision of an alternative illuminating analysis; combined with detailed suggestions for the creation of institutions that will go some way towards ensuring that potential sustainable development will be achieved in a manner that helps all the world's citizens and preserves the physical environment for future generations. O'Hara has written a notable book which ought to be read by all serious economists, social scientists, concerned citizens, politicians and policy makers.” Professor G.C.Harcourt, Cambridge University, UK.

“In Growth and Development in the Global Political Economy, Phil O’Hara critically surveys the contemporary performance of the world economy, and comes to some very poignant results. The trends associated with neoliberal globalisation are shown to be complex, contradictory and conflicting. Global deregulation, greater rule of capital, and expansion of market relations have produced asymmetrical results. On the one hand, there has been more mobility of capital, foreign direct investment, and global bank credit; but also financial instability, insufficient demand, global conflict and declining trust and sociality. These contradictory results have, on balance, inhibited global growth and development through a continuation of long wave downswing, which can only be rectified by significant changes in institutions and governance. Phil O'Hara has produced a masterly work that shows how the economic, political and cultural factors interplay in the global political economy." Professor Howard J.Sherman, University of California, USA.

“In this original and provocative work, Phil O'Hara provides a comprehensive critique of neoliberalism on a world scale. He applies the 'social structures of accumulation' (regulation school) approach to the explanation of long-term socioeconomic change, constructing a model of the Global System of Power and Accumulation that integrates financial, political, cultural and military dimensions of the new world disorder. O'Hara analyses the hegemonic role of the United States and the associated international economic institutions, and identifies some fundamental contradictions, both economic (effective demand failure, financial crises) and social (growing anomie, collapse of family and community relations). These contradictions, he argues, inhibit global economic development and generate international political tensions, causing terrorism and war. O’Hara concludes by proposing a far-reaching and coherent set of alternatives to 
neoliberal global governance. Growth and Development in the Global Political Economy is required reading for anyone with a serious interest in political economy or international relations." Professor John King, La Trobe University, Australia.

"Over the last decade Phil O'Hara has emerged as a major contributor to political economy, the holistic analysis of the relation of power and culture to the economic process. In Growth and Development in the Global Political Economy he brings together a broad literature and applies it to the present era of neoliberal globalization. He addresses the central question as to whether or not this USA-hegemonic governance regime is likely to provide a stable trajectory of growth and accumulation. In analysing this complex question O'Hara examines governance in its broadest sense, including culture and identity politics, family structure and gender relationships, financial architecture, international trade, and corporate power. O’Hara concludes that substantial social reform will be necessary to convert the present institutional configuration to a sustainable, progressive path, and offers a stimulating overview of this necessary reform. No one is doing better work than O'Hara in holistic, evolutionary political economy; this book deserves a very wide readership." Professor James Ronald Stanfield, Colorado State University, USA.

“In this book, Philip O'Hara grapples with the big issues of contemporary political economy. He asks where the world system is heading and finds serious trouble ahead. Utilizing a methodological framework that stresses the interplay of institutions and economic outcomes, he offers a critique of the dominant neoliberal model, with its faith in the free market as the centerpiece of society. He makes a convincing case that neoliberalism is not bringing an economic rebirth, as its advocates claim, but rather is serving as an obstacle to economic and social development. Growth and Development in the Global Political Economy contributes to the growing literature that points out that the neoliberal emperor truly has no clothes." Professor David M.Kotz, University of Massachusetts at Amherst, USA. 


\title{
Routledge Frontiers of Political Economy
}

\author{
1 Equilibrium versus Understanding \\ Towards the rehumanization of economics within social theory \\ Mark Addleson \\ 2 Evolution, Order and Complexity \\ Edited by Elias L.Khalil and Kenneth E.Boulding \\ 3 Interactions in Political Economy \\ Malvern after ten years \\ Edited by Steven Pressman \\ 4 The End of Economics \\ Michael Perelman \\ 5 Probability in Economics \\ Omar F.Hamouda and Robin Rowley
}

6 Capital Controversy, Post Keynesian Economics and the History of Economics

Essays in honour of Geoff Harcourt, volume one

Edited by Philip Arestis, Gabriel Palma and Malcolm Sawyer

7 Markets, Unemployment and Economic Policy

Essays in honour of Geoff Harcourt, volume two

Edited by Philip Arestis, Gabriel Palma and Malcolm Sawyer

\section{Social Economy}

The logic of capitalist development

Clark Everling

9 New Keynesian Economics/Post Keynesian Alternatives

Edited by Roy J.Rotheim

10 The Representative Agent in Macroeconomics

James E.Hartley

11 Borderlands of Economics

Essays in honour of Daniel R.Fusfeld

Edited by Nahid Aslanbeigui and Young Back Choi

12 Value, Distribution and Capital 
Essays in honour of Pierangelo Garegnani

Edited by Gary Mongiovi and Fabio Petri

13 The Economics of Science

Methodology and epistemology as if economics really mattered James R.Wible

\section{Competitiveness, Localised Learning and Regional Development}

Specialisation and prosperity in small open economies

Peter Maskell, Heikki Eskelinen, Ingjaldur Hannibalsson, Anders Malmberg and Eirik Vatne

15 Labour Market Theory

A constructive reassessment Ben J.Fine

16 Women and European Employment

Jill Rubery, Mark Smith, Colette Fagan, Damian Grimshaw

17 Explorations in Economic Methodology

From Lakatos to empirical philosophy of science

Roger Backhouse

18 Subjectivity in Political Economy

Essays on wanting and choosing

David P.Levine

19 The Political Economy of Middle East Peace

The impact of competing trade agendas

Edited by J.W.Wright, Jr

20 The Active Consumer

Novelty and surprise in consumer choice

Edited by Marina Bianchi

21 Subjectivism and Economic Analysis

Essays in memory of Ludwig Lachmann

Edited by Roger Koppl and Gary Mongiovi

22 Themes in Post-Keynesian Economics

Essays in honour of Geoff Harcourt, volume three

Edited by Claudio Sardoni and Peter Kriesler

23 The Dynamics of Technological Knowledge

Cristiano Antonelli 


\section{The Political Economy of Diet, Health and Food Policy}

Ben J.Fine

\section{The End of Finance}

Capital market inflation, financial derivatives and pension fund capitalism Jan Toporowski

26 Political Economy and the New Capitalism

Edited by Jan Toporowski

27 Growth Theory

A philosophical perspective

Patricia Northover

28 The Political Economy of the Small Firm

Edited by Charlie Dannreuther

29 Hahn and Economic Methodology

Edited by Thomas Boylan and Paschal F.O'Gorman

30 Gender, Growth and Trade

The miracle economies of the postwar years

David Kucera

31 Normative Political Economy

Subjective freedom, the market and the state

David Levine

32 Economist with a Public Purpose

Essays in honour of John Kenneth Galbraith

Edited by Michael Keaney

33 Involuntary Unemployment

The elusive quest for a theory

Michel De Vroey

34 The Fundamental Institutions of Capitalism Ernesto Screpanti

35 Transcending Transaction

The search for self-generating markets

Alan Shipman

36 Power in Business and the State

An historical analysis of its concentration

Frank Bealey 


\section{Editing Economics}

Essays in honour of Mark Perlman

Hank Lim, Ungsuh K.Park and Geoff Harcourt

38 Money, Macroeconomics and Keynes

Essays in honour of Victoria Chick, volume 1

Philip Arestis, Meghnad Desai and Sheila Dow

39 Methodology, Microeconomics and Keynes

Essays in honour of Victoria Chick, volume 2

Philip Arestis, Meghnad Desai and Sheila Dow

40 Market Drive and Governance

Reexamining the rules for economic and commercial contest Ralf Boscheck

41 The Value of Marx

Political economy for contemporary capitalism

Alfredo Saad-Filho

42 Issues in Positive Political Economy

S.Mansoob Murshed

43 The Enigma of Globalisation

A journey to a new stage of capitalism

Robert Went

44 The Market

Equilibrium, stability, mythology

S.N.Afriat

45 The Political Economy of Rule Evasion and Policy Reform

Jim Leitzel

46 Unpaid Work and the Economy

Edited by Antonella Picchio

47 Distributional Justice

Theory and measurement

Hilde Bojer

48 Cognitive Developments in Economics

Edited by Salvatore Rizzello

49 Social Foundations of Markets, Money and Credit

Costas Lapavitsas 
50 Rethinking Capitalist Development

Essays on the economics of Josef Steindl

Edited by Tracy Mott and Nina Shapiro

51 An Evolutionary Approach to Social Welfare

Christian Sartorius

52 Kalecki's Economics Today

Edited by Zdzislaw L.Sadowski and Adam Szeworski

53 Fiscal Policy from Reagan to Blair

The Left veers Right

Ravi K.Roy and Arthur T.Denzau

54 The Cognitive Mechanics of Economic Development and Institutional Change

Bertin Martens

55 Individualism and the Social Order

The social element in liberal thought

Charles R.McCann, Jr

56 Affirmative Action in the United States and India

A comparative perspective

Thomas E.Weisskopf

57 Global Political Economy and the Wealth of Nations

Performance, institutions, problems and policies

Edited by Phillip Anthony O'Hara

58 Structural Economics

Thijs ten Raa

59 Macro economic Theory and Economic Policy

Essays in honour of Jean-Paul Fitoussi

Edited by K.Vela Velupillai

60 The Struggle Over Work

The "End of Work" and employment alternatives in post-industrial societies

Shaun Wilson

61 The Political Economy of Global Sporting Organisations John Forster and Nigel Pope

62 The Flawed Foundations of General Equilibrium Theory

Critical essays on economic theory

Frank Ackerman and Alejandro Nodal 
63 Uncertainty in Economic Theory

Essays in honor of David Schmeidler's 65th birthday

Edited by Itzhak Gilboa

64 The New Institutional Economics of Corruption

Edited by Johann Graf Lambsdorff, Markus Taube and Matthias Schramm

65 The Price Index and its Extension

A chapter in economic measurement

S.N.Afriat

66 Reduction, Rationality \& Game Theory in Marxian Economics Bruce Philp

67 Culture and Politics in Economic Development Volker Bornschier

68 Modern Applications of Austrian Thought

Edited by Jürgen G.Backhaus

69 Ordinary Choices

Individuals, incommensurability, and democracy

Robert Urquhart

70 The Labour Theory of Value

Peter C.Dooley

71 Capitalism

Victor D.Lippit

72 Macroeconomic Foundations of Macroeconomics Alvaro Cencini

73 Marx for the 21st Century

Edited by Hiroshi Uchida

74 Growth and Development in the Global Political Economy

Social structures of accumulation and modes of regulation

Phillip Anthony O'Hara 



\section{Growth and Development in the Global Political Economy}

Social structures of accumulation and modes of regulation

\section{Phillip Anthony O'Hara}

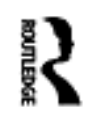

LONDON AND NEW YORK 
First published 2006 by Routledge 2 Park Square, Milton Park, Abingdon, Oxon OX14 4RN

Simultaneously published in the USA and Canada by Routledge 270 Madison Ave, New York, NY 10016

Routledge is an imprint of the Taylor \& Francis Group

This edition published in the Taylor \& Francis e-Library, 2005.

To purchase your own copy of this or any of Taylor \& Francis or Routledge's collection of thousands of eBooks please go to http://www.ebookstore.tandf.co.uk/.

$$
\text { (C) } 2006 \text { Phillip Anthony O’Hara }
$$

All rights reserved. No part of this book may be reprinted or reproduced or utilised in any form or by any electronic, mechanical, or other means, now known or hereafter invented, including photocopying and recording, or in any information storage or retrieval system, without permission in writing from the publishers.

British Library Cataloguing in Publication Data A catalogue record for this book is available from the British Library

Library of Congress Cataloging in Publication Data A catalog record for this book has been requested

ISBN 0-203-50838-6 Master e-book ISBN

ISBN 0-203-60038-X (Adobe e-Reader Format)

ISBN 0-415-29652-8 (Print Edition) 
This work is dedicated, first, to my very best teachers

Bill Winter Peter Fitzgerald Kong Sum Albert Schweinberger Herb Thompson Allen Oakley

Second to the memory (intellectual and/or personal) of some of the great long wave scholars of the past

Sam de Wolff Nikolai Kondratieff Ernest Mandel David M.Gordon

And third, to my favorite, grand political economists

Karl Marx Thorstein Veblen Joseph Schumpeter John Maynard Keynes 
. 


\section{Contents}

List of figures $\quad$ xvi

List of tables $\quad$ xviii

Preface $\quad$ xxi

Acknowledgments $\quad$ xxiv

1 Long waves of growth and development in the global political economy 1

2 Cultural contradictions of global capitalism 32

3 A global neoliberal social structure of accumulation? $\quad 47$

4 A transnational corporate social structure of accumulation? 66

5 A global money-trade-production mode of regulation? 86

6 A global unipolar, “antiterrorist” social structure of accumulation? 117

7 A regime of accumulation for sustainable productivity and demand? 136

8 A financial social structure of accumulation? 157

9 A family-community social structure of accumulation? 179

10 Post neoliberal governance for sustainable global growth and development 203

$\begin{array}{ll}\text { Index } & 238\end{array}$ 


\section{Figures}

1.1 Global System of Power and Accumulation 17

$\begin{array}{ll}1.2 \text { US System of Power and Accumulation } & 18\end{array}$

2.1 The dominant cultural contradictions of global capitalism 34

2.2 ISEW or GPI 1950-2000:4 nations 38

2.3 GDP excess over ISEW/GPI. 1950-2000:4 nations 38

3.1 World inequality, 1960-1999 55

5.1 The global money-trade-production MOR 87

5.2 The global money-trade-production SSA 88

5.3 The global circuit of social capital 89

$\begin{array}{ll}5.4 \text { Kaldorian dynamics of cumulative causation } & 91\end{array}$

6.1 Terrorism consequences-probability trade-off 122

6.2 Circular and cumulative network effects of terrorism 124

6.3 Contradictions of technology 125

7.1 Real GDP growth rate: decade annual averages: United States, 138 1950-2003 (seasonally adjusted)

7.2 S\&P500 price/earnings ratio: the United States, 1984-2004

7.3 Nasdaq-100 Index: the United States, 1993-2004 (1993=100) 148

8.1 Circuit of money capital 158 
8.2 The Chartel, finance-led accumulation regime and circuit

9.1 Systemic circuit of social capital

9.2 Simplified systemic circuit of social capital

9.3 Role of familial, social, and cultural factors in FCSSA formation 184

9.4 Relationship between trust, associations, and democracy

9.5 Contradictory stability-trust-inequality motion

9.6 Three mechanisms where inequality lowers growth 


\section{Tables}

1.1 Long waves for the major industrial nations 5

2.1 Four engines of global cultural growth, 1980-2001 35

2.2 Global investment, productivity, profit, and GDP, 1950s-2000s, 37 (decade annual averages)

2.3 Levels of trust: the world and various nations, percentage who 39 think people can be trusted, 1981, 1990, 1995-1997, 1999-2000

3.1 Growth of real GDP per capita in the global economy

3.2 Productivity growth in the manufacturing sector: 1960-1999 (annual rate of change)

3.3 Banking and currency crises in the world: 1945-1997 (21 nation 53 sample)

3.4 Domestic banking crises in the world: 1970s, 1980s, 1990s (percent of all crises during 1970-1999)

3.5 Inequality under neoliberal rule: Gini coefficient (1968-2002)

3.6 Real government gross fixed capital formation as percent of GDP, various OECD nations, 1960-2000

4.1 Unevenness in the global political economy, 1998-2000 average 70

4.2 Unstable FDI inflow, mergers and acquisitions, and 72 FDI/investment

4.3 After-tax rate of profit of the largest 500 US (TN) Corporations, 73 annual averages, decade by decade, 1954-2002 
4.4 Rate of profit for 500 largest global corporations, 1988-2002

4.5 Rate of profit for better performing sectors: global 500 largest $\quad 74$ firms, 1990-2002 (annual average rate)

4.6 Global investment, productivity, profit, and GDP, 1950s-2000s, 75 decade annual averages

4.7 Crowding in and out effects of FDI on investment, 1970-1996 77

4.8 Comparative levels of war, disease, instability and institutional $\quad 79$ development

4.9 Russia and Eastern Europe: economic performance, 1990, 1996, 80 2002

5.1 Global MOR/SSA functions, proxies, capitals, and contradictions 92

5.2 Labor productivity: global comparisons, 1960-2000 (GDP per 95 hour worked; annual average growth rates)

5.3 Demand proxies in the global economy, annual average rate of 96 growth

6.1 Worldwide fatalities of various sources of death per 100,000 population, 1983-1997

7.1 Average profit rate: the United States, 1950-2003

7.2 Annual average decade growth rates of GDP, productivity and related variables: the United States, 1954-2003

7.3 Demand components as a percentage of GDP: the United States, 144 1950-2003

7.4 Households: liabilities, consumption, and wealth: the United States, 1990-2000

8.1 Granger and $R^{2}$ relation between stock returns and production growth 
8.2 Malmquist productivity index for all US banks, 1980-1989 168

8.3 Productivity growth of the US BHCs, 1992-1997 (business 169 loans, consumer loans, securities, and off-balance sheet items)

8.4 Rate of return on assets “persistence” for US banks, 1971-1997 169

8.5 Percentage change in US bank fees, 1994-1999 171

9.1 Proxies for (un)familial (instability: the United States, 1950- 185 2000

9.2 Changes in the US family, 1950s-2000s

9.3 Trust in individuals and institutions, association and total social 188 capital, 1975-1994

9.4 Indicators of significance of structural factors in US economy

9.5 Impact of declining familial stability on economic performance 194

9.6 Influence of trust on investment and GDP, 1970-1992 


\section{Preface}

Developments over the past 20 or 30 years have seen the progression of neoliberal globalization. Financial markets have been deregulated, both domestic institutions and global arrangements. Foreign direct investment controls have mostly been dismantled to encourage international mergers, acquisitions, and productive capital. Imports and exports have been opened up to competition through a decline in tariffs and subsidies in many areas. Neoliberal policies of privatization, open markets, and flexibility became dominant globally through the 1980s and 1990s. The whole world, it seems, is seeking to become involved in shareholder value, conspicuous and privatized consumption, global financing, and business profit. The story that free-market economists are telling us is that this is the road to growth, development, happiness, and well-being.

But somehow the story gets tainted by real world processes that stain the Utopian expression of global harmony. We see around us environmental degradation, a decline in trust and fairness, problematic performance, financial and economic crises, terrorism and unilateral war-mongering, and rapid change and dislocation. Many wonder if neoliberal globalization is somehow linked to this decline in sustainability, sociality, stability, and performance, or if the association is mere coincidence. Could the Utopian vision portrayed in the textbooks and journals of orthodoxy be a caricature of the real thing, obstructed by a narrowness of vision and rose-colored glasses? Here I seek to find out the answers to these questions.

This book is guided by a holistic vision where global processes and problems are in large measure interconnected. The world and its constituents are linked causally in multiple ways. Luckily there are various traditions in political economy that help in understanding how these things are fused, through a series of networks and institutions. But they are not in the mainstream. The last thirty or forty years have seen a renaissance of interest in social and political economy. Veblenian institutionalists, evolutionary economists, post Keynesians, neo-Marxists, feminists, social economists, and global political economists have laid the groundwork for a thorough analysis of capitalism and its institutions. This current work utilizes themes in political economy to help comprehend recent trends in neoliberal globalization.

The notion of "contradiction" is an especially critical concept for understanding these connections and trends. This is because it posits the notion that one has to analyze both the positive and negative elements of a phenomenon before one can adequately scrutinize its operational dynamics. Capitalism is, for instance, the most revolutionary system ever seen on Earth, with a penchant for major technological innovations and rapid penetration of the global system, unearthing profitable opportunities irrespective of limits of a regulatory or cultural nature. Recently skills have been radically upgraded, foreign direct investment expanded (before collapsing in the early 2000s), fetters to expansion cast asunder, and nations and regions included in the global system of trade and money. This is the positive side that free-market economists have been singing the praises of for 300 years or more. 
But there is another side that is largely outside their ontology or methodology, although it often creeps in under the subtle guise of negative externalities and public goods. The very process of being revolutionary creates rapid change, so while some are moving up the ladder of skill development, many are left behind with the old ways and the inefficient methods. The latter will suffer due to a lack of employment, bankruptcy, or simply low income. Upgrading takes time and some have more capability to do it than others. Similarly, such rapid changes leave many nations relatively backward as they struggle to keep up with the rest of the world. Often a first mover advantage and cultural modernity are better than the disadvantage of not making the first effort at change. Uneven development is thus a necessary part of this motion, whether caused by colonial and imperial dislocation and oppression, the excessive pace of change, the hegemonic rules of the game, geographical and spatial factors, or a lack of social or human capital. The pace of change also puts people at risk of high levels of uncertainty and a lack of support mechanisms, as they feel that others are untrustworthy and that institutions are unhelpful. As resources are exploited the environment also takes a lashing through pollution, destruction of habitat, and potential climate change. Instability increases in a periodic fashion as hot capitals, foreign direct investment, and equity markets become highly volatile, while state supports decline.

Being able to see how these apparently quite different things-both positive and negative-are related requires having "a vision," a recognition of systemic processes, and a critical faculty that encourages an endogenous, open-systems view of the world. An exposure to political economy makes such a view second nature. While some orthodox economists see the creation of negative externalities as simply an unfortunate by-product of the inevitable, others of a heterodox persuasion see them as structural conditions of the system. Externalities such as financial instability, regional conflict, lack of trust, and environmental decline are endogenously institutionalized into the fabric of the system, especially in its neoliberal form. The two main theories utilized in this work-social structures of accumulation and modes of regulation-take a non-equilibrium, institutional, and endogenous view of long-term socioeconomic processes. Examining the historico-institutional evolution of capitalism in long-term motion is a way of understanding how we got to where we are and how we might change for the better.

Taking a holistic, endogenous, and open-systems approach requires that one differentiate between growth and institutional development, and also that one recognize growth and institutional development to be interrelated. Economic growth is usually looked upon as the rate of change of real GDP (gross domestic product) (per capita), which is linked to growth in productivity, consumption and investment, government spending, and net exports. Institutional development, on the other hand, relates to the building of progressive institutions for the promotion of human integrity and freedom, education, health, community networks, trust and governance, and productive relationships associated with industry and business. Institutional development implies an evolutionary transformation of human existence where institutions guide and manage change toward progressive values, habits, and organizational arrangements. It often implies the development of a social ethic and respect for other cultures, flora, and fauna.

The main hypothesis of this book is that growth and institutional development are indeed interrelated in that the creation of instrumentally progressive institutions is a preand co-requisite for long-term sustainable growth. The development of institutions for 
stability, conflict resolution, and performance is necessary for long-term sustainable growth where recessions are relatively mild and financial stability fairly strong. Without such institutions political economies tend to undergo long wave downswing, since social structures of accumulation or modes of regulation have not been suitably formed.

I have been helped by many people in trying to understand this process of institutional change. Very specific thanks are in the first endnote to most chapters. The most important stimulus to my work has been the numerous political and social economy associations and their wonderful members. Being able to attend gatherings of like-minded scholars, organized by the Association for Social Economics, the Association for Evolutionary Economics, the Union for Radical Political Economics, the European Association for Evolutionary Political Economy, the International Association for Feminist Economics, the Society for Heterodox Economics, the Eastern Economics Association, the History of Economic Thought Society of Australia, and the International Society for Ecological Economics, is a saving grace in a world otherwise dominated by orthodoxy. The editors of the main journals of political economy have been a great source of encouragement by their very presence and sense of camaraderie. Thanks especially go in this respect to Glen Atkinson, John Davis, Hazel Dayton Gunn, John King, Anne Mayhew, and Patrick Welch, among others.

I wish also to thank Doug Brown, Paul Dale Bush, Bill Dugger, Geoffrey Hodgson, Howard Sherman, Ron Stanfield, and Marc Tool who inspired me when it came to understanding institutions and evolutionary change. Jonathon Goldstein, Victor Lippit, Terry McDonough, Bruce Pietrykowski, Michael Reich, Robert Went and Behzad Yashmaian helped to sharpen my analysis of long waves. Jim Devine. Mike McLure, and Reynold Nesiba stimulated me intellectually on numerous critical issues. Rhoda O'Hara always showed an interest and provided encouragement. Rob Langham, along with Terry Clague, at Routledge among other things organized three reviews of this book, which included useful suggestions. I also wish to thank my colleagues at Curtin University, including Harry Bloch and Ian Kerr, for encouragement and assistance.

The challenge of global development is to create an institutionally rich analysis of the dominant tendencies of capitalism, and a post neoliberal form of governance to embed economy within society. Such a framework tries to balance the various conflicts between capital and labor, industry and finance, production and reproduction, terrorists and warmongers, and economy and environment. This requires an interdisciplinary view of the contradictory relationships underlying institutions and an evolutionary analysis of the system. Nothing less than thorough-going socioeconomic progress depends upon such a view and practice gaining momentum in the world. This book is a step in that direction.

Phil O’Hara

January 1, 2005

Global Political Economy Research Unit file://D:/input/2000dfbf/Philohara@runbox.com http://pohara.homestead.com/GPERU.html 


\section{Acknowledgments}

Parts of some of the chapters in this book have been published in the following journals and books:

Chapter 2, Journal of Economic Issues, Volume 38, Number 2, June 2004, pp. 413420, by special permission of the copyright holder, the Association for Evolutionary Economics.

Chapter 4, Review of Radical Political Economics, Volume 36, Number 3, Summer 2004, pp. 328-335, by special permission of the copyright holder, the Union for Radical Political Economics.

Chapter 5, Review of International Political Economy, Volume 10, Number 3, August 2003, pp. 481-519, by special permission of the copyright holder, Routledge and Taylor \& Francis.

Chapter 6, Global Political Economy and the Wealth of Nations: Performance, Institutions, Problems and Policies (ed. by P.A.O'Hara), 2004, by special permission of the copyright holder, Routledge and Taylor \& Francis.

Chapter 7, Review of Radical Political Economics, Volume 35, Number 1, Winter 2003, pp. 18-43, by special permission of the copyright holder, the Union for Radical Political Economics.

Chapter 8, Review of Radical Political Economics, Volume 34, Number 3, Summer 2002, pp. 295-301, by special permission of the copyright holder, the Union for Radical Political Economics.

Chapter 9, Forum for Social Economics, Volume 33, Number 2, 2004, pp. 51-80, by special permission of the copyright holder, the Association for Social Economics. 



\section{1 \\ Long waves of growth and development in the global political economy}

\section{Introduction—recent crises and instabilities}

The new millennium emerged amidst a whole series of global, regional, and national crises and emergencies. The threat of terrorism has struck at the heart of the social fabric of many nations, and some perceive it as the greatest ongoing threat to global security. The United States and some allies are said to be attempting to bully "rogue states" into submission, rather than going through more diplomatic channels, which is inciting retaliation in the Arab world. The Middle East continues to erupt in a series of hostilities between Palestine and Israel that seems never ending. Major nations such as Japan, the United States, and Germany were variously engulfed in financial slumps, deep recessions, and corporate fraud that eroded confidence before upswing emerged. Financial crises took hold of some nations in the "third world," such as in Latin America,- especially Argentina, Brazil, and Uruguay_which pushed the standard of living backwards. Some see the greatest crisis as emanating from the lack of investment in human and health resources to deal with the AIDS epidemic in Sub-Saharan Africa, which is spreading especially to some nations of Asia and the Caribbean. Meanwhile the threat of global warming and deforestation is impacting on the viability of agriculture and the survival of thousands of species, while the most powerful nation refuses to sign the Kyoto Protocol meant to reduce these problems. Uncertainties abound as the nations of the world struggle to adjust to a world of globalization, shareholder value, US dominance, and neoliberalism that leaves many of them open to the ravages of creative destruction, change, and transition.

Periods of protracted instability and crisis have been characteristic of human life since the beginning of recorded time. Sometimes these crises are very long and at other times they are shorter. But the fact of protracted periodic instability and uncertainty is a critical facet of humanity. Under capitalism these crises and instabilities generate their own inner motion, since creative destruction can lead to much global instability and tension. But where is this change and instability leading us? Is the global political economy-the nations of the world and global arrangements-moving into a new phase of durable prosperity, with the instabilities being transitional and moderate? Or are the periodic or structural crises imbedded in the institutions of capitalism? If "sustainable upswing" does emerge, will many people, nations, and regions be left behind while the privileged classes and areas benefit disproportionately from the innovations and changes?

Some authors think that recent innovations have speeded up the process of creative destruction and change, and have possibly shortened the periodicity of industrial waves and cycles (Dowling 2003). Such innovations have made interaction between people of different nations easier and reduced the barriers of spatial separation. However, even if 
the technological periodicities have been shortened, many other institutional lags and processes influence the overall length of the wave (Gordon 1998). For those who are in the vanguard of change the advantages of technological and institutional innovation are considerable. Classes and individuals who manage to succeed in business are subject to monetary, wealth, and quality of life benefits that they can pass on to their children and grandchildren. Businesses that succeed in the cutthroat world of competition and advertising are able to expand globally and transmit their talents to other organizations. Nations and continents that lead the rest of the world gain power in the global village and enhance the benefits to its peoples. For instance, parts of East and South-East Asia have expanded through the process of "take-off" and growth, despite some considerable hiccups in the process. ${ }^{1}$

On the other hand, despite short-run periodic upswings, the crises and cycles may be getting worse in terms of periodicity and amplitude, and the impact of change and instability more protracted. Some nations, classes, ethnic groups, and individuals do not have access to the benefits of these recent innovations, and the costs of change can be large. "Working people” in (especially Sub-Saharan) Africa, in particular, typically do not have access to the world wide web or many of the commodities that are common in advanced nations. Indeed, Sub-Saharan Africa has been undergoing a series of crisesAIDS, drought, famine, and war-that has left it behind other continents. Also, most nations over the past couple of decades have experienced more extreme inequality of income and wealth, leading many children to have a relative disadvantage in life due to factors beyond their control. For people at the bottom of the heap, acquiring skills and knowledge is a difficult practice, especially when change is so rapid and their individual, social, and material resources are meager. Having to leave home, change occupation, and learn new habits and practices are complex tasks fraught with problems and uncertainties, especially when there is a generalized lack of demand in the system. These long movements of change can upset the motion of societies and individuals that make up the world, leading to considerable adjustment costs and path-dependent irreversibilities.

It is difficult, though, to ascertain precisely how these long movements of change are working through to the quality of life and standard of living due to statistical problems and the uncertain nature of institutional change. Economists have long been gazing at the economic growth figures emanating from Gross Domestic Product (GDP), while historical-political economists and sociologists have been investigating the often more qualitative aspects of change and adjustment. GDP figures can move upward (often at a smaller rate), but the costs of adjustment can expand as well. Political scientists have continued to investigate changes in regimes and power structures through time that gives another dimension to change. A holistic perspective of what is happening eludes scholars intent on greater specialization. Yet a total view of these long movements becomes more necessary as change is more complex and cumulative.

Various traditions remain in the social sciences that encourage-even require-a holistic vision. But they are not in the mainstream. A general systems-view of contemporary capitalism situated in the long period can only really be developed in the tradition of political economy, a framework that almost died out in the late nineteenth century, but was kept breathing in the underground and recently has undergone somewhat of a renaissance. ${ }^{2}$ Political economy is an interdisciplinary study of the ways in which groups of people, nations, and cultures elk out their material (and often immaterial) life 
through historical time. It involves a critical analysis of the dynamics of socioeconomic systems as they evolve and become transformed. Power and cooperation are both required in the long-term reproduction of capitalism, and it is political economy that specializes in their long wave pattern of change. Being an interdisciplinary or transdisciplinary analysis of change, evolution, and metamorphosis, political economy is ideally suited to investigating complex global and national systems undergoing long wave crises and instability. ${ }^{3}$

One of the major hypotheses developed by political economists has been the notion of long waves of economic growth and development. This is the notion that capitalist economies (and possibly others) undergo long movements of upswing and downswing of the critical durable structures such as technologies, institutions, and relationships. Long waves are not deterministic in the sense of being necessarily precise in periodicity and amplitude and micro-specific in causality. For instance, waves do not have to accord with the typical 40-60-year pattern-20-30 years of upswing followed by a 20-30-year period of downswing. Also, while industrial technologies and GDP are part of the story, the whole story must include "core" institutions, relationships, and belief systems. Complexity and uneven development are essential parts of the motion. Also, due to statistical anomalies, the often qualitative nature of institutional change, and the potentially rapid pace of change, the results are tentative and subject to critical scrutiny. Much of what is presented here is qualitative, backed up with statistics where they are readily available. But changes can occur very quickly, in that a long wave downswing can rapidly move to upswing, while upswing can just as quickly move into downswing, pending the success or otherwise of governance processes and institutional change. Downswing can also become much more protracted since there is no necessary process leading to upswing, even though various responses can promote long wave recovery if they are successful. ${ }^{4}$

This book concentrates on long waves of the global political economy in the current environment. That is, I analyze the institutional dynamics of the global economy over the past few decades or more in the light of the requirements of long-term growth and development. The emphasis is placed on whether the contemporary operation of the global economy is consistent with long-term performance into the early decades of the twenty-first century. Special reference is given to the dominant neoliberal system of governance; the nature of terrorism and the war on terrorism; the functioning of transnational corporations (TNCs); the workings of the international monetary fund (IMF), the World Trade Organization (WTO), and the global system of productiondistribution; and the dynamics of the most critical nation - the United States-including its technological, financial, and family-community structures. Then Chapter 10 centers on the central governance issues and policies necessary for sustainable long-term performance in the world economy. In this light, the rest of this chapter provides an overview of the past history of long waves of growth and development, theories of long waves, and a summary of the chapters and argument that follow. 


\section{Long waves of capitalist growth and development}

"Long waves" is the notion that there are long-term dynamic phases in the evolution of capitalism, characterized by periods of relatively booming economic conditions followed by more recessed and unstable economic conditions. They are also known as Kondratieff waves or cycles, although most long wave scholars do not like to call them "cycles" because this implies rigid periodicity and amplitude as well as some essential endogenous processes leading to upswing and downswing. There are different waves examined by scholars, some with a periodicity of hundreds of years (see Wallerstein 1974, 1980, 1989), some of thousands of years (Gunder Frank and Barry K.Gills 2000), and the ones concentrated on in this book of 40-60 years.

Typically, during the first half of each 40-60-year wave, institutional and technological innovations pave the way for 2 or 3 decades (or more) of quite strong economic growth and development, since recessions and financial instabilities are usually relatively moderate. For instance, this was the case for most advanced nations during the postwar boom of the late 1940s through to the early 1970s. But eventually the institutional and technological innovations became exhausted as the contradictions within the system heightened, which led to 2 or 3 decades (or more) of less impressive growth and development as periodic recessions and financial instabilities are usually quite intense. This downswing occurred for most nations of the world (except many in (South)East Asia) during the mid-1970s through to the 1990s or 2000s.

In principle, it might be possible for long wave downswing to be averted if economic actors and governance practitioners can foresee the underlying problems before they become manifest, and then instigate certain changes that are successfully implemented and institutionalized. In practice, this is unlikely (but not impossible), since actors and forces usually cannot see trends before they are well in place; often they cannot agree on required changes due to incessant conflict and power differentials; and institutional and technological changes usually require considerable time to become activated and habitual. Long wave upswing, therefore, is generally followed by a long wave downswing, usually lasting two or three decades (or even longer), in which the rate of profit and accumulation decline (on average) for a considerable period since deep recessions and financial instabilities become more intense. During such downswings policies and practices are activated to stimulate renewal and often these succeed through institutional and technological changes.

Long wave scholars mostly agree on the past experience of periodicity in relation to the evolutionary tendencies of capitalism and the record of recessions/ depressions and financial crises over successive long waves. They agree that the major industrial nations of capitalism have been undergoing a series of non-deterministic phases of evolution since at least the 1780s when "liberal-industrial" capitalism began to emerge. Differences exist between nations because of uneven development and center-periphery relationships, since through successive long waves changes occur between nations and regions as some rise and others fall. Indeed, in some large measure long wave upswing occurs for those nations that bind together and control the prevailing structures of production, finance, 
trade, and military. Usually a nation or group of nations set(s) the pattern of institutions and power relations and thereby functions at the apex of the global system.

For instance, during the late 1940s through to the early 1970s, the Western nations and Japan were led by the United States into a golden age of growth and development. They were subject to competitive political struggle vis-à-vis the "socialist" block, which also underwent in most cases a positive period of renewal. But especially Africa, much of Asia, and also Latin America were not really included in these structures of association and culture. As relative downswing emerged from the mid-1970s through to the 1990s or 2000s, the West declined relative to Asia, while Africa and Latin America also suffered; as did the "socialist" block of Eastern Europe, which eventually dissolved (Maddison 2000: ch. 3). These differences between nations or regions are really quite critical to long wave analysis.

Nevertheless, looking at the question generally, a summary of this broadly agreed periodicity of long waves for the major industrial economies (or for the global aggregate; see van Duijn $1983^{5}$ ) is provided in Table 1.1. There have thus far been four long waves in the recent history of capitalism, the first (upswing) being initiated in the environment of the French and American revolutions during the 1780s and 1790s, the second during the gold rushes of the 1850s, the third around the time of the first phase of globalization in the mid-late 1890s, the fourth after the second world war in the late 1940s and 1950s, and a fifth possible upswing at the beginning of the twenty-first century. The first downwave emerged after 1815 leading up to and including the European revolutions of 1830 and 1848, the second during the "long contraction" of the 1870s-1890s, the third including the period from the First World War through to the Second World War, and the fourth during the 1970s-1990s/2000s. Long wave upswings tend to generate periodic minor recessions and a relative absence of banking crises, while downswings are characterized by periodic deep recessions/depressions every decade or so and a series of major financial crises as well as debt crises in the periphery.

The basic idea behind long waves is that the durable structures of the economy evolve over time in relatively complex patterns of development and demise.

\section{Table 1.1 Long waves for the major industrial nations}

\begin{tabular}{|c|c|c|c|c|c|c|}
\hline & Date & Long wave & Upswing & Downswing & $\begin{array}{c}\text { Technology } \\
\text { style }\end{array}$ & Institutions \\
\hline $\begin{array}{l}\text { Long } \\
\text { wave } \\
1\end{array}$ & $\begin{array}{l}1780 s- \\
1840 s\end{array}$ & $\begin{array}{l}\text { Industrial } \\
\text { revolution }\end{array}$ & $\begin{array}{l}\text { 1780s- } \\
1810 s\end{array}$ & $1810 s-1840 s$ & $\begin{array}{l}\text { Cotton textiles; } \\
\text { iron and steam } \\
\text { power; furnace } \\
\text { iron smelting; } \\
\text { crop rotation }\end{array}$ & $\begin{array}{l}\text { Age of revolutions, } \\
\text { simple control of } \\
\text { labor, nationalism, } \\
\text { entrepreneurial } \\
\text { business }\end{array}$ \\
\hline $\begin{array}{l}\text { Long } \\
\text { wave } \\
2\end{array}$ & $\begin{array}{l}1850 s- \\
1890 s\end{array}$ & $\begin{array}{l}\text { Large-scale } \\
\text { industry }\end{array}$ & $\begin{array}{l}1850- \\
1870 s\end{array}$ & 1870s-1890s & $\begin{array}{l}\text { Steam engine, } \\
\text { railways, gold }\end{array}$ & $\begin{array}{l}\text { British hegemony, } \\
\text { joint stock } \\
\text { company, from } \\
\text { simple to technical } \\
\text { labor control }\end{array}$ \\
\hline I.ong & $1890 \mathrm{~s}-$ & Finance & $1890 \mathrm{~s}-$ & 1910s-1940s & F.lectricitv and & Finance canital. \\
\hline
\end{tabular}




\begin{tabular}{|c|c|c|c|c|c|c|}
\hline $\begin{array}{l}\text { wave } \\
3\end{array}$ & $1940 \mathrm{~s}$ & $\begin{array}{l}\text { capital and } \\
\text { imperialism }\end{array}$ & $1910 \mathrm{~s}$ & & chemicals & $\begin{array}{l}\text { imperialism, big } \\
\text { business, modern } \\
\text { party system, } \\
\text { technical labor } \\
\text { control }\end{array}$ \\
\hline $\begin{array}{l}\text { Long } \\
\text { wave } \\
4\end{array}$ & $\begin{array}{l}1940 s- \\
1990 s / \\
2000 s\end{array}$ & $\begin{array}{l}\text { Postwar global } \\
\text { Fordism }\end{array}$ & $\begin{array}{l}1940 s- \\
1970 s\end{array}$ & $\begin{array}{l}1970 s- \\
1990 s / 2000 s\end{array}$ & $\begin{array}{l}\text { Internal } \\
\text { combustion } \\
\text { engine, assembly } \\
\text { lines, oil }\end{array}$ & $\begin{array}{l}\text { Fordism, } \\
\text { Keynesian-welfare } \\
\text { state, US } \\
\text { hegemony, } \\
\text { bureaucratic labor } \\
\text { control }\end{array}$ \\
\hline $\begin{array}{l}\text { Long } \\
\text { wave } \\
5 ?\end{array}$ & $\begin{array}{l}\text { 2000s- } \\
\text { 2040s? }\end{array}$ & $\begin{array}{l}\text { Globalization } \\
\text { and } \\
\text { information } \\
\text { technology? }\end{array}$ & $\begin{array}{l}\text { 2000s- } \\
\text { 2020s? }\end{array}$ & $\begin{array}{l}\text { 2020s- } \\
\text { 2040s? }\end{array}$ & $\begin{array}{l}\text { Electronics, } \\
\text { biotechnology? }\end{array}$ & $\begin{array}{l}\text { Globalization, } \\
\text { deregulation, } \\
\text { neoliberalism? or: } \\
\text { embedded } \\
\text { liberalism, social } \\
\text { capital, and balance } \\
\text { of industry and } \\
\text { finance? }\end{array}$ \\
\hline
\end{tabular}

Some theorists concentrate on the life of durable fixed capital, others on technology, still others on changing center-periphery relations, while another group concentrates on institutions and social relations. Some combine aspects of all of these for a more holistic view of the evolutionary tendencies of capitalism. The holistic approach is becoming the norm among wave scholars as the evidence tends to support a multi-factor perspective. ${ }^{6}$ Also there is less emphasis on strict periodicity, amplitude, and regularity as scholars become more interested in the complexity of historical change rather than deterministic views of reality.

The four long waves that have occurred in the recent history of capitalism are delineated briefly in the following section. But the reader should keep in mind that this is a brief overview and the main objective of this book is to explore the nature of the recent and more contemporary record, especially in relation to whether we are currently seeing a long wave upswing or a continuation of downswing or something in between (more complex) in the global political economy. The given overview seeks to set the scene for the analysis of the current situation throughout the rest of the book.

(a) Industrial revolution: 1780s-1840s The first modern wave was during the 1780s1840s: the "age of revolution" as Eric Hobsbawm (1962) has called it. The French "political revolution" helped to initiate historico-political forces in many nations for the demise of the old order, such as the landed gentry, privileged nobility, and monarchy. Linked to this are the values and institutions associated with parliamentary democracy, freedom of expression, and a relative diminution of certain class privileges. Before long much of the world had attempted to transform their structures of power and prestige, or at least evolve along the road of social and political change. Political changes in France, the United Kingdom, and the United States then filtered through to many other areas. These changes were often painful and uneven, but eventually they established the foundations of a liberal capitalist system. 
The English were at the forefront of the economic or "industrial revolution." The leading technology of the revolution was based on cotton textiles, new methods of crop rotation, the spinning mill, the power loom, iron and steam power, steam blasting for smelting iron, and the reverberating furnace (Mager 1987:75). Many key changes were institutional, through the gradual creation of an industrial society based on wage labor, commodity production, and a class of industrial entrepreneurs in the agricultural, mining, and manufacturing sectors. Historical forces began to subject labor to "simple forms of control" by smallscale entrepreneurs in many industries of the industrial world. ${ }^{7}$

These political and economic revolutions were important to the eventual rise to power of the liberal bourgeoisie, and a class of labor that was free of the institutional constraints of the past, as well as an expansion of economic activity, investment, and accumulation. The period 1790-1815 was not only characterized by continual war in Europe, but also by an expansion of productivity, growth, as well as social overhead capital such as roads, waterways, and shipping. Textiles were the dominant consumer good in the leading nation (Britain). However, from about 1815 onwards economic activity, profit, and wages declined as the institutional contradictions of the system began to manifest themselves. Ironically the downswing coincided with the start of British hegemonic dominance (which lasted until the 1880s). ${ }^{8}$ High levels of competition and industrial advance led to declining prices, deflation, and periodic deep recession. Things got worse in the 1830s and 1840s. As Hobsbawm said:

by the 1830s and early 1840s [there were] major problems of growth, not to mention revolutionary unrest unparalleled in any other period of British history. This first general stumbling of the industrial capitalist economy is reflected in a marked slowing down in the growth, perhaps even in a decline, in the British national income...Nor was this first general capitalist crisis a purely British phenomenon.

Hence the "first Kondratieff upswing" made way for downswing by the 1810s and 1820s as the rate of profit failed to sustain sufficient investment in capital, and financial crises became worse, culminating in the depression of the 1830s and 1840s (depressions tend to occur near the end of long wave downswings). As the conditions of the working class and peasantry deteriorated in many nations, revolutions emerged in Europe during 1830 and 1848, and while most of them failed in many respects, they did help the cause of social, political and economic change in the longer-term horizon.

(b) Large-scale industry: 1850s-1890s Even during the downswing of 1815-1848, though, changes evolved that eventually helped to propel a long wave upswing. As new institutions, technologies, and products were created a new long wave had emerged by around 1850, with upswing during the 1850s-1870s and downswing during the 1870s1890s. British hegemony and free trade led the world economy, and the joint stock company enabled industrial expansion and scale. Major developments were in railways, machine-made steam engines, and gold discoveries in California and Australia, and while Britain was expanding industrially many other nations were going through an agricultural upswing. 
Much of Europe and many of the "White" settler colonies such as the United States and Australia joined Britain in benefiting from the "second Kondratieff upswing" when the "Age of Capital" (as Hobsbawm 1975 called it) is said to have gone through a "takeoff” in many nations, while Britain underwent a new phase of renewal. ${ }^{9}$ Booming primary product prices played a role, immigration and foreign investment stimulated long lags of domestic growth, while railways, shipping, and roads helped market expansion and the penetration of capital into more areas. Of critical importance to the building of a network of production and distribution relations was the railway system (and the associated electric telegraph) in most advanced nations, since "it was the railways that made it possible to diffuse a new technological style based on coal, iron, and the steam engine....as the 'carrier branch' of the second Kondratieff [wave]" (Freeman and Louca 2002:198). As upswing progressed, the mining and manufacturing sectors rose to new heights. In the production process of some advanced nations, "simple control" of labor gradually gave way to "technical control" of labor through the machinery of the production process (Gordon et al. 1982), while in many less advanced nations simple control was deepening in the entrepreneurial firms.

Historical evolution was uneven and contradictory as institutional problems emerged through the 1870s and the "great contraction" continued until the mid-1890s in most nations. ${ }^{10}$ Large-scale production was achieved in core areas and sectors of the world system by the time of the late 1870s (Veblen 1904, 1923), which led to periodic instability and overproduction as investment became volatile. Overproduction and underconsumption resulted also from excess competition through depleted profitability in the core sectors of industry. The low profits led to financial instability and periodic collapse, with a relative deterioration in economic activity throughout most regions of the world. However, it was not only industry that suffered, since "[a]griculture was the most spectacular victim of this decline in profits," which led to "electoral agitation" and "rebellion," including the "peasant revolts...between 1879 and 1894 in Ireland, Spain, Sicily, and Rumania” (Hobsbawm 1987:36).

The great contraction, again, was unevenly spread through the world system, as the old industrial areas of England and France declined relative to those of Germany and the United States (Beaud 1984:124-125). From the 1880s onward there was no hegemonic nation to provide leadership and domination that might have propelled further systemic turnover and profit, although Britain was still ahead militarily and economically until the turn of the century (Goldstein 1988:330). From relative instability, class conflict intensified, many workers were replaced by technology (Gordon et al. 1982:97), but out of this the labor movement began to emerge in most nations, and real wages became more favorable for workers in the West into the 1880s and especially 1890s (due mainly to deflation). However, Beverly Silver (1992) doubts that a general theory of class struggle can be linked to long waves in any systematic sense, since workers are unlikely to become more unified during every downswing.

(c) Financial and oligopoly capitalism: 1890s-1930s Capital and the state responded to the low profitability of the late 1800s and especially 1890s through the organization of mergers, greater concentration of industry, financial innovations, and the global expansion of markets and colonies (Veblen 1923). Big financial and commercial capitalists began to dominate manufacturing and agricultural capital in the core nations. Finance capital began to dominate industry. Many nations vied for control of colonies in 
the periphery as globalization and imperialism expanded during the earlier years of this wave (Hobsbawm 1987). The decline of British hegemony led to an upsurge in imperial expansion by many Western powers, which did not generally advance living standards for people in Africa, Asia, and Latin America (Maddison 2001: chs 1 and 2). Advanced nations sought overseas markets for their goods and services as a solution to the limits of internal growth. Electricity and chemicals were leading sectors, and labor unions continued to emerge in the new industrial landscape of many nations. These multiple forces helped to propel a "third Kondratieff upswing" which emerged just before the turn of the twentieth century, and was known as the era of financial oligopoly capitalism and imperialism. The period 1897-1914 was a very profitable period in the advanced nations of the world (Poletayev 1992).

The demise of British hegemony around the 1880s led the way to a possible alternative hegemon. This power vacuum stimulated heightened global conflict, especially through German expansionism and the ensuing First World War which upset the dynamics of long wave upswing. A temporary recovery emerged in the early-mid1920s, but it was soon to coalesce into the greatest economic crisis of the modern world, the Great Depression of the 1930s, which saw the effects of underconsumption and financial instability push unemployment to record heights of around 30 percent in many nations. The depression and the Second World War during 1929-1945 was the culmination of the "third Kondratieff downswing."

Indeed, the period from 1914 through to 1945 was one of continual crisis and instability, when no hegemonic power was available to promote global accord and stability and when many nations were vying for global supremacy and power through war, trade, and diplomacy. The era of free trade and globalization characteristic of the period from 1870 to 1914 gave way to inward looking and protectionist policies over the next 30 years. According to Karl Polanyi (1944), these protective responses were due to the need for capitalist economies to cushion the impact of a market economy that destroys societal bonds and social safety nets. Missing from market relations were sufficient global stability, sufficient internal demand, and sufficient power of industry over finance. These three barriers to capital helped to generate the Great Depression as the Taylor production system failed to sustain aggregate demand, ${ }^{11}$ stock market instability led to speculative bubbles and crash, and unstable global regimes led to lack of cooperation and nationalist excesses.

The lessons from the Great Depression, war and their aftermath were that government spending and policy could stabilize capitalism, liberal democracy could (along with "socialism”) defeat fascism and still provide a stable system of global (US) hegemony, and enhanced worker conditions and wages could solve the remaining problems of the Fordist system of production.

(d) Fordist-Keynesian capitalism transition to neoliberal-globalization: 1940s-2000s The Polanyian problem of the disembedded economy was to some extent solved for advanced nations during and after the Second World War through the provision of institutional supports for higher productivity, greater demand, and a resolution of many of the conflicts of the earlier downswing. This fourth wave, during the 1940s-2000s, is known as the postwar era of Fordism and the Keynesian-welfare state. The 1939-1945 World War settled the question of global power as US hegemony became well established along with, in the 1950s and 1960s, a relative (perceived) balance of military 
power (and Mutually Assured Destruction) between the West and the Communist Block. Social, political, and economic stability set in as Marshall aid helped to promote (capitalist) reconstruction in Western Europe and a series of global and domestic institutions and technologies were set in place during the late 1940s and 1950s.

For advanced nations, this was the age of the internal combustion engine, semiautomatic assembly line processes, segmentation of the labor market, the welfare state, a capital-labor accord, US hegemony, and the stability of the patriarchal family (see O’Hara 2000). "Global Fordism,” as it was called, led to a unified system of technology and institutions along with two decades of strong growth and development during the "fourth Kondratieff upswing" of the 1950s, 1960s, and early 1970s. For the nations of the United States, Europe, and parts of Oceania this long boom or "Golden Age" as it has been called, was typified by large-scale production and mass consumption. Some of the most populous areas of the world, however, did not benefit much from the long wave upswing (parts of Asia, most of Africa, and parts of Latin America) since the Golden Age was designed to benefit mainly the advanced capitalist nations.

After 20 or 25 years of upswing, a Kondratieff downswing emerged for most nations as the contradictions within the institutions and technologies began to manifest into the early-mid-1970s. The stability of US hegemony and the "capital-labor accord" was questioned as the West lost the Vietnam War, relative US productivity declined, and workers and citizens groups helped to reduce the power of capital. The technologies of the golden age matured as consumers became saturated with durables in the advanced nations. The Keynesian-welfare state was said to hinder business through a host of regulations, red tape, and financial irregularities. The regulated financial system apparently became obsolete as innovations reduced distinctions between institutions and questioned established practices. And the family went into disarray as the sexual revolution and changing social practices led to greater geographical mobility, social flexibility, and instability. Uncertainty abounded in the early-mid-1970s as the profit rate declined through greater wage, raw material, fiscal, and financial pressures. Four major recessions emerged in most advanced nations, during the mid-1970s, the early 1980s, the early 1990s, and the early 2000s. A major depression has not yet emerged, perhaps because of lender of last resort facilities and big government (Minsky 1982). Some call this downswing a “silent depression” (see Bowles et al. 1990; O’Hara 2000).

Early on in the downswing, however, efforts were made to regenerate performance. During the 1980s, the Thatcher and Reagan revolution spread neoliberalism and globalization through the advanced nations - and later elsewhere-leading to attempts at greater privatization, reduced state spending, and reduced red tape and taxation (for the rich and corporations). Attempts were made to reduce the power of labor, promote finance capital, and advance the cause of free trade in the world economy. Many nations of East Asia seized the opportunity to replace advanced nations as the main suppliers of mass produced goods as wages rose and productivity declined in the West. And as long wave downswing also impacted on Russia and its satellites, market capitalism was introduced "cold turkey" into the Eastern Block with some disappointing results in the first decade and a half (especially for Russia and the Ukraine). During the 1990s and early 2000s, financial and economic instability reemerged as a critical problem globally, in the West and also in many other areas (including Asia-especially Japan and SouthEast Asia-and parts of Latin America). During the 1970s-2000s Africa experienced one 
of its worse records of growth and development (Maddison 2000:126; World Bank 2004).

(e) Neoliberalism and globalization? 2000s-2050s? This study, then, specifically, examines the pattern of long wave motion of the United States and world economies around the time of the commencement of the twenty-first century. Some scholars argue that globalization, neoliberalism, and open markets had already led to long wave upswing during the 1990s, or alternatively is leading the way during the early 2000s to a durable expansion of the circuit of economic relations. It is said by some that the economies of Asia and Eastern Europe provide the system with an expanding market; new technologies enhance productivity and supply, while corporate developments and innovative competition enable sustainable profitability. While contradictions exist, they are said not to be extreme, and durable upswing is propelling a new long wave (upswing). These optimistic conclusions are, for instance, variously proposed by Victor Lippit (1997), Behzad Yaghmaian (1998), and Hossein-Zadeh and Gabb (2000).

Others argue that neoliberalism and related institutions have critical contradictions that are strong enough (so far) to prevent such sustainable upswing. These contradictions are variously said to include the onset of social and financial instability, which reduces trust and industry; lack of effective demand and technological anomalies, which inhibit sustainable productivity; excess competition, which reduces sustainable profitability; and heightened global tension, which expands uncertainty. We are thus still in the "fourth Kondratieff downswing” as. for instance, argued by Fred Moseley (1999), Robert Brenner (1998), Michel Aglietta (1998), and Phillip O’Hara (2000, 2004). The institutions, relationships, and practices of contemporary capitalism are thus said to be fraught with problems that generally inhibit positive long-term reproduction of the system. Neoliberalism — and to some degree globalization — has had a negative impact on long-term social and economic performance.

The big question is thus whether we are currently still in a long wave downswing or whether sustained upswing has commenced. It is argued in this book that capitalism is still in a long wave downswing, although in every wave there are patterns of uneven development, the principal one at present being certain East Asian economies rising (despite instabilities in the late 1990s) while the West and most other economies are declining in relative terms. It is critical to distinguish, as Schumpeter (1939) and others have, between short cycles and long waves. The short cycles tend to occur in patterns of 3-5 and 8-11 years each. The long waves are variable, but often in the form of 40-60 years. Many scholars confuse an 8-11-year cycle upswing with a long wave upswing, such as during the mid-late-1990s. Empirical analysis reveals that it is possible to be in a short-cycle boom (such as the late 1990s) yet simultaneously be in a long wave downswing. This is because short-run growth may be occurring while long-term conditions are weak. During the 1990s, for instance, a boom eventually emerged in many nations that was dominated by speculative bubbles, euphoria, and new technology sectors. High growth was possible, but not sustainable upswing, due to weak underlying conditions in the institutions. This book concentrates on the "fundamental" conditions within the institutions. Thus, during the long wave downswing of the 1970s-2000s, every 8-11 years or so financial instability becomes extreme and eventually deep recession emerges, usually at the global level, although there are always national peculiarities that differ from the average. 


\section{Theories of long wave dynamics}

Long wave theory and empirical analysis have advanced considerably since the earlier efforts of Hyde Clarke (1847), Mikhail Tugan-Baranowski (1894), "Parvus” (Alexander Helphand 1901), J.van Gelderen (1913), Marcel Lenoir (1913), Nikolai Kondratieff et al. (1928), Sam de Wolff (1929), and Joseph Schumpeter (1939). Long wave scholars have consistently been committed to the development of a dynamic, evolutionary theory of "economic life" (as Kondratieff called it). The theoretical debate up until the 1940s centered on questions of whether waves were propelled by the life of durable fixed capital-for example, machinery and factories-(de Wolff and Kondratieff), or innovation (Schumpeter), or prices (Lenoir), or whether they are broad, less deterministic evolutionary forces of considerable variation and metamorphosis comprising endogenous and exogenous factors (Parvus, van Gelderen, and Leon Trotsky).

Nikolai Kondratieff's empirical analysis was one of the most advanced of the early generations of long wave scholars. He developed five main empirical hypotheses, including the role of bunching of inventions and innovations, expansion of the world market, agricultural prices, gold, and wars and revolutions. These hypotheses have been a constant source of research even up to the present time (see Mager 1987). Kondratieff later posited an endogenous process (following Marx on short cycles) concerning the life of durable fixed capital, which even today has an exponent in the form of the work of Jay Forrester. However, this explanation, especially in the form taken by Kondratieff, is too technical and limited an explanation of long waves and does not adequately include the institutional and technological environment.

Joseph Schumpeter's theory of innovation, development and cycles was influenced by Kondratieff. His brilliant Theory of Economic Development (1911) was a general theory of innovation and cycles. It was not until Business Cycles (1939) emerged that long waves were given a specific place in his analysis for "marshalling [the] facts" (Schumpeter 1939:170). He employed a method of successive approximation that started with steady state equilibrium, then introduced development through a "swarm" of innovation, which creates surplus value and low amplitude cycles (recovery and recession), and then introduced speculation, adapted credit for unproductive loans or general accumulation (as well as innovation), which increases the amplitude to four phases: boom, recession, depression, and recovery (in that order). The length of the cycle depended on the durability of the innovations and the lags involved. Schumpeter made the simplifying assumption that there were three cycles: Kitchin cycle (3-5 years), Juglar cycle (7-11 years), and Kondratieff cycles (long waves) (35-60 years); and that there are three Kitchins for every Juglar and six Juglars for every Kondratieff. He recognized that capitalism is inherently unstable, and help may be needed by the state if the downswing involves entrenched negative expectations about the future (Schumpeter 1939: vi, 155).

Schumpeter was criticized on many counts: for having a long entrepreneur (by Paul Sweezy 1943), rather than a modern capitalist corporation-something he rectified somewhat (Schumpeter 1950). He was also criticized for abstracting from Keynesian employment theory (by Oskar Lange 1940), for not "proving" the notion of the "swarming of endogenous innovation" (Simon Kuznets 1940), for not specifying the nature of the reference cycle, and so on (see Garvy 1943; Kleinknecht 1987). But despite these criticisms, in the 1950s business cycles, waves and long swings were popular topics 
in the textbooks and journals, analyzed by scholars such as Walt Whitman Rostow, Alvin Hansen, and Kuznets. However, into the 1960s, traditional Keynesian employment theory and policy became more dominant, and long-term analyses of the evolution and cyclical nature of capitalism were less common. But from the late 1960s and early 1970s onwards, all this changed as the capitalist system underwent major instability and crises, and a revival of political economy developed into the 1960s-2000s. Neo-Schumpeterian scholars were in the forefront of this revival and the significance of Schumpeter has thus heightened of late. ${ }^{12}$

Ernest Mandel (1964) in the Socialist Register was one of the first to see the forces of transformation and disarray emerging in the world economy during the fourth Kondratieff wave of the postwar era. In Late Capitalism (1975) and later Long Waves of Capitalist Development (1980; second edition 1995) he went on to develop his theory of the long wave, which was a fusion of the earlier work of Trotsky, Kondratieff, and Schumpeter. His theory was based on changes in the rate of profit affecting investment and growth. Mandel argued that the upswing is not inevitable but may result from a combination of forces influencing the rate of profit: power and struggle, competition, war, and revolution, and which become manifested as new sectors and technologies (following the spirit of van Gelderen and Trotsky). The downswing of the wave is endogenously driven by a rise in the organic composition of capital as the capitalist process itself results in a falling rate of profit (following Marx's analysis to some degree). His explanation for the upswing has much merit, but the emphasis on the organic composition of capital propelling downswing is exaggerated. ${ }^{13}$

Many other theories (re-)surfaced in the 1960s and 1970s. For instance, drawing from one of Kondratieff's main hypotheses, Rostow in a number of works continued to argue (as he did in the 1950s) that the relative price of agricultural and manufacturing goods is the critical phenomenon. In his many books and articles he examined sectors and markets in the long wave process. His emphasis on real historical time is commendable. On the other hand, his theory has produced of late a peculiar periodicity: 1951-1972 is a downswing, 1972 onwards is an upswing (Rostow 1978, 1980). The real problem for Rostow is his concentration on the primary goods sector and relative prices; he has not adequately adapted his analysis to the industrial world and the general institutional environment.

Jay Forrester resurrected de Wolff and Kondratieff's theory of durable fixed capital during the 1970s in the Systems Dynamic National Model Project at MIT. In this "capital investment" approach, long waves are generated by long-term overexpansion and decline associated with the capital goods sector. There are three sectors in his model: consumer goods, capital goods which produce capital goods, and capital goods which produce consumer goods. An upswing is linked to greater consumer demand propelling complex long-lag expansions of the capital goods sector. With the "bootstraps mechanism" the capital goods sector "pulls itself up by its own bootstraps" (by producing more of itself) before it can satisfy consumer demand. Longer lags are introduced with price, credit, and innovation feedbacks. Overproduction from the early 1970s, for instance, in industries such as shipbuilding, factories, warehouses, and motor vehicles, was due to the optimistic expectations that arose during expansion, beyond what is justified on the basis of marginal productivity. The economy operates well below average capacity for 20 or 30 years as most of the lags become reversed. Many modern political economists would see 
this theory as being rather deterministic; however, they are likely to agree that fixed capital and the lags are an important part of a wider story of growth and transformation.

There are four main contemporary political economy approaches to long waves. ${ }^{14}$ They are based on historical time, institutions and/or technology, human relationships, circular and cumulative causation, and long-term evolution and transformation. First, World-Systems theorists have for years examined the unequal changes and transformations involved in core-periphery relations over long real time. Many different periodicities of long-term motion (50, 100, 300 years and longer waves) have been studied. Immanuel Wallerstein, Andre Gunder Frank, Giovanni Arrighi, Samir Amin, and their colleagues have related long waves and longer movements to transformations from Dutch to British to US hegemony and beyond, complex changes in center-periphery relations in the World System, and institutional evolution linked to third world debt, the reemergence of Asia, industrial relations, sectoral transformation, family relations, and many other areas. Much of this work emanates from the Fernand Braudel Center at Binghamton in New York State (see the journal called Review from this Center and the web-based Journal of World-Systems Analysis from the Department of Sociology at the University of California, Riverside). ${ }^{15}$

Second, in Europe, Gerhard Mensch led the modern Schumpeterian trend in Stalemate in Technology (1979), which developed a metamorphosis model of sudden sectoral transformations. Christopher Freeman in his monographs and edited books has done much to refine and develop work on technology, innovation, evolution, and cycles, in particular integrating this with institutional analysis (see Freeman et al. 1982). Countless other analysts continue to take Schumpeter as a point of departure in their scrutiny of long wave motion (e.g. Kleinknecht 1987). Themes examined include the relationship between innovation and economic activity, the need for the state to facilitate profitability during long downswings through technology and other policies, leading sector analysis, and the role of competition and corporate dynamics. The relationship between technology, institutions, and ideology has become an important part of this work (Freeman and Louca 2002).

Third, Carlota Perez (1985) and Andrew Tylecote (1992) extended this Schumpeterian influence to issues taken seriously by the "regulation approach" (originating in France), which studies the dialectic between technology and institutions. The regulation approach itself developed through the work of (especially) Michel Aglietta, Robert Boyer, Alain Lipietz, and Bob Jessop. ${ }^{16}$ In the "standard" regulation approach mostly followed in this book, long wave upswings take the form of an expanding mode of regulation (MOR), which includes a regime of accumulation and a series of structural forms. The regime of accumulation includes a technology style (for potential productivity) and a mode of consumption and distribution (for demand), while the structural forms include a suitable array of institutions associated with money, competition, trade, and world economy. Long wave upswings develop when the technology style and mode of consumption are positive and in dynamic rapport with each other, and when the structural forms influence socioeconomic reproduction in a positive systemic manner.

For instance, Fordism only led to upswing in the 1940s and 1950s when the dominant semi-automatic assembly line processes in motor vehicle and consumer durables industries (promoting productivity) developed a suitable accord between capital and labor and an active mode of demand for final consumer goods (effective demand). The 
technical requirements of innovation and production need to be dynamically balanced by distributive stability and markets. Further institutional or structural forms reinforced the wave upswing through the institutions of the financial system, world economy, population dynamics, and other relationships. However, in the 1960s and early 1970s, Fordism had reached the end of its dynamic life as contradictions began to manifest, through maturity emerging in the established sectors, production/distribution conflict between capital and labor, and the institutions of money, trade, and world economy coming into disarray. Since then, during the 1980s and 1990s, neoliberalism has reinforced the lack of effective demand and distributional inequality, thereby inhibiting productivity dynamics in a Kaldorian fashion of circular and cumulative downswing. Some "regulation scholars" believe that a long wave upswing has emerged into the 1990s and/or 2000s for the global economy or some nations, while others disagree and think that long wave downswing is still operational.

Fourth, David Gordon (1978, 1980, 1998)_along with colleagues Samuel Bowles, Richard Edwards, Michael Reich, and Thomas Weisskopf-developed a sophisticated analysis of institutional change in the social structures of accumulation explanation of waves. The social structure of accumulation (SSA) theory of long-term capitalist evolution posits the notion that the building of a new favorable set of institutions provides the certainty and stability necessary for sustained investment during long wave upswing. For instance, in the postwar era the "core institutions" associated with US hegemony, the capital-labor accord, Keynesian-welfare state, and a system of moderation of competition, propelled a suitable regime for rapid investment and growth during the 1950s, 1960s, and early 1970s. But the contradictions within the structure manifested themselves as the late 1960s evolved into the early 1970s, as the core institutions deteriorated through the emergence of full employment, challenges to US hegemony, rising regulations and forces against corporate power, and other factors that reduced the rate of profit and hence accumulation from the late 1960s onwards into the 1990s (see Kotz et al. 1994).

The capital-labor accord deteriorated as worker power challenged capital through wage and conditions improvements and productivity decreases. The Keynesian-welfare state upset investment and growth through greater regulations and taxes on capital and expansions of the social wage. US hegemony declined as the Vietnam War was lost, relative productivity increases favored Europe and eventually Asia, and global uncertainty emerged. And greater competition reduced profitability as monopoly profits declined through the age of globalization and neoliberalism. The major social structures underlying accumulation deteriorated so that, by the 1970s and 1980s, long wave downswing had set in, continuing through the 1990s and possibly 2000s, although some SSA scholars (again) believe that long wave upswing emerged into the 1990s.

This SSA approach teaches us that institutions, which individual capitalists by themselves are usually powerless to influence, provide the socioeconomic resources for stability and conflict resolution. The system requires certain "public goods" or "systems functions" to promote accord, agreement, organization, communication, and information to moderate conflict and instability that so-called "free markets" would otherwise largely be without. The economy is situated within an institutional and organizational environment that is critical to long-term decision-making and socioeconomic action. But the institutions also contain contradictory processes that limit their dynamic functioning 
through long historical time. Hence institutional solutions may be long lasting, but ultimately transitory. New relations and sociopolitical processes take time to rebuild and reshape, especially in a predominantly market-based system with its "disembedded economy" and greater systemic uncertainties. When the contradictions manifest strongly, economic and social performance can diminish, leading to a need for institutional renewal.

The current book is especially influenced by the regulation and SSA approaches. A number of scholars have recognized similarities as well as differences between the regulation and SSA approaches. For instance, Robert Went (2002) recognizes that these two traditions are both non-deterministic in the sense of linking together historical and institutional transformation, with a holistic method that can be potentially applied to many different situations. ${ }^{17}$ David Kotz (1994) recognizes that both approaches link capital accumulation with institutions through phases of capitalist development, periodically manifesting in a structural crisis of generally lower accumulation and profitability. The main difference is that the regulation approach is more structural in its emphasis on accumulation and technological dynamics rather than class struggle and institutions as the active forces. The regulation approach is said to be more materialistic, while the SSA theory places more emphasis on relationships, agreements, and conflicts between classes and institutions. Kotz concludes that the structural explanation is more appropriate for the very long run, while the relationships and institutions method is better at explaining the shorter time horizon. For the "intermediate term" that both approaches seek to explain, however, "one is too structural and the other is too voluntarist," and hence, if "greater interchange between the two schools moves each toward the position of the other that should be good for both of them" (Kotz 1994:96).

Indeed, the current work found it necessary to fuse the two approaches in order to make a coherent analysis of recent movements of the long wave. I have come to recognize the importance of the regulationist concept of the mode of regulation, which includes a regime of accumulation; the linkage between a production style (ensuring productivity), and a mode of consumption (ensuring adequate demand). But whereas the regulation school approach tends to give secondary importance to the institutional or structural forms of the state, money, global relations, and the family, my empirical analysis fails to uphold this hypothesis. Instead, I have found the regime of accumulation to be equally important as the "structural forms," or "institutional spheres” as I have called them (O’Hara 2000). Furthermore, my empirical analysis has demonstrated that international relations and family-community relations are crucial to an understanding of long waves, and hence that "politics" and "society" are more important than the regulation approach typically allows. ${ }^{18}$

Hence, rather than giving secondary importance to the institutional forms, they are more critical than the regulation approach generally gives credence. Indeed, the regime of accumulation is a critical set of institutional forms itself, since the technological and accumulation dynamics of capitalism become organized and institutionalized and are affected by the distributive and social relations of capitalism. Furthermore, the regime of accumulation and the so-called institutional forms are interdependent and critically interlinked both as process and also causally. Hence the analysis of this book scrutinizes the regime of accumulation, but with the recognition that institutions, habits, 
technologies, and organizational arrangements are embedded in both the regime of accumulation and the structural forms.

Apart from including work on the core institutions of the state, corporation, capitallabor relations, and the world economy, and the inclusion of the financial system (originated by Wolfson 1994), I have tried to advance the social structure of accumulation analysis by including in the analysis "family and community" relations (see O’Hara 1995, 2004). On the latter, recent research has demonstrated the critical importance of trust, association, and networks in the political and social forces underlying economic growth and development. This is ideally suited to the task because in including such relationships typical social structure of accumulation concerns of conflict, inequality, ethnicity, gender, and cooperation are linked to institutional aspects of skill formation, the quality of labor power, the influence of family and community on the wider economy, and the importance of social structure on economic performance. Indeed, as further research is undertaken in different epochs and areas, new hypotheses will forever emerge in the literature to advance the social structure of accumulation and regulation analyses of long-term motion. ${ }^{19}$

\section{Structure of the book}

The structure of this book is oriented around various potential SSAs or MORs. There are two clusters of potential SSAs/MORs examined here, illustrated in Figures 1.1 and 1.2, respectively.

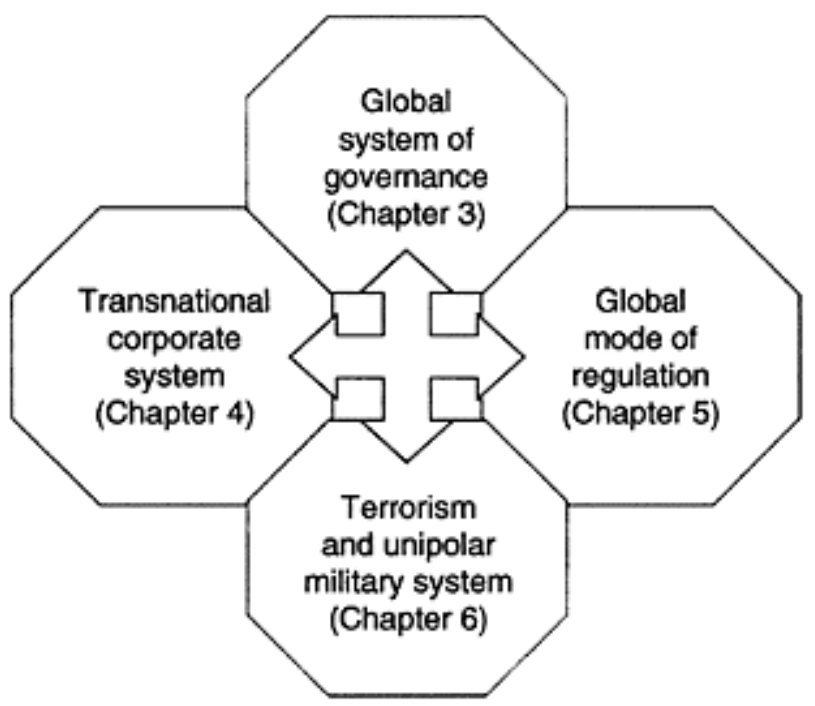

Figure 1.1 Global System of Power and Accumulation. 


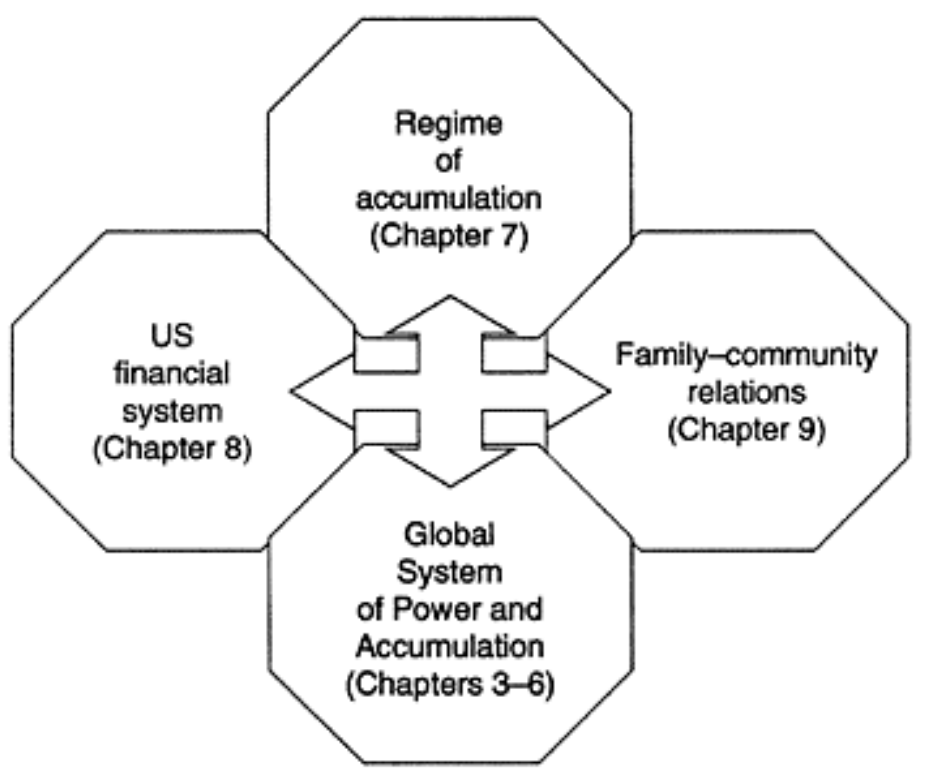

Figure 1.2 US System of Power and Accumulation.

The first cluster is called the Global System of Power and Accumulation, and includes the global governance structure (neoliberalism) (Chapter 3), the transnational corporate system (Chapter 4), the global MOR of production-money-trade (Chapter 5), and terrorism and the trend to a unipolar military system (Chapter 6). SSAs and MORs are power structures that impinge on accumulation dynamics. This is the first study to apply the SSA approach extensively to the global arena; the recent global trend makes this more feasible than in earlier decades. The global systems of governance, corporate relations, production-money-trade, and military-international relations are the most important contemporary socioeconomic and political institutional relationships operating at the global level, and they must thus be center stage in the analysis.

The Global System of Power and Accumulation is critical to an understanding of the dominant relationships underlying the power and accumulation dynamics of the global political economy. The central core of this system over the past few decades has been the relationships associated with neoliberalism, or more specifically the evolution from the Keynesian-welfare state to the deregulated governance system of neoliberalism. No doubt the system as it operates in its many global and regional dimensions has become a hybrid, but certainly the deregulation imperative is a critical part of its operational dynamics. Closely linked to neoliberalism is the transnational corporate system, where transnational firms, foreign direct investment (FDI), and the global power of capital have been working hand in glove with the forces of neoliberalism to enhance business performance. Out of this emerges the global MOR associated with attempts to improve productivity and market sales in the regime of accumulation, as well as neoliberal attempts to enhance the flow of finance and trade through international institutions. More 
recently neoliberalism has been merged in some areas with the neoconservative attempt to impose a unilateral mode of intervention against global terrorism and the axis of evil so as to enhance the system of global capital.

The second cluster relates to the US System of Power and Accumulation, including the regime of accumulation (Chapter 7) the structural forms (or potential SSAs) of finance (Chapter 8) and family-community (Chapter 9), and the interlocks with the Global System of Power and Accumulation (Chapters 3-6). To truly understand the Global System of Power and Accumulation, however, it is necessary to analyze certain regional and national forces as well. A comprehensive view of these forces is beyond the scope of this study. But three chapters are included of the dominant national economy that seeks global hegemonic dominance: the United States. An investigation of the trends associated with the US System of Power and Accumulation should provide some insights into the potential for long wave upswing into the future as engendered by more national trends and relationships. For this reason, we examine the US regime of accumulation associated with potential productivity and sustainable demand, as well as the US financial system and the system of family- community relationships. The US System of Power and Accumulation is also linked to the Global System of Power and Accumulation in critical ways since neoliberalism, transnational corporations, technology systems, and the war on terrorism and rogue states centrally impinges on US citizens as well. This needs to be taken into account when surveying the potential for long wave upswing in the United States.

Chapter 2, then, commences the analysis through a general interpretation of why the global political economy has failed at this stage in history to emerge into sustainable long-term growth and development. Here the cultural contradictions are scrutinized so as to comprehend the general systemic anomalies of global capitalism. A contradiction is an endogenous, systemic inextricable linkage of positive and negative elements, where the positive and negative elements variously emerge as the dominant patterns and processes through historical time, and where unless suitable changes emerge the negative elements will gradually become manifest and dominate the system. To comprehend these contradictions, therefore, we need to understand what the positive and negative processes are and how they affect the operations of the system. The positive elements of the contemporary system of global capitalism are that it is a revolutionary system, forever changing the technological and institutional fabric in search for profitability, greater markets, and accumulation.

Part and parcel of these dynamics are the negative elements, that it upsets established relationships between people through declining levels of trust, sociality, and cooperation: The rise in individualism and competition reduces profitability; the demise of public capital leads to a deterioration in external benefits associated with productivity and network linkages; an expansion of financial motives reduces the spirit of workmanship; an increase in unilaterialism and US cultural hegemony creates conflict with other social beliefs such as (radical) Islam; and the destruction of family and community relationships creates problems of lack of trust and social network formation. Overall this expands the level of socioeconomic uncertainty thus adversely affecting investment, consumption, and long-term planning of human association.

Chapters 3-6 detail the Global System of Power and Accumulation. Chapter 3 critically scrutinizes the dominant governance system of neoliberalism, which despite 
some degree of moderation of late is still the most powerful global ideology underpinning governance practices. It is shown that the neoliberal state that is emerging out of this process of transition is also undergoing a contradictory process. In redirecting spending from productive activities such as the transport network, communications, health, and education toward transfer payments the degree of crowding out has increased. In contributing to the rising power of capital versus labor it has contributed to inadequate effective demand. In concentrating on monetary policy and the expanding sharemarket, it has reduced the relative dominance of industrial versus pecuniary propensities, so that industry becomes a sideshow to finance. And in promoting market relationships such as trade and finance it has contributed to the decline in family and community, linked to declining trust and association. Overall, neoliberalism is inhibiting the progress of a new long wave of growth and development.

Chapter 4 analyzes the second element of the global system of power, the transnational corporate system. The positive elements of the transnational corporate system are expanding levels of foreign direct investment, cross border mergers and acquisitions (M\&As), and high-technology exports. These have been emphasized much in the literature. But the negative aspects are more powerful, including the collapse of foreign direct investment during the early years of the 2000s, the crowding out effect of foreign direct investment on domestic private investment in Latin America, the inability of transitional economies of Eastern Europe to reestablish previous levels of growth and development, and the barriers of capitalism to enhancing performance in most areas of Sub-Saharan Africa and the Middle East. Rates of profit, accumulation, productivity, and GDP growth have thus remained at recessed levels for the global corporate system.

Chapter 5 studies the third part of the global system of power, the viability of the global production-money-trade SSA or MOR. This involves studying the regime of accumulation (production-distribution), and the (proxy) structural forms of the International Monetary Fund (IMF) and the World Trade Organization (WTO). The system of production and distribution is insufficiently promoting profit, productivity, and demand. The WTO is in some degree of limbo due to conflicts within the organization and criticism from without. And while there are some recent changes in the IMF to promote financial stability, recent developments have (on balance) seen increasing instability and uncertainty that is inhibiting sustained renewal and reproduction. It is concluded that a global money-trade-production social structure of accumulation or mode of regulation has not emerged.

Chapter 6 looks at the fourth aspect of the global system of power, the unipolar war on terrorism and rogue states. The Cold War that emerged during the 1950s-1960s provided a reasonable balance of power so that neither the capitalist nor nominally "state-socialist" systems could control the world. This occurred while the United States provided the hegemonic leadership and control to promote growth and development for the advanced capitalist nations during this period. However, the demise of the Cold War and the Soviet Block during the 1980s and 1990s left a power vacuum that led to the emergence of fundamentalist religious groups advocating Jihad or holy war. Bin Laden and his associates in many ways are more of a threat to the Western world than the Soviets were, since they can move from nation to nation, utilize a global strategy of terror (to counter the terror they see as being initiated by the United States), and strike anywhere with no 
notice. This has inhibited the development of a durable and stable environment of international relations, and promoted increased uncertainty throughout the world.

Chapters 7-9 detail the US System of Power and Accumulation. Critical aspects of the US social economy are analyzed, on the assumption that the United States is the dominant nation and to some degree even domestic institutional trends are leading the world in a specific direction. Scrutinizing aspects of the US system, therefore, potentially provides some indication of the nature of global trends in the foreseeable future. Special reference, then, is given to three areas within the general MOR: the regime of accumulation, and the structural forms of the financial system and the family and community. The analysis of the regime of accumulation enables one to ascertain whether the conclusions made in Chapters 2-6 are reinforced by national trends in the United States (and in similar nations). National trends in the US financial system have also been seen to influence trends elsewhere in the world, and the same is true of the question of family and community formation. Hence, these three chapters are important in order to provide clues not only for the evolution of the United States but also for the global system.

Chapter 7, therefore, investigates the regime of accumulation-the first element of the US System of Power and Accumulation-which is found not to be satisfactorily developed. The regime of accumulation is faulty since the technical and social relations are not sufficiently promoting productivity while the distributive relations are insufficiently propelling demand. This is because certain contradictions are manifesting themselves profoundly. The first contradiction is that modern information and communications technology (ICT) is helping people to solve technical problems of production and communication but not enhancing sustainable productivity due to ICT being a pale imitation of previous technological advances. The second contradiction is that the institutions of distribution are, ironically, based on capital (including finance capital) being more powerful than labor, which creates major problems of effective demand and financial instability. Thus, lack of sustainable productivity and demand prevent the emergence of long wave upswing.

Chapter 8 investigates the second aspect of the US System of Power and Accumulation - the domestic financial system. Three areas are examined: financial stability, relations between industry and finance, and financial profit and productivity. All these areas have been found to be lacking. Financial instability has deepened as a result of deregulation, sharemarket value, and monetary policy dominance. The emergence of speculative bubbles inhibits the instinct of workmanship, leading to periodic crashes and deep recession. The resulting conflict between industry and finance has increased such that finance does not adequately promote industry. And long-term bank profit and productivity has been hindered by the short-termism of shareholder value and competition in the market. Overall, the national tendency has been for financial changes to increase uncertainty and instability, and this pattern is being followed in many other nations.

Then we turn in Chapter 9 to the last element of the US System of Power and Accumulation-institutions of the family and community. It was found, again, that the changes that enhance market relations have destroyed critical elements of trust, association, and stability. Nationally, the family is under threat from the expansion of commodification, increasing geographical mobility, and the rise of individualism. The 
political and social system is threatened by the decline in "connective" associations where people interact in friendly and generous ways, sharing perspectives and relationships. The political system is under threat through the national (and international) trend toward lack of political participation, not being actively involved in community decision-making and social indifference. And the culture is under increasing threat as class distinctions, ethnic divisions, and fragmentation become worse. Society is literally cracking under the pressure of neoliberal reforms, cultural changes, and technical modifications, and much of the rest of the world is changing in a similar direction.

Overall, a long wave upswing does not appear to be emerging or in place because the dominant institutions are insufficiently helping to embed society within economy. ${ }^{20}$ Many people are experiencing sudden shocks that reduce their ability to be involved in change. Market relations reduce the safety nets that people require during times of crisis and uncertainty. Economic growth has dampened while social and political development is also being inhibited. The new innovations are not comparable to previous clusters of technological change in their impact on productivity. Demand is inhibited as neoliberal governments provide a system of legality and basic distribution without actively propelling productive state goods and services that crowd in private investment. The system of international relations is stimulating terrorism and war, leading to more uncertainty and instability. Financial deregulation has expanded the interests of finance rather than industry, leading to greater speculative bubbles and recessions. And familycommunity relations are becoming more fragile and subject to strain and collapse due to declining trust and association.

In a circular and cumulative fashion, therefore, we are currently engaged in considerable institutional instability and fragmentation that is inhibiting global growth and development. Neither the Global nor the domestic US System of Power and Accumulation are well formulated to promote long-term growth and development. Chapter 10 outlines policies that should help to generate sustained growth and development in the global and many national or regional political economies. A post neoliberal system of governance is presented. Such a system needs to establish greater trust, community warranted knowledge, and participation in the community. This requires government spending on productive state activities such as education, health, infrastructure, and communications. It also requires some degree of financial control over practices of speculation and hoarding. Fundamentally it also necessitates developing a more extensive system of statistics to assess the degree of fragmentation and uncertainty, beyond established national accounts and proxies. It also requires bridging the gaps established between different classes, religions, and cultures throughout the world. A holistic governance framework needs to be developed, that links together technological, industrial, social, and environmental aspects. Systemic changes are necessary before the world as a whole can develop over the next few decades.

We now begin the story in Chapter 2 with the dominant contradictions of global capitalism. Here we link together most of the positive and negative elements of the system in synthetic overview. We examine the contradictions associated with individual versus system requirements, lack of growth and productivity, declining welfare and environmental sustainability, conflict between industry and finance, the effects of individualism on trust and community, and the limits of unilateralism and US dominance 
in a complex and uneven system of cultures and conflicts. Subsequent chapters examine the respective contradictions in more institutional detail.

\section{Notes}

1 This reference to "take-off" is a general use of the term to mean the phase when certain nations or areas advanced suddenly into industrial capitalism, following the usage of Eric Hobsbawm (1975). This does not necessarily imply that I accept W.W.Rostow's (1960) use of the term, or his associated theory of stages of growth. See also Paul A. Baran and E.J.Hobsbawm (1961).

2 Here I am referring to the resurgence of political economy during the 1960s, 1970s, 1980s, and 1990s in the form of radical, institutional, feminist, post Keynesian, and social-political economy. Details of this movement and its various schools are available from O'Hara (2000, 2001). There are other versions of political economy, most especially that of the public choice and constitutional political economy perspective; but this is not utilized in this study, first, because they don't seem to have examined long waves and, second, because I don't have the required knowledge to attempt such a program.

3 For an analysis of the principles of political economy, and how they can be related in practice, see O’Hara (2000, 2001, 2003, forthcoming). These principles have been developed by scholars publishing in journals such as the Journal of Economic Issues, Cambridge Journal of Economics, Review of Radical Political Economics, Journal of Post Keynesian Economics, Feminist Economics, Review of Social Economy, Review of International Political Economy, Capital and Class, New Political Economy, Review of Political Economy, International Review of Applied Economics, Rethinking Marxism, Journal of Institutional Economics, and so on.

4 The reader may think there is a conflict between my assertions that institutional change usually takes a long time to emerge and the notion that long wave upswings and downswings can quickly manifest themselves. There is no conflict here, though, because (a) sometimes institutional changes do happen quickly, and (b) often the changes are slow but the manifestation of those changes in terms of socioeconomic performance can be apparently rapid. Also, change is relatively indeterminate as well, since the relationship between aspects of the dynamic structures is not completely tight, and therefore changes can be uneven. Some aspects of the institutional structure therefore, can emerge quickly even if other aspects are of a slower nature. One needs to also link the critical aspects of individual, habitual and institutional changes (agency and structure) as a causal series of processes. This is not done in detail here, since the emphasis is less theoretical and more institutional; but Geoffrey M.Hodgson (2004) does discuss this in some detail.

5 J.J.van Duijn (1983) demonstrated that long waves are global processes of growth and accumulation, which do not necessarily correspond to all national economies. The long wave pattern is thus said to appear when the main statistics of nations are aggregated so that a global perspective emerges. As he said: "this statistical pattern confirms that world industrial production follows a long wave pattern: a pattern which cannot convincingly be found in the industrial production series of our four core countries, with the exception of France" (van Duijn 1983:156). This, of course, does not mean that long waves only exist for the global economy, but that it also exists for some (and not all) national economies.

6 Many scholars do not much like the term "holistic" because they sense that it means the dominance of structure over agency. But this is not the use of the term here. Rather, holistic refers to (a) the need for a multifactor (or multi-institutional) analysis of capitalism, (b) where the critical relationships are often considerably interdependent, and where (c) one needs to examine the linkages between individuals, habits, and institutions. Generally it also refers to a cultural analysis of socio-political economic systems, being the dominant ways of 
life of the people. See Chapter 2 for some more detail on these cultural aspects and the pages of O’Hara (2001).

7 Richard Edwards, for instance, has studied the labor process for the United States and concludes that simple forms of control were dominant in the labor process from at least as early as the first decade of the nineteenth century until the 1880s or early 1880s. As he said, for this simple form of control, there is a single entrepreneur, usually flanked by a small coterie of foremen and managers, [who] ruled the firm. These bosses exercised power personally, intervening in the labor process often to exhort workers, bully and threaten them, reward good performance, hire and fire on the spot, favour loyal workers, and generally act as despots, benevolent or otherwise. (Edwards 1979:18-19) By the late 1880s technical control through the machinery and assembly line became common in the dominant sectors, while by the 1940s and 1950s bureaucratic control was common through internal corporate norms, laws and relationships (along with segmented labor markets). However, as Richards emphasises, in the periphery (continental, regional, corporate) other (lower) forms of control can be common apart from the dominant ones of the era (see also Gordon et al. 1982).

8 As Giovanni Arrighi said of the emergence of British hegemony:

The United Kingdom first became hegemonic by leading a vast alliance of primarily dynastic forces in the struggle against these infringements on their absolute rights of government and for the restoration of the Westphalia system. This restoration was successfully accomplished with the settlement of Vienna of 1815 and the subsequent Congress of Aix-la-Chapelle of 1818.... [T]he United Kingdom went on to govern the inter-state system and, in doing so, it undertook a major reorganization of that system aimed at accommodating the new realities of power released by the continuing revolutionary upheaval. The system that came into being is what John Gallagher and Ronald Robinson...called free-trade imperialism.

9 Of course, in the United States, the civil war that occurred in the 1860s has made an analysis of upswing more complex. But it is certainly true that upswings are not simply economic growth but also development, and in this respect liberal capitalism was developed quite significantly through the process of outlawing the slave system in the South, even though it wasn't until the 1950s and 1960s that the civil rights movement had their greatest successes.

10 But note that there is much debate about this in the literature (see, for instance, Tylecote on this; 1992:216-218). The nature of the 1970s-1990s "great contraction" is controversial in economic history debates. Saul (1969) examines the views and evidence and concludes two things. First, in relation to the period 1873-1896, Saul (1969:55) concludes that 'this much is clear: the sooner the 'Great Depression' [notion] is banished from the literature, the better.” Nevertheless, he also says that "The events of the 1870s and 1880s, whatever the factors underlying them, caused a serious decline in business confidence. The unusual economic environment may well have lowered expectations and in this way reduced the level of industrial investment. It is an intangible influence, but contemporary accounts suggest it was not an insignificant one" (Saul 1969:53-54). Saul goes on to say that it is a "fact that at some time during the last quarter of the nineteenth century Britain and several countries overseas went through unusual and worrying economic experiences which sometimes they characterised at the time as 'a great depression'” (1969:54). If this account is a fair interpretation of the period, then it is not far fetched to call the period 1873-1896 a period of "relative economic deterioration" a la our interpretation (as also Freeman and Louca 2002 agree). 
11 There are different interpretations of the "Taylor" production system, from those who distance Frederick Winslow Taylor (1856-1915) from "Taylorism" (Nyland 2001) to those who speak more of "Taylorism" in general (Aglietta 1976). For instance, on the latter Aglietta defines Taylorism as

The sum total of those relations of production internal to the labor process that tend to accelerate the completion of the mechanical cycle of movements on the job and to fill the gaps in the working day. These relations are expressed in general principles of work organization that reduce the workers' degree of autonomy and place them under a permanent surveillance and control in the fulfilment of their output norm.

12 This greater significance for Schumpeter of late is perhaps best reflected in the assessment of Allen Oakley (1990), who views "these several critical observations [as] intending to have a positive thrust” (in Oakley’s analysis). As he says:

From the limitations of Schumpeter's analyses, we can identify some future directions for improving our understanding of motion. To a large extent these remain unexplored to their full potential.... Perhaps as much remains to be done with the[se]...insights that Schumpeter left us.

(1990:238-239, 243)

He mentions aspects that remain to be developed further as including the notion that capitalism is inherently unstable, the circular flow analysis, the historical centre of gravity method, the sectoral and class-agent mesoeconomics, the role of production and innovation, human agency, monetary processes, uncertainty and insecurity, and monopoly power and market structure.

13 There has been a long and complex debate and empirical analysis of the significance of the organic composition of capital and its role in affecting the rate of profit. Some of the key works - of a heterogeneous nature connected with the "surplus approach"-include Joseph Gillman (1957), Michael Lebowitz (1976), James (O’Connor), Thomas Weisskopf (1979), Edward Wolff (1987), John Davis (1992), Anwar Shaikh and E.Ahmet Tonak (1994), Anders Danielson (1994), and Stephen Cullenberg (1994). The balance of evidence is against the organic composition as one of the critical factors affecting the rate of profit.

14 There are a variety of other approaches to long waves that have permeated the literature. For instance, Michael Marshall (1987) places emphasis on the regional dimension of long waves, paying particular attention to the experience of Britain. Joshua Goldstein (1988) places emphasis on the role of war and hegemony in the "long cycle" dynamics. Brian Berry (1991) links the economics and politics of long waves, showing the role of politics in the whole process, including elections, world leadership, and mass psychology. And Manfred Neumann (1997) developed what appears to be a neoclassical analysis of long waves vis-àvis time preference, capital formation, technological change, development, and business cycles. 
15 One important reason for these differences, for instance, is that the economic, political, and military power of nations change due to the complexities of socio-historical motion and the evolutionary tendencies in process. Western power since the 1960s has declined in relative terms compared with many Asian nations, which have in most cases experienced a dramatic increase in standard of living defined in traditional terms as GDP per capital, but also including the Human Development Index. Many see these dynamics as being related to changing hegemonic processes, such as the rise and fall of Dutch, British, and the US hegemony since at least the dawn of capitalism (see Wallerstein 1983; Arrighi 1994). There are some differences among these historical scholars of long-term motion, for instance, between the work of Andre Gunder Frank and Immanual Wallerstein, since Frank has hypothesized the existence of a 5,000 year world system (Frank and Gills 2000), while Wallerstein tends to examine this in terms of the capitalist World-System in existence in its earliest phases since about the 1500s (Wallerstein and Palat 1999).

16 I am suggesting here that there appear to be many similarities between the work of Perez and Tylecote and the regulation school. It should be noted, though, that there are a number of trends or schools within the regulation approach, and that they do have somewhat different perspectives on long-term growth and development under capitalism. The model mainly discussed in this chapter is the one emphasizing the MOR, which can be decomposed into an ROA and the structural forms (of institutions). So the model used here is a rather traditional regulation approach. See the five volumes of Bob Jessop (2001) for a detailed analysis of the regulation schools and many works undertaken over the years.

17 Robert Went also included another theory that is fairly non-deterministic: that of Ernest Mandel, who developed an analysis of the rate of profit based on endogenous (for the downswing) and exogenous (for the upswing) factors. The current work does not utilize Mandel's theory because of the relatively deterministic emphasis on the organic composition of capital. Also, the current work is an analysis of institutions, and Mandel does not put institutions at the center of his theory in an explicit sense, even though it obviously does include them. Nevertheless, Mandel's work was critical for the renaissance of interest in long waves since the 1960s, not to mention his Marxist analysis in general which to some degree lies outside the scope of this work. Like the current work, Went is unimpressed by single factor theories of long waves, such as those that concentrate almost entirely on technological change (see Went 2001: ch. 5).

18 On the topic of empirical analysis of long waves, Jonathan P.Goldstein (1999) has done some quite rigorous and interesting econometric analyses of long waves for a host of advanced capitalist nations following, he says, the footsteps of David M.Gordon. As he concludes:

I conclude that long waves clearly exist, are endogenous, and are weak-form synchronous, implying that traditional transmission mechanisms (trade and capital flows) rather than structurally similar cycles underlie the universality of such cycles.... For the last two waves (post-1983), these cycles show a high degree of conformity with the orthodox dating of long waves found in the literature.

19 This work on family and community relations does utilize recent research on trust, networks, association, and ethnicity. Included here are concerns with concepts such as "social capital," "ethnic capital," as well as "human capital.” Many political economists I have related to over the years do not much like these concepts because they seem to allude to neoclassical formulations. However, I do not believe this is necessarily the case, but more importantly it is critical to include the processes involved in these notions because they are important. In 
other words, trust, association, social dislocation, skills, and the like are critical to aspects of this work whether or not one links them to the prevailing concepts or not.

20 There are many challenges to scholars who are studying long waves. For instance, critiques emerge from time to time (see, for instance, Solomos Solomou 1998). These critiques try to establish that there are problems in verifying long wave periodicities; or that the long wave theory does not have an endogenous explanation of the upswing; or that statistical techniques are inadequate. Many criticisms inadequately emphasize that modern wave students are not proposing a deterministic approach, and are more interested in long historical trends and uneven developments than strict periodicities, amplitudes, and regularities. To surmount these challenges scholars, will need to emphasize the complexity of change, situate national trends in a global context, improve their statistical analysis of complex variables (see Jan Reijnders 1990), and show how the durable structures of the economy evolve over time in more detail. Long wave analysis in the future, it is hoped, will become less a theory of regularized economic behavior and more an evolutionary approach to long-term transformations in the world, regional, and national economies. Each of the political economy approaches to long waves is in the adolescent phase of maturity.

\section{References}

Aglietta, Michel. (1976) A Theory of Capitalist Regulation: The US Experience, London: New Left Books, 1979.

Aglietta, Michel. (1998) "Capitalism at the Turn of the Century: Regulation Theory and the Challenge of Social Change,” New Left Review, Number 232, pp. 41-90.

Arrighi, Giovanni. (1994) The Long Twentieth Century: Money, Power and the Origins of Our Time, London and New York: Verso.

Baran, Paul A. and Eric J.Hobsbawm. (1961) “The Stages of Economic Growth,” Kyklos, Volume 14, pp. 234-242. Reprinted in Paul A.Baran (1969) as "A Non-Communist Manifesto," The Longer View: Essays Towards a Critique of Political Economy. New York: Monthly Review Press, pp. 52-67. Edited with an Introduction by John O’Neill. Preface by Paul M.Sweezy.

Beaud, Michel. (1984) A History of Capitalism 1500-1980, London: Macmillan. Translated by Tom Dickman and Anny Lefebvre.

Berry, Brian J.L. (1991) Long-Wave Rhythms in Economic Development and Political Behaviour, Baltimore, MD and London: John Hopkins University Press.

Bowles, Samuel, David M.Gordon, and Thomas E.Weisskopf. (1990) After the Waste Land, Armonk, NY and London: M.E.Sharpe.

Brenner, Robert. (1998) "Uneven Development and the Long Downturn: The Advanced Capitalist Economies from Boom to Stagnation, 1950-1998,” New Left Review, Number 229, May-June, pp. 1-228.

Clarke, Hyde. (1847) "Physical Economy -A Preliminary Inquiry into the Physical Laws Governing the Periods of Famine and Panics,” Railway Register, pp. 2-15.

Cullenberg, Stephen. (1994) The Falling Rate of Profit: Recasting the Marxian Debate, London and Boulder, CO: Pluto Press.

Danielson, Anders. (1994) The Economic Surplus: Theory, Measurement, Applications, London and Westport, CT: Praeger.

Davis, John B. (ed.) (1992) The Economic Surplus in Advanced Economies, Aldershot, UK and Brookfield, WI: Edward Elgar.

Dowling, Bartholomew. (2003) Is the Long Wave Getting Shorter? Working Paper 08/2003 Judge Institute of Management Studies, Cambridge University.

Duijn, van J.J. (1983) The Long Wave in Economic Life, London: Allen \& Unwin. 
Edwards, Richard. (1979) Contested Terrain: The Transformation of the Workplace in the Twentieth Century, New York: Basic Books.

Frank, Andre Gunder and Barry K.Gills. (2000) "The Five Thousand Year World System in Theory and Praxis,” in R.A.Denemark, J.Friedman, B.K.Gills, and G.Modelski (eds), World System History: The Social Science of Long-Term Change. London and New York: Routledge, pp. 323.

Freeman, Chris and Francisco Louca. (2002) As Time Goes By: From the Industrial Revolution to the Information Revolution, Oxford: Oxford University Press.

Freeman, Christopher, John Clark, and Loc Soete. (1982) Unemployment and Technical Innovation: A Study of Long Waves and Economic Development, London: Frances Pinter.

Garvy, George. (1943) “Kondratieff's Theory of Long Cycles,” Review of Economics and Statistics, Volume 25, Number 4, November, pp. 203-220.

Gelderen, van J. (J.Fedder). (1913) "Springvloed-Beschouwingen over industrieele ontwikkeling en projsbeweging,” Die Nieuw Tijd, Volume 18, Numbers 4, 5, and 6, pp. 254-277, 370-380, 446-464.

Gillman, Joseph M. (1957) The Falling Rate of Profit: Marx's Law and its Significance to Twentieth-Century Capitalism, London: Dennis Dobson Co.

Goldstein, Jonathan P. (1999) "The Existence, Endogeneity, and Synchronization of Long Waves: Structural Time Series Model Estimates,” Review of Radical Political Economics, Volume 31, Number 4, pp. 61-101.

Goldstein, Joshua. (1988) Long Cycles: Prosperity and War in the Modern Age, New Haven, CT and London: Yale University Press.

Gordon, David M. (1978) “Up and Down the Roller Coaster” in Crisis Reader Editorial Collective, U.S. Capitalism in Crisis, New York: Union for Radical Political Economics, pp. 22-35.

Gordon, David M. (1980) "Stages of Accumulation and Long Economic Cycles,” in T.Hopkins and I.Wallerstein (eds), Processes of the World-System, London: Sage Publishers, pp. 9-45.

Gordon, David M. (1998) Economics and Social Justice: Essays on Power, Labor and Institutional Change, edited by S.Bowles and T.Weisskopf, Cheltenham, UK and Northampton, MA: Edward Elgar.

Gordon, David M., Richard Edwards, and Michael Reich. (1982) Segmented Work, Divided Workers: the Historical Transformation of Labor in the United States, London and New York: Cambridge University Press.

Helphand, Alexander ("Parvus”). (1901) “Die Sturm and Drangperiode des Kapitals,” in Die Handelskrisen und die Gewerkschaften, Berlin: Olle \& Wolter, 1972.

Hobsbawm, Eric. (1962) The Age of Revolution: 1788-1848, London: Abacus, 1977.

Hobsbawm, Eric. (1975) The Age of Capital: 1948-1875, London: Abacus, 1997.

Hobsbawm, Eric. (1987) The Age of Empire: 1875-1914, London: Phoenix Press, 2000.

Hodgson, Geoffrey M. (2004) The Evolution of Institutional Economics: Agency, Structure and Darwinism in American Institutionalism, London and New York: Routledge.

Hossein-Zadeh, Ismael, and Anthony Gabb. (2000) "Making Sense of the Current Expansion of the U.S. Economy: A Long Wave Approach and a Critique," Review of Radical Political Economics, Volume 32, Number 3, pp. 388-397.

Jessop, Bob. (2001) Regulation Theory and the Crises of Capitalism, 5 vols, Chaltenham, UK and Northampton, MA: Edward Elgar.

Kleinknecht, Alfred. (1987) Innovation Patterns in Crisis and Prosperity: Schumpeter's Long Cycle Reconsidered, London: Macmillan.

Kondratieff, Nikolai Dimitrievich, and D.I.Oparin. (1928) Bol'shie tsikly kon'iunktury, Moscow: Krasnaia Presnia.

Kotz, David M. (1994) “The Regulation Theory and the Social Structure of Accumulation Approach,” in David M.Kotz, Terrence McDonough, and Michael Reich (eds), Social Structures of Accumulation: The Political Economy of Growth and Crisis, Cambridge, UK and New York: Cambridge University Press, pp. 85-98. 
Kotz, David M., Terrence McDonough, and Michael Reich, (eds) (1994) Social Structures of Accumulation: The Political Economy of Growth and Crisis, Cambridge, UK and New York: Cambridge University Press.

Kuznets, Simon. (1940) “Schumpeter’s Business Cycles,” American Economic Review, Volume 30, June, pp. 157-169.

Lange, Oskar. (1940) "Review of Business Cycles by Joseph A.Schumpeter," Review of Economic Statistics, Volume 22, pp. 190-193.

Lebowitz, Michael A. (1976) “Marx’s Falling Rate of Profit: A Dialectical View,” Canadian Journal of Economics, Volume 9, pp. 232-254.

Lenoir, Marcel. (1913) Etudes sur la formation et la mouvement des prix, Paris: Giard.

Lippit, Victor. (1997) "The Reconstruction of a Social Structure of Accumulation in the United States,” Review of Radical Political Economics, Volume 29, Number 3, pp. 11-21.

Maddison, Angus. (2000) The World Economy: A Millennial Perspective, Paris: Organisation for Economic Cooperation and Development (Development Centre Studies).

Mager, Nathan H. (1987) The Kondratieff Waves, New York: Praeger Publishers.

Mandel, Ernest. (1964) “The Economics of Neo-Capitalism,” Socialist Register, London: Merlin Press, pp. 56-67.

Mandel, Ernest. (1972) Late Capitalism, London: New Left Books, 1975.

Mandel, Ernest. (1995) Long Waves of Capitalist Development: A Marxist Interpretation, Second Edition, London and New York: Verso.

Marshall, Michael. (1987) Long Waves of Regional Development, New York: St. Martins Press.

Mensch, Gerhard. (1979) Stalemate in Technology: Innovations Overcome the Depression, Berlin: International Institute of Management Science Center.

Minsky, Hyman P. (1982) Can “It” Happen Again? Essays on Instability and Finance, Armonk, NY: M.E. Sharpe.

Moseley, Fred. (1999) "The United States at the Turn of the Century: Entering a New Era of Prosperity?” Capital and Class, Volume 67, pp. 25-45.

Neumann, Manfred. (1997) The Rise and Fall of the Wealth of Nations: Long Waves in Economics and International Politics, Cheltenham, UK and Lyme, CT: Edward Elgar.

Nyland, Chris. (2001) “Taylorism,” in Phillip Anthony O’Hara (ed.), Encyclopedia of Political Economy, London and New York: Routledge, pp. 1145-1147, Paper edition.

Oakley, Allen. (1990) Schumpeter's Theory of Capitalist Motion: A Critical Exposition and Reassessment, Aldershot, UK and Brookfield, WI: Edward Elgar.

O’Hara, Phillip Anthony. (1995) "Household Labor, the Family, and Macroeconomic Instability in the United States: 1940s-1990s,” Review of Social Economy, Volume 53, Number 1, pp. 89120.

O’Hara, Phillip Anthony. (2000) Marx, Veblen and Contemporary Institutional Political Economy: Principles and Unstable Dynamics of Capitalism, Cheltenham, UK and Northampton, MA: Edward Elgar, pp. 266-291.

O’Hara, Phillip Anthony, (ed.) (2001) Encyclopedia of Political Economy, 2 vols, London and New York: Routledge, Paper edition.

O’Hara, Phillip Anthony. (2003) Principles of Political Economy: Integrating Themes from the Schools of Heterodoxy. Working Paper, Global Political Economy Research Unit. Economics Department, Curtin University, http://pohara.homestead.com/files/\%20principles.doc

O’Hara, Phillip Anthony. (2004) "A New Family-Community Social Structures of Accumulation for Long Wave Upswing in the United States," Forum for Social Economy, Volume 34, Number 2, December, pp. 51-80.

O’Hara, Phillip Anthony, (forthcoming) Principles of Political Economy for a Global Age, Manuscript in progress.

Perez, Carlota. (1985) "Microelectronics, Long Waves and World Structural Change: New Perspectives for Developing Countries,” World Development, Volume 13, Number 3, pp. 441463. 
Polanyi, Karl. (1944) The Great Transformation, Boston, MA: Beacon Press, 1957.

Poletayev, Andrey V. (1992) "Long Waves in Profit Rates in Four Countries," in Alfred Kleinknecht, Ernest Mandel, and Immanuel Wallerstein (eds), New Findings in Long-Wave Research, London and New York: Macmillan and St. Martins Press, pp. 151-167.

Reijnders, Jan. (1990) Long Waves in Economic Development, Aldershot, UK and Brookfield, WI: Edward Elgar.

Rostow, Walt Whitman. (1960) The Stages of Economic Growth: A Non-Communist Manifesto, Cambridge: Cambridge University Press.

Rostow, Walt Whitman. (1978) The World Economy: History and Prospect, London and Basingstoke: Macmillan.

Rostow, Walt Whitman. (1980) Why the Poor get Richer and the Rich Slow Down: Essays in the Marshallian Long Period, London and Basingstoke: Macmillan.

Saul, S.B. (1969) The Myth of the Great Depression: 1873-1896, London: Macmillan.

Schumpeter, Joseph. (1911) The Theory of Economic Development: An Inquiry into Profits, Capital, Credit, Interest, and the Business Cycle, London and Oxford: Oxford University Press, 1969. Translated by Redvers Opie.

Schumpeter, Joseph. (1939) Business Cycles: A Theoretical, Historical, and Statistical Analysis of the Capitalist Process, 2 vols, Philadelphia, PA: Porcupine Press, 1982.

Schumpeter, Joseph. (1950) Capitalism, Socialism and Democracy, Third Edition, New York and London: Harper \& Row, 1975.

Shaikh, Anwar M. and E.Ahmet Tonak. (1994) Measuring the Wealth of Nations: The Political Economy of the National Accounts, Cambridge: Cambridge University Press.

Silver, Beverly. (1992) “Class Struggle and Kondratieff Waves,” in Alfred Kleinknecht, Ernest Mandel, and Immanuel Wallerstein (eds), New Findings in Long-Wave Research, London and New York: Macmillan and St. Martins Press, pp. 279-295.

Solomou, Solomos. (1998) Economic Cycles: Long Cycles and Business Cycles since 1870, Manchester, NH and New York: Manchester University Press.

Sweezy, Paul M. (1943) “Schumpeter's Theory of Innovation,” Review of Economic Statistics. Reprinted in Paul M.Sweezy (1953), The Present as History: Essays and Review on Capitalism and Socialism. New York and London: Monthly Review Press, pp. 274-282.

Tugan-Baranowski, Mikhail. (1894) Promyshlennye krizisy v sovremennoi Anglii, Petersburg: St. Petersburg.

Tylecote, Andrew. (1992) Long Waves in the World Economy: The Current Crisis in Historical Perspective, London and New York: Routledge.

Veblen, Thorstein. (1904) The Theory of Business Enterprise, New York: Augustus M.Kelley, 1975.

Veblen, Thorstein. (1923) Absentee Ownership and Business Enterprise in Recent Times, New York: Augustus M.Kelley, 1964.

Wallerstein, Immanuel. (1974) The Modern World-System I: Capitalist Agriculture and the Origins of the European World-Economy in the Sixteenth Century, New York and London: Academic Press.

Wallerstein, Immanuel. (1980) The Modern World-System II: Mercantilism and the Consolidation of the European World-Economy, 1600-1750, New York and London: Academic Press.

Wallerstein, Immanuel. (1983) "Three Instances of Hegemony in the Capitalist World-System,” International Journal of Comparative Sociology, Volume 7, Number 3, pp. 77-93.

Wallerstein, Immanuel. (1989) The Modern World-System III: The Second Era of Great Expansion of the Capitalist World-Economy, 1730-1840s, New York and London: Academic Press.

Wallerstein, Immanuel and Ravi Arvind Palat. (1999) "Of What World-System was Pre-1500 India a Part?,” in S.Chaudhuri and M.Morineau (eds), Merchants, Companies, and Trade: Europe and Asia in the Early Modern Era, Cambridge: Cambridge University Press, pp. 21-41.

Weisskopf, Thomas. (1979) "Marxian Crisis Theory and the Rate of Profit in the Postwar US Economy,” Cambridge Journal of Economics, Volume 3, Number 4, pp. 341-378. 
Went, Robert. (2001) Essays on Globalization: A Journey to a Possibly New State of Capitalism. Doctoral Thesis. University of Amsterdam: Faculty of Economics and Econometrics.

Went, Robert. (2002) Enigma of Globalization: A Journey to a New State of Capitalism, London and New York: Routledge.

Wolff, Edward N. (1987) Growth, Accumulation, and Unproductive Activity: An Analysis of the U.S. Economy, Cambridge: Cambridge University Press.

Wolff, de Sam. (1929) Het Economisch Getij, Amsterdam: J. Emmering.

Wolfson, Martin H. (1994) "The Financial System and the Social Structure of Accumulation" in D.M.Kotz, T.McDonough, and M.Reich (eds), Social Structures of Accumulation: The Poltical Economy of Growth and Crisis, Cambridge: Cambridge University Press.

World Bank. (2004) World Development Indicators Online, Washington, DC: World Bank. http://publications.worldbank.org/subscriptions/WDI/ (accessed August 6, 2004).

Yaghmaian, Behzad. (1998) "Globalization and the State: The Poltical Economy of Global Accumulation and its Emerging Mode of Regulation,” Science and Society, Volume 62, Number 2, pp. 241-265.

\section{Further reading}

Barr, Kenneth. (1979) “Long Waves: A Selected Annotated Bibliography” Review, Volume 2, Number 4, Spring, pp. 675-718. (This is a special issue of the Review on long waves.)

Freeman, Chistopher. (ed.) (1984) Long Waves in the World Economy, London: Frances Pinter. Hobsbawm, Eric. (1994) The Age of Extremes: 1914-1991, London: Abacus, 1995.

Kleinknecht, Alfred, Ernest Mandel, and Immanuel Wallerstein. (1992) New Findings in LongWave Research, London: Macmillan.

O’Connor, James. (1984) Accumulation Crisis, New York: Basil Blackwell.

O’Hara, Phillip Anthony. (1994) “An Institutionalist Review of Long Wave Theories:

Schumpeterian Innovation, Modes of Regulation, and Social Structures of Accumulation,” Journal of Economic Issues, Volume 28, Number 2, June, pp. 489-500. Reprinted in Francisco Louca and Jan Reijnders (eds), The Foundation of Long Wave Theory, Volume 2, Cheltenham, UK and Northampton, MA: Edward Elgar, pp. 354-365.

O’Hara, Phillip Antony. (2001) “Long Waves of Growth and Development,” in P.A.O’Hara (ed.), Encyclopedia of Political Economy, London and New York: Routledge, pp. 673-677, Paper edition. 


\section{2 \\ Cultural contradictions of global capitalism}

\section{Introduction}

In The Cultural Contradictions of Capitalism, Daniel Bell (1976) found that the decline of the bourgeois value system was brought about largely by the bourgeois economic system itself. In his opinion, the traditional values of American capitalism associated with the puritan temper and the protestant ethic were, from the 1960s onward, in conflict with the rising postmodern temper of the avante-garde and the "different." He believed that the economic system promoted avante-garde cultural values into the mainstream of cultural industries, and that this was in conflict with the spirit of work, trust, and stability. The capitalist economic system, therefore, necessarily propelled a cultural fabric that was against capitalism, and this was said to lead to many problems of reproducibility of the system. Advances in hedonism, "being all that one can," a consumption ethic, sexual liberty, and status emulation were in contradiction with the old values of frugality, industry, justice, modesty, and humility; and this would lead to many problems for capitalism. As a consequence, capitalism is said to have no coherent moral or philosophical doctrine to spur the system into motion as a positive motivational and inspirational force.

The ideas for this book were developed before the contradictions started to impact materially on the system, an early version of the idea emerging in 1969-1970. Since he wrote, many others have proffered an account of the dominant contradictions of capitalism (e.g. Stanfield 1995), but he was a major one paying attention to the cultural contradictions in the late twentieth century. However, his threefold dichotomy between social structure (economy), polity, and culture hardly helps comprehending the generalized cultural contradictions of the system, since for him culture is defined primarily as the industries associated with art, theater, film, advertising, and so on. A far better view of culture is that developed by institutionalists, for instance as follows:

[C]ulture [is] the whole of a people's patterns of regular and recurring behaviour... The idea [is] that human behaviour, belief, thought and artefact [are] all cultural patterns[.]...[E]mphasis [is] placed on the interrelatedness of component parts of culture, and upon cultural change as a consequence of that interrelatedness.... For all institutionalists who have followed the precepts of Veblen, Commons and Mitchell, culture has remained a central focus For institutional economists, with the concept of culture as their foundation,...studies of economic processes must, therefore, be holistic in approach. Change in economic institutions is always part of more general socio-economic change, always involves cumulative causation and is always path-dependent. 
(Anne Mayhew 1994:115-117; emphases added)

The cultural contradictions of global capitalism, therefore, must be holistically engrained in the system. They are complex, following the general lines of cultural evolution of the times, forever changing yet always emanating from the complex interactions that are the hallmark of global capitalism. They must be able to penetrate the dominant institutions, interact with other aspects of culture, and manifest to varying degrees through historical time. It is in this vein that we investigate the contemporary cultural contradictions of global capitalism. This chapter scrutinizes the dominant contradictions of the global political economy while the chapters that follow elucidate specific contradictions that permeate certain institutional spheres within the World-System.

\section{The dominant contradictions}

So what are the dominant cultural contradictions of the Global System of Power and Accumulation? First we need to comprehend the notion of contradiction. A contradiction is something endogenous to a complex system that is both central to its positive operational dynamics as well as being a necessary negative outcome of its modus operandi. Central to the notion of contradiction is that there are positive and negative aspects that simultaneously emerge from the dynamics of change and evolution. In general, the positives cannot exist without the negatives since they are part and parcel of the same processes (O’Hara 2001). The nature of the outcomes within these processes change through time, depending upon how the institutions, habits, and instincts operate and interact. During some periods, the outcomes can be generally progressive, while at other times they can be regressive, depending upon the balance of outcomes. The balance of forces change, and this illustrates that the notion of contradiction seeks to be a realistic, even pragmatic, and a policy-relevant tool of conceptual analysis of the concrete workings of the system.

The dominant contemporary contradictions of global capitalism are obvious enough, and emanate from visions linking the works of Karl Marx, Thorstein Veblen, Joseph Schumpeter, John Maynard Keynes, and Karl Polanyi. The major contradictions are illustrated in Figure 2.1, where the general contradiction links to simultaneous transformation and fragmentation, and the major specific contradictions link to systemindividual anomalies, industry-finance conflict, unstable and uneven performance, and unilateralism conflicting with global accord. The general cultural contradiction of capitalism, then, relates to the 


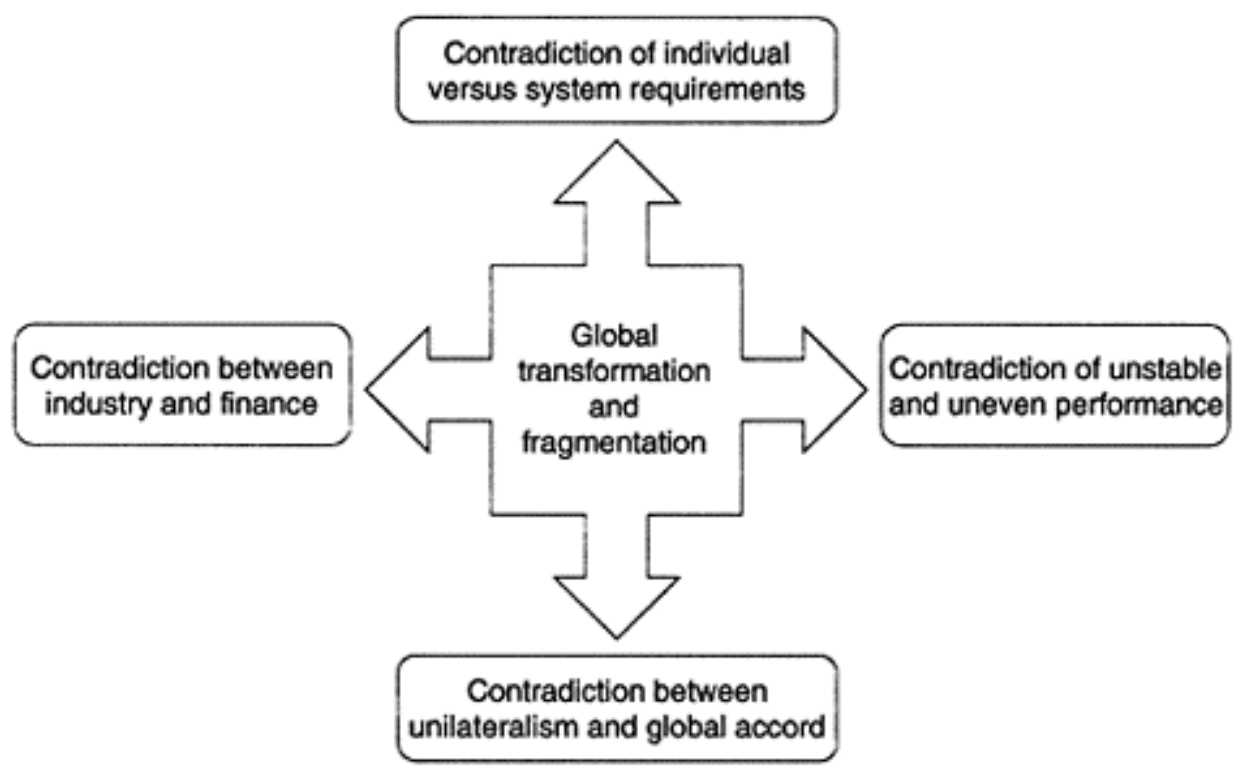

Figure 2.1 The dominant cultural contradictions of global capitalism.

(positive) stylized fact that it is a revolutionary system, one that seeks to create new innovations, penetrate new markets, create new industries, engender skill development, and cast aside fetters to its development wherever possible. Capitalism could not exist without the creative cultural process of continual innovation, competition, accumulation, and growth operating incessantly through time over many continents, nations, and regions. The cultural system and its agents seek opportunities for greater profitability, economic rents, and monopoly privileges while at the same time being subject to new methods and ways of doing business, with new agents and firms entering the process. Capitalism thus establishes itself by necessity as a global system in the sense of forever trying to caste aside barriers to its motion. It potentially enables people's livelihood to be enhanced as it propels material advance.

An inextricable part of these dynamic cultural elements is for the advancement of wants, desires, and needs of the population of consumers. As Doug Brown (2002) recognizes, the population as a whole is enculturated in the values of consumption, "being all they can be," enhancing their capabilities, climbing up the ladder of success and esteem. This is essential for the positive elements of capitalism to be enhanced and continually being advanced to a new level. People's desires need to be seen as insatiable, subject to limitless capacity for creative expansion. This is manifest in the creation of new fads, fashions, and style in the global marketplace, and the development of skills relevant to these market values. ${ }^{1}$

The very competitiveness of capitalism requires that people see this as being the progression of individualism, as skills, capabilities, potentialities, and new elements are developed to a higher level, and certain people are being actualized 
Table 2.1 Four engines of global cultural growth, 1980-2001

\begin{tabular}{llrrrr}
\hline & & \multicolumn{1}{c}{$\begin{array}{c}1980 \\
\text { \$billion }\end{array}$} & $\begin{array}{c}\text { \$1990 } \\
\text { \$billion }\end{array}$ & \multicolumn{2}{c}{$\begin{array}{c}2001 \\
\text { \$billion }\end{array}$} \\
\hline 1 & Foreign direct investment inflows (US\$billion) & 59 & 203 & 735 \\
2 & $\begin{array}{l}\text { High-tech manufacture exports (\% total } \\
\text { manufacture) }\end{array}$ & 9 & 15 & $23^{\mathrm{c}}$ \\
3 & Internet users (million) & 0.00 & 0.07 & 501 \\
4 & Cell phone owners (per 1,000 population) & 0 & $6^{\mathrm{b}}$ & 157 \\
\hline
\end{tabular}

Source: Adapted from UNCTAD (2002:4, 93); World Bank (2004).

Notes

a 1982.

b 1992.

c 2000.

to a greater extent. People need to travel to far away places, increase the quantity and quality of material possessions, become more hip than the next person, be better looking than they were, and be seen in the public eye wherever possible. These cultural norms are seen as part of the creative individual, despite the extent to which they are a product of the "social individual" (Davis 2003; Hodgson 2004). Table 2.1 provides a general indication of the trend of some of these positive elements over the past couple of decades, when foreign direct investment, high-tech exports, the internet, and cell phones grew rapidly from a low base.

These seemingly "positive"—or at least forward-looking—forces relate to the massive global (and regional) expansion of foreign investment, high technology manufactured exports, and internet and cell phone usage over the past decade or two. Indeed, these developments are the main ones that defenders of neoliberalism and globalization concentrate on to advance their argument that capitalism is a forward-looking and revolutionary system as far as technological and global investments are concerned. Furthermore, these variables are ones for which there are ample statistics and therefore it is relatively easy to make the case. This is an important point, that the detractors of neoliberalism and globalization often ignore or underplay, since many of them do not advance a holistic or general argument but concentrate on the negative aspects alone.

However, these forward-looking forces are inseparable from the destructive, uneven, unstable, alienating, inequitable forces that are part of the very process of global capitalism's dynamic. The dominant contradictions of capital lay in the very nature of capital itself. Being able to penetrate new markets, fashions, continents, and regions necessitates it to constantly expand geographically. But the spatial limits are considerable, including the coordinating process of global production and demand, the potential for an increase in the time of circulation, and for the inability to realize supply with demand. The need to create new branches of production leads to the demise of old firms, industries, and skills, and hence to periodic structural unemployment, bankruptcy, and transition lags from one sector to another. The need for sufficient profit requires 
investment, but in a system of persistent uncertainty and changing levels of confidence a drop in expected profit can lead to business cycle upswings and downswings of a potentially volatile nature. The workings of individual capitals may be in opposition to the needs of the system, since what may be good for an individual firm and person may not promote the public goods of confidence, stability, and trust.

This paradox of individual versus system requirements is a critical one for capitalism. For instance, profitability may be hindered if the general power of business is both much greater and also much less than that of workers. If business is too strong then wages may be too low, leading to insufficient demand for the system. But if business is too weak relative to workers, then wages may be too high as unemployment is historically low, leading to high costs of production (as well as greater demand). Both instances may lead to low investment and profitability via an increase in uncertainty for business as the climate for expansion is inhibited. System requirements may necessitate some degree of balance between capital and labor, and hence to the development of agreements that balance such power through historical time.

Capitalism also requires a continual dialectic of innovation-competition-innovation and so on ad infinitum. If innovations are not followed by a suitable measure of competition, then rent-seeking behavior on the part of firms, unions, or the state may lead to sclerotic practices that inhibit productivity and advancement. But if innovation is followed by too much competition such that profitability and expectations are diminished, then the system may be similarly inhibited leading to decreased accumulation and growth. Hence, some dynamic level of balance between innovation and competition is necessary for a relatively smooth flow of capital accumulation and growth through time. Such a balance is as likely as a "fluke" and hence capitalism is forever being subject to varying levels of stability and instability, leading to an unstable pattern of accumulation, innovation, and growth.

The greatest contemporary contradiction of global capitalism, however, is its inability to be revolutionary and path breaking in establishing economic performance and accumulation during the long wave downswing of the 1970s-2000s. The great successes of capitalism lead many to surmise that the negatives are well worth the effort if the positives are strong enough. However, apart from the emergence of long wave upswing in East Asia-a notable achievement-the positives have been especially weak since the advent of globalization and neoliberalism, not only in the advanced nations but also SubSaharan Africa, Latin America, Eastern Europe, and the Middle East. Global capitalism, therefore, over recent decades has been a failure in terms of its inability to reestablish reasonable levels of profitability, accumulation, productivity, and growth, the very things that it prides itself on. Much of the relevant data is shown in Table 2.2.

This data clearly shows that most growth figures were relatively high during the 1960s, and then consistently and successively declined through the 1970s, the 1980s, the 1990s, and the 2000s. Despite the growth engines of foreign investment, exports, and transnational firms, the overall economic performance of the world has become far worse. Clearly, the global corporate system has not succeeded in propelling greater profitability, investment, productivity, and growth during the 
Table 2.2 Global investment, productivity, profit and GDP, 1950s-2000s (decade annual averages)

\begin{tabular}{lrrrrrrr}
\hline & $1950 s$ & $1960 s$ & $1970 s$ & $1980 s$ & $1990 s$ & $2000-2002$ \\
\hline US 500 TNC profit rate & 7.71 & 7.15 & 6.30 & 5.30 & 4.02 & 3.30 \\
Real global investment growth rate $^{\mathrm{b}}$ & n.a. & 7.78 & 3.97 & 3.24 & 2.24 & 2.1 \\
Global industry value added growth $^{\mathrm{b}}$ & n.a. & n.a. & 3.36 & 2.59 & 1.92 & n.a. \\
Real per capita global GDP growth $^{\mathrm{b}}$ & n.a. & 3.19 & 2.11 & 1.27 & 1.05 & 1.00 \\
\hline
\end{tabular}

Source: Adapted from Fortune Magazine ${ }^{\mathrm{a}}$ (1960-2003); World Bank ${ }^{\mathrm{b}}$ (2004).

1970s-2000s; in fact, the experience is one of worsening performance. Even some of the positive forces of global capitalism have during the recent global recession of the early 2000s experienced a major slump: for instance, global foreign direct investment experiencing a 60 percent decline from US\$1,400 (2000) to US\$560 (2003) (UNCTAD 2004), illustrating the unstable nature of the system. Overall, then, there is no indication whatsoever that a new global mode of accumulation or social structure of accumulation (SSA) is being developed, and therefore capitalism's lack of effective positive dynamics is failing to propagate a new long wave upswing.

The contradictions are not simply manifesting themselves in the businessmaterial world, but also in the world of psychological well-being and environmental quality. The attempts over the past 20-30 years to regenerate its revolutionary spirit through unsuccessful means of enhancing productivity, accumulation, profit, and growth have become so extreme as to adversely affect the psychological state of the people and its nonhuman inhabitants. While real GDP (gross domestic product) per capita has declined over the past few decades, these figures understate the degree of lackluster performance. For instance, assessments of the index of sustainable economic welfare (ISEW)—or the genuine progress index (GPI) - has also declined, showing that GDP itself has overestimated the degree of well-being or performance. The ISEW (or GPI) is a composite measure of welfare that takes into account consumption, some nonmarket elements of (re)production, income distribution, unemployment and underemployment, levels of stress, crime, and pollution (Hamilton and Denniss 2000; Lawn 2001). Recent estimates for the ISEW are shown in Figure 2.2, for a group of nations in four continents.

We are interested in estimates of ISEW/GPI for nations in as many continents as possible. However, since no assessments have been made for nations in Asia and Africa, we must do with nations in Europe, North America, South America, and Oceania. Earlier we saw that the rate of economic growth of most nations and continents (except for Asia) has declined during the 1970s-2000s, as long wave down-swing set in. Figure 2.2 additionally shows that economic welfare also suffered substantially during the 1970s1990s, after rising during the 1950s and 1960s. 


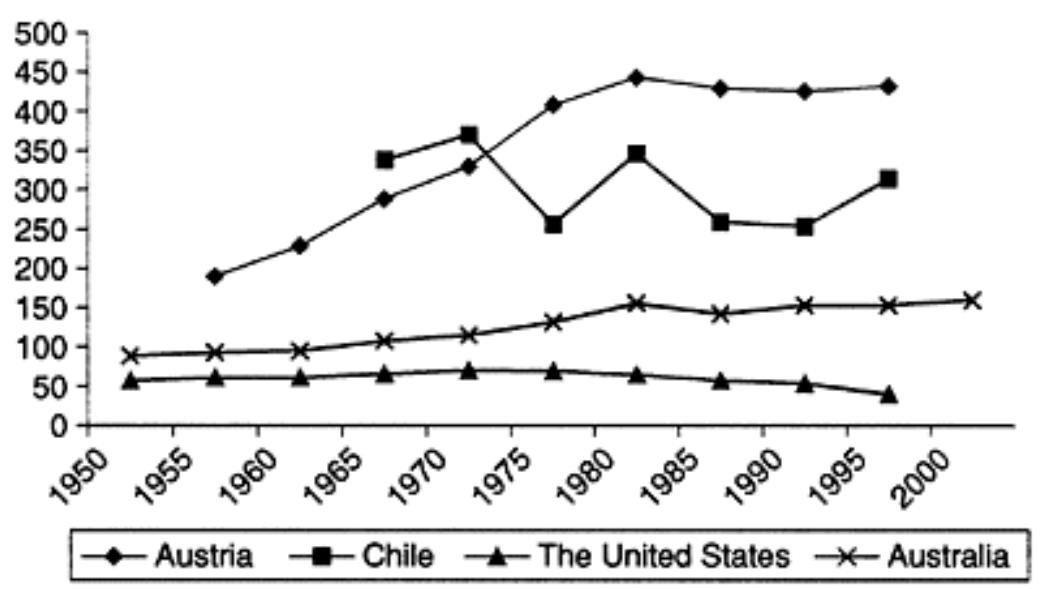

Figure 2.2 ISEW or GPI 1950-2000:4 nations.

Source: Adapted from FOE (2002).

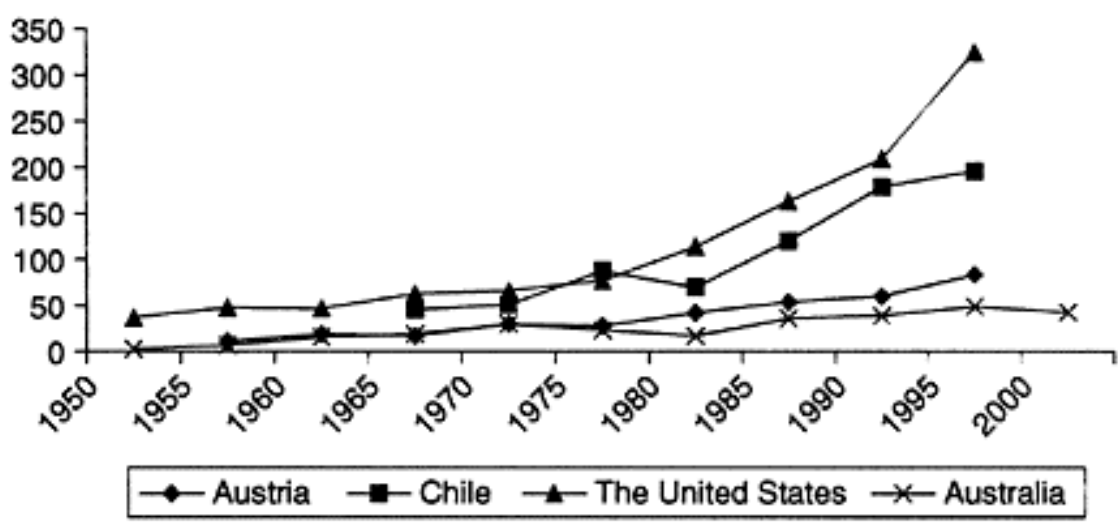

Figure 2.3 GDP excess over ISEW/GPI, 1950-2000:4 nations.

Source: Adapted from FOE (2002).

The reasons for this have been the pressure of extra work, the costs of pollution and stress, and the instability associated with the breakdown of family and community relationships (embodied in the ISEW results). Hence, the 1970-2000 period has been characterized by greater social and environmental costs and pressures and adversely affected the institutional and biospheric environments. The rate of GDP growth has declined since the 1970s. Yet, even the diminished GDP figures substantially overstate welfare, indicating that there has been a drop in welfare of a greater magnitude than the 
declining growth of GDP. Figure 2.3 compares GDP with ISEW and GPI over the past half a century.

The results of Figure 2.3 show that, during the 1970s-1990s, there has been between a moderate increase and an escalation in the extent to which GDP over-estimates the "psychic income" of nations: psychic income has to do with the "inflow of pleasant feelings," the "enjoyment of life," or "social well-being." Again, this is due to the costs of pollution, stress, overwork, greater inequality, and family/community breakdown. Not only has the long "wave upswing adversely affected GDP growth in most nations and continents, it has also adversely affected social well-being. The degree to which real GDP per capita does not reflect well-being is greater in the United States and Chile than in Austria and Australia, but the pattern of change is similar in all these nations.

\section{Contradictions of production-reproduction and industry-finance}

These general contradictions also link to more specific problems in the socioeconomic reproduction of global capitalism. Over the past 30 years as capitalism has become more global and neoliberal values have permeated the policy environment, specific cultural contradictions have manifest themselves in such a way as to expand and also inhibit the reproduction of the system. The first one relates to the contradictions analyzed by Daniel Bell, who recognized that the former business values of industriousness, humility, and trust have deteriorated somewhat as individualism, finance capital, and quick returns have become more significant. Indeed, since Bell wrote about this, these problems have exacerbated the instabilities of capitalism as long wave upswing during the 1950s-1970s has moved into downswing during the 1970s-2000s.

One of the major contradictions is that the rise of individualism, free markets, and globalization since the 1970s has led to a decline in trust. Trust is a critical factor not simply for the social cement of relationships in community but also for business networks and organizations. Trust reduces transaction costs as companies can depend upon the morality of informal agreements and instrumental relationships between people more than formal contracts and litigation. In just about all nations where neoliberal valuesprivatization, freer capital flows, labor market deregulation-have been expanded considerably recently trust has declined, often severely, as shown in Table 2.3.

The ISR World Value Survey is based on a random sample of interviews worldwide for "four waves of interviews," that is, the years 1981, 1990, 1995-1997, and 1999-2000. People were asked, for each of these "waves": “Can people be trusted?" The results shown are for the percentage of respondents who said "Yes,

$$
\begin{aligned}
& \text { Table 2.3 Levels of trust: the world and various } \\
& \text { nations, percentage who think people can be } \\
& \text { trusted, 1981, 1990, 1995-1997, 1999-2000 }
\end{aligned}
$$

\begin{tabular}{|c|c|c|c|c|c|c|c|c|}
\hline & World & $\begin{array}{l}\text { The United } \\
\text { Kingdom }\end{array}$ & $\begin{array}{l}\text { The United } \\
\text { States }\end{array}$ & $\begin{array}{l}\text { South } \\
\text { Africa }\end{array}$ & Argentina & Brazil & Russia & Poland \\
\hline 1981 & 38.4 & 43.3 & 40.5 & 29.0 & 26.1 & n.a. & n.a. & n.a. \\
\hline
\end{tabular}




\begin{tabular}{lllllllll}
\hline 1990 & 34.6 & 43.7 & 51.1 & 29.1 & 23.3 & 6.5 & 37.5 & 34.5 \\
$1995-$ & 24.3 & 29.1 & 35.9 & 15.4 & 17.6 & 2.8 & 23.2 & 16.9 \\
1997 & & & & & & & & \\
$1999-$ & 27.5 & 28.9 & $36 . .3$ & 13.2 & 15.9 & n.a. & 24.0 & 18.4 \\
2000 & & & & & & & & \\
\hline
\end{tabular}

Source: Adapted from the ISR (2000, 2004).

people can be trusted,” as opposed to "You cannot be too careful.” Eighty-two nations were used in the sample for 1999-2000. The results are fairly straightforward. For all nations (on average), trust declined from 38 percent (1981) to 35 percent (1990) to 24 percent (1995-1997) and then moderated a little to 28 percent (1999-2000). Results for the individual nations mostly followed this general trend, although with some variation; generally the decline was worse for nations that have embodied neoliberalism more than average. For instance, as the table shows, between 1981 and 1999-2000 (or 1995-1997 for some nations) a major drop in trust occurred in the "neoliberal" United Kingdom, South Africa, and Argentina, and a fairly significant drop in trust occurred in the "neoliberal” United States. A major drop in trust occurred over the years 1990 to 19992000 (or 1995-1997) in advancing "neoliberal” Russia and Poland, and a quite significant drop for "neoliberal” Brazil, which exhibits hardly any trust at all.

Part of the edifice affected by trust is the economy. Some studies have suggested that the most important aspect of social capital is "trust": to be able to trust that people will do what they say they will, that they will not exploit your good will, and that they will have some sympathy for your perspectives and problems. Trust is important in providing a basis for investment activity (Zak and Knack 2001), national and regional trade (Helliwell 2000), and corporate networks (Yeung 1998). Trust reduces transactions costs, increases the propensity to save and invest, and expands the income of its citizens. Theoretical and empirical studies (such as Yamagishi and Yamagishi 1994; Knack and Keefer 1997) have repeatedly shown a positive correlation and causal link between social trust and economic performance.

At the broader level, greater inequality and discrimination reduce trust (Kawachi 1997), while common language and customs enhance trust (Helliwell 2000). At the narrower level, in a cross-country survey for 41 nations (including the United States), Zak and Knack (2001) provide evidence that higher levels of trust expand investment and income through reducing moral hazard between principals and agents such as "investors" and brokers, which can be generalized to workers and capitalists, creditors and debtors, clients and consultants, insurers and insured, as well as retailers and customers. There was some degree of two-way causation between variables, but controlling for this it was found that a decline in trust in the order of 7 percent points resulted in an annual drop in investment of 1 percentage point; and a decline in trust of 15 percentage points resulted in a annual drop in growth of 1 percentage point. However, levels of trust have declined markedly throughout the world over the past two decades as the recent phase of globalization and neoliberalism have taken hold.

Another critical contradiction is that between industry and finance. As Marx, Veblen, Keynes, and Schumpeter recognized, there is a potential conflict between the industrial and financial aspects of capitalism in the global, regional, and national contexts. In 
certain phases of the business cycle, industry and finance can work in relative harmony with each other, especially in the recovery and moderate boom in the cycle. But especially as the highs of the business cycle emerge and euphoria sets in, problems start to emerge. Marx recognized that fictitious capital expands as credit finances an overvaluation in the stockmarket. Veblen realized that the pecuniary instinct begins to dominate industriousness within firms. Keynes emphasized a rapid expansion followed by a crash of prospective yield due to the excesses of upswing. And Schumpeter believed that when credit starts to finance general accumulation rather than innovation, the amplitude or instability of the cycle increases.

During the recent era of globalization-since the 1970s and 1980s-the contradiction between industry and finance has grown larger, leading to greater instability, uncertainty, and deeper recessions. The eight major financial crises of the 1994-2004 period-in Mexico (1994-1995), Asia (1997-1998), Russia (1998), Brazil (1999), Turkey (2001), Argentina (2001-2002), the United States, and ongoing crises in Japan-reinforced the need for fundamental change in the international financial architecture so as to embed economy within society. The crises of the 1990s-2000s, for instance, convinced many analysts and policymakers that global financial liberalization and innovation usually propel greater instability through endogenous credit and risk (see Spotton Visano 2004) and that there is a necessity for greater financial stability in the international financial architecture.

Markets need to be embedded in a system of suitable institutions, organizations, and legality (see Stiglitz 1999). As Little and Olivei (1999) conclude, "the characterization of some of these crises as financial panics has strengthened the case for effective international lender of last resort," and "the massive reversals in short-term capital flows that triggered these collapses have prompted calls for developing countries to reconsider the risks of open capital markets and the merits of capital controls." They argue that these crises have led many economists and policymakers to "question some of their most basic assumptions about the appropriate design of the international monetary system" (Little and Olivei 1999:53). ${ }^{2}$

There seems to be some agreement that emerging nations should be wary of liberalizing their capital account and financial system and cutting government spending without suitable institutions for protecting the poor, and monitoring the soundness, transparency, and prudential health of their banking systems (see Cooper 1999:17). ${ }^{3}$ Thus, some basic reforms that many agree on include "sound macroeconomic and financial policies: protecting the poorer segments of society, providing better and more fundamental bank supervision, proper accounting standards," and the like (Blinder 1999:58). The "blueprints" that the IMF (International Monetary Fund) adhered to, by advising austerity and cutting budgets, are considered to be misguided. As Eichengreen said:

What is unambiguous is that support for reform can be buttressed by strengthening the safety net for social groups most at risk Avoiding counter-productive conditionality may not be enough: in addition, positive steps to strengthen the safety net for those placed at risk...may be essential to maintain political support for reform. ${ }^{4}$ 
Similarly the contradiction between industry and finance has manifested itself in many national contexts, providing some linkages with the financial crises in the periphery and East Asia. Much of the hot capital that left Asia and elsewhere found itself in the United States via Europe through offshore banking centers (Wincoop and Yi 2000). On the back of an expanding high-tech and internet revolution, the US economy and the stockmarket boomed in the late 1990s into 2000s through a series of speculative bubbles in the Nasdaq-100, S\&P500, and so on in the financial indices. On the back of this was a series of outrageous accounting practices undertaken by many companies, including Enron, Global Crossing, and WorldCom. The bubble burst and deep recession emerged in internet-based economies as the failures of these practices and overexuberance led to high levels of uncertainty and instability. The contradiction between business and industry became clear as the extent of business infecting industry made it difficult for industriousness to make its own independent mark on the economy (see Chapters 7 and 8). ${ }^{5}$ The Japanese experience of successive deep recession and financial instability during 1990-2004 provides a similar lesson.

\section{Contradictions of unilaterialism and terrorism}

In recent years, neoliberalism has joined forces with a neo-conservative-unilateral approach to international relations by the United States and its principal allies, the United Kingdom and Australian governments. The decline of US hegemony into the 1970s and 1980s led the Reagan administration to heighten attempts at reestablishing its power in global politics. This seemed to succeed as the Eastern Block of “communism” went into abrupt decline in the late 1980s and early 1990s, leading most of the world to establish market relations in association with neoliberal policies. However, this led to problems in the global power system as the United States and its allies assisted leaders such as Saddam Hussein to come to power in Iran, the Mujahideen and Taliban in Afghanistan, while keeping its close links to the Saudi Court as well as Israel.

These alliances led to problems, since the Islamic radicals recognized that US support was purely strategic (for instance, in Afghanistan), not real diplomatic and political as such. This led to many contradictory relationships that have created considerable uncertainty in the global economy as risk has increased and global instability expanded into the twenty-first century. The major contradiction is that the decline in Soviet power created a vacuum that led to an expansion of the radical Islamic forces that the United States strategically encouraged in Afghanistan (and Iraq), and which eventually attacked US interests, culminating in the September 11, 2001 attacks in New York City and Washington, DC. This was followed by the October 2002 suicide attacks in Bali, those in May 2003 in Casablanca, May 2004 in Madrid, July 2005 in London, and of course the military opposition to the United States in Iraq. The power of the radical Islamic forces has dented US dominance in the global power system, and hence increased instability, risk, and uncertainty.

A number of related contradictions have expanded this instability. The rise in modern technology has enabled the radical militants to enhance their ability to question US power. The development of the internet has enabled them to communicate globally, and also to engage in cyber terrorism. Deregulation of international and domestic finance has 
enabled the radicals to create a global network of associations and groups with access to finance and resources. This in itself has led to some degree of regulation in the form of limits on open markets and on the global movement of people and armaments. The use of the media and the desire of national governments to promote nationalist sentiment has heightened social fear and intimidation vis-à-vis the "terrorist" attacks. In addition, the rise of unilateralism and the Doctrine of Preemptive War/Strike has led to some mistakes in US policy, the classic example being the invasion of Iraq, which was seen as an antiterrorism measure but in fact led to an expansion of radical Islamic movements as their enemy (the Hussein government) was deposed.

This cultural gulf between Western capitalism and Islamic radicalism has generated much conflict and instability in the global political economy. Three possible results may emerge from this antagonistic development. First, it could lead to greater conflict as neither side seeks to have empathy with the other, creating greater cultural disequilibrium. At present, this seems to be happening as the unilateral approach continues and the radical Islamic networks expand and develop. This promotes the continuation of long wave downswing through greater risk and uncertainty. The other options are a moderation in the conflict, and the less likely coming together of the cultural fabrics toward global community and cooperation. However this plays out in the future, though, at present it is generating considerable uncertainty and instability in various nations and regions, globally. (See Chapter 6 for more detail.)

\section{Conclusion}

This chapter started through the recognition of cultural contradictions being those that permeate critical aspects of the way of life of the people and the various economic agents and classes of global capitalism. Contradictions are positive and negative aspects of the social economy that are inextricably fused, but which vary in nature and intensity over historical time. The main contradiction is that global capital's dynamic and revolutionary aspects - such as the penetration of foreign direct investment, high-tech exports, and innovations - create destructive elements in the system. These destructive elements are fused with the positive and represent things destroyed in the process of accumulation, growth, and innovation. These include such things as skills, firms, cultures, and institutions that people rely on for their way of life. Global capitalism is an unstable system because the positive and negative elements are systematically created and destroyed, respectively, through evolutionary and transformational processes.

Then some specific attention was given to four main contradictions of global capitalism. The first is that as market processes and liberalization have been evolving globally the social cement of trust has declined throughout the globe, but more especially in "neoliberal" economies. The second is that finance has come to dominate industry, which periodically leads to speculative bubbles, deep recession, and corporate accounting fraud. The third is that most working people are working harder with greater stress to reestablish productivity and profit, while their well-being and natural capital deteriorates around them. And finally, the decline in Soviet-style "communism" led to a power vacuum which saw the expansion of radical Islam (initially supported by the United 
States) which has created much conflict between the United States (and their allies) and Islamic culture into the new millennium.

All of these contradictions adversely affect the accumulation dynamics of capitalism. As long wave downswing continues the very positive elements of capitalism decline through deteriorating economic performance. Sustainable welfare diminishes as the process of reestablishing growth adversely affects the environment, levels of stress, and the social fabric. The cultural contradictions of contemporary global capitalism are thereby considerable, and must be seen as systemic elements and holistic processes in institutional space and time. Successive chapters in this book explore these contradictory dynamics in more detail.

\section{Notes}

1 This chapter was presented at the annual meetings of the Association for Evolutionary Economics (AFEE) as part of the ASSA, San Diego, California, January 4, 2004. I wish to thank Richard Brinkman, Pamela Jackson, Reynold Nesiba, and Ron Stanfield for comments and/or encouragement on the issues dealt with in this chapter. An earlier and much shorter version of this paper was published in the Journal of Economic Issues (O'Hara 2004).

2 As Doug Brown (2004:209) says: "Yet in this new world of multiple subcultures, heterogeneity, diversity and the pastiche of life, fashion, style, conspicuous consumption, and emulation have found fertile ground. People are eager to embrace the latest fashion and the newest, trends ideas, subcultures, habits of the 'rich and famous,' and all that's hip. They are hungry to be like those they see in the media, to emulate the celebrities, to hang out with the latest hipsters."

3 Indeed, the IMF seems to have learnt the lesson and has fundamentally revised its austerity policies and blueprints in respect of the needs of the poor. Its recent Managing Directors speak of the IMF's recently acquired focus on the "fight against extreme poverty [which] has gained center stage in our programs," the importance of "civil society,” while the Enhanced Structural Adjustment Facility has become "transformed" into the new Poverty Reduction and Growth Facility (Camdessus 1999). Reducing poverty provides a powerful safety net that reduces the negative influence of debt, and hence moderates financial instability and crises.

4 As Little and Olivei say: Thus, "premature liberalisation runs the risk of leaving a developing country hostage to the whims of a handful of international investors, whose priorities need not coincide with a country's long term development goals" (Little and Olivei 1999:76). For further detail, see the analysis of Chapter 6 .

5 A number of largely similar proposals have emerged for a new global financial architecture (e.g. Blinder 1999; Cooper 1999; Eichengreen 2000; Woods 2000). There are some broad similarities between these proposals. First, there is agreement that hot capital flows have been a major problem. For instance, in the Asian crisis private capital flows increased from \$24 billion in 1990 to \$62 billion in 1996 and then decreased to \$20 billion in 1997 (Little and Olivei 1999:61). The main problem relates to hot capital flows that constitute endogenous, short-term sources of credit from overseas earmarked in US dollars. These flows increased the instability of the global system, manifesting by large booms followed by financial crises and deep recessions. The Asian boom-crisis and the US boom-slump are classic examples of these phenomena (a la Minsky). 


\section{References}

Bell, Daniel. (1976) The Cultural Contradictions of Capitalism, New York: Basic Books.

Blinder, Alan S. (1999) “Eight Steps to a New Financial Order,” Foreign Affairs, Volume 78, Number 5, pp. 50-63.

Brown, Doug. (2004) “Conspicuous Consumption, Fashion and Style in the Global Marketplace,” in Philip Anthony O’Hara (ed.), Global Political Economy and the Wealth of Nations:

Performance, Institutions, Problems and Policies, London and New York: Routledge, pp. 208221.

Camdessus, Michael. (1999) “Second Generation Reforms: Reflections and New Challenges,” Opening Remarks to the IMF Conference on Second Generation Reforms. November 8. www.inf.org/external/np/speeches/1999/110899.htm (accessed July 2, 2000).

Cooper, Richard. (1999) “A Tour of International Financial Reform,” Challenge, Volume 42, Number 4, pp. 5-28.

Davis, John. (2003) The Theory of the Individual in Economics, London: Routledge.

Eichengreen, Barry. (2000) "The Global Gamble on Financial Liberalisation: Reflections on Capital Mobility, National Autonomy, and Social Justice,” Ethics and International Affairs, Volume 13, pp. 205-226.

FOE (Friends of the Earth). (2002) Measuring Progress: International Indicators, London: Friends of the Earth. http://www.foe.co.uk/campaigns/sustainable_development/progress/ international.html (accessed December 13, 2003).

Hamilton, Clive and Richard Denniss. (2000) Tracking Well-being in Australia: The Genuine Progress Indicator 2000, Discussion Paper No. 35, Canberra: The Australia Institute.

Helliwell, J. (2000) "Balanced Growth: The Scope for National Policies in a Global Economy,” in M.Richardson (ed.), Globalisation and International Trade Liberalisation, Cheltenham, UK and Northampton, MA: Edward Elgar.

Hodgson, G.M. (2004) Reconstructing Institutional Economics: Evolution, Agency and Structure in American Institutionalism, London and New York: Routledge.

ISR (Institute for Social Research). (2000) World Value Surveys, 1981, 1990, 1995-1997, Ann Arbor, MI: University of Michigan (purchased from Australian National University, Research School of Social Sciences).

ISR. (2004) World Value Surveys, 1999-2000, Ann Arbor, MI: University of Michigan (purchased from Australian National University, Research School of Social Sciences).

Kawachi, Ian. (1997) “Social Capital, Income Inequality, and Mortality” The American Journal of Public Health, Volume 89, Number 8, pp. 1187-1193.

Knack, S. and P.Keefer. (1997) "Does Social Capital Have an Economic Payoff? A Cross-country Investigation”, Quarterly Journal of Economics, Volume 112, Number 4, pp. 1252-1288.

Lawn, Philip. (2001) Toward Sustainable Development: An Ecological Economics Approach, Boca Raton, FL: Lewis Publishers.

Little, Jane Snedden and Giovanni P.Olivei, (1999) "Why the Interest in Reforming the International Monetary System,” New England Economic Review, September/October, pp. 5384.

Mayhew, Anne. (1994) “Culture,” in Geoffrey M.Hodgson, Warren J.Samuels, and Marc R.Tool (eds), The Elgar Companion to Institutional and Evolutionary Economics, Aldershot: Edward Elgar, pp. 115-119.

O’Hara, Phillip Anthony. (2001) “Contradiction,” in Phillip Anthony O’Hara (ed.), Encyclopedia of Political Economy, London and New York: Routledge, pp. 140-143, Paperback Edition.

O’Hara, Phillip Anthony. (2004) “Cultural Contradictions of Global Capitalism,” Journal of Economic Issues, Volume 38, Number 2, June, pp. 413-420. 
Spotton Visano, Brenda. (2004) “Financial Crises, Crashes and Speculative Bubbles,” in Phillip Anthony O'Hara (ed.), Global Political Economy and the Wealth of Nations: Performance, Institutions, Problems and Policies, London and New York: Routledge, pp. 225-244.

Stanfield, James Ronald. (1995) Economics, Power and Culture: Essays in the Development of Radical Institutionalism, New York: St. Martin’s Press.

Stiglitz, Joseph. (1999) “Quis Custodiet Ipsos Custodes?” Challenge, Volume 42, Number 6, pp. 26-67.

UNCTAD (United Nations Conference on Trade and Development). (2002) World Investment Report 2002: Transnational Corporations and Export Competitiveness, New York and Geneva: United Nations.

UNCTAD. (2004) World Investment Report 204: The Shift Towards Services, New York and Geneva: United Nations.

Wincoop, Eric van and Kei-Mu Yi. (2000) "Asia Crisis Postmortem: Where Did the Money Go and Did the United States Benefit?” FRBNY Economic Policy Review, Volume 6, Number 3 (September), pp. 51-70.

Woods, Ngaire. (2000) "The Challenge of Good Governance for the IMF and the World Bank Themselves,” World Development, Volume 28, Number 5, pp. 823-841.

World Bank. (2004) World Development Indicators online Database (Subscription), http://www.worldbank.org/data (accessed August 12, 2004).

Yamagishi, T. and M.Yamagishi. (1994) "Trust and Commitment in the United States and Japan," Motivation and Emotion, Volume 18, Number 2, pp. 129-166.

Yueng, Y. (1998) Hong Kong Transnational Corporations in South East Asia, London and New York: Routledge.

Zak, P.J. and S.Knack. (2001) “Trust and Growth,” The Economic Journal, Volume 111, Number 470, pp. 295-321.

\section{Further reading}

Brown, Doug. (2002) Insatiable is Not Rational, Westport, CT: Praeger Press.

Fortune Magazine. (1956-2003) “Profit Data,” Fortune Magazine (various issues).

Kawachi, I., B.P.Kennedy, K.Lochner, and D.Prothrow-Smith. (1997) “Social Capital, Income Inequality, and Mortality,” American Journal of Public Health, Volume 87, Number 9, pp. 1491-1498.

Lawn, Philip. (2003) "A Theoretical Foundation to Support the Index of Sustainable Economic Welfare (ISEW), the Genuine Progress Indicator (GPI) and other Related Indexes,” Ecological Economics, Volume 44, Number 1, pp. 106-188. 


\section{3 \\ A global neoliberal social structure of accumulation?}

\section{Introduction}

According to adherents of the social structure of accumulation (SSA) approach to political economy, sustainable long-term growth and accumulation requires a set of suitable structures for promoting public goods or system-functions that transcend market or individual activities. These system-functions are carried out, according to Martin Wolfson (1994), primarily through institutions that promote social stability, conflict resolution, and long-term profitability. In his original formulation of the SSA theory, David Gordon (1980) recognized that a large number of institutions are necessary for sustainable growth, including systems of transport, industrial relations, finance, family formation, material resource supply, infrastructure, labor supply, and government. The social requirements for sustained accumulation are multifarious and complex, necessitating widespread structures promoting productivity and demand.

Western nations thus are said to have experienced a long wave upswing in the 1950s and 1960s. Deep recessions and major financial crises were absent, and growth was quite strong for the 2 or 3 decades after the Second World War. These results were thought to be the result of a number of institutional structures. However, these institutional arrangements are said to have faltered from the 1970s to the 1990s (at least) as contradictions within these structures led to greater uncertainty, conflict, and instability. A long wave downswing thus emerged, with periodic deep recessions, financial crises, and much slower economic growth.

Empirical studies of the postwar era by SSA analysts have tended to delimit this analysis somewhat. For instance, Bowles et al. (1990) suggest that the "postwar corporate system" upswing in the United States (and other Western nations) during the 1950s and 1960s was based on four main institutional spheres-Pax Americana, a capital-labor accord, a moderation of competition, and the Keynesian-welfare state. Two other key institutional spheres have been added, a system of regulated finance (Wolfson 1994) and family-community formation (O’Hara 1995, 2004a). ${ }^{1}$

The state has impacted all of these spheres. For instance, US hegemony was inextricably linked to military spending and the role of the state in facilitating sustainable growth and accumulation both during and after the Second World War. The state contributed to the capital-labor accord by facilitating legal and industrial relations outcomes that enhanced agreement. And the state was implicated in other social structures of accumulation (SSAs) through systems of corporate law, financial regulation, and family assistance packages. But the main state functions were the Keynesian-welfare policies that dominated the 1950s and 1960s in most advanced capitalist economies. This 
included automatic and discretionary stabilizers; a full package of welfare benefits such as unemployment insurance, pensions, and sickness benefits; and an array of military, legal, and regulatory arrangements (Bleaney 1985). Indeed, during the postwar era, the state became the dominant institutional player. Nonetheless, the contribution of companies, unions, and families to governance processes was quite strong (O'Hara 2000).

According to SSA arguments, the Keynesian-welfare state contributed to this long wave upswing by enhancing stability, conflict resolution, and profitability. Stability was promoted by government spending raising the floor of the business cycle and thereby reducing uncertainty. Conflict resolution was provided by reducing antagonism between capital and labor, finance and industry, and national and global economies. And profitability was stimulated by the provision of government contracts with the private sector in areas such as military, infrastructure, and communications. ${ }^{2}$

However, in the late 1960s and early 1970s, the state was said to inhibit long-term accumulation through greater regulations, higher taxes, red tape, long policy lags, and incompetence. The Vietnam War contributed to stagflation and declining US hegemony; welfare policies led to a drop in the cost of job loss; the search for higher values questioned the work ethic; and long-term industrial profit was inhibited by higher taxes and regulations. Many non-state institutions contributed to the long wave downswing as well, according to the SSA argument, including the maturation of systems of technology associated with the product cycle of consumer durables, a reform movement that questioned many of the values of capitalism, and developments in Europe and Asia that challenged US power (Bowles et al. 1990).

Typically, when a long wave downswing begins, forces try to resurrect the conditions for long-term growth and accumulation. While some of these are conscious and reasoned responses, many are tantamount to "groping in the dark," since the prerequisites of an upswing are by no means obvious and few policymakers recognize the operation of long wave processes. Central to the struggle for renewed stability and profitability since the 1970s has been an attack on the Keynesian-welfare state and a rise of free-market ideology. Since the late 1970s, this economic philosophy has had a strong influence on policy in most nations of the world.

After some earlier trends along these lines, from the late 1970s and early 1980s, the Thatcher and Reagan revolutions questioned the welfare state as a way of regulating and moderating economic fluctuations. This led to the rise of neoliberalism, a conservative form of economic policy and governance that relies on the free market and individual initiative. Neoliberalism advocates the sale of state enterprises, less government spending, reduced taxes, and fewer regulations on business. During the 1990s, and continuing into the new millennium, the ideology and practices of neoliberalism became dominant worldwide.

SSA studies have tended to take a national perspective on the problem. But in the current global age we need to take a more international approach. Since national economies are becoming more open, it is critical to explore public-goods functions in a wider context than the national economy. This is not to argue that globalization has destroyed national economies; indeed, the evidence suggests that the global tendency is only partial. Nevertheless, it is no longer desirable to take a purely national view of these matters. ${ }^{3}$ Hence the importance of a Global System of Power and Accumulation, 
introduced in Chapter 1. There are four main sub-systems to this global system: the neoliberal system of governance, the transnational corporate system, the global mode of regulation (MOR), and the unilateral/unipolar system against terrorism and rogue states. This chapter sets out the main contours of the global system of neoliberalism and whether it currently operates as an effective SSA. ${ }^{4}$

Much recent debate has centered on whether a long wave upswing is emerging due to neoliberalism, and also about how to generate a new long wave upswing. ${ }^{5}$ The first section sets out the main principles and practices of neoliberalism. The Following section examines how neoliberal policies and practices have affected economic activity, particularly economic growth, productivity, financial stability, and inequality. The last main section explores the impact of neoliberal fiscal and monetary policies.

\section{The current neoliberal system of governance}

Six dominant trends associated with neoliberal state institutions have been operating in most nations and international institutions. First, there is a belief in small government. ${ }^{6}$ The neoliberal consensus posits the need to reduce the size of government to a far smaller percentage of GDP (gross domestic product) than was typical in the postwar era. It seeks to privatize government enterprises, reduce red tape, and increase corporate selfgovernance. One justification for this is that governance functions can be performed by other institutions such as corporations, non-government organizations, and communities. A second justification is that there has been too much governance, especially during the 1960s and early to mid-1970s, and that a decline in quasi-public goods functions is in order.

Most nations have attempted to sell off public utilities such as gas, water, telecommunications, and electricity to the private sector. They have looked to private corporations to administer prisons and created private sector universities where (in some cases) there was none before. They have also looked to the private sector for cleaning, security, and even research in government departments. Legislation has attempted to reduce red tape; to cut business paperwork and administrative costs required by government for information, regulatory, and policy purposes. And attempts have been made to increase the extent to which private sector corporate watchdogs and corporations themselves administer and oversee company practices concerning auditing, accounting, and financing. This remains true in the first decade of the new century despite a backlash against this in the light of US corporate scandals such as Enron and Worldcom.

Second, the wave of neoliberal policies enacted from the 1970s to the 1990s attempted to deregulate the domestic financial system through a series of institutional changes. Controls over interest rates on checking accounts, mortgages, and corporate and consumer loans were ended. This was based on the belief that controls hurt those who can least gain access to finance by reducing the overall availability of finance. Monetary authorities also ceased to use variable reserve requirements to control the money supply. Instead, open market operations (the buying and selling of mostly government securities) became the established way of controlling economic activity. Moreover, monetary policy became the dominant discretionary means used by many governments to affect economic activity in the pursuit of stable prices and GDP growth. 
The third plank of neoliberalism has been to deregulate the labor market through reforming industrial relations. Radical, liberal, and conservative economists all believed that during the 1960s and early to mid-1970s workers expanded their level of power relative to capital, that the wage share of national income had risen to high levels, and that productivity declined markedly. The neoliberal response to this was to try to increase the power of capital by reducing minimum wages, expanding workplace agreements, including privacy clauses in union voting, encouraging nonunion and no-strike clauses in labor agreements, and increasing the flexibility of wages and working conditions. The main objective of these policies was to reestablish the power, profitability, and viability of individual corporations so as to increase growth and accumulation. ${ }^{7}$

The fourth plank of neoliberalism is to free up international capital so that the global circuit of business can expand. This was done by promoting the free movement of money, production, and trade worldwide. In the mid-1990s, the World Trade Organization (WTO) was established to reduce tariffs and subsidies so that not only products but also services could be traded more freely in the global economy. The protection of intellectual property rights was also enhanced by including China and the former Eastern Block in the system of agreements. And some minimal attempts were made to include underdeveloped nations by putting agricultural reform on the agenda. These multilateral agreements were designed to enhance free trade regionally and globally. Several regional economic alliances were formed as well, including the North American Free Trade Area, the European Union, Asia-Pacific Economic Cooperation, and the fledgling Free Trade Area of the Americas.

Just as critical to the neoliberal agenda has been the freer movement of capital (especially in developed nations) through flexible exchange rates, reducing capital controls, and more uniform taxation at lower rates (especially for corporations and the rich). These changes let money capital move more freely to those areas and activities with the highest rate of return and where innovations could be implemented without hindrance. The essence of capitalism is said to be inherent change, dynamic innovation, and a world without barriers to doing business. Only in a system free of restrictions to the movement of money capital could investment-it was thought-enhance global profit and growth. Reduced taxation and greater tax uniformity is consistent with this enhanced free flow of foreign and domestic capital.

A fifth plank of neoliberalism concerns international relations. With the supposed decline of US hegemony in the late 1960s and the 1970s, many believed that global public goods could best be established by military policies and foreign relations aimed at a new global system of power. The new policy aims to reestablish US imperial power in the interests of global corporations and finance capital. Hence, in the post Cold War era the neo-conservatives in Washington and its allies sought to attack (at least verbally) antiUS regimes in Iraq, Iran, and North Korea (the "axis of evil”), as well as (in practice) terrorist forces such as the Taliban, al Qaida, and Palestine liberation groups such as Hamas (via the Israeli military). Renewed US hegemony is thought to help establish a new pro-corporate global system with stable property rights and greater security. Such a system, to a considerable degree, transcends the United Nations, certain global protocols (such as the Kyoto Agreement on climate change), and the International Criminal Court, in favor of US power and authority. 
The same neoliberal principles are imposed on Africa, South and Central America, and the underdeveloped areas of Asia. It is thought that development will only occur where flexible markets and free trade are allowed to stimulate the entrepreneurial spirit. No major stimulus is needed to promote development except the freedom of private capital to emerge spontaneously from an environment conducive to private initiative and accumulation. In short, for the sixth plank, the neoliberal development philosophy is no different from neoliberal general philosophy. So, a uniform policy framework is imposed on all nations, regardless of history, government, and culture. It is not necessary to understand each nation's experience, so the argument goes, since "one size fits all.” A system of individual and corporate property rights is necessary to lay the groundwork for business enterprise. A system of contract, accounting, and private rules and guidelines provides the basis for a spirit of enterprise. Regulations on business need to be dismantled for the bourgeoning business class to emerge and become dominant.

These six planks of neoliberalism form the basis of the governance measures that emerged in the world over the past quarter century. They have been responses to the deteriorating global environment of the 1970s. The question is whether these policies have had a positive impact on the economic performance of national economies. It is also critical to assess the potential of such policies to enhance performance in the future. (In Chapter 10 we examine the philosophy and policy program of a post neoliberal system of governance.)

\section{The impact of neoliberalism}

As neoliberal policies have been dominant since the late 1970s, we should see some positive impact on the global economy if it is an effective governance system. Table 3.1 looks at the global record of economic growth and accumulation from a long-term perspective.

\section{Table 3.1 Growth of real GDP per capita in the global economy}

\begin{tabular}{|c|c|c|c|c|c|c|}
\hline & World & $\begin{array}{l}\text { Advanced } \\
\text { capitalist nations }\end{array}$ & $\begin{array}{l}\text { Latin } \\
\text { America }\end{array}$ & Africa & $\begin{array}{l}\text { Eastern } \\
\text { Europe }\end{array}$ & $\begin{array}{l}\text { Asia (excluding } \\
\text { Japan) }\end{array}$ \\
\hline $\begin{array}{l}1950- \\
1973\end{array}$ & 2.93 & 3.72 & 2.52 & 2.07 & 3.49 & 2.92 \\
\hline $\begin{array}{l}1973- \\
2001\end{array}$ & 1.43 & $1.98^{\mathrm{a}}$ & 1.08 & -0.38 & $-1.10^{\mathrm{a}}$ & $3.54^{\mathrm{a}}$ \\
\hline $\begin{array}{l}1980- \\
1990\end{array}$ & 1.43 & 2.67 & -0.77 & -1.09 & 1.60 & $6.8^{\mathrm{b}}$ \\
\hline $\begin{array}{l}1990- \\
2001\end{array}$ & 1.13 & $1.77^{\mathrm{a}}$ & 1.64 & -0.24 & $-2.26^{\mathrm{a}}$ & $4.2^{\mathrm{b}}$ \\
\hline
\end{tabular}

Source: Adapted from Maddison (2000:126, 129); World Bank (2003); IMF (2002:172).

Notes

a $1973-2000$ or $1900-2000$. 
b Newly industrialized Asian nations only.

These figures show that the high growth rates in the "golden age" of the 1950s through to the early to mid-1970s were not reestablished during the "neoliberal era" (as Maddison calls it) of the mid to late-1970s onward through the 1980s, 1990s, and 2000s. Instead, growth has remained relatively subdued since the mid-1970s for the "world," advanced capitalist nations, Latin America, Africa, and Eastern Europe (including Russia). Moreover, the record of most nations during the 1990s-2000s was worse than during the first full decade of neoliberalism in the 1980s. The big change in the 1980s-2000s is the rising growth of certain newly industrialized Asian nations, due to changes in the centerperiphery structure of the world-system. However, for the entire global economy there has been little or no success in promoting growth since the early 1970s. The shift in growth from the center to the East-Asian former periphery and the drop in global demand are the basis of the decline in advanced nations and the global economy. ${ }^{8}$

A similar record holds for productivity growth, as Table 3.2 shows. Most major developed nations had higher rates of productivity growth during the 1960s (and 1950s) compared to the years after 1970. The record also supports the conclusion that productivity growth was lower in the 1980s than in the 1970s, and lower in the 1990s than in the 1980s. Again, these declines for advanced nations occurred in tandem with productivity increases in parts of Asia (see Bloch and Tang 2004), but the latter expansions have not been large enough to increase average world productivity growth. Thus, there is no evidence that neoliberal policies have been able to improve economic performance and counter the long wave downswing. ${ }^{9}$

The evidence regarding financial instability is also clear, and fails to support the neoliberal policy agenda. Comparing the upswing of 1945-1971 with the downswing of 1973-1997, banking and currency crises increased markedly over time. Financial crises became more pronounced in the 1980s than in the 1970s, and more pronounced in the 1990s than in the 1980s, as Table 3.3 shows. There was only 1 banking crisis during the long wave upswing of 1945-1971, but 26 during the downswing of the 1970s-1990s. There were 37 currency crises during the upswing, but 86 during downswing. Overall, the probability, number, the output loss, and the recovery time associated with crises were all much greater during the

Table 3.2 Productivity growth in the manufacturing sector: 1960-1999 (annual rate of change)

\begin{tabular}{|c|c|c|c|c|c|c|c|c|c|}
\hline & $\begin{array}{l}\text { United } \\
\text { States }\end{array}$ & & $\begin{array}{l}\text { United } \\
\text { Kingdom }\end{array}$ & & Japan & Canada & France & Germany & Italy \\
\hline $\begin{array}{l}1960- \\
1970\end{array}$ & & 3.7 & & 4.3 & 17.1 & 4.5 & 9.7 & 7.8 & 8.7 \\
\hline $\begin{array}{l}1970- \\
1980\end{array}$ & & 2.0 & & 2.5 & 6.8 & 2.7 & 5.5 & 4.8 & 7.4 \\
\hline $\begin{array}{l}1980- \\
1990\end{array}$ & & 1.8 & & 5.7 & 4.9 & 2.7 & 4.0 & 2.8 & 4.4 \\
\hline $19.90-$ & & 2.0 & & 2.2 & 3.2 & 2.1 & 3.6 & 2.8 & 2.2 \\
\hline
\end{tabular}


1999

Source: Adapted from US Department of Labor, Monthly Labor Review (September 2000:95, 101; June 2001).

Note

US data is for the business sector as a whole (which is typically half the value of that for the manufacturing sector).

Table 3.3 Banking and currency crises in the world: 1945-1997 (21 nation sample)

\begin{tabular}{lrrrrrr}
\hline & $\begin{array}{l}\text { Probability of } \\
\text { crises (\% point } \\
\text { chance) }\end{array}$ & $\begin{array}{l}\text { Number of } \\
\text { currency } \\
\text { crises only }\end{array}$ & $\begin{array}{l}\text { Number of } \\
\text { banking } \\
\text { crises only }\end{array}$ & $\begin{array}{l}\text { Twin } \\
\text { crises } \\
\text { only }\end{array}$ & $\begin{array}{l}\text { Output loss } \\
\text { of crises (\% } \\
\text { points of } \\
\text { growth lost }\end{array}$ & $\begin{array}{l}\text { Recovery time } \\
\text { (years for } \\
\text { output to } \\
\text { normalize) }\end{array}$ \\
\hline $\begin{array}{l}1945- \\
1971\end{array}$ & 7.04 & 37 & 1 & 1 & 5.24 & 1.78 \\
$1973-$ & 9.68 & 86 & 26 & 27 & 7.77 \\
1997
\end{tabular}

Source: Adapted from Eichengreen and Bordo (2002).

time of neoliberalism than beforehand. The real problem is the emergence of twin crises (currency and banking crises), which were only 1 in number during long wave upswing, but 27 during the downswing when neoliberalism was strong.

Little and Olivei (1999) also document the financial crises of the 1990s being greater in number and intensity than those during the 1980s. Such crises have continued into the new millennium, especially in Argentina, Uruguay, and Brazil. During the early 2000s, many nations of the world experienced a deep recession and financial malaise, including three of the biggest nations - the United States, Japan, and Germany. Herrero and Rio (2003) provide specific data comparing the domestic banking crises of the 1970s with those of the 1980s and 1990s, which is summarized in Table 3.4. The pattern here is for an increase in the number of banking crises internationally as the 1970s moved into the 1980s and further into the 1990s. As the 1970s moved into the 1980s conditions led to an expansion of banking crises in the developing and industrial worlds. And as the 1980s moved into the 1990s a further boost to crises emerged through instability in the developing and transitional economies. During long wave downswing, new conditions emerged in successive decades to add more complex patterns to the fabric of financial instability.

The crises of the 1990s convinced many analysts and policymakers that financial liberalization and innovation generates greater instability through 
Table 3.4 Domestic banking crises in the world: 1970s, 1980s, 1990s (percent of all crises during 1970-1999)

\begin{tabular}{lrrrr}
\hline & $1970 s$ & $1980 s$ & $1990 s$ & $1970 s-1990 s$ \\
\hline Industrial nations & 4 & 11 & 11 & 26 \\
Developing nations & 2 & 25 & 28 & 55 \\
Transitional nations & 0 & 0 & 20 & 20 \\
Percent & 6 & 35 & 59 & 100 \\
\hline
\end{tabular}

Source: Adapted from the data in Herrero and Rio (2003).

endogenous credit and debt risk (see Spotton Visano 2004) and that the experience of the 1990s requires greater financial stability in the national and global financial architecture. The Russian collapse of confidence in the 1990s taught many that a "cold turkey" approach to market-based reforms is not sufficient. Rather, markets need to be embedded in a system of suitable institutions, organizations, and laws (see Stiglitz 1999). The International Monetary Fund (IMF) has responded to these instabilities and criticism of neoliberal policies by creating poverty relief funds and quasi-international lender of last resort facilities. The poverty relief measures are seen to be necessary because safety nets are critical to maintaining average living standards during crises and contagions. But we need real international lender of last resort facilities, and a policy that places the onus of adjustment on surplus current account nations.

Last, what is the record for global inequality? This is a very controversial subject, but the basic evidence is fairly clear, as Figure 3.1 shows. Global inequality has increased significantly during the late twentieth century, from a log variance of GDP of under 2.0 (1960) to around 2.4 (1975) to a high of 2.8 (1999). Much of the greater inequality is among nations, as incomes in Africa and (to a lesser extent) Central and South America have fallen relative to advanced and some emerging nations. Some of this inequality is due to the process of uneven development resulting from neoliberal policies, and some is due to nations falling behind for failing to join the global economy in a substantive fashion. However, inequality has also increased within the highly industrial and emerging nations and among other nations and regions that have put into practice neoliberal-type policies, as shown in Table 3.5.

The leading neoliberal nations in the advanced Western world are the United States, the United Kingdom, Australia, and New Zealand. The leaders in Latin America have been Brazil, Argentina, and to some degree Chile. Nations of Eastern Europe-along with China-have undertaken substantial privatization and reduction in government services that draws inspiration from neoliberal policies. There has been a substantial increase in inequality (proxied in Gini Coefficient) for these nations that have embraced neoliberal governance practices over the past two decades or more, but usually less inequality for those nations that did not fully embrace neoliberalism (Galbraith and Kum 2003). Steven Pressman (2002) explains much of the world's gender inequality as being due to neoliberal policies as well; the failure to assertively assist poor families. 


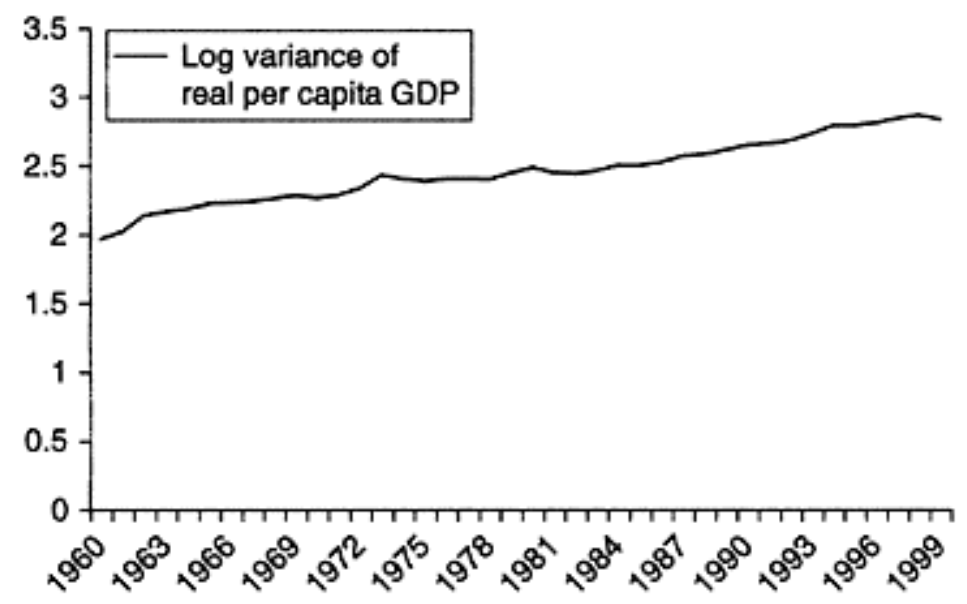

Figure 3.1 World inequality, 19601999.

Source: Dutt (2004).

Table 3.5 Inequality under neoliberal rule: Gini coefficient (1968-2002)

\begin{tabular}{|c|c|c|c|c|}
\hline & 1970 s [or 1960s] & $1980 s$ & $1990 s$ & Near 2000s \\
\hline The United States & $0.39[70]$ & $0.40[80]$ & $0.46[94]$ & $0.44[01]$ \\
\hline The United Kingdom & $0.26[75]$ & $0.29[85]$ & $0.32[95]$ & 0.36 [99] \\
\hline New Zealand & 0.24 [79] & $0.26[83]$ & $0.30[90]$ & 0.33 [97] \\
\hline Australia & $0.32[68]$ & $0.32[81]$ & $0.44[94]$ & 0.45 [99-00] \\
\hline Brazil & $0.55[74]$ & $0.56[87]$ & $0.61[98]$ & $0.63[02]$ \\
\hline Mexico & n.a. & n.a. & $0.52[96]$ & $0.55[00]$ \\
\hline Chile & $0.46[71]$ & $0.53[80]$ & $0.57[98]$ & $0.57[00]$ \\
\hline Eastern Europe & n.a. & $0.28[88]$ & 0.35 [97] & n.a. \\
\hline China & n.a. & 0.20 [87] & 0.28 [95] & $0.45[01]$ \\
\hline
\end{tabular}

Source: Adapted from UNDP (2004); EU (2004); King (2003); ABS (2003); OECD (2002); Deninger and Squire (2003); Galbraith (2003); Smeeding (2001); Milanovic (1998).

Greater income inequality performs a critical function for neoliberal capitalist economies by providing a basis for invidious distinctions and demonstration effects. The pressure to "keep up with the Jones'” is a foundational element of the neoliberal age. Conspicuous consumption and display, as well as status and power, inspire those of working age to emulate those higher up in the class system. This is important for keeping consumption 
spending high through greater debt, as those with lower incomes must spend a greater fraction of their income to compete in the fashion and style market.

\section{Neoliberal fiscal and monetary policies}

So far we have found that the rise of neoliberalism has not led to a turnaround in economic performance. Now we explore the effectiveness of state-sector governancefiscal and monetary policy. What impact has the move to privatize government enterprises, cut government programs, balance budgets, and reduce red tape had on economic performance? Two main issues are at stake: what influence has a change in fiscal stance had on economic performance, and what type of state programs are likely to enhance investment, economic growth, and development.

Neoliberalism has shifted state spending toward transfer payments and away from the purchase of goods and services. In the United States, for instance, the ratio of total government spending to GDP has remained fairly stable at around 32 percent from the 1950 s to the 1990s. But the ratio of government purchases has declined from 32 percent in the early 1950s to 18 percent in 1997, while transfer payments have risen from 32 to 46 percent over the same period (Weber 2000). A similar pattern emerges for other advanced nations. This change occurred during the 1970-1990 period when there had been a marked reduction of GDP growth and greater financial instability. Weber (2000) demonstrates that the two tendencies (changing spending patterns and lower growth) are inextricably related, since the change in government spending accounts for the entire slowdown and more. The change in policy from economic activism to passivism, from actively stimulating economic activity to supplementing income through pensions, subsidies, and other benefits, has had a negative impact on growth and accumulation. The wave of privatization, as well as the decline in public capital, reduced the extent to which government spending expanded GDP, and so contributed to the long wave decline in growth and accumulation.

Numerous studies from around the globe point to the same conclusion. Research supports a change in policy toward building public capital, such as infrastructure, education, telecommunication, and utilities; toward an activist state with a program of government enterprises that will enhance the capital stock of nations. Using data from the Penn World Tables, Miller and Tsoukis (2001:1125) found that "on the whole, government investment has been severely suboptimal [recently and]...scope exists for greater productive expenditures by the government sector.” In a study of Greece, Ireland, Spain, and Portugal, Laopodis (2001) suggests that nonmilitary public spending on education, infrastructure, and health has a net crowding in effect on private investment and GDP, and that public capital is currently being under-provided. In a study of Malaysia, Ibrahim (2001) concludes that state spending on transport, telecommunications, education, and health has a net crowding in effect on private investment. Ibrahim finds that tax-based financing crowds out, while debt-based financing tends to crowd in, private investment.

Table 3.6 illustrates the trend of real government fixed capital formation as a percent of GDP for the main neoliberal OECD nations over the period 1960-2000. The trend since the 1970s or 1980s in the United States, the United Kingdom, Australia, and 
Denmark, and more latterly Austria, the Netherlands, Germany, New Zealand, and Ireland has been the implementation (to varying degrees) of a neoliberal agenda of deregulation, privatization, and tax cuts. As a result, the stock of government durable fixed capital has declined quite a lot, and in some cases markedly since the 1980s or 1990s. With the exception of the two nations with the highest ratio of public capital (New Zealand and Ireland), the

\section{Table 3.6 Real government gross fixed capital formation as percent of GDP, various OECD nations, 1960-2000}

\begin{tabular}{|c|c|c|c|c|c|c|}
\hline & 1960 & 1970 & 1980 & 1990 & 2000 & $\begin{array}{l}\text { Elasticity of output vis-à-vis public } \\
\text { capital 1960-2000 }\end{array}$ \\
\hline Australia & 52.2 & 50.1 & 53.8 & 46.5 & 40.0 & $0.65^{\mathrm{a}}$ \\
\hline Austria $^{\mathrm{b}}$ & 68.0 & 67.7 & 75.4 & 69.3 & 57.0 & $0.63^{\mathrm{a}}$ \\
\hline Ireland & 62.4 & 72.2 & 75.9 & 66.8 & 35.2 & -0.07 \\
\hline $\begin{array}{l}\text { The United } \\
\text { Kingdom }\end{array}$ & 51.1 & 60.0 & 63.9 & 48.5 & 40.3 & $0.40^{\mathrm{a}}$ \\
\hline The United States & 74.1 & 70.1 & 59.9 & 54.1 & 50.0 & $0.79^{\mathrm{a}}$ \\
\hline Germany & 48.2 & 52.7 & 58.4 & 52.0 & 47.1 & $0.88^{\mathrm{a}}$ \\
\hline New Zealand & 80.7 & 79.6 & 110.3 & 102.4 & 76.6 & 0.09 \\
\hline The Netherlands & 80.0 & 79.6 & 80.2 & 68.9 & 56.4 & $0.90^{\mathrm{a}}$ \\
\hline Denmark & 69.1 & 70.7 & 76.4 & 60.8 & 45.9 & $1.27^{\mathrm{a}}$ \\
\hline
\end{tabular}

Source: Adapted from Kamps (2004:21-31).

Notes

a Statistically significant at the 5 percent level.

b 1965-2000.

productivity (elasticity) of such capital on output was quite high, especially for the United States, Denmark, the Netherlands, Germany, Australia, and Austria. In most cases, the rationale for decreasing public capital was not backed up by supportive evidence.

These and a host of similar studies show that many kinds of government spending increase public capital. They raise serious concerns about the neoliberal project. The 1970s rhetoric about the crowding out impact of government spending seems to apply only to the low-impact spending priorities typical of a neoliberal pro $\urcorner$ gram. Overall, the results are fairly clear: if governments are to provide a social structure for accumulation they need to have a solid agenda for building public capital. In addition, deficit spending is usually required to achieve this end — to pro $\neg$ vide an autonomous source of demand and thereby ensure there is a net expansion of aggregate income.

Monetary policy under conservative rule also seems to have major limits. Since the late 1970s, central bank open market operations have been the main regulator of economic activity in most nations of the world. Central banks change official interest 
rates by modifying the level of reserves available to banks, consumers, and business. Many monetary transmission mechanisms affect economic activity (Iturriaga and Lopez 2000). Interest rates affect consumption and investment directly through changes in the cost of borrowing. More indirect mechanisms include the credit channel, where changes in the level of reserves affect the amount of bank lending, or impact the balance sheet of business firms. Two asset price mechanisms have become especially important during the neoliberalism age. The first is the exchange rate channel, where changes in interest rates impact on the value of the domestic currency, and therefore foreign demand for domestic goods and services. The second is the equity price channel, where changes in interest rates affect the demand for equity.

The equity channel is of special significance for nations following the lead of the (neoliberal) United States in emphasizing the equity source of corporate finance more than a credit or bank-based system. Even formerly bank-based systems in Europe, such as France, are moving in the equity direction, while the United Kingdom has long followed the equity route. Evidence indicates, however, that the equity-based system of corporate finance and placing more emphasis on the equity channel of monetary policy increases instability and risk in the economy (Arestis et al. 2001). One reason for this is the inability of interest rate changes to moderate speculative bubbles during business cycle upswings, as bank equity returns are ten times more sensitive to decreases than increases in official interest rates (Madura and Schnusemberg 2000:435). As Mishkin (2001:1) said: "targeting asset prices by central banks is likely to lead to worse economic outcomes and might even erode the support for their independence.”

This has led to three main developments, according to Binswanger (1999). First, there has been a marked drop in the link between money/credit and inflation during the 1980s and 1990s. Much of the credit created has been used for buying equities, and therefore credit expansion has propelled higher equity prices more than higher prices for investment or consumer goods. This has had an apparently positive effect on the economy by dampening inflationary forces. Second, reducing inflationary pressures, and limiting interest rate increases, has led to greater demand for equities, causing speculative bubbles in the economy. Bubbles exist when share prices do not reflect fundamental variables such as long-term dividends or productivity. These bubbles are not sustainable because fundamental variables condition stock prices in the long term. The use of derivates such as options, swaps, and futures has reduced the cost of diversification and leverage, and also increased the relative return for equity relative to industry.

This leads to the critical third point about neoliberalism. The changing structure and dynamics of the US financial system since the 1970s has increased the conflict between finance and industry, as the real sector has become a sideshow to the main game of capital gains in the equity market. This has had a negative impact on industry and longterm economic growth because it draws funds into equity markets rather than promoting innovation, workmanship, and sustainable investment in industry. Thus, during the long wave upswing, "economists had no trouble in explaining the [1949-1965] persistent bull market by standard valuation models according to which stock prices are determined by market fundamentals. But the [recent, 1984-1995] period is more troublesome” as stock returns have no relationship to fundamentals (Binswanger 2000:380). ${ }^{10}$

Broadly speaking, there was a reasonable link between stock prices and production during the long wave upswing of the 1950s and 1960s. But during the downswing of the 
1980s, 1990s, and 2000s stock prices became relatively autonomous from the industrial sector. This autonomy is most likely due to speculative bubbles during the 1980s-2000s. Linking monetary policy to confidence levels in the stock market contributed to the current crisis of confidence in corporate America and elsewhere, where finance is able to dominate industry, leading to financial crises and corporate fraud.

\section{Conclusion}

This chapter has examined the current neoliberal system of governance, which dominated the world during the mid-to-late 1970s through to the 2000s. If it constitutes a new, viable SSA it should provide the foundation for a long wave upswing in national economies. First, we situated the rise of neoliberalism within the framework of tendencies since the 1970s for governments of the world to promote privatization, deregulation, the reestablishment of US hegemony, and a development philosophy of stimulating private initiative. Then we explored the extent to which the recent long wave downswing has been reversed through neoliberal policies. During the neoliberal era, GDP and productivity growth declined, financial crises were more frequent and intense, and income inequality worsened in both the center and periphery.

Finally, we surveyed the extent to which fiscal and monetary policy have become more effective under neoliberal governments. The conclusions were not good for neoliberalism. Neoliberal policies have increased the crowding out of private investment through a relative decline in public capital in favor of transfer payments and military spending. Most of the decline in GDP could be explained by this shift from capital to current expenditures. Hence fiscal policy needs to be refocused, emphasizing public programs of education, infrastructure, transport, and communications, and expanding deficits to promote a sufficient supply of reserves in the hands of the private sector.

Monetary policy has also taken a turn for the worse. Greater emphasis on shareholder value has led to a decline in workmanship and industry, and contributed to speculative bubbles and financial crises. Trying to manipulate monetary policy on the back of an overvalued stock market leads to all sorts of problems, especially greater instability, more risk-taking, and greater fraud as profitability falters. Hence, current trends in both fiscal and monetary policy are unable to provide a foundation for the creation of a viable state social structure underlying accumulation. Major changes in governance are therefore required to improve long-term economic performance.

Overall, neoliberalism has not been a viable system of governance due to the greater instabilities, uncertainties, and unproductive nature of the practices. These have generated long-term lack of demand and excess supply and thus failed to propel private demand and productivity. As James Crotty (2000:368) says, since "The structures and practices of global Neoliberalism cannot create an economic... environment conducive to prosperity and security for the majority of the people in the developed and developing world," we need "new progressive structures and practices for national economies and for global integration.” A post-neoliberal governance program is detailed in Chapter 10. 
Notes

1 Others have sought to include other aspects of culture, such as race or ethnicity, into the SSA approach. One particularly good example of this is the work of Randy Albelda and Chris Tilly (1994).

2 Samuel Rosenberg (2003) pays particular attention to the role of the state in the postwar US experience. As he says about Keynesian policies:

During the 1940s and 1950s, Keynesian demand management policies were not systematically applied toward economic stimulation. Nevertheless, growing federal expenditures on goods and services helped to maintain aggregate demand and economic growth. Military expenditures were an important part of such spending, reflecting changes in overseas military activity, did destabilize the economy at times.

(Rosenberg 2003:63)

\section{He then goes on to say that}

A conservative form of Keynesianism dominated macroeconomic policymaking in the 1960s. Government policymakers believed that if aggregative macroeconomic policy tools were suitably utilized the economy would be able to grow steadily with low rates of inflation and low rates of unemployment. However, by the early 1970s, this view was demonstrated to be overly optimistic.

3 The question of the global operations of capitalism was a dominant theme in the social sciences in the late twentieth century. A critical issue of debate has been how the role of government has changed in the global Economy. Some believe that recent changes have little affect on the operation of (at least some) national governments (Helliwell 2000), while others claim that they have affected some critical state functions (Crotty et al. 1998), perhaps great enough to create a "race to the bottom" as states compete for transnational corporate investment (Tonelson 2000). For an analysis of the debate on how globalization impacts state effectiveness see O’Hara (2004b).

4 Many scholars have sought to examine what name to call the potential emerging institutional fabric or new long wave upswing. For instance, Terrence McDonough (2003) prefers to call the "emerging institutional framework" that of "global neoliberalism." While this may be a good term for what exists at present, it may well be the case that neoliberalism is coming to be challenged, not just in theory but also in governance practices. Chapter 10, examines this issue and whether a post-neoliberal form of governance is emerging, and more importantly, what policy framework such a trend might have to offer.

5 The literature on neoliberalism is vast. Some of the best relating neoliberalism to SSA analysis include David Kotz (2003) and Martin Wolfson (2003).

6 Attempts to reduce state spending may not be terribly effective (see Bougrine 2000: ch. 2). Although neoliberalism seeks to reduce the size of government, certain critical state expenses and lower Economic growth tend to maintain or increase such spending during 
long wave downswing. Neoliberalism may thus only lead to changes in the composition of state spending - from productive to less productive activities.

7 Conservative and radical economists had different responses to the perceived increase in the power of labor over capital. Conservative or neoliberal economists wanted to reduce the power of labor, while radicals saw an opportunity to develop an alternative Economic policy based on democratic governance programs. For instance, Bowles et al. (1990:233) proposed policies to reduce corporate waste, expand community knowledge and skills, and promote human rights and democratic participation through the Economy. As they say: "We are committed to an Economic that would offer sustainable improvements in living standards, strong democracy and community at home and global cooperation abroad, and more extensive Economic fairness."

8 These results stem from the main contradiction of neoliberalism-its inability to sustain aggregate demand due to their policy emphasis on supply. Indeed, neoliberal perspectives eschew demand as having no (or little) influence on long-run output.

9 In some nations, such as the United States, productivity rose sharply in the late 1990s. But the available evidence indicates that this was due to the cyclical upswing, or generally shortterm factors. Gordon (2001) argues that long-term sustainable high levels of productivity growth are unlikely due to the high tech and computer "revolution" because most of the advances have already taken place, and because computers are a pale imitation of the major technological advances of the past, such as railways, automobiles, and steel (at least as far as productivity is concerned). Freeman (2001) paints a similarly dim picture. Even those who are quite optimistic about the computer sector are skeptical about its productivity benefits (Jorgenson and Stiroh 2000).

10 Binswanger tested for Granger causality between stock returns production growth. He found a temporal link between the two variables leading from stock prices to production for the 1953-1965 period, but not for the 1984-1995 period. The probability that there was Number link was very low during 1953-1965 and high during 1984-1995. This led him to conclude that since the mid 1980s "stock returns do not seem to contain significant information about future real activity as before” (Binswanger 2000:386). (For more on this see Chapter 8.)

\section{References}

Albelda, Randy and Chris Tilly. (1994) “Towards a Broader Vision: Race, Gender and Labor Market Segmentation in the Social Structure of Accumulation Framework,” in David Kotz, Terrence McDonough, and Michael Reich (eds), Social Structures of Accumulation: The Political Economy of Growth And Crisis, Cambridge: Cambridge University Press, pp. 212230.

Arestis, Philip, P.Demetriades, and K.Luintel. (2001) "Financial Development and Economic Growth: The Role of Stock Markets,” Journal of Money, Credit, and Banking, Volume 33, Number 1, pp. 16-41.

Binswanger, Mathias. (1999) Stock Markets, Speculative Bubbles and Economic Growth: New Dimensions in the Co-evolution of Real and Financial Markets, Cheltenham, UK and Northampton, MA: Edward Elgar.

Binswanger, Mathias. (2000) "Stock Returns and Real Activity: Is There Still a Connection?," Applied Financial Economic, Volume 10, pp. 379-387.

Bleaney, Michael. (1985) The Rise and Fall of Keynesian Economic: An Investigation of its Contribution to Capitalist Development, London: Macmillan.

Bloch, Harry and H.K.Sam Tang. (2004) "Recent Performance of the Developing East Asian Economics,” in Phillip Anthony O'Hara (ed.), Global Political Economy and the Wealth of Nations: Performance, Institutions, Problems and Policies, London and New York: Routledge. 
Bourgrine, Hassan. (2000) The Economics of Public Spending: Debts, Deficits and Economic Performance, Cheltenham, UK and Northampton, MA: Edward Elgar.

Bowles, Sam, David Gordon, and Thomas Weisskopf. (1990) After the Wasteland: a Democratic Economic for the Year 2000, Armonk, NY and London: M.E. Sharpe.

Crotty, James. (2000) "Structural Contradictions of the Global Neoliberal Regime," Review of Radical Political Economic, Volume 32, Number 3, pp. 361-368.

Crotty, James, Gerard Epstein, and P.Kelly. (1998) "Multinational Corporations in the Neo-Liberal Regime,” in D.Baker, Gerard Epstein, and Robert Pollin (eds), Globalization and Progressive Economic Policy, Cambridge and New York: Cambridge University Press, pp. 117-143.

Deininger, K. and L.Squire. (2003) Measuring Income Inequality: A New Database, Washington, DC: World Bank, http://www.worldbank.org/research.growth/dddeisqu.htm

Dutt, Amitava Krishna. (2004) "Uneven Development, Convergence and Numberrth-South Interaction,” in P.A.O’Hara (ed.), Global Political Economy and the Wealth of Nations. London and New York: Routledge.

Eichengreen, Barry and D.Bordo Michael. (2002) Crises Numberw and Then: What Lessons from the Last Era of Financial Globalization?, National Bureau of Economic Research, Working Paper 8716. http://www.nber.org/papers/w8716.

EU (European Union) The EU's Relations with Brazil, http://europa.eu.int/comm/\%20external_relations/brazil/intro/ (accessed 2 December 2004).

Freeman, Chris. (2001) “A Hard Landing for the 'New Economy'? Information TechNumberlogy and the United States National System of InNumbervation," Structural Change and Economic Dynamics, Volume 12, pp. 115-139.

Galbraith, James K. (2003) Manufacturing Wage Inequality in Mexico and China. LBJ School of Public Affairs, University of Texas, Austin, February 3.

Galbraith, James K. and Hyunsub Kum. (2003) Estimating the Inequality of Household Incomes: Filling Gaps and Correcting Errors in Deininger \& Squire, UTIP Working Paper Number 22, LBJ School of Public Affairs, University of Texas, Austin, February 3.

Gordon, David M. (1980) "Stages of Accumulation and Long Economic Cycles," in Terrence K.Hopkins and Immanual Wallerstein (eds), Processes of the World System, New York: Sage Publications, pp. 9-45. Reprinted in David M.Gordon, Economic and Social Justice: Essays on Power, Labor and Institutional Change, edited by Samuel Bowles and Thomas E, Weisskopf, Cheltenham, UK and Northampton, MA: Edward Elgar, pp. 93-129.

Gordon, Robert J. (2001) 'Does the 'New Economy' Measure up to the Great Inventions of the Past?,” Journal of Economic Perspectives, Volume 14, Number 4, pp. 49-74.

Helliwell, John F. (2000) "Balanced Growth: The Scope for National Policies in a Global Economy,” in M.Richardson (ed.), Globalisation and International Trade Liberalisation: Continuity and Change. Cheltenham, UK and Northampton, MA: Edward Elgar, pp. 46-62.

Herrero, Alicia Garcia and Pedro del Rio. (2003) Financial Stability and the Design of Monetary Policy. Servicio De Estudios, Documento de Trabajo Number 0315, Madrid: Bank of Spain Working Paper.

Ibrahim, M. (2001) “The Effects of Government Spending on Private Capital Formation: The Case of Malaysia,” International Economic, Volume 54, Number 2, pp. 187-201.

IMF (International Monetary Fund). (2002) “Statistical Appendix,” World Economic Outlook, September, pp. 153-160.

Iturriago, F. and J.Lopez, (2000) "More on the Credit Channel of Monetary Policy Transmission: an International Comparison,” Applied Financial Economic, Volume 10, pp. 423-434.

Jorgenson, Dale W. and K.J.Stiroh. (2000) "Raising the Speed Limit: U.S. Economic Growth in the Information Age,” Brookings Papers on Economic Activity, Number 1, pp. 125-235.

Kamps, Christophe. (2004) New Estimates of Government Net Capital Stocks for 22 OECD Countries 1960-2001, IMF Working Paper. Washington, DC: IMF.

King, W. (2003) The Functional Distribution, Again, http://williamking.www.drexel.edu/\%20top/prin/txt/factors/dist7.html 
Kotz, David M. (2003) "Neoliberalism and the Social Structure of Accumulation Theory of LongRun Capital Accumulation”, Review of Radical Political Economic, Volume 35, September, pp. 263-270.

Laopodis, N. (2001) "Effects of Government Spending on Private Investment," Applied Economic, Volume 33, pp. 1563-1577.

Little, J.S. and G.P.Olivei. (1999) "Why the Interest in Reforming the International Monetary System,” New England Economic Review, Number 3 (September/October), pp. 53-84.

McDonough, Terrence. (2003) "What Does Long Wave Theory Have to Contribute to the Debate on Globalization?” Review of Radical Political Economics, Volume 35, Number 3, Summer, pp. 280-286.

Maddison, Angus. (2000) The World Economy: A Millennial Perspective, Paris: OECD.

Madura, J. and O.Schnusenberg. (2000) "Effects of Federal Reserve Policies on Bank Equity Returns,” Journal of Financial Research, Volume 23, Number 4, pp. 421-447.

Miller, N. and C.Tsoukis (2001) "On the Optimality of Public Capital for Long-Term Economic Growth: Evidence from Panel Data,” Applied Economic, Volume 33, pp. 1117-1129.

Mishkin, Frederick. (2001) The Transmission Mechanism and the Role of Asset Prices in Monetary Policy, NBER Working Paper Number 8617.

OECD. (2002) Benefits and Wages-OECD Indicators. Paris: OECD.

O’Hara, Phillip Anthony. (1995) "Household Labor, the Family, and MacroEconomic Instability in the United States: 1940s-1990s," Review of Social Economy, Volume 52, Number 1, pp. 89120.

O’Hara, Phillip Anthony. (2000) Marx, Veblen and Contemporary Institutional Political Economy: Principles and Unstable Dynamics of Capitalism, Cheltenham, UK and Northampton, MA: Edward Elgar.

O’Hara, Phillip Anthony. (2004a) "A New Family-Community Social Structure of Accumulation for Long Wave Upswing in the United States?,” Forum for Social Economics, Volume 34, Number 2, Spring, pp. 51-80.

O’Hara, Phillip Anthony, (ed.) (2004b) Global Political Economy and the Wealth of Nations: Performance, Institutions, Problems and Policy, London and New York: Routledge.

Pressman, Steven. (2002) "Explaining the Gender Poverty Gap in Developed and Transitional Economics,” Journal of Economic Issues, Volume 36, Number 1, pp. 17-40.

Rosenberg, Samuel. (2003) American Economic Development Since 1945, New York: Palgrave Macmillan.

Smeeding, Timothy M. (2001) The Gap between the Rich and the Poor: A Cross-National Perspective for Why Inequality Matters and What Policy Can Do to Alleviate It, Tokyo: National Institute of Population and Social Security Research.

Stiglitz, Joseph. (1999) “Quis Custodiet Ipsos Custodes?,” Challenge, Volume 42, Number 6, pp. 26-67.

Tonelson, A. (2000) The Race to the Bottom: Why a Worldwide Worker Surplus and Uncontrolled Free Trade are Sinking American Living Standards, Boulder, CO and Oxford: Westview Press.

UNDP (United Nations Development Program). (2004) Human Development Report 2004, New York: UNDP.

Visano Spotton, Brenda. (2004) "Global Financial Instability, Speculative Bubbles and Financial Crashes,” in P.A.O’Hara (ed.), Global Political Economy and the Wealth of Nations:

Performance, Institutions, Problems and Policies, London and New York: Routledge.

Weber, Christian E. (2000) "Government Purchases, Government Transfers, and the Post-1970

Slowdown in U.S. Economic Growth,” Contemporary Economic Policy, Volume 18, Number 1, pp. 107-123.

Wolfson, Martin H. (1994) “The Financial System and the Social Structure of Accumulation ,” in D.M.Kotz, T.McDonough, and M.Reich (eds), Social Structures of Accumulation: The Political Economy of Growth and Crisis, Cambridge: Cambridge University Press. 
Wolfson, Martin H. (2003) "Neoliberalism and the Social Structure of Accumulation," Review of Radical Political Economic, Volume 35, Number 3, pp. 255-262.

Wolfson, Murray H. (1994) “The Financial System and the Social Structures of Accumulation,” in D.M.Kotz, T.McDonough, and M.Reich (eds), Social Structures of Accumulation: The Political Economy of Growth and Crisis, Cambridge, UK and New York: Cambridge University Press, pp. 133-146.

World Bank. (2003) WDI Online: GDP Per Capita (Constant Prices), Washington, DC: World Bank. http://www.publications.worldbank.org/subscriptions/WDI/ (accessed September 5, 2004).

\section{Further reading}

ABS (Australian Bureau of Statistics). (2003) 6523.0 Income Distribution, Australia, Canberra: ABS.

Aglietta, Michel. (2001) The International Monetary Fund and the International Financial Architecture, Centres d'Etudes Perspectives et d'Informations Internationales (CEPII) Working paper.

Arrighi, Giovanni. (1994) The Long Twentieth Century: Money, Power and the Origins of Our Times, London and New York: Verso.

Brenner, Robert. (1998) “The Economic of Global Turbulence,” New Left Review, Number 229, pp. $1-265$.

Carlson, M. and L.Hernandez, (2002) Determinants and Repercussions of the Composition of Capital Flows, IMF Working Paper 02/86.

Kregel, Jan A. (1999) "Was There an Alternative to the Brazilian Crisis?” Revista de Economia Politica, Volume 19, Number 3, pp. 23-38.

Lindert, P.H. and J.G.Williamson. (2001) Does Globalization Make the World More Unequal?, National Bureau of Economic Research Working Paper. Washington, DC: NBER.

Lippit, Victor D. (1997) "The Reconstruction of a Social Structure of Accumulation in the United States,” Review of Radical Political Economic, Volume 29, Number 3, pp. 11-21.

Maddison, Angus. (1991) Dynamic Forces in Capitalist Development: A Long-Run Comparative View, Oxford and New York: Oxford University Press.

Milanovic, Branko. (1998) Explaining the Growth in Inequality During the Transition, Washington, DC: World Bank, Working Paper.

Moseley, Fred. (1997) “The Rate of Profit and the Future of Capitalism,” Review of Radical Political Economic, Volume 29, Number 4, pp. 23-41.

O'Hara, Phillip Anthony. (2000) "The Evolution of a New 'Neoliberal, Balanced Budget' Social Structure of Accumulation? Emerging Prospects for the United States and World Economics," in H.Bougrine (ed.), The Economic of Public Spending: Debts, Deficits and Economic Performance, Cheltenham, UK and Northampton, MA: Edward Elgar, pp. 30-56.

O’Hara, Phillip Anthony. (2003a) “Deep Recession and Financial Instability or a New Long Wave of Economic Growth for U.S. Capitalism? A Regulation School Approach,” Review of Radical Political Economic, Volume 35, Number 1, pp. 18-43.

O’Hara, Phillip Anthony. (2003b) "Recent Changes to the IMF, WTO and SPD: Emerging Global Mode of Regulation or Social Structure of Accumulation for Long Wave Upswing?” Review of International Political Economy, Volume 10, Number 2, pp. 485-518.

Poirot, C.S. (2001) "Financial Integration Under Conditions of Chaotic Hysteresis," Journal of Post Keynesian Economic, Volume 23, pp. 485-508.

Van Wincoop, Eric and K.-M.Yi. (2000) "Asia Crisis Postmortem: Where Did the Money Go and Did the United States Benefit?,” Economic Policy Review (Federal Reserve Bank of New York), September, pp. 51-68. 
Wallerstein, Immanuel. (1991) "The Three Instances of Hegemony in the History of the Capitalist World-Economy,” in G.T.Crane and A.Amawi (eds), The Theoretical Evolution of International Political Economy, New York and Oxford: Oxford University Press.

Wray, L.Randall. (1998) Understanding Money: The Key to Full Employment and Price Stability, Aldershot, UK and Northampton, MA: Edward Elgar.

Yaghmaian, Behzad. (1998) "Globalization and the State: The Political Economy of Global Accumulation and Its Emerging Mode of Regulation,” Science and Society, Volume 62, Number 2, pp. 241-265. 


\section{4 \\ A transnational corporate social structure of accumulation?}

\section{Introduction}

According to leading social structure of accumulation (SSA) scholars, the corporation is a critical institution in the accumulation and growth process. ${ }^{1}$ As the late David Gordon said, for instance, when examining the SSA role of agents and motors of accumulation: "A relatively stable internal corporate structure is...necessary in order to permit capitalist decision-making [And s]ome moderation of competition is necessary to prevent the kind of economic instability which would undermine accumulation” (Gordon 1980:13). ${ }^{2}$

SSA scholars have tended to examine the question of social structures of accumulation from a national perspective, whereas French regulation analysts have generally tried to keep a global view. This chapter seeks to follow regulation scholars in this respect as we examine the second chapter on the Global System of Power and Accumulation: transnational corporations. During the postwar golden age of the 1950s and 1960s, Fordism was the leading system of production-distribution-exchange in the world. Part of this Fordist structure was the dual corporate system of giant, oligopoly corporations in the leading sectors, and the competitive firms that had a derivative relationship to the leading corporations. The oligopoly firms were the technological leaders in the motor vehicle, energy, heavy industry, and consumer durable sectors. This partial monopoly position enabled them to have high profits and to reinvest much of this economic surplus into research and development (R\&D) activities that reinforced their top position. The competitive sector had a largely dependency relationship to the leading corporations as suppliers, outsourcers, and contractors, supplying moderately important but essentially subsidiary activities when compared to the dominant players.

Over time, however, the dual system of oligopoly-competitive firms broke down somewhat as the dominant firms began to change and some lost their edge to other nations, industries, and firms. The old technology industries began to slow down as the product cycle of the postwar boom came to an end and new systems of demand were required to propel growth and accumulation. New players emerged from Asia to compete with the old high-wage sectors in the West. High technology sectors emerged in the computing, telecommunications, biotechnology, and media sectors that made redundant many of the techniques and products of the old sectors. The new firms that arose depended upon continual innovation, competition, and adjustment rather than establishment methods and products. During the 1980s, 1990s, and 2000s these new areas, sectors, and firms came to dominate the industrial landscape at the expense of the old areas, sectors, and firms that had to adjust or go into decline. 
However, it is by no means obvious that the new transnational corporate (TNC) system has satisfactorily resolved age-old problems of profitability and accumulation. Many argue that the existing system has numerous contradictions that inhibit corporate and economy-wide performance. For instance, competition may be too great leading to declining margins and investment. High-tech industries may propel speculative bubbles that inhibit long-term sustainable growth and accumulation. There may be insufficient aggregate demand as supply-side strategies take priority in the age of neoliberalism, downsizing, and innovation. The opening up of new markets in Asia may be insufficient in the light of the performance of advanced capitalist nations, Eastern Europe, SubSaharan Africa, and Latin America. Overall, the contemporary corporate system may be too contradictory to propel sufficient accumulation and growth as profitability fails to materialize in the long term.

This chapter explores in some detail whether the new TNC arrangements are able to promote sufficient global profitability, accumulation, and growth into the new millennium. The first major section deals with the issue of the structure and dynamics of the new system of corporate organization and development. In the second main section the ability of this new structure to solve the global problems of productivity, profit, and growth are scrutinized. Then in the last major section, the degree to which global market expansion and foreign direct investment (FDI) are able to propel profitability and accumulation are examined vis-à-vis the major continents of the world. A conclusion follows.

\section{The new transnational corporate system}

A business corporation is defined as a legal and organizational entity that has a potential life beyond that of its current owners, containing certain internal structures that are outside direct market relations, and concerned primarily with profitability and growth or at least satisficing. A TNC is one that owns and controls companies or assets in more than one nation. As UNCTAD (2002a:14) points out, there are around 65,000 TNCs affiliated to 850,000 firms abroad, with a combined TNC value added of US\$3.5 trillion, FDI of US\$7 trillion, and total sales of US\$18.5 trillion. While during the golden age of the 1950s and 1960s TNCs expanded considerably, it could be argued that it has only really been since the 1980s that TNCs have begun to dominate the increasingly global scene through FDI flows. Indeed, the second era of globalization (the first was during the 1880s-1914) started in earnest during the 1980s and has been reinforced by the operations of TNCs worldwide since then.

Four main tendencies and three dominant engines of growth have been conspicuous over the past few decades in the global corporate economy. The first tendency of the new corporate form is an environment of increasing globalization in which trade barriers have been reduced substantially, controls on foreign investment were dismantled, and exchange rates became much more flexible throughout the world. ${ }^{3}$ These trends have been critical to the growth of TNCs, so that they could be more flexible in the way they function, establish subsidiaries in many nations, move their operations to other nations, or operate via contractual arrangements and patents. This flexibility is important also in the sense of being able to develop vertical, horizontal, conglomerate, and diversified forms of 
organization. Part and parcel of this trend is the requirement that wages and conditions be organized on a relatively deregulated basis, and that temporary or permanent residency regulations are adaptable to the business environment. Through these trends toward flexibility and deregulation of the economic and financial climate, TNCs are supposedly better able to contribute to global growth and development.

The second tendency of this new TNC environment concerns the structure of norms and processes associated with competition and innovation. The old dual corporate system of the golden age was based on oligopoly firms reaping a large surplus that was then put into research and development activities, advertising, and other means of extracting economic rents. But with the maturation of this technology and the evolution of sectors and practices, a new form has emerged. This form is essentially Schumpeterian in nature and relates to a complex dialectic of innovation-competition-innovation ad infinitum. The leading sectors of the new system are the high technology industries of biotechnology, information, telecommunications, and computers. A firm or series of firms develop new methods or practices that are successful if the development-production-marketing phases are effective. If effective, profits are enhanced since the first movers are ahead of the others. Over time, other firms tend to move into the sector to produce a similar or superior product. This leads to profits moving from the old firms to new ones, and perhaps to new leaders in the field.

The process of innovation-competition-innovation has speeded up in recent decades, and so long as this complex process continues through several runs and markets emerge, growth and accumulation can be enhanced sufficiently to provide adequate profitability for long wave upswing. There is a drop in the average "surplus capacity" of firms as they seek to reduce overheads, unnecessary labor costs, warehousing, and unprofitable lines of activity. Firms must in general be quicker to switch production lines, areas, and markets. They must also be quicker to engage in acquisitions and mergers if this can establish required profitability and reduce competition. ${ }^{4}$

The third tendency is for TNCs to move into areas of high growth and away from old production centers and markets. The new corporate system is one where corporations are relatively "foot loose" and able to choose where they produce, export, advertise, and plan their activities. Currently, corporations are moving into areas where market growth is strong, such as East and South-East Asia (primarily), followed by certain special industrial zones (such as Mexico, Costa Rica, and Ireland), followed by some emerging and transitional economies of Central and Eastern Europe (such as Hungary, the Czech Republic, and Poland). This new pattern of uneven growth and development is leading to some nations developing a viable corporate system of production, distribution, and exchange for the first time. But it is also establishing a pattern where much of the world is becoming less important or neutral in growth patterns. For instance, Western nations and Japan are falling behind, especially in terms of growth and productivity, mainly at the expense of Asian nations. But more critical is the fact that most of Latin America is not growing in relative strength, and Africa is falling behind most other areas. So the only real plus is that some nations of Asia, special centers, and a few transitional countries are starting to benefit; but it is not a global system of growth and accumulation.

The fourth tendency of the new corporate system is the establishment of certain institutional or organizational innovations within and between the TNCs. These include the promotion of global commodity chains, value added chains, and diversified practices 
and activities. Global commodity chains are ways of organizing inputs in various areas so as to produce a viable product (or series of products) that enhance market share. Producer and buyer-driven commodity chains are common, but buyer-driven chains are becoming more dominant, especially in the fashion and laptop computing industries. ${ }^{5}$ The production of laptop computers is often done by producing simple inputs such as cables and keys in low skills areas such as the Philippines and Indonesia, complex products such as screens and computer chips in high skill areas such as Singapore and South Korea, relying on some highly efficient transport companies or subsidiaries, and then marketing and selling the product in high value-added markets such as Japan, the United States, and Europe, with the help of sophisticated media groups for advertising and promotion. This triangular system of production, distribution, and exchange is both a way of reducing costs, specializing according to comparative advantage, and reducing bottlenecks through alternative sites and practices (see Dicken 2003).

\section{Global performance and engines of growth}

In the light of these four main tendencies, the question arises as to how these TNCs have performed over the past few decades, and whether their performance has improved of late so as to promote system profitability, investment, growth, and development. We start first with the engines of growth and accumulation, those characteristics of the transnational system that enhance corporate and market expansion. Three such engines of growth have been FDI, cross-border mergers and acquisitions (M\&As), and high-tech manufactured exports.

The first engine of global growth is FDI inflows, which grew from US\$59 billion in 1982 to US\$203 billion in 1990 and US\$735 billion in 2001, or 24 percent (1986-1990), 20 percent (1991-1995), and 40 percent (1996-2000) average annual growth over the last two decades. FDI is distinguished from portfolio and bank-loan types of linkages with a domestic corporation and refers to the extent to which there is foreign investment in organizations where the parent company has management rights and control (Cohn 2000:274). More specifically it can be defined as:

an investment involving a long-term relationship and reflecting a lasting interest and control of a resident entity in one economy in an enterprise resident in an economy of one country other than that of the foreign direct investor (foreign affiliate). An equity capital stake of 10 percent or more of the ordinary shares or voting power for an incorporated enterprise, or its equivalent for an unincorporated enterprise, is normally considered as a threshold for FDI. FDI flows comprise capital provided (either directly or through other related enterprises) by a foreign direct investor to a FDI enterprise, or capital received from an FDI enterprise by a foreign direct investor.

(UNCTAD 2003a)

The rapid expansion of FDI over the past couple of decades (aside from the sharp decline during the global downturn of the early 2000s) indicates a heightening of investment 
linked to property rights and operational power. Positive functions that FDI can perform include the sharing of knowledge, technology development, expansion of markets, and a more integrated regional or global systems of production, distribution, and exchange (see Lall 2002b). But FDI can have negative consequences if it is not productively used for the expansion of plant and equipment, if it is a substitute for domestic investment, and if the subsequent profits are repatriated overseas in large quantities (Backer and Sleuwaegen 2003).

The second engine of growth is in cross-border M\&As, which is included as FDI and expanded from US\$151 billion in 1990 to US\$601 billion in 2001. M\&As grew at an annual average rate of 26 percent (1986-1990), 23 percent (1991-1995), and 50 percent (1996-2000), growing very rapidly in the late 1990s (although declining during the global slowdown of the early 2000s). The expansion of the late 1990s indicates the possible advantages in taking over and merging with overseas entities rather than simply setting up a new company in a foreign land. The domestic company often has certain advantages such as local knowledge and business acumen. The links take the form of TNCs purchasing domestic assets through M\&As. Also significant in this respect are strategic alliances-increasingly in the services sector-which include joint ventures and informal associations (OECD 2001).

The third engine of growth is high-tech manufactures, the exports of which have grown from 9 percent (1982) to 15 percent (1990) to 23 percent (2000) of total manufactures exports globally (Lall 2002b:57). New technology is a critical part of the TNC engine, especially in the areas of biotechnology, electronics, and services. New technology has become a more important part of rent seeking behavior as competition has increased in the global economy and pure rents are harder to extract in the long term. Greater competition is part and parcel of the innovation dialectic, through the development of global commodity chains and value chains in the global arena.

These three engines of growth are inextricably related to the increasing transnationality of corporations from 51 percent in 1990 to 58 percent in 2000, as the proportion of foreign assets, sales, and employment have expanded relative to global GDP (gross domestic product) (UNCTAD 2002a:93). However, these engines predicate uneven growth and development, as various regional and local patterns and trends impact on the global system. Nations and regions have different patterns of economic, political, and social interaction, and these different patterns will impact on transnational activity, FDI, mergers, and technology exports. Also, there are regional differences in the degree of market segmentation, the size of the domestic market, and the existence of cultural and social barriers to global penetration. Circular and

Table 4.1 Unevenness in the global political economy, 1998-2000 average

\begin{tabular}{|c|c|c|c|c|c|c|c|c|}
\hline & World & $\begin{array}{l}\text { West } \\
\text { Europe }\end{array}$ & $\begin{array}{l}\text { North } \\
\text { America }\end{array}$ & $\begin{array}{l}\text { Asia } \\
\text { and } \\
\text { Pacific }\end{array}$ & $\begin{array}{l}\text { Latin } \\
\text { America }\end{array}$ & $\begin{array}{l}\text { Africa } \\
\text { (Sub- } \\
\text { Saharan) }\end{array}$ & $\begin{array}{l}\text { East and } \\
\text { Central } \\
\text { Europe }^{\mathrm{a}}\end{array}$ & $\begin{array}{l}\text { Middle } \\
\text { East and } \\
\text { North } \\
\text { Africa }\end{array}$ \\
\hline $\begin{array}{l}\text { FDI } \\
\text { inflow }\end{array}$ & 100 & 37.4 & 34.8 & 10.1 & 5.83 & 2.34 & 0.77 & 0.34 \\
\hline
\end{tabular}




$\begin{aligned} & \text { (share of } \\ & \text { world } \\ & \text { total) }\end{aligned}$
$\begin{aligned} & \text { Exports } \\ & \text { (share of }\end{aligned}$
$\begin{aligned} & \text { world } \\ & \text { tatal) }\end{aligned}$

Source: Adapted from UNCTAD (2002a: chs 3, 6).

Notes

a Russia, Hungary, Czech Republic. Poland, Romania, and Estonia.

b Includes the Caribbean.

c 2001.

d Estimate.

cumulative transnational activities tend to magnify these differences. All this results in the existence of regional engines of expansion vis-à-vis certain peripheral and semiperipheral areas. Table 4.1 gives an indication of these uneven tendencies at the global level.

This data reveals the existence of three main continental engines of global growth: Western Europe, the United States, and Asia. The big development is the relatively recent entry of certain nations of Asia into the club of growth and development. The decline of Japan has not yet been counteracted by the rise of China and other nations of East and South-East Asia. Certainly the nations of Latin America, Africa, the transitional economies of Central and Eastern Europe, and the Middle East play no really significant role in the global process. This inability to include more nations in the global process is a major limit on growth and accumulation.

Another limit on growth and accumulation is the unstable nature of most of the dynamic engines of transnational expansion, especially FDI and M\&As. This is shown in Table 4.2. For instance, there is an unstable tendency for global FDI growth to expand to great heights in the short business booms, such as the 1985-1990 and 1995-2000 periods, only to crash during the subsequent global recession, especially during 2001-2003 when it declined from US $\$ 1,402$ billion to US $\$ 570$ billion (average yearly decline of about 20 percent). A more extreme picture is seen for M\&As as the cycle boom of the late 1990s saw growth of just less than 200 percent per annum, with a decline during the early 2000s of just under 30 percent per annum. Luckily, FDI inflows as a percent of domestic investment in many nations is under 1 percent. But there is the threat of greater instability in the future; for instance, FDI/Investment ratios grew to over 2 percent by the time of the business cycle peak of 2000, only to crash to 0.77 percent in 2003. 
Table 4.2 Unstable FDI inflow, mergers and acquisitions, and FDI/investment

\begin{tabular}{|c|c|c|c|c|c|c|}
\hline & 1980 & 1985 & 1990 & 1995 & 2000 & 2003 \\
\hline FDI inflow (\$billions) & 65 & 67 & 223 & 353 & 1402 & 570 \\
\hline $\begin{array}{l}\text { FDI inflow (annual } \\
\text { average \% A) }\end{array}$ & n.a. & $\begin{array}{r}0.62 \\
(1980- \\
1985)\end{array}$ & $\begin{array}{r}46.50 \\
(1985- \\
1990)\end{array}$ & $\begin{array}{r}11.66 \\
(1990- \\
1995)\end{array}$ & $\begin{array}{r}59.43 \\
(1995- \\
2000)\end{array}$ & $\begin{array}{c}-19.78 \\
(2000- \\
2003)\end{array}$ \\
\hline $\begin{array}{l}\text { Value of M\&As (over } \\
\text { \$billion) }\end{array}$ & n.a. & $\begin{array}{r}30.00 \\
(1987)\end{array}$ & 60.90 & 80.94 & 866.20 & 141.10 \\
\hline $\begin{array}{l}\text { M\&As over \$billion } \\
\text { (annual average \% A) }\end{array}$ & n.a. & n.a. & $\begin{array}{r}34.33 \\
(1987- \\
1990)\end{array}$ & $\begin{array}{r}6.40 \\
(1990- \\
1995)\end{array}$ & $\begin{array}{r}195.47 \\
(1995- \\
2000)\end{array}$ & $\begin{array}{c}-27.90 \\
(2000- \\
2003)\end{array}$ \\
\hline $\begin{array}{l}\text { FDI inflows (\% } \\
\text { investment) }\end{array}$ & 0.026 & n.a. & 0.043 & 0.058 & 0.207 & 0.077 \\
\hline
\end{tabular}

Source: Adapted from UNCTAD (2004:3, 4, 6, 9).

These and other limits are likely to be inhibiting the emergence of long wave upswing in the global economy. We turn now to the evidence of global profit, investment, and growth in a long wave perspective.

\section{Transnational profitability, accumulation, and productivity}

We start with the rate of profit-more precisely, the after-tax profit divided by the value of tangible corporate assets (times 100). According to Dennis Mueller (1990), the rate of profit $\left(\pi_{\mathrm{it}}\right)$ is equal to the competitive rate of return $\left(\pi \mathrm{c}_{\mathrm{it}}\right)$ plus the permanent rent for specific firms $\left(\pi \mathrm{r}_{\mathrm{it}}\right)$ and a short-run rent $\left(\pi \mathrm{s}_{\mathrm{it}}\right)$ :

$$
\pi_{\mathrm{it}}=\pi \mathrm{c}_{\mathrm{it}}+\pi \mathrm{r}_{\mathrm{it}}+\pi \mathrm{s}_{\mathrm{it}}
$$

where the competitive rate of return ( $\pi$ cit) may be approximated by the yield on longterm government bonds ( $\mathrm{Yg}_{\mathrm{t}}$ ) (Kessides 1990). The rate of profit for the largest $500 \mathrm{US}$ TNCs is compared with the yield on 10-year US Treasury Bonds for the period 19542002 in Table 4.3. ${ }^{6}$

Here the rate of profit has consistently fallen since the 1960s, being high for the long wave upswing of the 1950s and 1960s, and successively lower for each decade of the downswing in the 1970s-2000s. Again, the recent experience is poor. The main thing that emerges from this table is that long wave upswing during the 1950s and 1960s consistently saw a positive above normal competitive rent for business in general, while during downswing this above normal competitive rent was consistently negative. The negative figures were due to the operation of two factors: deep recessions during the mid1970s, early 1980s, early 1990s, and early 2000s (which reduce profit rates) and 
stagflation during the late 1970s through to the early 1990s (which led to higher interest rates, usually with a lag). Long upswing was generally not subject to these forces.

Table 4.3 After-tax rate of profit of the largest 500

US (TN) Corporations, annual averages, decade by decade, 1954-2002*

\begin{tabular}{|c|c|c|c|c|c|}
\hline $\begin{array}{l}\text { Phase of } \\
\text { long wave }\end{array}$ & Year & $\begin{array}{l}\text { Raw profit } \\
\text { rate } \\
\text { figures }^{\mathrm{a}}\end{array}$ & $\begin{array}{l}\text { Profit rate } \\
\text { adjusted for } \\
\text { data revison }(\pi)\end{array}$ & $\begin{array}{l}\text { Yield on } 10 \\
\text { year-US } \\
\text { treasury bonds } \\
\text { (Yg) }\end{array}$ & $\begin{array}{l}\text { Above normal } \\
\text { competitive rents } \\
\pi-\mathrm{Yg}\end{array}$ \\
\hline Downswing & $\begin{array}{r}2000- \\
2002\end{array}$ & 1.32 & 3.30 & 5.22 & -1.92 \\
\hline Downswing & $\begin{array}{r}1990- \\
1999\end{array}$ & 2.29 & 4.02 & 6.66 & -2.64 \\
\hline Downswing & $\begin{array}{r}1980- \\
1989\end{array}$ & 5.30 & 5.30 & 10.60 & -5.30 \\
\hline Downswing & $\begin{array}{r}1970- \\
1979\end{array}$ & 6.30 & 6.30 & 7.49 & -1.19 \\
\hline Upswing & $\begin{array}{r}1960- \\
1969\end{array}$ & 7.15 & 7.15 & 5.11 & +2.04 \\
\hline Upswing & $\begin{array}{r}1954- \\
1959\end{array}$ & 7.71 & 7.71 & 3.01 & +4.70 \\
\hline
\end{tabular}

Source: Adapted from Fortune Magazine ${ }^{\mathrm{a}}$ (1955-2003); Federal Reserve System ${ }^{\mathrm{b}}$ (2000, 2003, 2004).

Note

* This table shows profits after taxes, after extraordinary credits, and after cumulative effects of accounting changes, divided by corporate assets.

\section{Table 4.4 Rate of profit for 500 largest global corporations, 1988-2002}

\begin{tabular}{lrrrrrrrr}
\hline & 1988 & 1989 & 1990 & 1991 & 1992 & 1993 & 1994 & \\
\hline Profit rate & 3.8 & 4.4 & 3.4 & 2.3 & 0.8 & 1.9 & 2.3 & \\
& 1995 & 1996 & 1997 & 1998 & 1999 & 2000 & 2001 & 2002 \\
\hline Profit rate & 2.5 & 3.0 & 3.3 & 2.8 & 3.1 & 3.6 & 1.6 & 0.6 \\
\hline
\end{tabular}

Source: Adapted from Fortune Magazine, 1989-2003. 1994-2002 data was adjusted in the same way as in Table 4.3.

What about the profit rate for the largest global TNCs? See Table 4.4. Here we follow the data on a yearly basis since the late 1980s (again adjusted for the data revision of 19942002). The evidence is very clear. The rate of profit for the largest global corporations has a similar trend for the 1990s as the profit rate for the largest US TNCs: it is very low. 
In fact, the profit rate for global firms is even worse than for domestic ones. Of course, this does not mean that every large TNC is experiencing low profitability, only that the average is very low. For instance, the profit rate for some of the better performing global corporations - sector by sector compared with the global average-is shown in Table 4.5.

A number of things are clear from this data. First, the Pharmaceuticals sector is the clear leader in terms of the rate of profit. Evidence points to the relatively high rate of innovation linked to the high barriers to entry due to the high level of R\&D and expertise necessary in this area. Second, the new technology computing and electronics sectors have performed relatively poorly, with telecommunications having somewhat above average net returns, and computers and electronics

Table 4.5 Rate of profit for better performing sectors: global 500 largest firms, 1990-2002 (annual average rate)

\begin{tabular}{|c|c|c|c|}
\hline Sector & Profit rate & Sector & Profit rate \\
\hline Global median (adjusted) & 3.3 & Publishing/printing & 3.18 \\
\hline Pharmaceuticals & 12.8 & Computers, office equipment & 3.13 \\
\hline Petroleum refining & 3.92 & Aerospace & 2.54 \\
\hline Telecommunications (1994-2002) & 3.9 & Electronics, electrical, equipment & 1.98 \\
\hline Chemicals & 3.28 & Motor vehicles & 1.93 \\
\hline
\end{tabular}

Source: Adapted from Fortune Magazine (1990-2003).

below average rates of return. The relatively good level of innovation linked to low barriers to entry in computing and electronics lead to low rates of profit. And third, traditional sectors have varied performance, with petroleum being above average and motor vehicles below average.

This leads us to conclude that business in general as well as the new technology areas were unable to establish consistent above-median rates of profit due to the lower growth of the world economy and deeper recessions of long wave downswing. Factors linked to long wave downswing that are important include speculative bubble crashes, the difficulty to establish the value of fundamental variables, and excess competition. Competition seems to have increased, since TNC concentration ratios and hence presumably monopoly power has declined lately. Value added of the top TNCs has declined in relation to world GDP. For instance, between 1990 and 2000 value added declined relative to world GDP for the top 10 global TNCs from 1.0 to 0.9 , for the top 20 TNCs from 1.8 to 1.5, and for the top 50 TNCs from 2.9 to 2.8. The largest drop in concentration was for the top 11-20 TNCs. ${ }^{7}$

A relatively high level of effective competition which drives down returns toward (or below) average levels, is emphasized in the literature. For instance. Michael Perelman (2001) argues that the recent expansion of competitive forces promotes overproduction, falling prices, and reduced profitability, while Clem Tisdell (1999) argues that the recent push to enhance competitive pressures and introduce structural adjustment policies reduces resources that can promote corporate diversity, cooperation, positive 
externalities, trust, and planning for an uncertain future. Robert Brenner seeks to explain the demise of system-wide profitability thus:

For the firms, the struggle to cut costs, so as to increase market shares and raise profit, has been fundamental and explains why they had little choice but to concern themselves obsessively with means to improve competitiveness... But, the unintended consequences of their actions has been, first, the reduction in aggregate international profitability..., and then the reproduction of reduced profitability, [international competition has, over the course of the long downturn, proved a zero-sum game,...so that the system-wide profit rate long failed to rise.

(1999:41)

Table 4.6 Global investment, productivity, profit, and GDP, 1950s-2000s, decade annual averages

\begin{tabular}{lrrrrrrr}
\hline & 1950s & 1960s & & 1970s & 1980s & 1990s & 2000-2002 \\
\hline US 500 TNC profit rate $^{\mathrm{a}}$ & 7.71 & 7.15 & 6.30 & 5.30 & 4.02 & 3.30 \\
Global 500 TNC profit rate $^{\mathrm{a}}$ & 5.48 & 3.68 & 3.38 & 2.66 & 2.46 & 1.80 \\
Real global investment growth rate $^{\mathrm{b}}$ & n.a. & 7.78 & 3.97 & 3.24 & 2.24 & 2.1 \\
Global industry value added growth $^{\mathrm{b}}$ & n.a. & n.a. & 3.36 & 2.59 & 1.92 & n.a \\
Global services value added growth $^{\mathrm{b}}$ & n.a. & n.a. & 3.35 & 2.60 & 2.46 & n.a. \\
Real per capita global GDP growth $^{\mathrm{b}}$ & n.a. & 3.19 & 2.11 & 1.27 & 1.05 & 1.00 \\
\hline
\end{tabular}

Source: Adapted from Fortune Magazine ${ }^{\mathrm{a}}$ (1960-2003); World Bank ${ }^{\mathrm{b}}$ (2003).

However, there were many regional variations in terms of the emergence of new nations and even continents into the global situation. In general, one would expect the low rates of profit in the global corporate system to impact on accumulation, productivity, and growth, and vice versa, in a circular and cumulative sense. The data relevant is shown in Table 4.6. This data clearly shows that most growth figures were relatively high during the 1960s, and then consistently and successively declined through the 1970s, the 1980s, the 1990s, and 2000s. Despite the growth engines of FDI, exports, and TNCs, the overall economic performance of the world has become far worse. Clearly, the global corporate system has not succeeded in propelling greater profitability, investment, productivity, and growth during the 1970s-2000s; in fact, the experience is one of worsening performance. Hence, there is no indication whatsoever that a new corporate SSA is being developed at the global level, and therefore one critical aspect of the global SSA is failing to propagate a new long wave upswing. 


\section{Continental contradictions of the transnational corporate system}

The question arises as to what are the dominant continental or regional contradictions that are inhibiting these global corporate engines from propagating high levels of growth, productivity, investment, and profitability. The central contradiction is that the trend to globalization has been ongoing and unstable while certain national accumulation regimes have been in relative stagnation. The growing transnational global penetration was in response to the difficulties of maintaining reasonable levels of regional economic performance in the 1970s and 1980s. But the 1980s-2000s have not reestablished enhanced accumulation in most regional contexts. The rate of growth of FDI, exports, and international capital has to some degree adversely affected certain regional and continental corporate regimes. Indeed, trying to rely on global accumulation without an expansion of continental structures places a major limit on globalization itself. This twoedged contradiction has been critical to the limits of growth and accumulation during the 1970s-2000s.

For instance, evidence points to the positive but weak relationship between FDI and continental/regional investment. The globalization trend and FDI was encouraged during the 1970s-2000s as a possible panacea to the declining levels of investment throughout most national economies. The idea behind this was that expanding global flows and investment would enhance most individual economies. However, the process of uneven growth and development led to a highly concentrated form of growth in parts of Asia and continual deterioration in the advanced capitalist world but more especially in Latin America, Africa, and most transitional economies of Eastern Europe. This relative centralization of growth to Asia has not helped the rest of the world as much as expected. The advanced Western economies appear to be undergoing industrial maturation (and the expansion of services) while Africa and Latin America have been (again) peripheral to the major corporate growth centers.

During 1980-2000, real GDP per capita experienced either negative growth (41 nations) or small growth between 0 and 1 percent (28 nations), while less than 50 percent of nations (65 of them) had growth over 1 percent (UNCTAD 2003a: 57). What this amounts to is a poorly developed corporate accumulation regime in most areas except for East Asia. In the central industrial economies long wave downswing has continued through the 1970s-2000s as industries mature, uncertainty reduces domestic investment, and aggregate demand falters. Latin America experienced slower growth and investment during the 1980s-2000s than during earlier decades, despite putting into practice most of the neoliberal and globalized policies of free markets and capital openness. Even compared to the poor performance of $G 7$ mature nations $(G 7=100)$, the index of Latin American real GDP per capita dropped from 17 (1970) to 13.5 (2000). Sub-Saharan Africa has been unable to make a dent into the industrial markets due to its dependence on agriculture and low value added industries, undesirable world trade rules, as well as an array of wars, conflicts, droughts, and diseases. Its index of GDP per capita $(G 7=100)$ similarly dropped from 3.8 (1970) to 2.0 (2000) (UNCTAD 2003b:58). And the transitional economies of Russia and Eastern/Central Europe mostly have not as yet reestablished the GDP figures of 1990 (Marangos 2004). Global recovery cannot be 
reestablished on the basis of one major continental block (East Asia) experiencing growth and development, since a progressive accumulation regime requires a more general application for global growth and prosperity to be restored.

As mentioned, throughout the 1980s and 1990s, Latin America in general put into place the neoliberal policies of deregulating markets, reducing controls over foreign capital, and reigning in public spending. However, these policies failed to promote private investment or general demand to propel sustained growth and development. Private investment has remained at or below 20 percent of GDP, well below the 25 percent required for sustained growth (UNCTAD 2003b:68). The investment climate is quite volatile in Latin America, subject to major discontinuities, and incompatible with progressive industrial metamorphosis. This is explained by

Table 4.7 Crowding in and out effects of FDI on investment, 1970-1996

\begin{tabular}{lllll}
\hline & Neutrality (No CO or CI) & $\frac{\text { Asia }}{2.71}$ & Africa & Latin America \\
\cline { 1 - 2 } LTI/FDI coefficient & 1.0 & Large CI & Slight CO & Substantial CO \\
LT effect & - & L
\end{tabular}

Source: Adapted from Agosin and Mayer (2000:11).

a combination of FDI crowding out domestic private investment, and the declining trend of public investment (especially in transport and communications) under the influence of neoliberalism.

Manuel Agosin and Ricardo Mayer (2000) studied the extent of FDI crowding out of private investment in Asia, Africa, and Latin America. In particular, they investigated the extent to which FDI promoted backward and forward capital formation linkages. Under the impact of globalization and neoliberalism, all three continents experienced a more rapid growth of FDI in the 1990s than the 1980s, especially through M\&As. The real test was whether this policy was successful in promoting overall investment and hence growth in certain nations and continents. If the long-term coefficient linking FDI with investment is positive then it will be equal at least to unity (1.0), while for crowding out it is less than 1.0, and crowding in greater than 1.0. The conclusions for several continents are summarized in Table 4.7.

The results demonstrate that there was a large degree of crowding in of (domestic) investment by FDI in Asia, a very slight crowding out in Africa, and substantial amount of crowding out in Latin America. Crowding out was especially noticeable in Bolivia, Chile, the Dominican Republic, Guatemala, and Jamaica. Most Latin American governments instigated policies in the 1980s and early 1990s to depend upon FDI for expanding growth and accumulation. FDI increased in Latin America as a percent of GDP from 5.3 in 1983-1991 to 9.5 in 1992-1996 without promoting profit and accumulation for the continent as a whole. As Agosin and Mayer conclude:

The main conclusion that emerges from this analysis is that the positive impacts of FDI on domestic investment are not assured.... Therefore, the assumption that underpins policy toward FDI in most developing 
countries - that FDI is always good for a country's development and that a liberal policy toward [TNC]s is sufficient to ensure positive effectsfails to be upheld by the data. A recent piece of research by one of the authors of this paper reveals that the most far reaching liberalisations of FDI regimes in the 1990s took place in Latin America, and that FDI regimes in Asia have remained the least liberal in the developing world.... Several Asian countries still practice screening of investment applications and grant differential incentives to different firms. [S]ome types of investment have remained prohibited for most of the period under review. Nonetheless, it is in these [Asian] countries that there is strongest evidence of CI. In Latin America, on the other hand, these [restrictive] practices have been eliminated in most countries. Nonetheless, liberalization does not appear to have led to CI.

$(2000: 14)^{8}$

FDI in Latin America has crowded out private domestic investment through an array of mechanisms associated with the unproductive substitution of FDI for national investment. Latin American governments have in general been less prudential in encouraging the more productive FDI activities associated with the establishment of new plant and equipment and new technology areas ("Greenfield investment”). Instead they have encouraged the open slather approach to corporate development. Such an approach-in this context-has encouraged the buying of local real estate, M\&As, the substitution of foreign for local investment, spending in low technology areas, and the repatriation of profits overseas (Lall 2002a:11).

Global growth has also not been stimulated from the ripening of conditions of investment in Africa. African authorities have joined in with the IMF (International Monetary Fund), WTO (World Trade Organization), and highly developed economies in propelling neoliberal strategies for expansion (Owusu 2003). However, the Sub-Saharan African experience is especially unsuitable to this method due to the need to encourage local industry, to go beyond dependence on agriculture and low-technology manufactures, to overcome tension associated with war and conflict, as well as to ameliorate problems of AIDS and malaria. These anomalies have led to an inability to propel domestic accumulation and the effective penetration by transnational as FDI to Africa as a percent of global FDI has declined from 12 percent (1995) to 7 percent (2000) (Wood 2000:56). FDI to Africa thus not only has no net crowding in effect on domestic private investment but has declined markedly in recent years. For instance, African real GDP per capita has remained almost constant during the long wave downswing of 1970 1998 with a per capita average annual GDP growth rate of only 0.01 percent, after having increased during the long wave upswing of 1950-1973 at an average annual rate of 2.07 percent (Maddison 2000:129).

There are three main problems experienced in many Sub-Saharan African regions: a low level of industry structural change, a high level of conflict, war, and disease, and a lack of institutional innovation. First, Africa as a whole has been subject to problems associated with dependency on minerals, agriculture, and low-level manufactures. As the Prebisch-Singer thesis outlined, Africa has been subject to deteriorating terms of trade as their industries have failed to enhance development compared with nations concentrating 
on high-technology products. There are thus critical negative effects of industrial backwardness that enhance uneven development in the world economy. For instance, productivity benefits in metropolis nations tend to accrue to some in the form of rents, while in Africa they tend to manifest in lower prices (Raffer, forthcoming), due to the low income elasticity of demand of African exports.

Second, Sub-Saharan Africa has been subject to high levels of war, general conflict, drought, and disease that inhibit growth and investment. These factors

Table 4.8 Comparative levels of war, disease, instability, and institutional development

\begin{tabular}{|c|c|c|c|c|}
\hline & $\begin{array}{l}\text { Sub-Saharan } \\
\text { Africa }\end{array}$ & $\begin{array}{l}\text { Latin } \\
\text { America }\end{array}$ & $O E C D$ & $\begin{array}{l}\text { East } \\
\text { Asia }\end{array}$ \\
\hline Average years schooling (2000) & 3.5 & 6.1 & 11.9 & 6.4 \\
\hline $\begin{array}{l}\text { Infant mortality (per 1,000 live } \\
\text { births) (1995) }\end{array}$ & 94 & 34 & 7 & 36 \\
\hline $\begin{array}{l}\text { Probability of currency crash in 24- } \\
\text { month period (1965-2001) }\end{array}$ & 49 (Non-CFA) & n.a. & $\begin{array}{l}36.8 \text { (Europe and } \\
\text { Middle East) }\end{array}$ & $\begin{array}{l}24 \\
\text { (Asia) }\end{array}$ \\
\hline $\begin{array}{l}\text { Percent of nations with at least } 1 \\
\text { war (1960-2001) }\end{array}$ & 40 & n.a. & 13 & $\begin{array}{l}24 \\
\text { (Asia) }\end{array}$ \\
\hline Rule of law index (1997-1998) & -0.8 & -0.3 & 1.3 & -0.1 \\
\hline $\begin{array}{l}\text { Absence of corruption index (1997- } \\
\text { 1998) }\end{array}$ & -0.7 & -0.2 & 1.5 & -0.3 \\
\hline $\begin{array}{l}\text { Political stability and peace index } \\
(1997-1998)\end{array}$ & -0.8 & -0.3 & 1.1 & 0.2 \\
\hline
\end{tabular}

Source: Adapted from Rogoff and Reinhart (2002); Wood (2002).

tend to increase the level of risk-and hence financial instability - for both domestic and transnational corporations, which inhibit accumulation and growth. Low levels of accumulation and growth, in their turn, reinforce conflict, disease and instability in a circular and cumulative fashion. Third, there is the relatively low level of institutional development in Africa. In Sub-Saharan Africa the rule of law, peace/stability, protection against corruption, and education have been in a relatively low state of development, as illustrated in Table 4.8. Critical sources of malaise in Africa are thus related to conflict, disease, lack of human capital, financial crises, and inadequate institutional development. These deficiencies inhibit the promotion of human capacities as well as investment and growth. In the early years of the twenty-first century, Sub-Saharan Africa does not represent a sufficient source of productive corporate expansion to promote long wave upswing in the world economy.

The question now arises as to whether the opening up of the transitional economies of Central and Eastern Europe constitutes a positive source of corporate market growth. Table 4.9 gives an overview of the pattern of FDI, domestic investment, and GDP over the period 1990-2002 for the most important of these nations. This table illustrates some important trends for these six critical Central and Eastern European nations. First, 
transnational penetration of production via FDI has increased markedly from 7 percent (1990) to 53 percent (1996) and 88 percent (2001) of private domestic investment. At the same time, domestic investment has more than halved between 1990 and 2002, from US\$387 billion (1990) to US\$156 billion (2002). As a percentage of world investment, investment in these six transitional economies has dropped from 6.4 percent (1990) to 1.9 percent (1996), and remaining low at 2.0 percent (2002). This is quite a remarkable deterioration of domestic investment. A similar drop is discernable for real GDP

Table 4.9 Russia and Eastern Europe: economic
performance, 1990, 1996, 2002

\begin{tabular}{|c|c|c|c|c|c|c|c|c|c|}
\hline & \multicolumn{3}{|c|}{$\begin{array}{l}\text { FDI as percent gross } \\
\text { fixed capital formation }\end{array}$} & \multicolumn{3}{|c|}{$\begin{array}{l}\text { Gross fixed capital } \\
\text { formation (constant } 1995 \\
\text { US \$billion) }\end{array}$} & \multicolumn{3}{|c|}{$\begin{array}{l}\text { Real GDP (constant } \\
1995 \text { US \$billion) }\end{array}$} \\
\hline & 1990 & 1996 & 2001 & 1990 & 1996 & 2002 & 1990 & 1996 & 2002 \\
\hline $\begin{array}{l}\text { Czech } \\
\text { Republic }\end{array}$ & 1 & 7 & 29 & 15 & 18 & $20 *$ & 55 & 55 & 58 \\
\hline Hungary & 4 & 19 & 17 & 9 & 10 & $13^{\mathrm{b}}$ & 50 & 45 & 58 \\
\hline Poland & 1 & 16 & 15 & 16 & 25 & 33 & 99 & 117 & 145 \\
\hline Romania & 0 & 3 & 13 & 7 & 8 & 9 & 40 & 37 & 36 \\
\hline $\begin{array}{l}\text { Russian } \\
\text { Federation }\end{array}$ & 0 & 3 & 4 & 286 & 58 & 68 & 544 & 326 & 394 \\
\hline Ukraine & 1 & 5 & 10 & 54 & 9 & 13 & 102 & 44 & 51 \\
\hline $\begin{array}{l}\text { Total } 6 \\
\text { nations } \\
\text { (\%world) }\end{array}$ & $\begin{array}{r}7 \\
(175)\end{array}$ & $\begin{array}{r}53 \\
(1060)\end{array}$ & $\begin{array}{r}88 \\
(489)\end{array}$ & $\begin{array}{r}387 \\
(6.4)\end{array}$ & $\begin{array}{r}128 \\
(1.9)\end{array}$ & $\begin{array}{r}156 \\
(2.0)\end{array}$ & $\begin{array}{r}890 \\
(3.4)\end{array}$ & $\begin{array}{r}624 \\
(2.0)\end{array}$ & $\begin{array}{r}742 \\
(2.1)\end{array}$ \\
\hline World & 4 & 5 & $18^{\mathrm{b}}$ & 6,014 & 6,721 & $7,869^{\mathrm{a}}$ & 26,301 & 30,158 & 35,065 \\
\hline
\end{tabular}

Source: Adapted from World Bank (2003).

Notes

a 2001.

b 2000.

relative to world real GDP, from 3.4 (1990) to 2.0 (1996), and remaining very low at 2.1 percent (2002). The Russian Federation remains the most powerful Central/ Eastern European nation, and has been experiencing a greater than average decline in domestic investment and real GDP. Clearly, despite some positive trends in some of the smaller nations, there is no real evidence that Central/Eastern European nations are enhancing market growth and accumulation to help propel a new long wave upswing for capitalism into the first decade of the new century. 


\section{Conclusion}

The purpose of this chapter is to ascertain whether a new global corporate social structure of accumulation is being developed to promote long wave upswing into the early years of the twenty-first century. The chapter started off with a discussion of four trends in transnational performance. The first is the high level of globalization over the past couple of decades. The second concerns the new dialectical pattern of competition and innovation. The third is the uneven pattern of growth and accumulation, with the relative movement away from high growth rates in the West and toward especially Asia. And the fourth relates to the development of transnational innovations such as global commodity chains, value added chains, and diversified practices. Then these trends were linked to the three engines of growth for transnational capitals, including FDI expansion, cross-border M\&As, and high-tech manufactures. The geographical engines center on the link between the traditional highly capitalist developed nations and the rising stars of Asia, especially China, Korea, Taiwan, and parts of South-East Asia.

Special reference was then given to the possibility of TNC behavior propelling enough profitability and accumulation to sustain high levels of global growth. We examined various dimensions of profitability between the 1950s and the 2000s, including the profit rate for the largest US corporations, followed by the pattern of profitability for the 500 largest global corporations. The results show that there has, in general, been a declining pattern of profitability from the 1950s and 1960s through the successive decades of the 1970s, 1980s, 1990s, and 2000s. Although the profit rate differs from sector to sector, with the highest being in pharmaceuticals and some of the lowest being in electronics and electrical equipment into the 1990s and 2000s, there is no evidence of a long wave upswing with respect to the profit rate. Then the study turned to the relationship between global and regional investment, profit, productivity, and GDP growth, especially the circular and cumulative link between these four variables. Low and declining trends in these variables are the pattern into the 1990s and 2000s for TNCs.

The chapter examined the potential for certain continental engines of growth to help propel profit, investment, and growth. It was found that the old centers of growth in North America and Europe were still leading the world in terms of absolute levels of profit and GDP, but that Asia is the main player to have joined the club of highly developing capitalist economies. It is proposed, though, that global long wave upswing would require some major advances in other continents as well. For instance, the Latin American experience was in general not positive due to crowding out of domestic investment by FDI, and a declining trend of productive government spending. The experience of Sub-Saharan nations is also not optimistic due to a combination of not being an attractive place for FDI and the continent being plagued by disease, war, drought, and low levels of human and organizational capital. In addition, the transitional economies of Eastern Europe have not seen a major improvement in domestic investment and growth, even as TNCs increasingly dominate there.

Overall, the global corporate system is at best in a transitional phase where the conditions for profit, accumulation, and growth are not optimistic for long wave upswing in the early years of the twenty-first century. There are too many contradictions in the 
system, including the inability of FDI to propel domestic investment in many places, limited conditions for attracting any sort of investment in other areas, and the process of dislocation not being sufficiently overturned in further areas. The great corporate revolution in technology, innovation, and FDI is at present apparently unable to propel sufficient global growth, accumulation, and profitability sufficient for a new era of capitalist transformation. Further changes and renewals are required before a new corporate social structure of accumulation and long wave upswing can be achieved.

\section{Notes}

1 I am grateful to the URPE session participants in San Diego, January 4, 2004, for comments on an earlier and much shorter version of this chapter (see O'Hara 2004), especially Steve Cohn, Jim Devine, Victor Lippit, Reynold Nesiba, Michael Perelman, Michael Reich, and Matt Wilson. The usual caveat applies.

2 Traditionally, SSA scholars have tended to examine the question of long wave upswing within a national context. For instance, in relation to the development of a corporate SSA, Bowles and Edwards (1998) scrutinized the dual corporate economy for the United States. This current research seeks to apply the notion of SSAs to the global economy, including the dominant continents and nations, rather more like the regulation school of political economy. In any case, it is clear that the period of the twenty-first century is more global and regional than simply national, and this tends to justify the current approach of trying to apply the SSA approach beyond national borders.

3 In fact, as Wil Hout (2004) argues, recent trends have not just seen more globalization, but also regionalization and generally also uneven development in the world economy. He shows that financial and trade patterns have become quite global, but that the "global trading system" is dominated by the triad of Western Europe, North America, and East Asia; hence "the world" is very uneven in its patterns and practices. Overall, then, it is a highly uneven and regionalized global political economy where the role of the state remains important in critical cases.

4 The classic statement of this Schumpeterian-(Marxian-Sinithian)dialectic between innovation and competition is that of John Cantwell and Grazia Santangelo (2000). The development of tacit capabilities and technological as well as institutional innovations expands the rate of profit. But this process can only continue if competition pushes firms to continually innovate so as to create new sources of potential profitability. But the two interactive processes of innovation and competition are critical to the process; they both must continually expand so as to reinvigorate capital accumulation. In recent years, intercorporate strategic alliances between firms, regional/local clusters of innovative activity, and intra-corporate networks of knowledge and learning have been critical to the central processes.

5 See Peter Gibbon (2000) and Gary Gereffi (1999) on global commodity chains. Global commodity chain are said to be important to the current expansion of East Asia relative to many other areas, particularly due to the importance of apparel commodity chains. The center of gravity of the contemporary apparel global commodity chain is China, followed by Mexico and Hong Kong, followed by South Korea, Taiwan, and the Dominican Republic. Much emphasis is given to the role of these nations as the producers and the United States in particular as importer of apparel merchandise.

6 The data revision is related to the fact that in 1994 the Fortune 500 largest US industrial corporate list was merged with the 500 largest US service corporate list, resulting in a relative diminution of the rate of profit because service companies (especially financial institutions) typically achieve a very low rate of profit. Generally, the industrial company list is about two and a half times the service list, and the combined list was about 40 percent 
below the usual (industrial) list. Hence the adjustments to the industrial list for the 1950s1993 was made by multiplying the 1994-2002 rate of profit by 2.5 to get the "adjusted" rate of profit for the largest 500 companies. Similar adjustments were made to other tables for the rate of profit, including US large companies and global large companies.

7 See UNCTAD (2002b). While concentration ratios declined for the largest $50 \mathrm{TNCs}$, for the category size 51-100 concentration ratios rose from 3.5 (1990) to 4.3 (2000). This indicates that the competition increased for the largest TNCs, but not for those that are of moderate size. (See Louca and Mendonca 2002.)

8 The authors go on to say that:

Latin America is the great disappointment. One reason for $\mathrm{CO}$ in that region is that overall investment has been much weaker in Latin America...than in Asia. It could also be that Latin American countries have been much less choose about FDIK than Asian countries, either in the sense of prior screening or attempting to attract desirable firms.

(Agosin and Mayer 2000)

\section{References}

Agosin, Manuel R. and Ricardo Mayer. (2000) Foreign Investment in Developing Countries: Does it Crowd In Domestic Investment? UNCTAD Discussion Paper No. 146. New York and Geneva: UNCTAD.

Backer, Koen de and Leo Sleuwaegen. (2003) Does Foreign Investment Crowd Out Domestic Entrepreneurship?, Working Paper No. 618, Department of Economics and Business, Universitat Pompeu, Spain.

Bowles, Samuel and Richard Edwards. (1998) Understanding Capitalism: Competition, Command and Change in the U.S. Economy, Third Edition, New York: Harper Collins.

Brenner, Robert. (1999) “Competition and Class: A Reply to Foster and McNally,” Monthly Review, Volume 51, Number 7, December, pp. 2444.

Cantwell, John and Grazia D.Santangelo. (2000) "Capitalism, Profits and Innovation in the New Techno-Economic Paradigm,” Journal of Evolutionary Economics, Volume 10, pp. 131-157.

Cohn, Theodore. (2000) Global Political Economy: Theory and Practice, New York: Longman.

Dicken, Peter. (2003) Global Shift: Reshaping the Global Economic Map in the 21st Century, Fourth Edition, London and New Delhi: Sage Publications.

Federal Reserve System (Board of Governors). (2000) Long-Term U.S. Government Securities: 1925-2000. (Discontinue Series.) http://www.forcastes.org/data/data/\%20LTGOVTBD.htm (accessed June 15, 2004).

Federal Reserve System (Board of Governors). (2003) Flow of Funds Accounts for the United States: Annual Flows and Outstandings, 1945-2002, Washington, DC: FRS, September.

Federal Reserve System (Board of Governors). (2004) Rate of Interest: Long term or Capital Market: Government Securities: Ten Year, http://www.federalreserve.gov/\%20h15/data/a/tcn10y.txt (accessed July 26, 2004).

Fortune Magazine, 1955-2003 (various issues).

Gereffi, Gary. (1999) "International Trade and Industrial Upgrading in the Apparel Commodity Chain,” Journal of International Economics, Volume 48, pp. 37-70.

Gibbon, Peter. (2000) "Upgrading Primary Production: A Global Commodity Chain Approach,” World Development, Volume 29, Number 2, pp. 345-363.

Gordon, David M. (1980) "Stages of Accumulation and Long Economic Cycles," in Terrence K.Hopkins and Immanuel Wallerstein (eds), Processes of the World-System, New York: Sage 
Publications, pp. 9-45. Reprinted in David Gordon (1998), Economics and Social Justice: Essays on Power, Labor and Institutional Change, edited by Samuel Bowles and Thomas Weisskopf, Cheltenham, UK: Edward Elgar, pp. 93-129.

Hout, Wil. (2004) “A Global Economy, Polycentric World or System of National States,” in Phillip Anthony O’Hara (ed.), Global Political Economy and the Wealth of Nations: Performance, Institutions, Problems and Policies, London and New York: Routledge.

Kessides, Ioannis N. (1990) "The Persistence of Profits in the U.S. Manufacturing Industries," in Dennis C.Mueller (ed.), The Dynamics of Company Profits: an International Comparison, Cambridge: Cambridge University Press, pp. 59-75.

Lall, Sanjaya. (2002a) Implications of Cross-Border Mergers and Acquisitions by TNCs in Developing Countries, QEH Working Paper No. 88, June.

Lall, Sanjaya. (2002b) "Linking FDI and Technology Development for Capacity Building and Strategic Competitiveness,” Transnational Corporations, Volume 11, Number 3, pp. 39-88.

Louca, Fransisco and Sandro Mendonca. (2002) "Steady Change: The 200 Largest US Manufacturing Firms Throughout the 20th Century,” Industrial and Corporate Change, Volume 11, Number 4, pp. 817-845.

Maddison, Angus. (2000) The World Economy: A Millennial Perspective, Paris: OECD (Development Centre Studies).

Marangos, John. (2004) “Transformation to a Market Economy in Eastern Europe, the Former Society Union and Asia,” in Phillip Anthony O'Hara (ed.), Global Political Economy and the Wealth of Nations: Performance, Institutions, Problems and Policies, London and New York: Routledge.

Mueller, Dennis C. (1990). “The Persistence of Profits in the United States,” in Dennis C.Mueller (ed), The Dynamics of Company Profits: An International Comparison, Cambridge: Cambridge University Press, pp. 35-57.

OECD (Organisation for Economic Co-operation and Development). (2001) New Patterns of Industrial Globalisation: Cross-border Mergers and Acquisitions and Strategic Alliances, Paris: OECD.

O’Hara, Phillip Anthony. (2004) “A New Transnational Corporate Social Structure of Accumulation for Long Wave Upswing in the World Economy?,” Review of Radical Political Economics, Volume 36, Number 3, Summer, pp. 328-335.

Owusu, Francis. (2003) "Pragmatism and the Gradual Shift from Dependency to Neoliberalism: The World Bank, African Leaders and Development Policy in Africa," World Development, Volume 31, Number 10, pp. 1655-1672.

Perelman, Michael. (2001) “Competition: The Hidden Costs of the Invisible Hand,” Challenge, Volume 44, Number 2, March-April, pp. 85-124.

Raffer, Kunibert. (Forthcoming) “Terms of Trade and Development,” in Phillip Anthony O’Hara (ed.), International Encyclopedia of Public Policy: Governance in a Global Age, Volume 4, London and New York: Routledge.

Rogoff, Kenneth and Carmen Reinhart. (2002) FDI to Africa: The Role of Price Stability and Currency Instability, IMF Working Paper, Washington, DC: IMF, August.

Tisdell, Clem. (1999) "Diversity and Economic Evolution: Failures of Competitive Economic Systems,” Contemporary Economic Policy, Volume 17, Number 2, April, pp. 156-165.

UNCTAD (United Nations Conference on Trade and Development). (2002a) World Investment Report 2002: Transnational Corporations and Export Competitiveness, New York and Geneva: United Nations.

UNCTAD. (2002b) “Are Transnationals Bigger than Countries?” http://r0.unctad.org/en/\%20press/pr0247en.htm (accessed October 13, 2003).

UNCTAD. (2003a) FDI in Least Developed Countries at a Glance, New York and Geneva: United Nations.

UNCTAD. (2003b) Trade and Development Report, 2003: Capital Accumulation, Growth and Structural Change, New York and Geneva: United Nations. 
UNCTAD. (2004) World Investment Report 2004: The Shift towards Services, New York and Geneva: United Nations.

Wood, Adrian. (2002) Could Africa be Like America? Department for International Development, Working Paper, London: DFID, April.

World Bank. (2003) World Development Index Database, Washington, DC: World Bank. Access limited by subscription. 


\section{5 \\ A global money-trade-production mode of regulation?}

\section{Introduction}

This chapter ${ }^{1}$ examines the third aspect of the Global System of Power and Accumulation: the degree to which a new global mode of regulation (MOR) has emerged which may help to promote long wave upswing in the world economy. A series of institutional proxies are employed in this chapter. Attention is given to the systemfunctions of global productivity and demand, through the performance of the prevailing system of production-distribution (SPD); global financial stability, proxied by the operations of the International Monetary Fund (IMF); and global conflict resolution over trade issues, proxied through the workings of the World Trade Organization (WTO).

The nations of the world have experienced much instability of the political economic environment over the past decade. Russia and many other transitional economies have been undergoing a tumultuous series of shocks to the institutional fabric through revolution, dynamic change, and uncertainty toward market capitalism. Sub-Saharan Africa has been experiencing a series of droughts, famines, and wars, as well as an AIDS epidemic that has sapped the energy of the continent. Mexico, Asia, Russia, Brazil, Turkey, and Argentina have suffered from Earthwrenching financial and economic crises, resulting in recession. Japan has undergone three recessions since its massive asset-price collapse of the early 1990s. Many nations griped through the deep recession of the early 1990s through to the US-led speculative excesses and successive slumps of new technology stocks, along with recession during 2001-2002. And there have also been a series of regional wars, coups, and terrorist attacks from Iraq-Kuwait through to IsraelPalestine, Kashmir, the Sudan, Bosnia, Chechnya, Eritrea-Ethiopia, Fiji, the Solomon Islands, New York City, Washington, DC, Bali, Morocco, Madrid, London, and Afghanistan.

Many people recognize that these instabilities have been greater during the last decade than the 1970s and 1980s. Certainly, the financial-economic crises have become more extensive and intense of late, as the evidence of Little and Olivei (1999:55) clearly shows. From these crises have emerged a large number of policy proposals for a "new international financial architecture," particularly for the promotion of stability through reform of the IMF. Also, over recent years there have been mounting demonstrations in the United States, Europe, Australia, and elsewhere against the globalization trend and the neoliberal institutions of the IMF, the WTO and the World Economic Forum. The WTO, for instance, has come in for much criticism (from within and without) for being apparently oblivious to environmental, labor and health issues associated with trade. The (post-)New Millennium Round of discussions for WTO members is thus set for 
protracted debate and conflict before a new series of agreements can be formulated, not to mention activated. And the prevailing systems of production-distribution associated with information technology, just-in-time, and total quality management are undergoing halting progress toward the required levels of productivity and demand for a new phase of capitalist development.

Do the massive instabilities of the 1990s-2000s represent the continuation of long wave downswing into the early years of the twenty-first century? Alternatively, are we seeing the start of a long wave upswing, despite the global instabilities? These questions are the subject of this chapter. Specifically, I explore whether a new global productionmoney-trade MOR has emerged to provide a foundation for long wave upswing in the world economy. If this global MOR has developed for long wave upswing then both the recessions and financial instabilities will be less extreme because the floor of the short business cycle has been raised and uncertainty reduced.

The crux of the main global aspects of the regulation approach is illustrated in Figure 5.1, shown as a "centered totality." The regulation approach is especially helpful because it recognizes the centrality of the regime of accumulation in the analysis; this includes the link between the question of a new production style (which may enhance productivity) and the mode of consumption (which may enhance demand). Both elements are said to be critical to the emergence of long wave upswing. Sufficient productivity and demand sustain growth in the long term, and lessen the depth of recession. Other factors influence the rate of profit, such as wage rates and material costs, but they lie outside the scope of this specific chapter and relate to other structural forms such as nationally oriented capital-labor relations and global input prices. Also, in the current environment, the costreducing strategy of business may promote the health of certain industrial

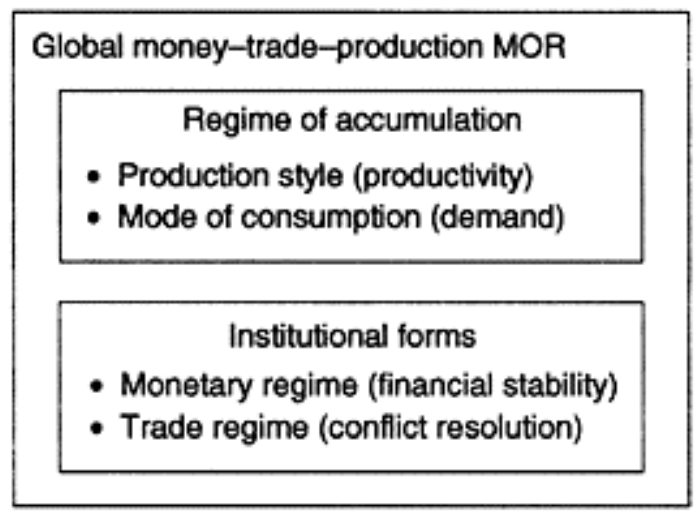

\section{Figure 5.1 The global money-trade- production MOR.}

capitals, but not necessarily the circuit of social capital, as a cost-reducing strategy needs to be supplemented by a demand-enhancing regime to sustain long wave upswing. For instance, wage reductions are both a cost reduction as well as a potential drop in demand. Hence, in this chapter the question of a new global regime of accumulation that enhances 
productivity and demand is given priority in the Kaldorian-style cumulative dynamics that are embedded in much regulation analysis nowadays (see Pini 1995).

But we must not ignore the global institutional forms (what regulation scholars often call "structural forms") that may enhance financial stability and conflict resolution. In this context, the obvious candidates are the IMF (for financial stability) and the WTO (for conflict resolution over trade issues). Such institutional forms may enhance the long-term reproduction of the system through providing global institutional supports or public goods functions. Therefore, while it is central to have a new and thriving regime of accumulation, the institutional forms are an important part of the overall analysis of the more general global MOR.

This is complementary to the social structure of accumulation (SSA) analysis, as illustrated in Figure 5.2, as a "decentered totality." In the SSA approach, all three systems - propelling (a) productivity/demand, (b) financial stability, and (c) the resolution of conflict resolution over trade issues-would be linked to social structures of accumulation and given approximately equal importance. The individual (micro) global (potential) SSAs of production-distribution, finance, and trade thus would be of equal theoretical and empirical importance in the global SSA, while in the regulation approach the regime of accumulation is given a privileged position. The latter position is justified I believe because the regime of accumulation-embedded in the prevailing systems of production and distribution-is a far more complex, foundational, and core element of the global circuit of social capital than the money and trade regimes, since it provides the basis of productivity and demand, the critical ends of capitalism that propel growth. The SPD is not an institution in the same sense as the IMF and the WTO; it is more complex, corporate, and critical in its system-functions for capitalism. Nevertheless, both approaches_-SSA and MOR-require us to examine in depth the institutions and institutional spheres that propel the system-functions of productivity and demand, financial, stability, and conflict resolution.

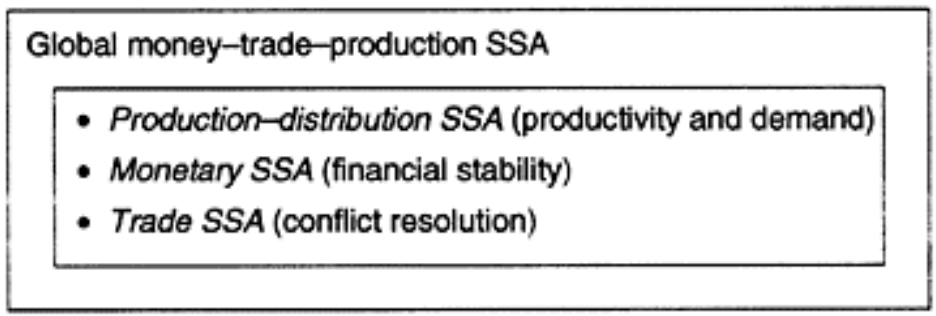

\section{Figure 5.2 The global money-trade- production SSA.}

The chapter thus commences with a theoretical and historical introduction to SSA and regulation approaches to long waves of socioeconomic growth and development, paying particular emphasis to the central requirements for upswing. Then we scrutinize the regime of accumulation (the production-distribution SSA) and whether sufficient productivity and demand emanate from its dynamic performance in the global political economy. The following section closely analyzes the degree to which the institutions 
associated with the IMF are enhancing financial stability through its current programs and innovations. After that we examine the institutionalized success of the WTO in promoting sufficient conflict resolution.

\section{Global circuit of social capital and long waves}

This chapter seeks to critically evaluate the hypothesis of long wave upswing in relation to the workings of the prevailing SPD, the IMF, and the WTO that collectively may constitute a "global production-money-trade MOR" or "global production-money-trade SSA." Linked to this is the notion that the establishment of a new long wave upswing represents a qualitative change of the institutions involved in the circuit, illustrated in Figure 5.3.

The global circuit of social capital illustrates the phases and stages involved in the general motion of social capital in the global political economy (see Palloix 1977 for more detail). All the phases of the circuit interlink in a complex cybernetic network of motion. Money and credit $(M)$ are required to stir the process to action, via internal corporate revenue, financial institutions, and central banks. These largely endogenous sources of funds, propelled by the demand for finance, activate the global sourcing of labor power (LP) and means of production (MOP). This enables global production value chains to be formed $(\ldots . . . . . . .$.$) , thereby enhancing the process of valorization,$ resulting in the production of surplus product. For this surplus product to be transformed into surplus value the resulting commodity value $(C)$ and surplus product $(c)$ must be sold on the market for value $(M)$ and surplus value $(m)$ to be realized via (global) trade. Each of the four phases of the global circuit-finance, sourcing, production, and sale-are institutionally linked through corporate, financial, and governance structures, and processes.

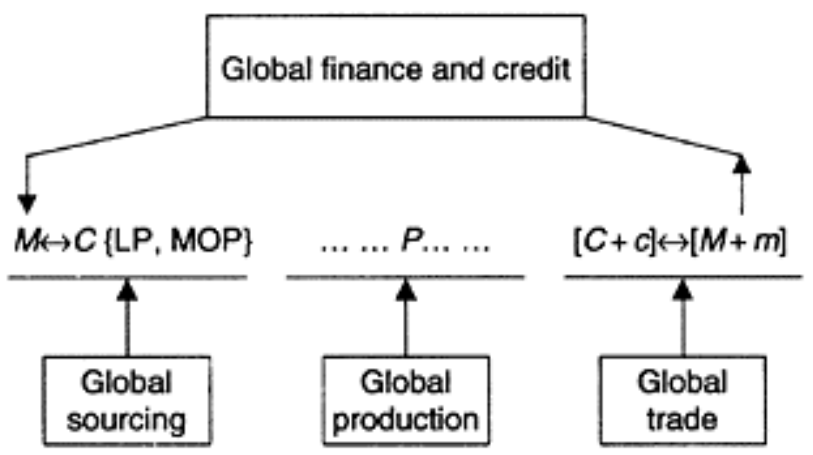

Figure 5.3 The global circuit of social capital.

The regulation and SSA schools of political economy argue that this global circuit cannot operate through purely market arrangements, and that networks of institutions provide the organizational network and social capitals upon which long-term economic 
performance is based. The global economy especially needs to be embedded in a series of institutional organizations, agreements, bodies, and dynamic structures of finance, sourcing, production, and trade in order to enhance the workings of the complex circuit. The conditions necessary for a new SSA or MOR within the global circuit are multifarious, ranging from a suitable level, quality, and price for the inputs of labor power and means of production; the effective mobilization of labor and machines within the production process; a requisite level of global demand and trade; an efficient and relatively stable and sustainable level of money and credit to finance industry; a minimum level of innovative and business spirit of enterprise; and a sufficient supply of support structures and processes to keep the elements of the circuit in motion.

In analyzing the role of global institutions and global public goods to the emergence of a new system of relationships, it is necessary to differentiate between those factors that may propel individual capitals and those that promote social capital as a whole. Also, it is critical to differentiate_as much as is possible-between the factors that have a more national orientation and those of a more global nature. For instance, when the capitalist class is too strong-arguably the situation at present in most nations (see Bettio and Rosenberg 1999; Nilsson 1999)_although costs are reduced to the individual capitals through low wages and bad conditions for labor, this may result in the failure of world income to generate global expansion via underconsumption (see Weisskopf et al. 1985). The capitalist class can also be too weak, as happened during the late 1960s and the early 1970s, leading to low rates of investment and growth. A balance of class forces helps to embed economy in society, thereby enhancing sustained accumulation (see O'Hara 2003). When the emphasis in the prevailing SPD is given to Kaldorian-Thirlwallian notions of higher demand propelling investment, productivity, and world income, dynamic expansion may proceed through the circuit of social capital. Also, vis-à-vis global public goods, reducing financial instability and promoting more conflict resolution can provide a Polanyian-style form of embeddedness for the circuit (see O'Hara 2001a). Given the focus of this chapter, then, a useful working model of the conditions necessary for the establishment of a new global production- money-trade SSA or MOR within the circuit include adequate productivity and demand (for the SPD), sufficient financial stability (for the IMF), and a suitable level of conflict resolution (for the WTO).

Productivity and demand are two crucial factors affecting the growth of the global economy. Production and distribution institutions are required for the long-term expansion of distribution systems that may enhance demand, and through the structures of knowledge and technological capitals which may potentially expand productivity. The workings of the prevailing systems of production and distribution, from a fused regulation-Kaldorian perspective, are illustrated in Figure 5.4 (see Pini 1996). In this Kaldorian-inspired regulation view, demand is the fulcrum around which the productiondistribution circuit of the global circuit is set into motion. Demand can take the form of government spending or 


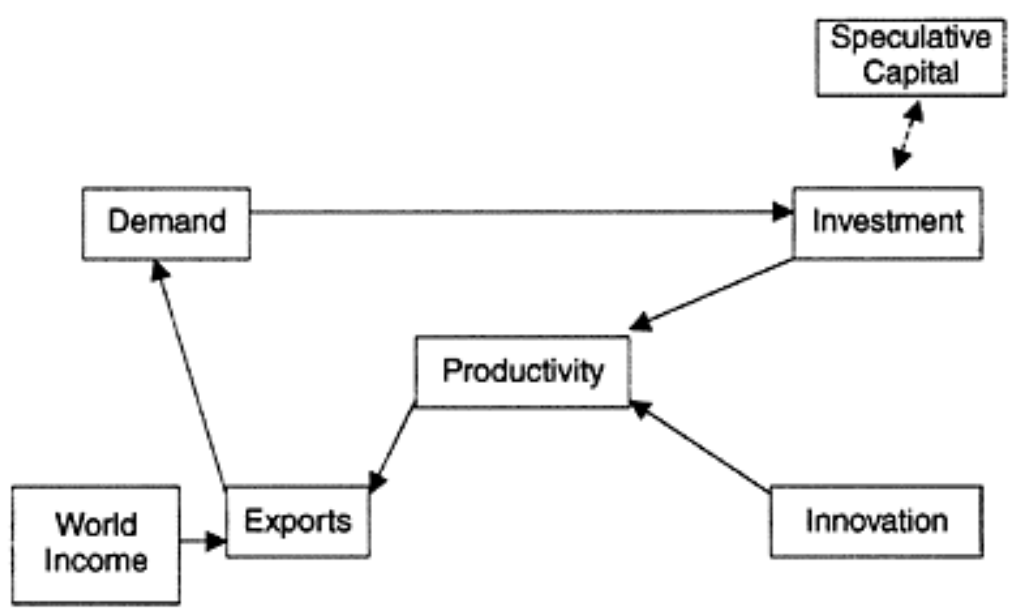

\section{Figure 5.4 Kaldorian dynamics of cumulative causation.}

consumption or endogenous credit, which, given a stable environment for accumulation, can propel investment through a reduction in uncertainty. Some of the demand may leak off into speculative activities, but if this is not the case, investment can become embodied in productive innovation or be set into existing forms of capital. Then through economies of scale/scope, learning by doing, and innovative forms, productivity can increase, which forms the basis of greater exports, and the potential to share these benefits between capital and labor in a sustainable fashion. World income can also expand exports if there is some degree of coordinated policy among nations, which in turn increases exports, and the circuit runs through various cycles in a circular and cumulative fashion.

Financial stability is important in order for the global circuit to propel a sufficiently prudential balancing of power between finance capital and industrial capital, through a moderation of "hot" capital flows. Lately deregulated capital flows, interest rates, and statutory reserves along with computerized credit and electronic funds have led to the emergence of a type of Chartel system of finance where there are few apparent limits to its expansion on a world scale (see Wray 1998; Davidson 2000; Kadmos and O'Hara 2000). Credit is thus endogenously generated through relatively free capital flows, a worldwide system of electronic banking, and the expansion of exotic liability management techniques (Cohen 2001). Such a synchronized and freely flowing system of liquidity management has led to massive balance of payments (BOP) imbalances and financial crises due to a conflict between finance and industry (see Wolfson 1994), and the onus being placed on BOP deficit developing nations bearing the brunt of adjustment through deflation. Leakages from the system of productive capital emanate from such speculative financial activities when bank loans are for short-term purposes such as buying shares or other assets with an eye to short-term gain. Institutional supports are necessary in order to reduce the potential for such financial instability.

A sufficient level of conflict resolution is necessary in the global economy to moderate trade disputes for a new global SSA or institutional form. There are 
Table 5.1 Global MOR/SSA functions, proxies,
capitals, and contradictions

\begin{tabular}{llll}
\hline $\begin{array}{l}\text { SSA/MOR } \\
\text { function }\end{array}$ & $\begin{array}{l}\text { Institutional proxy } \\
\text { or functional } \\
\text { equivalent }\end{array}$ & $\begin{array}{l}\text { Institutionalinnovation } \\
\text { capital }\end{array}$ & Central contradictions \\
\hline $\begin{array}{l}\text { Productivity } \\
\text { and demand }\end{array}$ & SPD & ICT, JIT, TQM & Capital and labor \\
$\begin{array}{l}\text { Financial } \\
\text { stability }\end{array}$ & IMF & CCL, SRF, PINS & Finance and industry \\
$\begin{array}{l}\text { Conflict } \\
\text { resolution }\end{array}$ & WTO & $\begin{array}{l}\text { Agreements, courts and } \\
\text { judgments }\end{array}$ & $\begin{array}{l}\text { Capitals in competition; } \\
\text { national and global } \\
\text { economy }\end{array}$ \\
\hline
\end{tabular}

many global contradictions that require conflict resolution institutions to moderate trade instability through the circuit. The conflicts over trade issues arise from different levels, such as from (a) competition between capitals, (b) conflict between nation states, (c) capital-labor relations, (d) between production and reproduction (system) functions, and (e) between private interests and the ecological environment. These multiple sources of conflict all require the operation of various institutional support networks, accords, forms of trust, and cooperation to resolve some of the more immediate limits to long-term reproduction (see Yeung 1998).

In relation to the structures examined in this chapter, propelling sufficient productivity and demand, financial stability, and conflict resolution over trade issues provide the potential public goods that create socioeconomic embeddedness (Polanyi 1944). The reconstruction of MORs and SSAs requires the development of viable systems of institutions underlying the workings of the global circuit. A summary of the relationships between SSA functions, functional equivalents, institutional capitals, and central contradictions are illustrated in Table 5.1.

The primary requirement for the emergence of a new Global MOR or SSA within the circuit is the propulsion of sufficient productivity and demand through the regime of accumulation, and the institutional forms (or potential SSAs) of global finance and global trade are considered to be supporting structures, respectively, promoting financial stability and conflict resolution over trade issues. The main institutional capitals (discussed in the section on a suitable regime of accumulation) that potentially propel system-functions include information and communication technology (ICT), just-in-time (JIT) methods of inventory management, and total quality management (TQM) in the SPD; the introduction of the Contingent Credit Line (CCL), the Supplementary Reserve Facility (SRF), and Public Information Notices (PINS) by the IMF; and various active trade agreements, court activities, and judgments through the WTO. The primary contradictions that promote potential instability and disarray include the relationship between capital and labor (for the SPD), the relationship between finance and industry (for the IMF), and the relationship between capitals in competition: national and global (for the WTO). The main workings of these three main institutions are explored here in successive sections. Success on all fronts would mean that a new long wave upswing is 
likely to be emerging, at least in relation to these institutional clusters of the global economy.

\section{A suitable regime of accumulation?}

Since the relative demise of the Fordist SPD in the 1970s and the 1980s, evolutionary changes have occurred in this sphere to help solve problems associated with corporate and capital-labor relations, productivity, and demand. As noted in the previous section, at one level this has led to a reduction in the generalized power of workers in the spheres of production and distribution, leading to a decline in working conditions and limits on wages (compared to the 1960s and the early 1970s). Lipietz (1997) calls this a system of "neo-Taylorism," especially prevalent in the United States, Mexico, and the United Kingdom. In Sweden and Germany "negotiated involvement” has been developing, based on codetermination; collective decision-making between labor, capital, and the state; and moderate welfare capitalism. And a large literature exists on the Japanese flexible system of production (see Jessop 2001).

Are we seeing an interdependent, tripartite SPD evolving at the global level, the flexible system in some areas, neo-Taylorism in others, and negotiated involvement in the rest? Or will the flexible system gradually dominate the world of production and distribution? It is difficult to scrutinize this hypothesis. Instead, an alternative hypothesis is explored, what I call the "core institutions" hypothesis. Although the flexible system of production is unlikely to be dominant SPD in the world economy at present, some of its core institutions are emerging strongly, whether in a flexible system context, or in association with neo-Taylorism and negotiated involvement. These three institutions include (a) the just-in-time system of inventory formation, (b) the total quality management method, and (c) the information and communications structure of technology. Evidence supports the notion that these three structures are evolving rapidly in the core enterprises, however these firms are organized (Belussi 2000; Gottardi 2000).

The just-in-time system relates to the elimination of wasted output and time in production within the circuit. Just-in-time requires workplace flexibility in adjusting the amount, kinds, and timing of in-process resources. Minimal use of inventory stock reduces warehouse costs and promotes the smooth flow of production and circulation. This is aided by the structuring of work organization in which job demarcations are minimal and job rotation is maximized (Tomaney 1994:166).

Total quality management facilitates stocks and inferior products being reduced to near zero, potentially enhancing the turnover of the circuit. The flexible mode is often based on niche markets where quality is the number one priority. Also important to total quality management is the " $5 \mathrm{~S}$ " system, which is oriented around making the workplace clean, tidy, orderly, neat, and disciplined; which reduces costs considerably. Another dimension of quality is the emphasis placed on customer relations and rapid production according to special customer needs. Typically with total quality management:

[Workers and foremen] are responsible for checking the specifications of a particular sample of parts in their sections of the production process. Quality control departments back up this on-line inspection (and engage 
in some statistical process control...), and there is the Final Inspection, which...shows up a good many faults. But "Total Quality Management” means something more, of course, than just a system of quality control. It is rather a philosophy of commitment to quality, and to identifying causes of problems that arise, and then tackling them, rather than dealing with symptoms (by correcting faults after they have been made).

(Harriss 1995:120)

Some studies show that total quality management and the so-called Japanese management techniques have occurred in association with greater harmony between capital and labor, higher levels of worker skills on average, and lower levels of worker dissatisfaction. However, many have questioned this idea of multiskilling, reduced worker alienation, and harmony between capital and labor. As Dassbach (1999:111), for instance, concludes: "If anything, the adoption of Japanese techniques leads to further degradation of working life due to under-manning, faster work cycles, the elimination of any vestige of idle time and the elevation of stress levels." The research of Catherine Casey (1999) and Mike Parker (1999) support this view. ${ }^{2}$

Of central importance to the new regime of accumulation is a production-distribution style that may enhance sufficient productivity and demand through greater innovation and export potential. Carlota Perez (1985) and Andrew Tylecote (1992) believe that a new production style is emerging or is in large measure already in place; "a new technoeconomic paradigm.” For Perez, such a paradigm constitutes "a new system of flexible technologies, based on low-cost electronics" (1985:441), while for Tylecote it is a "microelectronics and biotechnology style" (1992:56). An examination of the literature reveals that almost everyone believes that a new system of technology is well and truly in place (see, for instance, Cantwell and Santangelo 2000; Papadakis 2000), even if they are not sure what to call it. Information and communications technologies are a critical part of the new paradigm

There "is a trend towards information intensity rather than energy and materials intensity in production. This stems directly from the very visible change in the general relative cost structure towards ever cheaper information handling potential through microelectronics and digital telecommunication" (Perez 1985:447; see also Tylecote 1992:5). Perez points out that, in product engineering, there is a tendency to redesign existing production systems so that they are smaller, with fewer moving parts, more electronic forms, and less energy intensive. Increasingly, the internet is seen to be critical to these new systems of production and distribution as its use grows from 5 million users in 1993 to 100 million in 1998, with registered sites growing at an annual rate of 40-50 percent (Kenney and Curry 1999:131). Business-to-business e-commerce currently accounts for 90 percent of online trade and is expected to dominate business-to-consumer e-commerce at least in the foreseeable future (Barnett 2000:1). Network externalities promote business interaction and provide considerable benefits to society (Madden et al. 2000:102; Cooper and Madden 2004). ${ }^{3}$

Have the dominant institutions of production propelled productivity sufficiently to contribute to long wave upswing? While information and communications technoloy in particular has aided productivity in its own and related sectors. 
Table 5.2 Labor productivity: global comparisons, 1960-2000 (GDP per hour worked; annual average growth rates)

\begin{tabular}{|c|c|c|c|c|c|c|c|c|c|}
\hline & World & $\begin{array}{l}\text { Major } \\
\text { Europe }^{\mathrm{a}}\end{array}$ & Japan & $\begin{array}{l}\text { United } \\
\text { States }\end{array}$ & Russia ${ }^{\mathrm{b}}$ & Asia & $\begin{array}{l}\text { Latin } \\
\text { America }\end{array}$ & Africa & $\begin{array}{l}\text { Middle } \\
\text { East }\end{array}$ \\
\hline $\begin{array}{l}1960- \\
1973\end{array}$ & 3.2 & 5.0 & 8.0 & 2.6 & 2.0 & 2.2 & 3.3 & 2.6 & 6.4 \\
\hline $\begin{array}{l}1973- \\
1990\end{array}$ & 1.2 & 2.5 & 2.8 & 1.3 & 1.7 & 3.1 & 0.4 & 0.3 & -0.7 \\
\hline $\begin{array}{l}1990- \\
2000\end{array}$ & 1.9 & 2.0 & 2.0 & 1.5 & -4.3 & 4.5 & 1.1 & -0.1 & 0.7 \\
\hline
\end{tabular}

Source: Adapted from van Ark et al. (2004).

Notes

a Excluding transitional economics.

b Former USSR.

this has not generally flowed on to the manufacturing sector, the nation, or the global economy. ${ }^{4}$ The comparative global record is not impressive, as Table 5.2, shows for many nations and continents. Globally, productivity for the 1973-2000 period was about half that of the 1960-1973 period. General macroeconomic productivity declined by more than half in Europe, Japan, Russia, Latin America, Africa, and the Middle East during the 1973-2000 era, and about half for the United States. The only area that experienced a boost during 1973-2000 was Asia. Productivity in the 1990-2000 period was a quarter of the level of 1960-1973 in Japan, a third of the level in Latin America, one-ninth in the Middle East, and it crashed to negative figures during 1990-2000 in Russia and Africa. Overall, then, global productivity levels in recent decades, and especially in the 1990-2000 period, are a pale imitation of the 1960s and the early 1970s. Hence, there is no evidence whatsoever of a sustainable productivity surge, or even a mere improvement, for long wave upswing in the global political economy.

So far we have concluded that insufficient productivity is preventing the emergence of long wave upswing. An analysis of the other side of the regime of accumulation (or production-distribution SSA) — the demand mode — reveals a similar insufficiency. There are major system-faults in the area of global sustainable demand. Two decades of neoliberal policies have put the emphasis on competition and cost rather than demand and cooperative demand management at the global level. Corporate developments have reinforced this trend. Exports are limited by the supply side bias of the system. Government spending is limited by the neoliberal philosophy of cost cutting and reducing public investment. Sustainable investment and consumption are inhibited by a relative dominance of finance capital over industrial capital. The major slump in high-tech stocks in the wake of the 2000-2001 speculative bubble crash intensifies the instability tendencies of the global regime of accumulation or SSA.

During the 1950s and the 1960s, there was a relative balance of power between capital and labor through the major capitalist nations. The power of labor increased relative to capital during the late 1960s and the early 1970s. Since the mid-late 1970s, the power of 
capital has increased significantly relative to labor, which has contributed to a reduction in costs, but at the system-expense of limited demand.

Table 5.3 Demand proxies in the global economy, annual average rate of growth

\begin{tabular}{|c|c|c|c|c|c|}
\hline & 1950-1973 & 1974-1998 & 1971-1980 & 1981-1990 & $1991-2000$ \\
\hline \multicolumn{6}{|l|}{ Real GDP growth per capita } \\
\hline World & 2.93 & 1.33 & 1.8 & 1.3 & 1.2 \\
\hline Europe & 4.08 & 1.78 & 2.7 & 2.1 & 1.7 \\
\hline Advanced capitalist nations & 3.72 & 1.98 & 2.6 & 2.5 & 1.8 \\
\hline Latin America & 2.52 & 0.99 & 3.3 & -0.9 & 1.7 \\
\hline Eastern Europe and Russia & 3.49 & -1.10 & 2.9 & 0.6 & -1.8 \\
\hline Africa & 2.07 & 0.01 & 0.7 & -1.1 & -0.2 \\
\hline East Asia and Pacific & 2.61 & 4.18 & 4.6 & 5.6 & 6.4 \\
\hline \multicolumn{6}{|l|}{ Investment growth } \\
\hline Advanced economies & 6.8 & 3.5 & $3.3^{\mathrm{a}}$ & $4.0^{\mathrm{b}}$ & $3.8^{\mathrm{c}}$ \\
\hline $\begin{array}{l}\text { Source: Adapted from IMF } \\
\text { Notes } \\
\text { a } 1973-1987 . \\
\text { b 1983-1992. } \\
\text { c 1993-2001. }\end{array}$ & 2004:281); & ddison (2001 & & & \\
\hline
\end{tabular}

The US solution to this demand problem in the 1990s (in the light of current account deficits) was an increase in capital inflow, expanding technology stocks, and wealth. This led to more debt and-through the "wealth effect"-increased consumption, and hence the gross domestic product (GDP). But this growth was only of a short-run duration because it was based, during the late 1990s and the early 2000s, on speculative bubbles in the equity market, with the NASDAQ crashing by 80 percent, the S\&P500 Index falling by 50 percent, and eventually demand and therefore GDP resulting in recession (see O'Hara 2002, 2003). The demand proxies examined in Table 5.3-output and investment growth-illustrate the situation of inadequate global demand, and getting worse in the early 2000s (although some degree of short-term recovery seems to be emerging in the 2004-2006 period in some nations).

The rate of global per captia output growth during the long wave upswing of 19501973 was about double that of long wave downswing of 1974-2000s. Similarly, in the advanced economies, the most important aspect of demand-investment growth-has been in the doldrums. Investment growth in the 1950s-early 1970s was about double the rate of the 1970s-2000 period. Since the 1970s, successive decades have not seen a reestablishment of high growth rates of investment. Thus the 1993-2001 period was not, on balance, a period of demand expansion. Neoliberalism and the mode of demand have thus not restored the global conditions of demand required for a long wave upswing. 
It thus cannot be said that a new relatively unified global production SSA or regime of production-distribution, or even one which is heterogeneous, is sufficiently evolved at this point in history to promote sustained productivity and demand for the global circuit (see Pietrykowski 1999). At present, the performance of the global systems of production-distribution-proxied by productivity and demand-do not support sustained upswing. ${ }^{5}$ Hence, neither side of the regime of accumulation is sufficiently well developed to promote sustained upswing in the global economy, with minor recessions (except in East Asia). The question now arises as to whether the "structural forms" (institutional spheres) of the IMF and WTO are promoting sufficient financial stability and conflict resolution, respectively, so as to promote- to the extent that they can - the global circuit of social capital.

\section{IMF money regime and financial stability}

The question of whether the IMF is currently enhancing financial stability sufficiently to be contributing to a new global financial SSA will now be explored. The operational dynamics of the IMF are used as a proxy for financial stability in the world economy. This function is critical because it is necessary to have the development of certain institutional capitals to provide the public goods role necessary to long-term growth and accumulation of capital. This is due to the ever-potentially unstable contradiction between finance and industry. As Marx (1894: chs 30-33) recognized, if financial capitals become more powerful than industrial capitals - especially at the global levelthen the speculative bubbles that deviate from fundamental values create much systeminstability (see O'Hara 2000b). The use of qualitative measures of global financial stability is common in the examination of institutions. Specifically, it will be assessed as to whether the IMF's changing role over the past twenty years is at present contributing significantly to potential financial stability in the global economy, and hence moderating this contradiction.

The IMF in the old 1950s-1970s regime was organized to assist Bretton Woods signatories in managing their balance of payments under a system of fixed exchange rates. With the collapse of generalized fixed rates in the 1970s, and the further evolution toward more flexible rates in the 1980s and the 1990s, the direction of the IMF has changed. After the 1980s debt crises and the 1990s financial and economic crises in the “developing world," the IMF's current concerns are to assist developing nations that undergo crises of confidence or have difficulty paying off their debt. Its main institutional function has thus changed systemically (or widened) during the so-called Kondratieff downswing of the 1970s-1990s (at least), when recessions were generally deeper and financial instability more extreme (Kadmos and O’Hara 2001).

There is little doubt that, during the early-mid-1990s, the IMF was functioning well within the evolving fabric of neoliberal doctrine. It was providing balance of payments support, where required, for developing and emerging economies that made sufficient progress toward deregulating finance, labor and state sectors so as to ensure that "private initiative" was promoted. This fitted well within the (neoliberal) "Washington Consensus" of encouraging nations to “(a) pursue macroeconomic stability by controlling inflation and reducing fiscal deficits; (b) open their economies to the rest of the world 
through trade and capital account liberalization; and (c) liberalize domestic product and factor markets through privatization and deregulation” (Gore 2000:789-790).

However, the crises of the 1990s convinced many analysts and policymakers that financial liberalization and innovation usually propel greater instability through endogenous credit and risk (see Spotten Visano 2003) and that the experience of the 1990s necessitates greater financial stability in the international financial architecture. The Russian collapse of confidence in the 1990s taught many that it is not sufficient to have a "cold turkey" approach to market-based reforms. Rather, markets need to be embedded in a system of suitable institutions, organizations, and legality (see Stiglitz 1999). The six major financial crises of emerging and transitional economies of the 1994-2002 period in Mexico (1994-1995), Asia (1997-1998), Russia (1998), Brazil (1999), Turkey (2001), and Argentina (2001-2002) reinforced the need for fundamental change in the international financial architecture so as to embed economy within society (see Allen 2004 for critical papers on the crises). As Little and Olivei from the Federal Reserve Bank of Boston concluded about the crises of the 1990s:

[There are] potential flaws in the current international monetary system that may warrant more fundamental change. For instance, the characterization of some of these crises as financial panics has strengthened the case for effective international lender of last resort. And the massive reversals in short-term capital flows that triggered these collapses have prompted calls for developing countries to reconsider the risks of open capital markets and the merits of capital controls. Indeed, the recent crises have forced both academic economists and policymakers to question some of their most basic assumptions about the appropriate design of the international monetary system.

(1999:53; emphases added)

An increasing number of economists and policymakers broadly agree with this conclusion, and, as a result, many authors have advocated a new system or substantial reform of the financial architecture (e.g. Blinder 1999; Cooper 1999 Eichengreen 2000; Woods 2000; Cooper 2002; Cartapanis and Herland 2004).

There are some broad similarities between these proposals. First, there is agreement that hot capital flows have been a major problem. For instance, in the Asian crisis private capital flows increased from \$24 billion in 1990 to \$62 billion in 1996 and then decreased to \$20 billion in 1997 (Little and Olivei 1999:61). The main problem relates to hot capital flows that constitute endogenous, short-term sources of credit from overseas earmarked in US dollars. These flows increased the instability of the global system, manifesting in large booms followed by financial crises and deep recessions. The Asian boom crisis and the US boom slump are classic examples of these phenomena ( $a$ la Minsky). ${ }^{6}$

This hot capital flow problem has led many to call for an expansion of capital controls, especially for emerging and developing nations, since "the social implications of freeflowing financial capital [are] too obvious to ignore even for economists" (Eichengreen 2000:206). Many look to the 1990s Chilean policy of prudential controls on foreign short-term capital inflows, which tend to lengthen the maturity of foreign debt. Major 
changes in capital flows will ultimately affect the exchange rate, which can be a major disturbance to long-term investment. Hence, due to the tendency of foreign creditors to periodically panic in transitional and emerging economies with open capital marketscreating herd behavior, speculative bubbles, and contagion-Malaysia, Thailand, China, and many other nations tightened controls over foreign money capital (Cooper 1999:23). Controls on inflows can reduce capital and exchange rate instability, excessive debt and, to some degree, stabilize long-term investment. This is especially needed when nations have not implemented proper regulations and institutional structures for a strong financial sector. Thus, "premature liberalisation runs the risk of leaving a developing country hostage to the whims of a handful of international investors, whose priorities need not coincide with a country's long term development goals” (Little and Olivei 1999:76).

There seems to be some agreement that emerging nations should be wary of liberalizing their capital account and financial system and cutting government spending without suitable institutions for protecting the poor, and monitoring the soundness, transparency, and prudential health of their banking systems (see Cooper 1999:17). Thus, some basic reforms that many agree on include "sound macroeconomic and financial policies: protecting the poorer segments of society, providing better and more fundamental bank supervision, proper accounting standards," and the like (Blinder 1999:58). The "blueprints" that the IMF adhered to, by advising austerity and cutting budgets, are considered to be misguided. As Eichengreen said:

What is unambiguous is that support for reform can be buttressed by strengthening the safety net for social groups most at risk Avoiding counterproductive conditionality may not be enough: in addition, positive steps to strengthen the safety net for those placed at risk...may be essential to maintain political support for reform.

(2000:218)

Indeed, the IMF seems to have learnt the lesson and has fundamentally revised its austerity policies and blueprints in respect of the needs of the poor. Its recent Managing Directors speak of the IMF's recently acquired focus on the "fight against extreme poverty [which] has gained centre stage in our programs," the importance of "civil society," while the Enhanced Structural Adjustment Facility has become "transformed" into the new Poverty Reduction and Growth Facility (Camdessus 1999). Reducing poverty provides a powerful safety net that reduces the negative influence of debt, and hence moderates financial instability and crises.

The IMF and other organizations have also been acting quickly to promote a stronger system of bank supervision and regulation, better accounting standards and adequate information transfer, and transparency (see IMF 2003). The Basle Committee's Core Principles (1997) and the IMF's Toward a Framework for Financial Stability (1998) set the conceptual scene for policies to promote financial stability. We have seen the recent (March 1999; see IMF 1999a, b) strengthening of the IMF’s Special Data Dissemination Standard (SDDS, introduced in 1996). Nations are now required under SDDS to provide detailed information on reserve assets and liabilities and other possible drains on reserves. They are also required to submit their data monthly with a maximum lag of one month; and a separate category was introduced for external debt. PINs were also 
introduced in late 1997, wherein detailed information about the state of a member's economy is made public. Many other proposals are in operation, such as the IMF's Code of Good Practices on Fiscal Transparency; and the Financial Stability Forum (established 1999), to promote international financial stability through information exchange and cooperation in financial supervision and surveillance (see IMF 2000). A host of other recent changes have been adopted by, for instance, the International Accounting Standards Committee and the International Organization of Securities Commissions (see Fischer 1999). These all relate to the basics, such as prudential supervision, transparency, information, and accounting standards.

However, due to problems of excess volatility and contagion, more extensive reforms have begun to be instituted which resemble to some minimal degree the operations of an international lender of last resort (ILLR), although, strictly speaking, the IMF cannot create global money as such (Aglietta 2001). Two institutional innovations are of particular importance: the supplementary reserve facility (SRF) and contingent credit line (CCL).

The SRF was introduced at the end of 1997 for IMF members already in a financial crisis. It provides substantial short-term loans at penalty rates, subject to policy conditionality, for nations with major BOP anomalies due to a large short-term funding need caused by a sudden and destabilizing loss of market confidence. This facility is immediately available when there is a threat of contagion and a likelihood that early help could result in the correction of the BOPs problem. Nations in crisis are encouraged to seek other creditors. SRF funds are available for up to 1 year, with the possibility of 2 or 3 drawings, with repayment expected within 12-18 months, and with a possible extension for a further 12 months. A penalty surcharge (above normal IMF loans) initially of 300 basis points is applied so as to reduce moral hazard, with the rate increasing through time to a maximum of 500 basis points. These funds have been used quite extensively. For instance, Korea used the facility for US\$9.5 billion in 1997, Russia used the SRF funds to the tune of US\$4 billion in 1998, Turkey to the amount of US\$5.8 billion in 2000, Argentina for US\$6.1 billion in 2001, and Brazil used combined SRF/Standby arrangements three times during 1998-2002 for a total of US\$52.5 billion (IMF 1998; RBA 2004).

The CCL, on the other hand, was introduced in April 1999, and deepens the role of the ILLR by providing funds to countries that are experiencing contagion. Subject to policy conditionality, these funds were to be made available automatically as soon as the contagion sets in. The idea behind the CCL is that these funds are crucial to nations that have a good record of macroeconomic and prudential safeguards, and where the adverse workings of international capital markets could be catastrophic for a nation or area through no real fault of their own. It is supposedly an insurance policy against potential future circular and cumulative runs on the currency and socioeconomic dislocation. There are no general access limits to the CCL, but IMF commitments are expected to be in the range of 300-500 percent of the nation's IMF quota. CCL credits have a penalty rate and are expected to be repaid within one and a half years, although extensions beyond this are possible. Also, a country wishing to join the CCL scheme should have subscribed to the SDDS, have good relations with private creditors, have a good economic and financial program, and have received a positive assessment from the IMF at its last "Article IV consultation” (IMF 1999b). The CCL was a standby arrangement, with typically 5 
percent of their quota being available as soon as the contagion sets in, with activation of a further credit line requiring a "quick" review by the IMF. To date no nation has made use of this facility, and during November 2003 they were suspended (IMF 2004), "partly reflecting concerns by eligible countries that a request under this facility would be viewed as a sign of weakness rather than strength” (RBA 2004:4). ${ }^{7}$

These reforms, introduced in an environment of major financial crises, potentially provide an important component of stability. Collectively the reforms are designed to protect the poor, extend prudential safeguards, propel corporate governance, and establish some limited foundation for an ILLR. In principle at least, these changes should increase the flow of information, reduce the extent of hot capital flows, and enhance liquidity during times of crisis and contagion. From an SSA perspective, they specifically address a critical requirement: stability of the global monetary system, and the stable workings of the global circuit of money capital. And in this respect, depending on how they are activated, and whether reform is ongoing, they should reduce the extent of uncertainty and thereby promote some critical SSA functions.

Overall, these changes that are embedding economy within society are a modification of the classic neoliberal perspective toward a moderate ideological and policy outlook on the world. ${ }^{8}$ The IMF has come to recognize the problems of money capital being too dominant in emerging and developing nations, especially short-term debt from overseas denominated in US dollars. These volatile sources of "hot money" can adversely affect the dynamics of long-term investment and need to be moderated. One way to moderate this source of contagion is to have robust prudential controls over capital flows, which some countries have instituted. Another is to have a currency board, which others have begun to use.

There is also a trend away from flexible exchange rates toward managed floats, currencies pegged to a set of rates or a "hard currency," and currency unions. Fixed rates, however, are not generally recommended (see Blinder 1999). The IMF has sought to reduce the potential for crises through better systems of regulation, supervision, accountability, and governance. Then, once the crisis commences, it seeks to provide credit to help prevent the contagion. It provides emergency and immediate credit where fundamental variables are good and certain conditions prevail. The IMF is apparently serious about the adverse social and economic effects of poverty, and how critical it is to alleviate substandard living standards through safety nets, redistributive measures, and even the promotion of civil society (IMF 2000).

Therefore, the IMF is developing an evolving weak-form global central banking function that propels a critical MOR (or SSA) function of financial stability. However, this is true to only a certain degree, because many of the changes have yet to be tested extensively in practice during financial crises, and other policy measures could be implemented in order to propel even further stability to the global monetary system. As discussed in Chapter 10, it is necessary to reduce the global conflict between finance and industry somewhat by the introduction of some combination of Tobin Tax (on mobile capitals), Davidson proposal (to put the onus on current account surplus nations to increase demand), and asset-based reserve requirements (on equities, real estate, etc. adjustable where necessary). Linked to these is the need to create truly global money so as to partially or wholly transcend the US dollar as international money. These policies would be likely to reduce significantly the degree of financial instability and enhance 
system-functions. Hence, while the IMF has moderated its neoliberal perspective to some degree toward an embedded perspective, it certainly could enhance the provision of system-functions to more fully satisfy MOR or SSA conditions (see Davidson 1999).

Overall, we conclude that global financial instability should decline to some extent as a result of the positive reforms within the IMF. For the first time in history this institution is incorporating (quasi) ILLR facilities and poverty relief programs into its essential functions and practices. It should, therefore-in the balance of ferces, if these changes are seriously and successfully implemented-enhance somewhat the development of long wave upswing through the provision of system-functions and a public goods role.

\section{WTO trade regime and the resolution of conflict}

A critical public good is the provision of conflict resolution over trade issues so as to resolve problems of sale and purchase within the circuit. This is especially critical in view of differences in labor practices, environmental concerns, cultural norms, production niches, and policies. Being able to coordinate trade in light of these differences requires the making of agreements-both multilateral and unilateral-to reduce the level of uncertainty, risk, and conflict. ${ }^{9}$ A critical conflict resolution institution within the global circuit is the WTO. The operational dynamics of the WTO are here used as an institutional proxy for the degree of conflict resolution within the trade part of the circuit of social capital.

The WTO attempts to resolve conflict between nations, and indirectly this relates to the conflict between different fractions of global business for a share of the global economic surplus (intra-class conflict). It also relates to class conflict over issues such as labor and health standards (at least potentially). But, more generally, the conflicts that are in need of resolution in the trade regime are multifarious. They represent conflicts over access by different nations and regions to the global system of trade, but they also concern conflicts over environmental, labor, foreign investment, competition, industrial, health, and patent issues that impact on trade. The concern of this section is to examine the trade regime in the context of the main areas of conflict and to use the functioning of the WTO within the circuit as a proxy for whether the current regime is satisfactorily resolving conflict by reducing coordination failures in the system (Keohane 1984; Fairris 1999).

To understand the workings of the current regime it is important to situate it historically. The system that currently operates is a hybrid of the General Agreement on Tariffs and Trade (GATT) arrangements that emerged in 1948 and more recent changes. GATT was initially a series of general agreements among the 23 major industrial nations to try and formulate a workable series of multilateral trade negotiations. This included efforts to reduce mainly industrial tariffs; a code of rules and norms concerning imports and exports; and a periodic round of meetings to promote further debate and priorities. Nine rounds of discussions have emerged from the original GATT process. Four of them were critical. The first, Geneva Round (1947), saw cuts in industrial tariffs of 21 percent. The sixth Kennedy Round (1964-1967), which included 62 nations, cut tariffs by 36 percent. The seventh Tokyo Round (1974-1979) advanced tariff cuts of 30 percent and expanded membership to 90 nations. The critical eighth, Uruguay Round (1987-1994), 
which included 125 nations, saw tariff cuts of 38 percent, and expanded the agenda from industrial products to include agriculture, services, trade aspects of investment, and intellectual property (Yarbrough and Yarbrough 1997; Kreinin 1998).

The Uruguay Round took seven long years to conclude, due to the protracted influence of debt crises and deep recessions. But landmark developments emerged as GATT became integrated into the newly emerging WTO, some developing nations were included in a serious manner in the negotiations for the first time, and a number of important agreements were instituted. The commencement of the WTO in 1995 was the most significant institutional innovation in the trade regime since the GATT agreements of 1948, and potentially could be the most significant element of a new global MOR or SSA. For the first time in history an actual organization advances the interests of free trade, rather than simply an array of ("gentlemen's") agreements such as GATT. The WTO has its headquarters in Geneva, incorporates the GATT principles, institutes its own agreements, has its own grievance resolution procedure, and also an appeal process. As William Lash states:

The WTO dispute resolution mechanism is still based on the old GATT principles of negotiation, conciliation, mediation, and arbitration. If this mechanism is unsuccessful, an impartial panel hears the case and renders a finding. If the measure in question is found to be inconsistent with WTO rules, the offending state has the option of changing the WTO-inconsistent measure or offering trade compensation in the form of lower tariffs or increased market access to the aggrieved nation. In the unlikely event that the parties cannot come to any agreement at this stage, the complaining party may take retaliatory measures equal to the amount of the offending action against the offending nation. This action would have the approval of the WTO. The dispute settlement system of the WTO is intended to provide "security and predictability" to the entire multilateral trading system.

(2000:374)

The Agreements made at the Uruguay Round were, in large measure, to be implemented by developed nations by 2000 and developing or undeveloped nations by 2004 . There were eight main agreements, including the elimination of tariffs on Pharmaceuticals, construction materials, agriculture, paper, furniture, toys, and beer; a large reduction of tariffs on chemicals and electronic items such as semiconductors; and reductions on many other products. A critical change for the South was a 21 percent reduction in subsidies on agricultural exports; and the replacement of nontariff barriers, and then a reduction in tariffs. Export subsidies are prohibited in the WTO, except for regional, environmental, and research and development $(\mathrm{R} \& \mathrm{D})$ areas. There is also a gradual phasing in of services into the WTO process through the General Agreement on Trade in Services (GATS); especially in accounting, engineering, construction, wholesale and retail, legality, computing, finance, education, and health services.

A major development of the Uruguay Round is the inclusion of Trade-Related aspects of Investment Measures (TRIMS), Trade-Related aspects of Intellectual Property (TRIPS), and the general conditions governing production in different countries. For 
instance, the TRIMS Agreement seeks to phase out certain trade-related restrictions on foreign investment, such as local content prescriptions, import-volume limits, and tradebalancing requirements. The TRIPS Agreement seeks to protect copyright, trademarks, industrial designs, patents, and integrated circuit design from improper copying and counterfeiting. In this round, less developed nations had until 2002 (TRIMS) and 2006 (TRIPS) to comply with these agreements, but the progress has been slow (WTO 1995; Samahon 2000).

The WTO was conceived as the formalization of the rule of international law and due process, to provide for a more stable and less conflict-ridden process of free trade to enhance the interests of business and industry at the global level. Without a doubt, the WTO has had considerable success to date in resolving conflicts. As William Lash concludes:

\begin{abstract}
Dispute settlement is what the WTO does best. Trade disputes are brought before the WTO at approximately three times the rate that had typically been handled by the GATT. In the past four years, the United States has been the greatest proponent of this system. Approximately 40 cases have been brought by the United States seeking compliance with trade agreements and market access. The United States has had a good deal of success in this forum, winning a large majority of its cases. U.S. trade advocates have gained market access in areas ranging from agriculture to information technologies. In contrast, the WTO's predecessor, the GATT,...failed to resolve many disputes and lacked credibility as a mechanism for resolving trade disputes.
\end{abstract}

(2000:373)

The balance of opinion among WTO specialists is that this organization has been very successful in promoting the free trade agenda; in particular, in resolving conflict in the global trade economy along market lines. And there is also no doubt that, on balance, it has continued the process of supporting the advanced industrial nations and corporations, especially the United States, while offering a window of hope and some concessions for developing nations (especially those from East and South-East Asia). It is in better shape to tackle problems of trade that impede globalization and corporate profit than any other trade arrangement in the history of capitalism. Perhaps for that reason, it has been at the center of a growing momentum to influence the course of its functioning from a diverse group of vested interests, stakeholders, and nongovernment organizations. Many interests want it to be a forum for their own concerns about free and fair trade. As the New Millennium Round of discussions struggle to take hold the stakes are high and the issues are diverse.

As mentioned, most of the Uruguay Round agreements were supposed to be completed for developed nations in 2000 and those for developing and underdeveloped by 2004. In the meantime, there are many difficulties associated with the whole process of formulating an agenda for the New Millennium Round, and even more difficulties for a successful resolution of the agenda items once they are formulated. The WTO Ministerial meetings at Seattle in December 1999 commenced amid rancor and opposition to free trade and corporate power from a variety of environmentalists, trade 
unions, labor rights activists, and consumer rights campaigners. Some estimates are that there were 40,000 demonstrators at Seattle (Tabb 2000), not to mention the recent demonstrations against the World Trade Forum and similar organizations in many other nations. Many of these groups believe that the "WTO is a forum for trade rights of capital, on terms negotiated by the agencies of governments that represent the interests of capital. No other rights count” (Tabb 2000:8). The more economically literate of these groups or individuals believe that the WTO is not adequately recognizing the existence of substantial negative global externalities associated with certain environmental, labor rights, health, cultural, and consumer issues in the WTO agenda (Neumayer 2000). ${ }^{10} \mathrm{At}$ the same time, new discussions are necessary with the making of resolutions eventually for a new phase of reform within the WTO. Issues such as continuing reform of services, agriculture, competition policy, intellectual property, trade aspects of FDI, internal governance, as well as the role of environmental, health, and labor issues need to be thoroughly discussed and analyzed.

A new (ninth) (Millennium) round of discussions was supposedly commenced in November 2001, based on the Ministerial meetings in Doha (Qatar). However, many agree that "to call it a 'round' of trade negotiations might be stretching the concept of a round” (Bello 2001). Instead, at Doha discussions were started to modify or clarify existing agreements such as antidumping, as well as transparency in investment, competition policy, and government procurement. A deadline for most negotiations to be finalized is set for January 2005 (WTO 2001). However, many disputes are in need of resolution that will make the Doha Round troublesome and time consuming. For instance, many developing nations want concessions over the enforcement of food safety standards and upgrading customs valuation procedures, and the easing of obligations for investor protection and subsidies. They are also concerned that the Uruguay Round did not deliver on agriculture and textiles, since the European Union remains highly protectionist and the United States has not sufficiently liberalized textiles and agriculture. The United States, the European Union, and Japan want a forum on labor rights and extra monitoring on environmental issues, since developing nations gain an unfair cost advantage and implicit protection in these areas. The developing nations counter that these initiatives on labor rights and the environment introduce protection through the back door. Also, the United States and the European Union have differences about the scope of the new round of discussions. The United States want a narrow approach centering on further reductions in industrial tariffs and reform of services and agriculture, while the European Union seeks scope to include investment and competition policy in the agenda.

Three different approaches have emerged concerning the desired nature of the agenda to be discussed at the New Millennium meetings. These include a minimalist (Ferris wheel or conservative) program to concentrate on issues already agreed for further development, a liberal (bicycle) program to include a few new critical issues (keeping the reform program going in an active fashion), and a more radical (helicopter) program to extend the scope considerably.

The Ferris wheel ${ }^{11}$ (minimalist) approach is proposed by the more conservative, free trade elements of academia, government and business, well illustrated by the Winter 2000 issue of the Cato Journal (2000; see also, for example, Lash 2000). They see the success of the WTO-covering 85 percent of the population and 95 percent of the trade of the world - as being due mainly to its narrow focus and modest proposals. There are four 
planks in their agenda. The first is an agriculture agenda concentrating on removing farm export and domestic producer subsidies and greater export market access for developing nations in particular. They want sanitary and phytosanitary measures to be strictly limited to food safety and animal and plant health based on "available scientific evidence." Agriculture is now in the mainstream of reform and extending current developments, along with reduced US intransigence, is needed on this front.

Second, in the Ferris wheel approach, further liberalization is said to be needed in textiles and clothing. Third, it is consistent with the Uruguay Round agreements to start comprehensive liberalization of services (GATS), including telecommunications, electronics, health, air cargo, legality, finance, and energy. Special attention should be given to the temporary entry of foreign technical and managerial personnel. And fourth, it places emphasis on unilateral initiatives taking priority, with multilateral reforms (WTO) having a secondary priority so as to "lock in" or "insulate" free trade at the national level in the face of changing governments, policies, and priorities. Regional trade agreements should have less priority. A typical Ferris wheel advocate such as William Niskanen (2000:461) believes that "intellectual property, the aborted agreement on investment, and...anti-dumping rules...would unduly complicate the next round,” while international rules on labor, environment, and competition "should be avoided at all costs."

The bicycle (liberal) program seeks to extend the priorities to include, or make further advance on, issues such as competition policy, trade aspects of investment, democratic reform of the WTO, and concern for developing nations. Competition policy is seen to be important in order to enhance antitrust laws at the global level by controlling cartels, cross-boarder mergers and acquisitions, especially US monopolies having unfair power in US-EU trade. There is concern to advance further agreement on trade aspects of foreign investment (see Ethier 2001). There is a concern to enhance democratic reform within the WTO to make hearings public, allow nongovernment organizations the right to testify, and expand the expertise brought to WTO hearings and appeals beyond legal issues to the specifics being addressed (see Schott 2000). And there is a need to increase the power of developing nations by introducing a common fund to finance some of their legal costs to counter the unfair advantages developed nations have. It is also important to extend the preferential treatment given to developing nations in trade, and for the poorest nations to have an extension of their free use of patents in some areas (which has now passed a resolution). These changes may expand and deepen the global circuit into new areas and sectors.

The helicopter program is more radical or extensive, including some of the bicycle (and perhaps Ferris wheel) proposals but going beyond them to include the environment, health, culture, and (possibly) labor rights (see Herman 1999; Neumayer 2000a). There is a widespread perception, for instance, that the WTO isn't serious about protecting the environment, and that, in more technical economic language, it hasn't adequately addressed social welfare questions such as internalizing negative transborder externalities (e.g. pollution, health). Some even believe that the "WTO is a tool of the countermobilization by transnational capital against social protections” (McMichael 2000:473). The failure to internalize externalities through excessive free trade may lead to an inefficient allocation of resources. Despite the mention of "environmental protection and sustainable development” in the WTO’s preamble (Miller and Croston 1999), and some lip service being given to environmental concerns, the weight of evidence seems to 
support these allegations. Indeed, the Ferris wheel proposal argues that free trade has always been at the apex of the WTO's agenda, and that it was never meant to. and should not seriously consider "other issues." However, a close analysis of some of the cases that have come before the WTO dispute settlement process, such as the dolphin-tuna and shrimp-turtle disputes, reveal that, in purely operational terms, the WTO needs to at least come to terms with ecological concerns when they impact on trade.

For instance, the 1991 Dolphin-Tuna dispute involved the United States imposing an embargo on imports of tuna caught with purse reine and driftnet fishing methods (which result in many dolphins being killed). The WTO rejected the use of environmental rules on production methods beyond national boundaries, arguing that national laws cannot be extended to other nations. In another case, the 1998 Shrimp-Turtle dispute, the United States imposed a ban on the sale of shrimp caught without special turtle excluder devices (TEDs) on boats to protect five species of endangered sea turtles. Sea turtles have been designated an endangered species in various multilateral agreements, and the United States made the use of TEDs compulsory for catching shrimp in the 1990 Endangered Species Act. Thailand, India, Pakistan, and Malaysia challenged the ban as an unfair trade barrier, and the WTO ruled in their favor. Yet the appellant body in the shrimpturtle case did not uphold the dolphin-tuna ruling against extraterritorial use of national laws for environmentally destructive fishing methods. Instead, it ruled that a nation would need to engage in bilateral or multilateral treaties with shrimp harvesting nations to insist on the use of TEDs, and only after that failed could a nation introduce unilateral measures (Neumayer 2000). ${ }^{12}$

Thus, the appellate body "move[d] away from a very restrictive, trade-centred interpretation of GATT law and towards a position in which trade and environmental objectives are more carefully weighed against one another” (Liebig 1999:84). However, these apparent inconsistencies in the WTO rulings, and the general impression that the WTO does not sufficiently recognize the need to internalize global externalities, requires that the Qatar Round of discussions resolve some of these environmental anomalies. This would help to differentiate between a "real" environmental concern and policies simply designed to inhibit trade competition, and it would also reduce the extent of the NGO's strident attacks on the organization. Possibly a World Environment Organization is necessary to work in consultation with the WTO, dealing with less trade-oriented environmental issues.

The Cancun Ministerial Meeting of September 2003 failed to sustain real advances in agreements, and the environment was entirely sidelined in favor of agricultural and investment reform (Gnath 2004). The sidelining of the environment has continued ever since. Indeed, any successes that were obtained in discussions in Geneva in July 2004 were made entirely by taking a minimalist approach (not dissimilar to the Ferris wheel program with the emphasis being given to developing countries vis-à-vis agricultural subsides and related themes). As the United Nations University states:

[F]or the first time, member governments have not only agreed to substantial reductions in trade distorting domestic support for agriculture, they have also agreed to abolish all forms of agricultural export subsides. Also in the area of agriculture, there has been a significant breakthrough in dealing with the impediments to cotton trade, offering new potential 
opportunities for cotton farmers in West Africa and throughout the developed world.

Hence, recently there appears to have been some WTO advance especially in reform of agriculture, deepening the commitment to "the needs and interests of developing and least-developed countries," and the call for reductions and phasing out of "tradedistorting domestic support” (such as subsides) (WTO 2004:2, 4). However, it is too early to say whether this is likely to impact upon programs of action or whether it is merely a form of rhetoric to instill confidence in the light of recent setbacks and conflicts. As the World Bank (2004:5) notes, "the road ahead is long and full of obstacles," while many details need to be ironed out by the time of the next WTO Ministerial Meeting in December 2005 in Hong Kong. A trade regime that extends global growth and development is thus not likely in the near future if the pattern of the past several years is any indication.

Pending further advance, it is likely to be very difficult to succeed in a program of action for the "Doha Development Round" in the light of demonstrations over the past few years, the seemingly intractable disagreements between developing and developed nations, the widely divergent opinions on the scope of the new round of discussions between the United States and the European Union, and the recent redirection of attention to matters of global terrorism. Once a Doha Round Agenda is set more fully, however, it may be years before any substantive agreements are finalized, not to mention activated. Thus, an improvement that reduces conflict and improves the institutional functions of the global SSA within the circuit faces a difficult and time-consuming future. ${ }^{13}$ Institutions linked to the promotion of conflict resolution in the area of trade have thus not become activated sufficiently at this stage to promote the reproduction of the global circuit, in an ongoing fashion, for long wave upswing.

\section{Conclusion}

The purpose of this chapter has been to assess the degree to which a new global mode of regulation or social structure of accumulation is being developed within the global circuit so as to contribute to long wave upswing in the world economy. We used three proxies for the promotion of global system-functions within the circuit. For productivity and demand, the prevailing systems of production and distribution were examined. For financial stability, the IMF was used. And for conflict resolution, the WTO was used. The main conclusion of this chapter is that the current configuration of institutions and institutional spheres-taken as a whole-does not support long wave upswing. The regime of production-distribution-the most important cluster of institutions and technology within the MOR - is of insufficient productivity and demand, and hence failing to support global system-functions. While the changes ongoing in the IMF during the late 1990s are likely to promote the global system-function of financial stability, the motion of the WTO does not support the expansion of conflict resolution to an even moderate degree at present, although some optimistic trends are in the early stages of 
development. In the current institutional environment it may be difficult to propel sustained agreement and activation of trade reform.

Overall, then, a suitable global MOR or SSA that encompasses the regime of accumulation and institutional clusters is not likely to be currently in operation to support long wave upswing in the world economy. If the pattern of wave and cycle over the past 50 years is any indication, the first decade of the twenty-first century will likely follow through from the recession of the early 2000s to likely (short-cycle) recovery and boom of the middle to late years of the first decade, through to a downward trend during the beginning of the second decade. The next real test of the existence and potentiality of long wave upswing may well be the extent of speculative bubbles in the high boom of the cycle (during the last few years of the first decade of the 2000s), and the extent of recession (during the first few years of the second decade).$^{14}$ It is necessary to scrutinize the nature of the institutional-technological changes emerging within the global circuit in an ongoing fashion over at least the next decade to ascertain the extent of MOR or SSA development.

\section{Notes}

1 An earlier version of this chapter was presented at the Allied Social Science Associations meetings of the Association for Social Economics, New Orleans, January 5, 2001. Session title: "Institutional Change and International Growth.” I am indebted to the three anonymous referees, and Elba K.Brown-Collier, John Davis, and Libby Assassi. The usual caveat applies. A much earlier version of this chapter was published in the Review of International Political Economy, Volume 10, Number 3, August 2003, pp. 481-519.1 wish also to thank some of my graduate students for various comments on this chapter.

2 Casey (1999:155), for instance, concludes that “these new 'designer' cultural practices serve as processes of regulation, discipline, and control of employee subject selves"; while Parker's (1999:139) research in the United States reveals that "companies pursuing lean production are not particularly interested in helping their union members to develop advanced technical skills. What they do want is a more flexible workforce, but management flexibility is decreased when worker skill translates into power and resistance to management.” A similar conclusion is made by Laurie Graham (1994).

3 The (most successful) Eastern Archetypes of the flexible system are all Japanese companies, such as Toyota and Kawasaki Heavy Engineering. Successful followers include Motorola, Hewlett-Packard, and Ford (leading Western followers). Moderately successful followers include a large Indian electrical engineering firm (Crompton Greaves); Ford's operations in Mexico; and three Indonesian auto manufacturers (see Harriss 1995). And lastly, weakly successful followers include many "LDC implementers" where,

adoption is confined to individual subprocesses and very limited interaction with individual [regimes] or that of failures" (p. 61). "Differences in the adoption of this system may be a product of two processes. First, those on the low end of adoption are simply late starters. And secondly, different firms may be capable of different degrees of "deep systemic utilization of [Japanese managerial techniques].

(Harris 1995:61, 63) 


\section{For instance, certain firms may be constrained by internal factors such as bad communication channels in the firm, poor management training, lack of staff on-the-job training; or by external factors like unsuitable infrastructure (roads), a poor level of education of the workforce, and problematic government policy (Kaplinsky 1995:63).}

4 Productivity may be a good general view of the potential for sharing the benefits of production for profit and/or wages. But it must be recognized that this is not always the case. For instance, it may be possible to have considerable productivity with a relatively high level of competition, yet the high competition may inhibit sufficient profit. This is part of the argument of Veblen (1904) and Brenner (1999).

5 It may well be, as Belussi (2000:36) recognizes, that the FSP is more developed in Japan, Germany, and Italy than in many other nations (e.g. the United States). The key to long upswing may be the success of the Schumpeterian firm that promotes tacit knowledge, supply chains, networks of relationships and processes, long and complex value chains, and technological and product variety (see Gottardi 2000:14-17). If the flexible system of production is the most feasible production-distribution regime for the future (instead of, say, neo-Taylorism) then this will be a challenge to the dominance of the neoliberal Washington Consensus to some degree. The flexible system clearly represents a progressive form of capitalism in which labor is exploited in a more embedded corporate environment.

6 Space precludes a detailed discussion of Minsky’s financial instability hypothesis (FIH), which helps explain the boom, instability and crash of the 1980s in the West as well as the moderately similar experience of some nations in Asia during the 1990s. The similarities of the West and Asia, as they relate to the FIH are (a) financial deregulation reduced the prudential functioning and increased the potential risks in the system; (b) endogenous money and credit led to an (over)expansion of traditional and (especially) nontraditional sources of credit and finance; (c) relatively unproductive activities in the commercial property market and stockmarket created speculative bubbles, which then burst; and (d) the euphoria and overaccumulation, in the light of eventual costs and difficulties, led to the highpoints which eventually underwent a downward spiral. In the late 1990s and 2000 in the West, especially the United States, a similar process of euphoria and overexpansion seems to be happening, which is broadly in accord with the FIH (see O'Hara 2001b).

7 These two new facilities, SRF and CCL, became part of of six credit facilities that the IMF made available to member nations. The other four include: (a) traditional standbys, (b) the Extended Fund Facility (introduced in 1975 for longer-term BOP problems), (c) the Poverty Reduction and Growth Facility (introduced in 2000 for low interest loans to low-income members), and (d) the Compensatory and Contingency Financing Facility (lowconditionality loans introduced in the 1960s for nations experiencing temporary or exogenous problems with exports, import costs interest rates, etc) (see Williamson 2000). Some critics have suggested merging the SRF and CCL into a "crisis facility" so that having a separate CCL facility does not promote further crisis and contagion by nations being classified as "crisis and contagion driven" (Williamson 2000). As might be expected, free banking scholars have critiqued these facilities as propelling crisis and contagion (e.g. Hanke 2000).

8. Michal Aglietta (1998) explains why the neoliberal policy apparatus is not sustainable. He believes that the main problem with neoliberalism relates to a critical contradiction of individualism. As he said: "The positive side [of individualism] consists of its emancipation from the shackles of a system of social allegiance, from personal subordination, [and] loyalty... The negative aspect of individualism...is that membership of society, in other words the legitimization of individual acts, has to be constantly reclaimed. Taken to 
extremes, individualist demands tend to dissolve the social fabric from which such demands derive their validity" (Aglietta 1998:70).

9 We saw above that the post-Fordist systems of production-as well as institutions such as neoliberalism - have contributed to a reduction in the degree of conflict between capital and labor, mainly by reducing the dominance that labor had during the late 1960s and the early 1970s. Contradictions then led to a decline in the sphere of demand Some might argue also that the FSP has reduced conflict somewhat by including labor in the scheme of things to a minimal degree.

10 It is true, as John H.Dunning (2000:475) recognizes, that these various NGOs failed to offer a real alternative to capitalism, and did not sufficiently recognize that their various objectives are frequently contradictory. Also, as he emphasizes, a critical agenda for the world economy is the generation and maintenance of a fund of social capital of trust, sympathy, and relationships.

11 To be more specific, the "Ferris wheel" program implies the need to "go round and round" without including any new policies such as those concerning competition policy or the environment. The "bicycle" program is so named because it assumes the need to advance into relatively new territory for the WTO. And the "helicopter" program is so named because this program seeks to go beyond the conservative and liberal policies to a higher level of the environment, health, and possibly labor rights.

12 At a more general level, the arguments of the environmentalists against the WTO are critical. This is especially true when it is recognized that the value of the Earth's ecosystem services, "including such...processes as soil formation, nutrient cycling and habitat maintenance for biodiversity" is worth around "\$33 trillion annually, well in excess of global GDP” (Ken Conca 2000:485).

13 Some authors would go further. As Chakravarthi Raghavan (2000:503) believes, unless certain changes are instigated in the WTO to embed economy within society, "the late twentieth-century version of 'globalization' and neoliberalism may meet the same fate as the nineteenth-century globalization and liberal (laissez faire) order, spawning social conflicts and breakdowns.” It would appear that a new set of trade agreements will need to be written that go beyond the raw neoliberal policies of the Washington Consensus in a way that embeds economy within society to a greater degree (see Watchel 2000).

14 However, to further comprehend the potential for long wave upswing we must look to the formation of national institutions concerning the financial system, industrial relations, the state, and the family. See, for instance, O’Hara (2000a, b), Hossein-Zadeh and Gabb (2000), O’Hara (1999:1054-1068), Lippit (1997), O’Hara (1995), and Kotz et al. (1994). Indeed, it is likely that multiple SSAs are necessary for the global political economy, not only linked to global production-money-trade (as discussed in this chapter) but also the hegemonic economic-military-foreign affairs system (see O’Hara 2002a). Hence, whatever conclusions are made in relation to this current chapter, they may potentially be overshadowed by changes in some of the other potential SSAs or institutional forms.

\section{References}

Aglietta, Michel. (1998) "Capitalism at the Turn of the Century: Regulation Theory and the Challenge of Social Change,” New Left Review, Number 232, pp. 41-90.

Aglietta, Michel. (2001) The International Monetary Fund and the International Financial Architecture, Working Paper of the Centres d'Etudes Perspectives et d'Informations Internationales (CEPII), Paris.

Allen, Roy E. (ed.) (2004) The Political Economy of Financial Crises, 2 vols, Cheltenham, UK and Northampton, MA: Edward Elgar. 
Barnett, C. (2000) “E-Lagacy: The IP Systems Challenge,” Journal of General Management, Volume 25, Number 10, pp. 1-16.

Basle Committee. (1997) Core Principles, Basle: BCBS.

Bello, Walden. (2001) “The Meaning of Doha,” Trade Observatory: WTO Watch, Volume 16, November, http://www.tradeobservatory.org/ (accessed November 15, 2001).

Belussi, Fiorenza. (2000) "Towards the Post-Fordist Economy: Emerging Organizational Models,” International Journal of Technology Management Volume 20, Numbers 1 and 2, pp. 20-43.

Bettio, Francesca and Samuel Rosenberg. (1999) "Labour Markets and Flexibility in the 1990s: The Europe-USA Opposition Reversed,” International Review of Applied Economics, Volume 13, Number 3, pp. 269-279.

Blinder, Alan S. (1999) “Eight Steps to a New Financial Order,” Foreign Affairs, Volume 78, Number 5, pp. 50-63.

Brenner, Robert. (1999). “Competition and Class: A Reply to Foster and McNally,” Monthly Review, Volume 51, Number 7, pp. 2444.

Camdessus, Michael. (1999) "Second Generation Reforms: Reflections and New Challenges," Opening Remarks to the IMF Conference on Second Generation Reforms, November 8, www.inf.org/external/np/speeches/1999/110899.htm (accessed June 1, 2001).

Cantwell, J. and G.D.Santangelo. (2000) "Capitalism, Profits and Innovation in the New TechnoEconomic Paradigm,” Journal of Evolutionary Economics, Volume 10, pp. 131-158.

Cartapanis, Andre and Michel Herland. (2004) "The Reconstruction of the International Financial System: Keynes’ Revenge,” in Roy E.Allen (ed.), The Political Economy of Financial Crises, Volume II, Cheltenham, UK and Northampton, MA: Edward Elgar, pp. 500-526.

Casey, Catherine. (1999) "Come, Join our Family: Discipline and Integration in Corporate Organizational Culture,” Human Relations, Volume 52, Number 2, pp. 155-178. Cato Journal (2000) “Special Issue on the World Trade Organisation,” Volume 19, Number 8, pp. 1-228.

Cohen, Benjamin J. (2001) "Electronic Money: New Day or False Dawn,” Review of International Political Economy, Volume 8, Number 2, pp. 197-225.

Conca, Ken. (2000) "The WTO and the Undermining of Global Environmental Governance,” Review of International Political Economy, Volume 7, Number 3, pp. 484-494.

Cooper, Richard. (1999) “A Tour of International Financial Reform,” Challenge, Volume 42, Number 4, pp. 5-28.

Cooper, Richard (2002) “Chapter 11 for Countries?” Foreign Affairs, Volume 81, Number 4, pp. 90-113.

Cooper, Russel and Gary Madden, (eds) (2004) Frontiers of Broadband, Electronic and Mobile Commerce, Heidelberg: Physica-Verlag.

Dassbach, Carl H.A. (1999) "Lean Production in North America: Myth and Reality,” in Riccardo Bellofiore (ed.), Global Money, Capital Restructuring and the Changing Patterns of Labour, Cheltenham, UK and Northampton, MA: Edward Elgar, pp. 111-123.

Davidson, Paul. (1999) If Markets are Efficient, Why Have there been so Many International Financial Market Crises since the 1970s?, paper presented at the What Global Economic Crisis conference, University of Cambridge, September.

Davidson, Paul. (2000) "Monetary Policy in the Twenty-First Century in the Light of the Debate between Chartalism and Monetarism," in Jeff E.Biddle, John B.Davis, and Steven G.Medema (eds), Economics Broadly Considered: Essays in Honor of Warren J.Samuels, London and New York: Routledge, pp. 336-349.

Dunning, John H. (2000) “The Future of the WTO: A Social-Relational Challenge,” Review of International Political Economy, Volume 7, Number 3, pp. 475-483.

Eichengreen, Barry. (2000) "The Global Gamble on Financial Liberalisation: Reflections on Capital Mobility, National Autonomy, and Social Justice,” International Affairs, Volume 22, pp. 205-226.

Ethier, Wilfred J. (2001) “Theoretical Problems in Negotiating Trade Liberalization,” European Journal of Political Economy, Volume 17, pp. 209-232. 
Fairris, David. (1999) “Social Structures of Accumulation,” in Phillip Anthony O’Hara (ed.), Encyclopedia of Political Economy, London and New York: Routledge, Volume 2, pp. 10651068.

Fischer, Stanley. (1999) "Reforming the International Financial System,” The Economic Journal, Volume 109, Number 459, pp. F557-F576.

Gnath, Katharina. (2004) The WTO and the Environment:...More Words Than Deeds, Amsterdam: Weltpolitik.

Gore, Charles. (2000) "The Rise and Fall of the Washington Consensus as a Paradigm for Developing Countries,” World Development, Volume 28, Number 5, pp. 789-804.

Gottardi, Giorgi. (2000) "Presentation: How Should Technology be Managed in the Post-Fordist Era,” International Journal of Technology Management, Volume 20, Numbers 1and 2, pp. 118.

Graham, Laurie. (1994) "How does the Japanese Model Transfer to the United States? A View from the Line,” in Tony Elger and Chris Smith (eds), Global Japanization? The Transnational Transformation of the Labour Process, London and New York: Routledge.

Hanke, Steve H. (2000) “Money Reform,” The International Economy, Volume 14, Number 5, pp. 29-31.

Harriss, John. (1995) “Japanization: Context and Culture in the Indonesian Automotive Industry,” World Development, Volume 23, Number 1, pp. 52-67.

Herman, Lawrence L. (1999) “The WTO in the 21st Century,” Ivey Business Journal, July/August, pp. 51-58.

Hossein-Zadeh, Ismael and Anthony Gabb. (2000) "Making Sense of the Current Expansion of the U.S. economy: A Long Wave Approach and a Critique,” Review of Radical Political Economics, Volume 32, Number 3, pp. 388-397.

IMF (International Monetary Fund). (1998a) "IMF Financing helps Members Pursue Sound Policies,” IMF Survey Supplement, Volume 27, September, pp. 4-5.

IMF. (1998b) Toward a Framework for Financial Stability, Washington, DC: IMF.

IMF. (1999a) "Strengthening the SDDS and Improving Access to Debt" and "Surveillance helps Members Identify and Correct Problems Wuickly,” IMF Survey Supplement, Volume 28, September, pp. 8-10.

IMF. (1999b) “Camdessus Discusses Prospects for Globalization, Need to Fight 'Patent Injustice' of World Poverty,” IMF Survey, Volume 28, Number 23, pp. 385-388.

IMF. (2000) "Summit Meetings: Leaders Call for Cooperative Effort to Reduce Debt and Poverty, Promote Growth, Liberalize Trade,” IMF Survey, Volume 29, Number 15, pp. 241-245.

IMF. (2003) Effects of Financial Globalization on Developing Countries: Some Empirical Evidence. (Authors: Eswar Prasad, Kenneth Rogoff, Shang-Jin Wei, and M.Ayhan Kose.) March, Geneva: International Monetary Fund.

IMF. (2004) The IMF's Contingent Credit Lines (CCL), Geneva: International Monetary Fund, http://www.irnf.org/external/np/exr/facts/ccl.htm

Jessop, Bob. (ed.) (2001) Regulation Theory and the Crises of Capitalism, 5 vols, Cheltenham, UK: Edward Elgar.

Kadmos, George Anthony and Phillip Anthony O’Hara. (2000) “The Taxes-Drive-Money and Employer of Last Resort Approach to Government Policy,” Journal of Economic and Social Policy, Volume 5, pp. 1-22.

Kadmos, George Anthony and Phillip Anthony O’Hara. (2001) “The International Monetary Fund: Functions, Financial Crises and Future Relevance,” in B.N.Ghosh (ed.), Contemporary Developments in Development Economics, London and New York: Routledge, pp. 154-186.

Kaplinsky, R. (1995) “The Spread of Japanese Management Techniques to Developing Countries,” World Development, Volume 23, Number 1, pp. 57-71.

Kenney, M. and J.Curry. (1999) "E-Commerce: Implications for Firm Strategy and Industry Confideration,” Industry and Innovation, Volume 6, Number 2, pp. 131-151. 
Keohane, Robert O. (1984) After Hegemony: Cooperation and Discord in the World Political Economy, Princeton, NJ: Princeton University Press.

Kotz, D.M., McDonough, T., and Reich, M. (eds) (1994) Social Structures of Accumulation: The Political Economy of Growth and Crisis, Cambridge, UK and New York: Cambridge University Press.

Kreinin, Mordechai E. (1998) International Economics: A Policy Approach: Euro Update, London and New York: The Dryden Press.

Lash, William III. (2000) “The Limited but Important Role of the WTO,” Cato Journal, Volume 19, Number 3, pp. 371-377.

Liebig, Klaus. (1999) “The WTO and the Trade-Environment Conflict,” Intereconomics, Volume 34, Number 2, pp. 12-21.

Lipietz, Alain. (1997) “The Post-Fordist World: Labor Relations, International Hierarchy and Global Ecology,” Review of International Political Economy, Volume 4, Number 1, Spring, pp. $1-41$.

Lippit, V. (1997) “The Reconstruction of a Social Structure of Accumulation in the United States,” Review of Radical Political Economics, Volume 29, Number 3, pp. 11-21.

Little, Jane Snedden and Giovanni P.Olivei. (1999) "Why the Interest in Reforming the International Monetary System,” New England Economic Review, September/October, pp. 5384.

McMichael, Philip. (2000) "Sleepless since Seattle: What is the WTO About?,” Review of International Political Economy, Volume 7, Number 3, pp. 466-474.

Madden, Gary, Scott Savage, and Grant Coble-Neal. (2000) "Internet Adoption and Use," Prometheus, Volume 18, Number 2, pp. 161-173.

Maddison, Angus. (1991) Dynamic Forces in Capitalist Development: A Long-Run Comparative Perspective, Oxford and New York: Oxford University Press.

Marx, Karl. (1894) Capital Volume 3, Harmondsworth: Penguin Books, 1976.

Miller, Carol J. and Croston, Jennifer L. (1999) "WTO Scrutiny v. Environmental Objectives: Assessment of the International Dolphin Conservation Program Act,” American Business Law Journal, Volume 37, Number 1, pp. 73-125.

Neumayer, Eric. (2000) "Trade and the Environment: A Critical Assessment and Some Suggestions for Reconciliation,” Journal of Environment and Development, Volume 9, Number 2, pp. 138159.

Nilsson, Eric A. (1999) “Trends in Compensation for Production Workers: 1948-1995,” Review of Radical Political Economics, Volume 31, Number 4, pp. 133-163.

Niskanen, William A. (2000) “Building on the WTO’s Success,” Cato Journal, Volume 19, Number 3, pp. 459-461.

O’Hara, Phillip Anthony. (1995) “Household Labor, the Family, and Macroeconomic Instability in the United States: 1940s-1990s,” Review of Social Economy, Volume 53, Number 1, pp. 89120.

O’Hara, Phillip Anthony, (ed.) (1999) Encyclopedia of Political Economy, London and New York: Routledge, 2 vols, Paper edition 2001.

O’Hara, Phillip Anthony. (2000a) “A New Social Structure of Accumulation or the Emerging Global Crises of Capitalism?” in Chapter 14 of Phillip Anthony O’Hara, Marx Veblen and Contemporary Institutional Political Economy: Principles and Unstable Dynamics of Capitalism, Cheltenham, UK and Northampton, MA: Edward Elgar, pp. 266-291.

O’Hara, Phillip Anthony. (2000b) "Money and Credit in Marx’s Political Economy and Contemporary Capitalism,” History of Economics Review, Number 32, pp. 83-95.

O’Hara, Phillip Anthony. (2001a) “Globalisation of Money, Trade and Production: Performance, Problems and Future Prospects for the World Economy," in Kym Thorne and Geoff Turner (eds), Global Business Regulation: Some Research Perspectives, Sydney: Prentice Hall, pp. 7897. 
O’Hara, Phillip Anthony. (2001b) “Regime of Accumulation,” in R.J.Barry Jones (ed.), The Routledge Encyclopedia of International Political Economy, London and New York: Routledge.

O’Hara, Phillip Anthony. (2002) “A New Financial Social Structure of Accumulation for Long Wave Upswing in the United States?” Review of Radical Political Economics, Volume 34, Number 3, pp. 295-301.

O’Hara, Phillip Anthony. (2003) "Deep Recession and Financial Instability or a New Long Wave of Economic Growth for US Capitalism? A Regulation School Approach,” Review of Radical Political Economics, Volume 35, Number 1, Winter, pp. 18-43.

Palloix, Christian. (1977) “The Self Expansion of Capital on a World Scale,” Review of Radical Political Economics, Volume 9, Number 2, Summer, pp. 1-28.

Papadakis, M. (2000) “Technology in the Globalization of the USA,” in T.L.Brewer and G.Boyd (eds), Globalizing America: The USA in World Integration, Cheltenham, UK: Edward Elgar, pp. 134-153.

Parker, Mike. (1999) “Management-by-Stress and Skilled Work: the US Case,” in Riccardo Bellofiore (ed.), Global Money, Capital Restructuring and the Changing Patterns of Labour, Cheltenham, UK and Northampton, MA: Edward Elgar, pp. 125-140.

Perez, C. (1985) "Microelectronics, Long Waves and World Structural Change: New Perspectives for Developing Countries,” World Development, Volume 13, Number 3, pp. 441-463.

Pietrykowski, Bruce. (1999) "Beyond the Fordist/post-Fordist Dichotomy: Working through The Second Industrial Divider,” Review of Social Economy, Volume 57, Number 2, pp. 177-198.

Pini, Paoli. (1995) "Economic Growth, Technological Change and Employment: Empirical Evidence for a Cumulative Growth Model with External Causation for Nine OECD Countries: 1960-1990," Structural Change and Economic Dynamics, Volume 6, pp. 185-213.

Polanyi, Karl. (1944) The Great Transformation, New York: Rinehart.

Raghavan, Chakravarthi. (2000) “After Seattle, World Trade System Faces Uncertain Future,” Review of International Political Economy, Volume 7, Number 3, pp. 495-504.

RBA (Reserve Bank of Australia). (2004) "Recent Developments in IMF Financing Activities," Reserve Bank of Australia Bulletin, June, pp. 1-8.

Samahon, Tuan N. (2000) "TRIPS Copyright Dispute Settlement after the Transition and Moratorium: Nonviolation and Situation Complaints against Developing Countries," Law and Policy in International Business, Volume 31, Number 3, pp. 1051-1075.

Schott, Jeffrey J. (2000) “Prospects for New WTO Trade Negotiations” Cato Journal, Volume 19, Number 3, pp. 379-383.

Spotton Visano, Brenda. (2003) “Financial Crises, Crashes and Speculative Bubbles,” in Phillip Anthony O’Hara (ed.), Global Political Economy and the Wealth of Nations: Performance, Institutions, Problems and Policies, London and New York: Routledge.

Stiglitz, Joseph. (1999) “Quis Custodiet Ipsos Custodes?” Challenge, Volume 42, Number 6, pp. 26-67.

Tabb, William K. (2000) “The World Trade Organization? Stop World Take Over,” Monthly Review, Volume 51, Number 8, pp. 1-12.

Tomaney, John. (1994) “A New Paradigm of Work Organization and Technology?,” in Ash Amin (ed.), Post-Fordism: A Reader, Oxford: Blackwell Publishers, pp. 157-194.

Tylecote, Andrew. (1992) The Long Wave in the World Economy. London and New York: Routledge.

United Nations University. (2004) Overview of the WTO: A Multimedia Training Package. United Nations,

van Ark, Bart, Ewout Frankema, and Hedwig Duteweerd. (2004) Productivity and Employment Growth; An Empirical Review of Long and Medium Run Evidence. Research Memorandum GD71, Groningen: Greningen Growth and Development Centre.

Veblen, Thorstein. (1904) The Theory of Business Enterprise. New York: Charles Scribners Sons. (Reprinted by Augustus M.Kelley, 1975.) 
Wachtel, Howard M. (2000) "World Trade Order and the Beginning of the Decline of the Washington Consensus,” International Politics and Society, Volume 3, pp. 247-253.

Weisskopf, Thomas E., Samuel Bowles, and David M.Gordon. (1985) "Two Views of Capitalist Stagnation: Underconsumption and Challenges to Capitalist Control,” Science and Society, Volume XLIX, Number 3, Fall, pp. 259-286.

Williamson, John. (2000) “The Role of the IMF: A Guide to the Reports,” International Economics Policy Briefs No 00-05, Institute for International Economics, p. 24.

Wolfson, Martin. (1994) “The Financial System and the Social Structures of Accumulation,” in David M.Katz, Terrence McDonough, and Michael Reich (eds) Social Structures of Accumulation: The Political Economy of Growth and Crisis, Cambridge, UK: Cambridge University Press, pp. 133-145.

Woods, Ngaire. (2000) "The Challenge of Good Governance for the IMF and the World Bank Themselves,” World Development, Volume 28, Number 5, pp. 823-841.

World Bank. (2004) Global Economic Prospects 2004: Realizing the Development Promise of the Doha Agenda, http://www.worldbank.org/prospects/gep2004/toc.htm

WTO (World Trade Organization). (1995) Legal Texts: The WTO Agreements. http://www.wto.org/english/docs_e/legal_e/ursum_e.htm

WTO. (2001) The Doha Declaration Explained. Geneva, http://www.wto.org/

WTO. (2004) Doha Work Program: Decision Adopted by the General Council on August 1, 2004. www.wto.org/

Wray, L.R. (1998) Understanding Modern Money: the Key to Full Employment and Price Stability, Aldershot, UK and Northampton, MA: Edward Elgar.

Yarbrough, Beth V. and Yarbrough, Robert M. (1997) The World Economy: Trade and Finance, Fourth Edition, London and New York: The Dryden Press.

Yeung, Henry Wai-chuung. (1998) Transnational Corporations and Business Networks, London and New York: Routledge. 


\section{6 \\ A global unipolar, “antiterrorist” social structure of accumulation?}

\section{Introduction}

This chapter examines the fourth part of the contemporary Global System of Power and Accumulation: terrorism and the unipolar/unilateral trend of military relations. During the 1950s and the 1960s, the United States exerted financial, commercial, and production dominance in the world (Wallerstein 1983). This led to the generation of US hegemony (and a military balance with the USSR), which promoted stability and leadership for the (Western) world for 2 or 3 decades. Samuel Bowles et al. (1992) and others have seen this system of Pax Americana as one of the postwar social structures of accumulation (SSAs) that provided a foundation for stable growth and development. US hegemony declined in the 1970s as it was defeated in Vietnam, lost a productivity edge to Europe and Japan, and underwent domestic challenges as well. While hegemony promoted national and regional growth and accumulation, the loss of hegemony during the 1970s and 1980s had a negative influence on socioeconomic performance of the advanced capitalist economies with the decline in this SSA.

However, with the advent of Reagan's starwars program, the first Iraqi War in the early 1990s, decline in Soviet/Russian power, and the more recent unilateralism trend, many have raised the question of a revival of US hegemony, and whether this may promote performance through a new SSA. However, it is also possible that attempts to renew hegemony may actually promote more conflict and instability in the world, leading to a disruption of socioeconomic relations and a heightening of uncertainty. The latter would be likely to lead to less global and regional investment and consumption, especially in areas where such conflict has risen. This chapter examines the dominant contemporary issue of terrorism in association with the US unilateralist trend and the attempt at hegemonic revival.

Specifically, we examine the extent to which current developments in the theatre of developing US unilateralism, first strike capability, "terrorism and the war on terrorism" are promoting global stability and conflict resolution for a new SSA. We start off with some introductory issues associated with terrorism and the so-called war on terrorism. Then four contradictions are scrutinized, including the fact that terrorism elicits major socioeconomic fear and intimidation, technological advances provide greater opportunities for terrorists, deregulation also enhances terrorist actions, and the potential revival of US hegemony stimulates radical Islamic networks. Then conclusions are made about the significance of this for a new global SSA. 


\section{Terrorism and the war on terrorism}

Over the past decade, in particular, many planned attacks on civilians and others throughout the world have made terrorism a central concern in the global political economy. ${ }^{1}$ The vast majority of these attacks were agents of war. The "event" that "changed the world" was the September 11, 2001 attacks on the World Trade Center (WTC) and the Pentagon in the United States, which killed around 3,000 people. Since then there have been several other such attacks, such as the October 2002 suicide bombing in Bali which killed 202 people, the May 2003 bombing in Casablanca which killed 43 people, the March 2004 attack on the Spanish train system near Madrid which killed 191 people (and injured 1,800), and the July 2005 bombings in London that killed around 60 people. These and other attacks are said to be part of a wider, worldwide plan of attack by radical Islamic networks against US hegemony (including its allies) in the Middle East, the Persian Gulf, and elsewhere.

Of special concern to Osama bin Laden and his al-Qaida "terrorist" network is the aggression they see the United States as having wielded over Islamic nations. For instance, they complain that the United States has troops stationed in Saudi Arabia, a holy land of Islam. The United States has historically strongly supported Israel-militarily and diplomatically_against the "Palestinian people." The Unites States and its closest allies (the United Kingdom and Australia) are seen as having invaded Iraq with insufficient evidence of weapons of mass destruction. The UN-with the United States at its head (when it supported the UN)-disarmed and then stood by while some one-hundred thousand ethnic Albanians were slaughtered in 1998. And a recent part-ally of the United States, Russia, has been trying to defeat (or destroy) the Chechyan Islamic radicals in their bid for independence.

These actions and others have incensed bin Laden and his followers. He had earlier issued a Fatwas to all Muslims declaring a jihad or holy war on the United States and its allies:

[W]e issue [t]he...ruling [that] to kill...Americans and their alliescivilians and military-is an individual duty for every Muslum who can do it in any country in which it is possible to do it, in order to liberate the al-Aqsa Mosque and the holy mosque [Mecca] from their grip, and in order for their armies to move out of all the lands of Islam, defeated and unable to threaten any Muslim. This is in accordance with the words of Almighty God, [to]...fight the pagans all together as they fight you all together, [...and...] fight them until there is no more tumult or oppression, and there prevail justice and faith in God.

(bin Laden et al. 1998:2)²

After around 3,000 people were killed in the 2001 attacks on New York and Washington, DC, George W.Bush ordered the Taliban to give bin Laden up to face a military or international tribunal. They refused and in the midst of sympathetic UN resolutions favoring antiterrorist actions, the Afghan War started in November 2001. The combined air and ground forces of the United States. NATO, other nations, and the Northern Alliance managed to destroy most of the initial resistance put up by the Taliban, and a 
more broadly based Afghan government was able to be installed by February 2002. With elections having been held in late 2004, hundreds of captured Taliban and al-Qaida fighters have been held in Guantanamo Bay in Cuba for interrogation for some time now (and some of them are being tried in military courts).

US unilateralism spread as the US government put into practice the desire to strike first before terrorists and/or rogue states attacked the homeland again. Then the United States and its strongest allies-especially the United Kingdom and Australia-went into Iraq in 2003 to defeat Saddam Hussein on the erroneous pretext of his government having weapons of mass destruction and close association with Islamic terrorists. The second Iraq War has given radical Islamic activists another theater with which to develop networks and fighting capabilities. Estimates have it that well over 100,000 civilians and 2,000 US troops, among others, have been killed in this war. A new, more unilateralist policy has been instigated by the United States, under the influence of neo-conservatives, the American Enterprise Institute and others, to rid the world of so-called terrorists, renegade states, and the "axis of evil."

What are we to make of the continuing political-economic significance of these conflicts for the world and its people? Does it represent, as Lawrence Freedman (20012002) asks, the start of a Third World War that will impact greatly for some years to come? Does it represent, as Samuel Huntington (1996) believes, a major clash of civilizations, Islam and West, which will impact for many decades to come? Or could it be, as Charles Amjad-Ali (2001-2002) proposes, a passing phase of the evolution of the world-system where the United States seeks a meaningful form of dialogue with Islam? This chapter concentrates on whether the theater in which terrorism and the war on terrorism and rogue states is being played out is contributing to the emergence of a new global SSA, or whether there is too much uncertainty, instability, and conflict for this to be happening.

\section{Contemporary terrorism: nature and trends}

There are literally dozens of definitions of terrorism posited in the literature, which reveal its multifaceted nature, and lead to difficulties in obtaining consistent statistics. Close to the mark is M.V.Naidu's perspective that:

terrorism is the phenomenon in which a community is subjected to fear and terror through threats to human well being, and/or through...destruction of life, liberty and property of some individuals or groups [and where the]...targets of these threats and/or attacks are essentially [the] civilian population,...in pursuit of racist, religious, and ideological or political goals.

(2001:2, emphases added)

Usually when people talk of terrorism-as in this definition-they mean that certain actions have been taken by a group to kill, wound, threaten, or infect civilians, and which propel fear and intimidation within the social-psychology of a wider population. ${ }^{3}$ 
Terrorism is unleashed on civilians in many forms. Michael Walzer (2002), for instance, differentiates between revolutionary terror, war terror, and state terror; and I would add a fourth, namely "cultural terror." Of course, all four forms could be operating simultaneously, and are often closely related. Revolutionary or "political" terrorism includes the actions of a liberation movement (or its enemies) to force the hands of political leaders to yield on particular issues. Examples include the Irish Republican Army, the Palestine Liberation Organization, the Basque Separatist Movement, and the Algerian National Liberation Front. Recently, Islamic radicals are taking vague or very general concerns at a global or regional level as a basis of action. War terrorism is an attempt by a government or army to kill civilians in large numbers during a fullscale war in order to force the opposing army or government to surrender. The classic example is the dropping of atom bombs on Hiroshima and Nagasaki by the United States during the Second World War, resulting in the killing of over 100,000 civilians and the surrender of the Japanese government.

State terrorism usually includes war terrorism but is supposed to mean the targeting of civilians in peacetime, or the use of a state apparatus in one country to support an army that targets civilians in another. State terrorism in general (including the use of the state for war terrorism) is the most common form of terrorism - the greatest menace-and has elicited the greatest number of civilian deaths (see Sherman 2002). A good example is the destruction of native American culture and peoples by colonial and government armies during the 1700s and 1800s. Another is the attempted extermination of Aborigines in Terra Australas in the late 1700s and 1800s by the British and local authorities; especially through the introduction of smallpox viruses into the indigenous community (see Butlin 1983), and systematic shooting and other means. There is a fourth form of terrorism, what might be called cultural terrorism, where a dominant ethnic (or other) group kills or instills fear and intimidation into members of another group as part of the normal course of life. Usually, though, this requires the support of the state or other institutions such as the Church. Often those who are killed, intimidated, or denied due process are looked upon as inconsequential, since they are "no better than dogs," "savages," "underlings," whose life is said to be "worthless." A good example is the lynching of African Americans by the Ku Klux Klan and their associates between the 1870 s and the 1950s.

The new radical Islamic terrorism is a form of revolutionary terrorism, but it is also done within the context of a global war of radical Islam against the United States and its closest allies. It is undertaken in response to what it sees as US state terrorism, war terrorism in Iraq, and the support of reactionary states and/or organized terrorism in Israel, Saudi Arabia, and elsewhere. In order to comprehend the causes of the war on terrorism and the war on US hegemony, it is necessary to study the conflicting tendencies and processes of modem terrorism and the global political economy. Such conflicting tendencies are not simple; they are complex. One has to examine the strategic nature of terrorism, and the major sources of conflict emanating within the global political economy (see Kennedy 1998). Why does al-Qaida want to engage in weapons of mass destruction? Why do they use modern forms of technology? Why are they against US hegemony? Why hasn't globalization led the whole world to successfully join the club of business networks establishing shareholder value? How can there be different 
interpretations of Islam? Are the contradictions too strong so that uncertainty, instability, and conflict prevent the emergence of a global military SSA?

\section{Contradiction 1: terrorism-low fatality risk, high system risk}

This chapter seeks to critically evaluate the recent terrorism issue on the basis of the political economy notion of "contradiction." Contradictions are positive and negative aspects of a phenomena that are inherently related to its operational dynamics; aspects that cannot easily be separated from it. These inner contradictory dynamics are the forces that lead the phenomena to operate, but also the forces that lead to conflict and instability. It is critical for an understanding of political economy processes to analyze such contradictions, with a view to investigating whether they are capable of being moderated and if so how. This chapter examines four major contradictory dynamics of terrorism in the contemporary environment.

The first contradictory aspect of the inner motion of terrorism is this: terrorism has a relatively low risk of death for specific individuals, yet at the same time it often elicits a high level of social-psychological fear and uncertainty among the population. Historically, as shown by Table 6.1, compared with other risks of death-such as car accidents, suicide, murder, tuberculosis, and meningitis - terrorism poses an insignificant threat to the lives of human beings in the United States and most other places on Earth. The risk of being killed by terrorist acts is infinitesimal compared with these other major causes of death.

On the other hand, again historically, the political leadership and general public have a tendency to perceive terrorism as being a critical threat to their livelihood. People under the threat of terrorism tend to systematically overestimate it as a threat

Table 6.1 Worldwide fatalities of various sources of
death per 100,000 population, 1983-1997

\begin{tabular}{lrrrrrr}
\hline Year & \multicolumn{1}{c}{ Car accidents } & \multicolumn{1}{c}{ Suicide } & Murder & \multicolumn{1}{c}{ Tuberculosis } & \multicolumn{1}{c}{ Terrorism } \\
\cline { 1 - 2 } \cline { 5 - 6 } 1983 & 14.90 & 12.10 & 8.30 & 0.80 & 0.120 \\
1987 & 19.12 & 12.71 & 8.30 & 0.70 & 0.003 \\
1993 & 16.30 & 11.30 & 9.50 & 0.60 & 0.002 \\
1997 & 15.80 & $10.80^{\mathrm{a}}$ & 6.80 & 0.40 & 0.003 \\
\hline
\end{tabular}

Source: Adapted from Falkenrath (2001:170).

Note

a 1996.

to their life and livelihood. This is linked with the greater fear, intimidation, horror, and indignity that terrorist actions - especially the new form bend on mass killings - tend to create in the collective social consciousness. As a result, terrorist threats may create mass uncertainty and fear as people become more inward looking, or reduce their use of airline or train travel, or do not go to certain strategic destinations. 
According to opinion polling done by the Chicago Council on Foreign Relations in 1998-99-before the 11 September actions - 84 percent of the general public identified international terrorism as a "critical threat" to the United States, more than any other issue. Sixty-one percent of "leaders" identified international terrorism as a "critical threat," putting it just behind nuclear proliferation (67 percent) and chemical and biological weapons (64 percent).

(Falkenrath 2001:170)

Yet a similarly critical concern for vehicle fatalities or suicide is nowhere in sight, despite the much higher fatalities from these sources.

A paradox, which is implicit in the contradictory "multiplier" effects of terrorism, is that there appears to be an inverse relationship between the social-psychological consequences of fatalities and fatality probability or frequency, as shown in Figure 6.1. ${ }^{4}$ There are many reasons for the fact that people are more fearful of terrorist actions that are extremely unlikely to kill or maim them than they are of motor accident deaths, suicide, and murder that are much more likely to affect them directly. The first is that people get more fearful from conscious collective acts of killing than from activities that kill as a by-product of something useful, such as driving a car. Second, people are more fearful of terrorist acts that seek to kill as a political statement, than they are from many ad hoc killings that may be "crimes of passion" or the isolated acts of psychopaths. Third, people get scared more from a small number of critical fatalities concentrated in short time periods in specific sites than they do from many more fatalities spread over a larger time

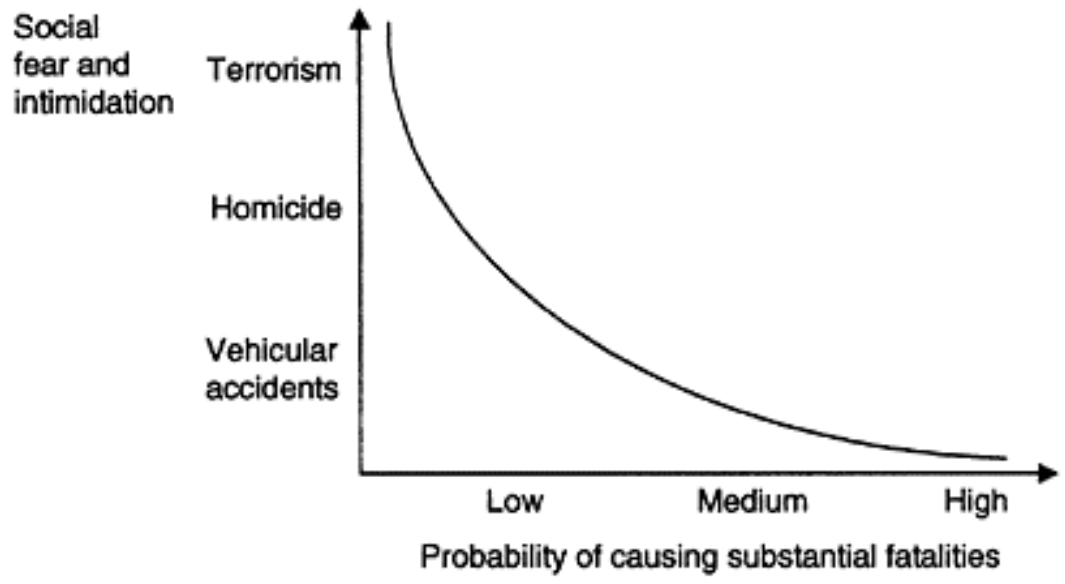

Figure 6.1 Terrorism consequencesprobability trade-off.

period in many locations. ${ }^{5}$ And fourth, rarely does a government seriously stimulate community debate about the nature of so-called terrorism, because they are interested in a 
military or strategic response and their desire to exploit the short-term advantages of being involved in patriotic fervor.

The general source of this dynamic is that there appears to be no real threat of fatality to the individual in the recent terrorist attacks, since anyone could have been hit, if they were near the source of the attacks. It is not a statistical problem for the individual, compared with other types of fatalities. But it surely is an attack on the system of US hegemony. Hence the general contradiction between individual and society: recent terrorism was unleashed so that there could be socioeconomic crises to upset the Untied States and other economies. Individuals were not targeted, only people who happened to be in or near icons of US capitalism associated with trade (the World Trade Centre), finance (Wall Street), and military dominance (the Pentagon), or tourist destinations and areas sympathetic to US interests.

Terrorists take advantage of this contradictory (or paradoxical) state of affairs: that terrorist acts pose a low risk to specific individuals, yet those same individuals feel fear and intimidation, nevertheless, due to social forces. Indeed, this is precisely the reason terrorists use such actions to advance their political or other objectives. It is a high impact action with a relatively low rate of fatality. Or more specific to al-Qaida's (and their allies') objectives, it creates fear and intimidation with relatively low cost for putting into operation. Hence al-Qaida were able to "produce" a high cost of death and destruction on September 11, 2001 ("social costs" to the United States) ranging from preliminary estimates of US\$60 billion to US\$1 trillion (Luke 2001:141; Homer-Dixon 2002:58).

These social costs are related to the circular and cumulative motion of modern terrorism. This shows how the terrorists use their belief system and jihad as the principal stimulus to action. The action manifests itself in the creation of various terrorist networks, which plan and activate strategic attacks, using various technologies. This new radical Islamic terrorism tends to depend upon two sorts of networks. One is an internal network of committed comrades, linked to a loose collection of like-minded radicals, as well as being supported by a diverse group of sympathizers, in turn associated with various governments and businesses. The second is the total network, including the media, the fatalities, and the population linked to the targeted group. The wider network is the source of its economies of scale and broad effectiveness, and is shown in Figure 6.2 .

This multiplier effect is a product of the effective use of technology, media response, and national sentiment. The governments of the affected peoples then respond to the situation. The combined influence of all these factors tend to create a circular and cumulative impact on the whole society. Successful attacks reinforce fear and intimidation, greater media coverage, and so on in a circular and cumulative fashion, with the cycle perhaps continuing through several runs. Many variants of the process are possible, such as a further attack, pro-terrorist actions, or war activated by the affected population's government, and so on.

The direct impact of terrorism on economic factors is fairly considerable: the IMF (International Monetary Fund), for instance, estimates the loss of US 


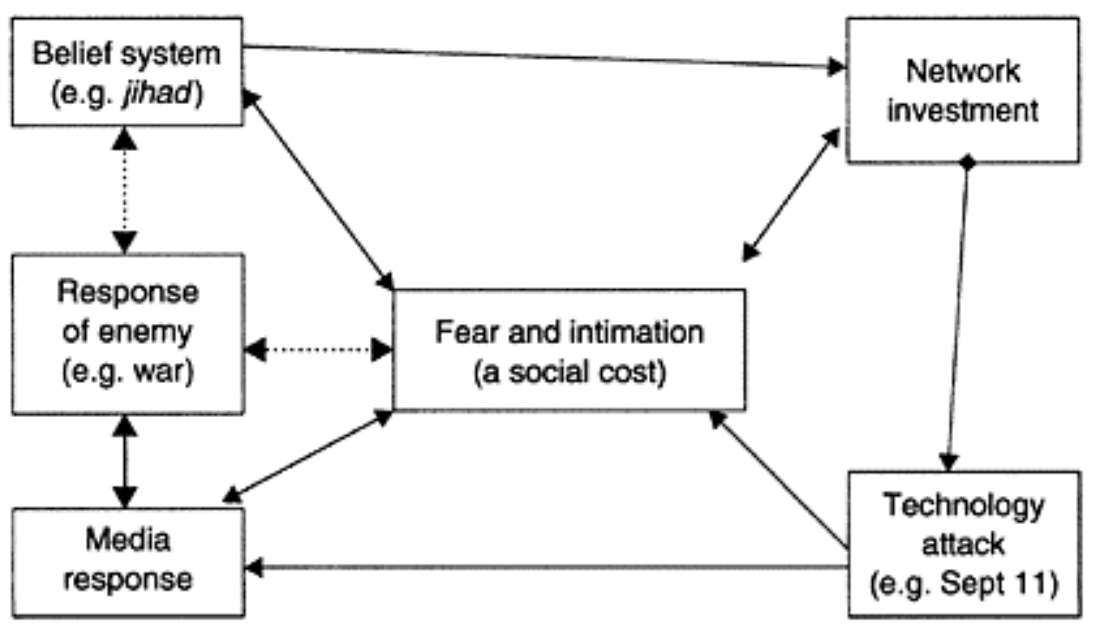

Figure 6.2 Circular and cumulative network effects of terrorism.

GDP (gross domestic product) from the September 11, 2001 attacks at between 0.75 and 1 percent. These include operating costs, inventories, risk, declining globalization of the United States, and so on (IMF 2001:19; global impacts are not included here). Bruno Frey et al. (2004:25) conclude from their study of terrorism that the "utility losses"-to human well-being in terms of life satisfaction-are "considerably larger than the purely economic losses." Together this indicates that the combined impact of the main 2001 terrorist attack on the United States alone may be as high as 3 percent of GDP. This is a considerable impact.

\section{Contradiction 2: technology promotes terrorism}

The latest opposition religious groups against US capitalism and hegemony are much stronger, powerful, and more concerned with mass casualties than just getting attention to their cause. They want to destroy US hegemony over Islamic nations and the Middle East. They find that US power corrupts people, dominates whole nations, and that the cultural foundations of outside dominance are morally repugnant. Instead, they believe in a particular reading of the Koran, reestablishing certain Islamic values and practices. Ironically, though, they appear to be using the power of capital, and some of the methods of production and reproduction typical of capital, to enhance their cause.

Contemporary capitalism is producing a massive technological infrastructure of machines, computers, airlines, weapons, buildings, and roadways that enhances its creative regeneration, accumulation, profitability, and systemic reproduction. But the very structures and dynamics of this technology can be just as effectively used by terrorists to sabotage-as Thorstein Veblen (1921) called it-both the system of technology and the institutions and relationships of capitalism. Sabotage refers to the process whereby the technological and network processes that propel production and reproduction of institutions and material 


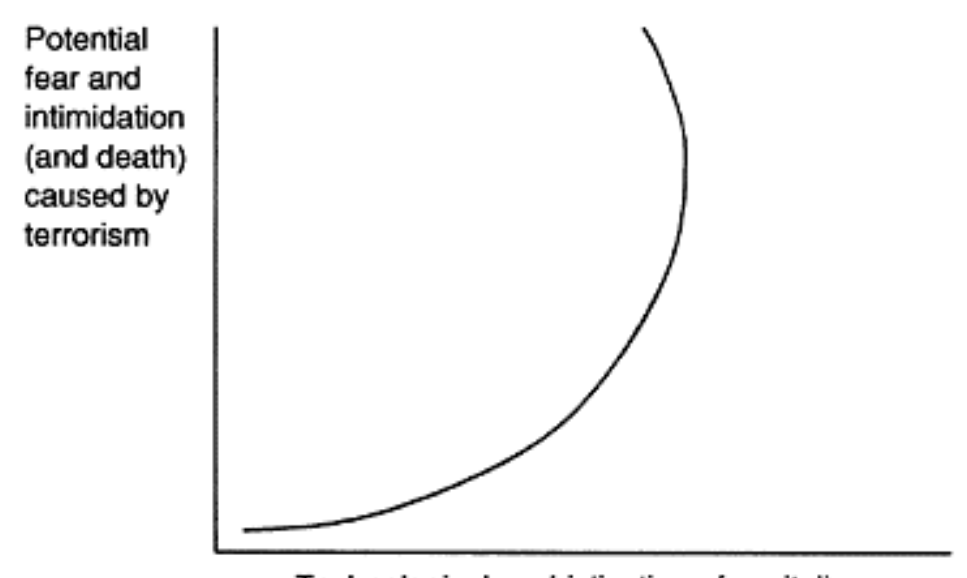

Technological sophistication of capitalism

\section{Figure 6.3 Contradictions of technology.}

output are being destroyed or adversely affected through conscious decisions of classes or other groups. In the process, they are able to increase fear, uncertainty, and instability while reducing expected profit and accumulation for the system. This goes to the very heart of US hegemony. A simple illustration of this contradictory relationship can be shown in Figure 6.3.

This shows that as the technological sophistication of capitalism increases, the potential for terrorists to utilize these structures of knowledge and technical competence to destroy such technology expands through historical time. The ability to sabotage is positively related to the degree of technological sophistication, at an accelerating rate, and that a point may be reached where the fear and intimidation starts to inhibit technology. Hence, sabotage could feasibly lead to a decline in technological sophistication through a sufficient acceleration of fear and intimidation. The fact is that the technological structures and dynamics of capitalism are increasingly capable of being used against itself by this new form of terrorism committed to the overthrow of US hegemony in the region. Modern technologies make it possible for the effective use of cyber-terrorism and weapons of mass destruction in the pursuit of extreme political, religious, and social beliefs that may completely disrupt society. The attacks on the WTC and the Pentagon were not low-technology events, as some analysts have suggested. The al-Qaida network used simple objects such as box cutters, knowledge of flying, and physics to convert commercial planes and jet fuel into modes of mass destruction-or at least high-tech killing machines_capable of killing thousands of people and destroying icons or US power and capability. As Juan Corradi states:

Contemporary societies make instruments of destruction possible as so many other commodities and make themselves, by that token, vulnerable. The more advanced and the freer the society, the greater the availability of do-it-yourself destruction. The means and opportunities have multiplied. 
The motives have evolved as well.... Technology makes it virtually impossible to distinguish between "peaceful” and "destructive” research and output. In a nutshell, contemporary violence, far from being a midwife of a new social system, is a state into which existing systems easily lapse.

The systems that are capable of being destroyed are networks or nodes of businesses, computer-information, highways, fiber-optic cables, railways, and defense arrangements that are interconnected, and complex relationships between institutions and people. As Gunnar Myrdal (1978) realized in his theory of circular and cumulative causation, the closer and more complex the network of interrelationships that are generated by these systems, the greater potential uncertainty, instability, and chaos that can result from their dislocation or destruction. An effective computer virus may destroy a whole network of business arrangements. A plane flown into a major building can reduce the perceived level of personal safety of a whole nation. A series of anthrax-laced letters has the potential to destroy a mail system. A nuclear device detonated in a series of major "public" spaces simultaneously_-such as Grand Central Station in peak period, Congress in mid-session, and a major league game in an exciting final quarter-can destroy the perceived security of a nation.

There are three main reasons or dimensions of technological vulnerability. First, modern technology has central nodes: critical sections, spaces, or areas that are the hub of the system, that can be disrupted quite easily. For instance, the "root servers" of computers are of this type. Second, capitalism has historically undergone various forms of centralization and concentration in particular areas and specific businesses. This is because of economies of scale and scope, and the high positive externalities of geographic location. Tacit knowledge, for instance, is often best developed in specific areas such as Silicon Valley, Wall Street, and Congress. And third, these centers and networks do not simply affect physical reality, but also virtual reality; and, more especially, the psycho-social networks associated with national symbols, national consciousness, and media outlets. The media is or has the potential to be the advertising agents of the terrorists-be they state terrorists, religious terrorists, or liberationmovement terrorists - either wittingly or unwittingly.

A critical factor enabling terrorists to "redirect the energies of our intricate societies against us" (Homer-Dixon 2001:58) is their degree of tacit knowledge. Explicit knowledge is the information necessary for the operation of a machine or other system; the blueprint that needs to be codified, or the instructions that need to be put into practice. Much more difficult is the tacit knowledge, which includes the experience of the practitioner, or knowledge gained through intuition that cannot easily be copied, or the knowledge that effectively applies something in practice (Brian Jackson 2001:187). It is this that the September 11 terrorists demonstrated to have an excellent grasp of. ${ }^{6}$ They showed great novelty by using a plane hijacking in a completely different way, almost as a series of simultaneous bombing campaigns. In this they benefited from a sustained process of research and development (R\&D) and the existence of a sound, decentralized form of network capital. 


\section{Contradiction 3: global deregulation expands terrorism}

This contradiction has three aspects to it. The first is that the emergence of globalization and neoliberal deregulation over the past two decades has seen the freer movement of capital-money, production, and goods-throughout most regions of the world, and that this has aided political terrorists by making it easier to build a global organizational terrorist network of human, social, financial, technological, advertising, and strategic capitals. Deregulation of global capital makes it easier for the terrorists to build resources against such a system, and in the process stimulate the development of a new structure of governance with more regulation on private capitals.

The second dimension of this contradiction is that neoliberal globalization has led to an increase in relative poverty and oppression-particularly between the West and the Islamic world - which is a breeding ground for terrorism (or revolutionary liberation groups). ${ }^{8}$ The spread of deregulated globalization increases the degree of uneven development in the world, which promotes rebelliousness in some of those areas that suffer in relative terms (Alehabib 1999). An increase in the number of graduates who are unable to find employment or meaningful activities promotes the stock of those capable of being the leading cadres in the radical Islamic movement against all of the "infidels" of the world.

This is linked to a third dimension of the contradiction: the double standard of the United States and Western diplomats, who talk about the need for human rights, cultural sensitivities, peace, and democracy - while at the same time seemingly showing little concern for the rights, cultural peculiarities, property, and governance structures of Islamic people. Many see this as a double standard. ${ }^{9}$ For instance, the United States will often unilaterally decide to intervene in a country if it thinks it is in its best interests. It also has historically supported its own forms of "state terrorism" against the civilian population of various-especially Islamic - nations.

These three dimensions-(1) deregulation and terrorism; (2) globalization and uneven development; and (3) the double standards of the United States-create various conflicts and instabilities. One particularly damaging result is the deep feelings in the Islamic world against the United States. Evelin Lindner (2001), for instance, isolates the humiliation of Islamic peoples: when the United States continues to support Israel against the "Palestinians," when it settles its troops in Saudi Arabia and supports a corrupt government (also in Egypt and the Sudan); when the United States and its allies invade Afghanistan without (as they see it) direct material evidence about complicity in the September 11 attacks; and-more recently — especially, when it invades Iraq without adequate evidence of weapons of mass destruction. For instance, in March 1985 the CIA organized a car bombing in Beirut that killed 80 civilians and wounded 256 while they were attending Friday prayers at the Imam Rida Mosque; "timed to kill the maximum number of people as they left" the service (missing their target, Shi'ite leader Sheikh Fadlallah) (Chomsky 2001). Also, over 100,000 civilians were killed in the US-led Gulf War of the early 1990s, and, according to Madeleine Albright, during 1991-2001 an estimated 500,000 children could have died as a result of US-inspired sanctions against Iraq (Editors 2001). Over 100,000 is the figure being used for possible civilian casualties so far in the second Iraq War (Roberts et al. 2004).

The lack of sympathy by the United States for Islamic ways and interests, and the inability of globalization and US power to positively influence the quality of life of many 
Islamic nations, has led many to engage in the "new" form of terrorism. Searching for roots of a better way of life for Islamic people that transcend domestic corrupt regimes and outside dominance, al-Qaida and their supporters represent a new generation of scholars, fighters, and common people seeking to reestablish self-respect and salvation for Islamic peoples. But they are just as much against so-called corrupt forms of Islam as they are in attacking the United States. As Appleby and Marty state:

Social context and the local or regional political culture have much to say about the directions that fundamentalism takes. Within the abode of Islam, nation states are either weak or failing, on the one hand, or dictatorial or repressive, on the other. Both contexts encourage violent variants of fundamentalism bent on replacing the state (as the Taliban did in Afghanistan) or overthrowing it (as the Shi'ites did in Iran and as radical Islamic groups have hoped to do in Egypt, Algeria, Saudi Arabia, and elsewhere).

\section{Contradiction 4: strategic US hegemony propelled terrorism}

During the 1950s-1960s the United States enjoyed hegemonic dominance in the world, with a caveat: there was also a relative military "balance" between the United States and the USSR (Wallerstein 1983; Bowles et al. 1992). In economic terms-production, commerce, and finance-the United States (in association with other Western nations) ruled the world, through the provision of leadership and at times coercion to establish public goods functions of stability and conflict resolution. Many authors concluded that, by the early 1970s, US hegemony had declined, reflected in defeat in Vietnam, declining productivity, and global and financial instability. Deep recession and financial instability of a periodic nature have been common since the 1970s. By the beginning of the 1990s the Eastern Block variety of so-called communism-or what some Western Marxists called "state capitalism" (Resnick and Wolff 1995)—was in absolute decline. The emergence of market socialism in China and Vietnam furthered the worldwide belief in market systems and, by the beginning of the twenty-first century (or during the 1990s), US hegemony was becoming reestablished in some respects as a result of a series of military campaigns and the short boom of the late 1990s.

During the 1980s the CIA did what it could to promote opposition to Soviet "control" in Afghanistan (as well as to the power elite in Iran and Yugoslovia). In doing so, it established a de facto strategic alliance with radical Islamic groups in Pakistan, Iraq, Afghanistan, and other nations. It supplied military, financial, and strategic support, for instance, to the Mujahideen, enabling the Taliban to come to power in Afghanistan. It continued to supply strategic and logistic support for these groups through the 1990s and early 2000s. Congressional reports of these activities are providing substantial support to this, according to Michael Chossudovsky, who says:

The various [US] Congressional reports confirm that the U.S. government has been working hand in glove with Osama bin Laden's al-Qaida.... The evidence amply confirms that the CIA never severed its ties to the 
"Islamic Militant Network"; the ties have become increasingly sophisticated The role of the CIA in supporting and developing international terrorist organizations during the Cold War and its aftermath is casually ignored or downplayed by the Western media.

(2001:35, 39, emphasis added)

What this implies is a central contradiction: the current power of the al-Qaida and many other Islamic terrorist networks is part and parcel of the decline of the Soviet system and the support the United States and specifically the CIA provided for the radical Islamic groups in the fight against international communism and secular Islamic governments such as Iraq. As Michael Mann (2001:66) says, "religious revivals have come to replace many socialist movements as self-proclaimed resistors of imperialism." In short, the United States hired the Muslim radicals_-combat fundamentalists," as Mann calls them - to fight secularity and communism, and in the process provided the foundation for the rise of international terrorism as a sophisticated network of worldwide groups and individuals. The WTC and Pentagon terrorist actions were thus influenced by US strategic support for terrorist organizations right up until the new millennium to help in its quest for renewed hegemony.

It is not simply that the United States supported terrorist organizations, but that it did so for purely strategic reasons, in order to promote the decline of Russian "communism" and the Iran/Iraqi states. It did not embrace the central concerns of the radical Islamic groups or attempt to include them in a durable set of diplomatic, military, and economic institutions. As the Mujahideen mercenaries, bin Laden, and later the Taliban realized, they were effectively being "used" in the interests of US foreign policy and military hegemony. No attempt was made to seriously and empathetically engage in theological debate on Islam, nor on the question of US influence in Saudi Arabia and support of a repressive administration there, and also not in relation to nationhood for Palestine (until very recently). US consumer capitalism and culture also symbolized the worst of sexual immorality, neocolonialism, and lack of respect for Islamic customs.

Hence, the United States not only encouraged terrorism but did it in such a way that the terrorists involved would not support the United States in the long run, that is, it remained a purely strategic and short-run alliance. The United States abused any longterm, durable alliance with the radical groups by entrenching their power in the Middle East. American troops were stationed in Saudi Arabia in an agreement with that government after the first Iraqi War. This humiliated bin Laden and his associates, being as it is, the holy land of Islam. American weapons and diplomatic support was also given to Israel against the Palestinians, Palestine being another holy land of Islam.

In response to what is perceived as US arrogance and dominance, Radical Islamic groups retaliated by bombing the WTC in 1993 (6 deaths, US\$500 million damage), bombing US embassies in Tanzania and Kenya (1998, 220+ deaths); bombing the US embassy in Nairoibi in 2001, undertaking the September 11, 2001 attacks on the WTC and Pentagon (2001, 3,000 deaths; US\$60 billion economic costs) (Bergen 2001:430; Burke 2001-2002:136; Falkenrath 2001:165; Luke 2001:141), and more recent attacks mentioned earlier in New York, Washington, DC, Bali, Morocco, Spain, Indonesia, London, and so on. The attempt to reestablish US hegemony and later unilateralism was 
thus undertaken in a crude fashion, without assessing the system-problems that emerge when the hegemonic power recklessly acts in regions such as the Middle East.

A real problem is the recent ascendancy of unilateralism and first strike doctrines of the US government. They have led to an escalation of conflicts, potentially creating "another Vietnam" in Iraq, mistaking rogue states such as Iraq for terrorists, and insufficiently supporting troops on the ground in Iraq to do the job "properly.” The post1945 multilateral framework of military and political treaties and organizations is gradually dissolving as the United States refuses to ratify the Kyoto Protocol, fails to join the International Criminal Court, treats the United Nations less than seriously, and takes an increasingly aggressive global stance. As the White House's 2002 National Security Strategy makes clear, the United States is trying to prevent potential threats to its power, furthering its military dominance, and trying to reproduce complete unipolar superiority over other nations and regions (White House 2002). However, this is a high risk strategy as global instability is increasing. As Philip Golub says that:

Ironically, the shift from hegemonic governance to militarism is likely to hasten rather than forestall US decline.... Today, even within its own core system, the Atlantic Alliance, US hegemony is increasingly perceived as illegitimate[.]... Despite the Bush administration's weak claims that it is providing a universal public good by subduing unruly "barbarians" in disorderly border zones, its policies are generating near universal dissent. The wrecking of the post 1945 legal and institutional [system] is leading to the unraveling of American hegemonic legitimacy... History tells us that such asymmetries are not sustainable. [A] US-centric world is on a unsustainable path.

$(2003: 3,5)$

And on the specific question of military outstretch and Iraq, he goes on to say in another article:

The general US strategy for dealing with Iraq, which has been based on predictions and recommendations of the neoconservative cabal in Washington, is becoming exposed at last as the disaster that informed analysts always knew it would become.... George W.Bush's imperial overreach is more likely to hasten rather than extend the century long American era.

$(2004: 780-782)^{10}$

\section{Conclusion}

The conclusions of this chapter are that the contradictions associated with terrorism, the war on terrorism, and the trend to a unipolar state are considerable. Conflict, instability, and uncertainty are inhibiting global accord through a number of avenues. First, terrorism has a low rate of fatality when compared to the major causes of death such as car accidents and murder, but it manages to instill a relatively high rate of fear and 
intimidation into a population in spite of such low fatalities. Terrorism in its many forms has recently increased the costs of undertaking business and consumption in the global economy. Second, the very foundations of modern technology and knowledge are used by terrorists (and their enemies) to attack such technology. The third conflicting tendency is multifaceted. In general it relates to the forces of globalization and neoliberalism around the world that helped stimulate the terrorist networks. And fourth, the very forces put into practice to reestablish US hegemony on the world against so-called communism helped to create this new form of terrorism that emerged from the power vacuum in the global political economy. The trend to unipolar military dominance and preemptive force is losing legitimacy and increasing conflict.

All four avenues are contributing to global instability and uncertainty in the Middle East, Europe, Asia, the United States, and Africa. The problems elicited by the United States and their enemies are likely to remain or even escalate. Unilateralism does not appear to be reducing such conflict and instability, but on the contrary, it is enhancing it by creating more wars and enemies. In this environment, the degree of global accord is insufficient to promote a global military SSA. The unipolar trend is creating wars that are unnecessary, conflict that could be averted and lack of accord that should be eschewed. As Chapter 10 points out, for a new military SSA it is critical to promote accords, cooperation, and global trust to reduce conflict and war in the global political economy. In this way uncertainty can be reduced and cooperation enhanced.

\section{Notes}

1 I wish to thank Hassan Bougrine, Jim Devine, Reynold Nesiba, and Howard Sherman for comments on a previous version of this chapter. I also wish to thank the participants of a seminar in which this was presented at Loyola Marymount University, Los Angeles and the meetings of the Association for Social Economics as part of the Eastern Economic Association in Boston (both in March 2002). Thanks are also due to the librarians at the Young Research Library at UCLA who were of considerable assistance. This chapter is dedicated to Howard Jay Sherman for his encouragement and friendship over the years. An earlier version of this chapter was published in Phillip Anthony O’Hara (ed.), Global Political Economy and the Wealth of Nations: Performance, Institutions, Problems and Policies (London and New York: Routledge, 2004), pp. 302-324.

2 A "personal message" from bin Laden to Muslims had specifically stated that:

It should not be hidden from you that the people of Islam had suffered from aggression, inequity and injustice imposed on them by the Zionist-Crusaders alliance and their collaborators; to the extent that the Muslims blood became the cheapest and their wealth as loot in the hands of the enemies. Their blood was spilled in Palestine and Iraq. The horrifying pictures of the massacre of Qana, in Lebanon are fresh in our memory. Massacres in Tajikistan, Burma, Cashmere, Assam, Philippine, Fatani, Ogadin, Somalia, Eritrea, Chechnya and in Bosnia Herzegovina took place, massacres that send shivers in the body and shake the conscience. All of this and the world watch and hear, and not only didn't respond to these atrocities, but also with a clear conspiracy between the USA and its allies and under the cover of the iniquitous 
United Nations, the dispossessed people were even prevented from obtaining arms to defend themselves, [sic]

3 The FBI's view seems to be problematic. They define terrorism as "the unlawful use of force or violence against persons or property to intimidate or coerce a government, the civilian population, or any segment thereof, in furtherance of political goals" (Sherman Jackson 2001:295). This has problems because it could include an army attacking the government or the military, and what is domestically "lawful" — according to state fiat-may still be terrorist, if the state legislates to allow state-terrorism.

4 The "terrorist multiplier" equation includes a number of variables. The first is the number of fatalities; deaths and serious injuries, such as the 3,000-odd deaths associated with the September 11 attacks. And the second is the ratio of the number of persons affected by-as well as the degree of-fear and intimidation. For instance, those directly affected by the September 11, 2001 attacks, in the form of fear and intimidation, could be defined as the population of the United States (280 million); and the degree of fear and intimidation could be called "relatively high" $(h)$. The multiplier effect $(m)$ of the terrorist activities is a ratio of the population affected ( $p, 280$ million), divided by the number of fatalities ( $f, 3,000$ people), multiplied by the impact (i, high):

$$
m=\frac{p}{f} i=\frac{280 m}{3000} h=9,333(h)
$$

\section{For instance, fatalities of around 3,000 people from the September 11 attacks have been able to instill a relatively high level of fear and intimidation into a national population of around 280 millon people in the United States.}

5 Even the 3,000-odd deaths from the WTC and Pentagon etc. strikes represent a relatively low number of deaths per 100,000 population relative to car accidents, suicide and murder. For instance, per 100,000 population for the United States as a whole, it represents 0.09 deaths per 100,000 population, compared with about 16 deaths per 100,000 for car accidents, 11 for suicide, and 7 for murder.

6 Some analysts, such as Jason Pate (2001:13), believe that the September 11 attack "is a very, very low technology incident." However, this is far from being the case. The attacks were part of a wideranging network of systems, including sophisticated internet communication, strategic use of multiple commercial planes, a high level of tacit knowledge and coordination, and the use of technological linkages between planes, buildings, and other technologies.

7 As Therese Delpech (2001:11) says: “Terrorism's financial backers skillfully exploit the weaknesses of the international fight against financial crime, while at the same time benefiting from the globalization and deregulation of markets."

8 However, as we suggest in many places, this is unlikely to lead to the inherent "clash of civilizations," posited by Samuel Huntington (1996), especially if policy and cultureresponse issues are handled well. Jonathon Fox's (2001) empirical research also casts doubt on the clash of civilizations thesis.

9 For instance, Tim Luke believes that

the US slowly turned away from many larger internationalist responsibilities that befell it as the world's sole remaining superpower. Instead of continuing to stand resolutely for unshakable modern ideals, 
like democracy, equality, and freedom, the US...permitted gangster capitalism to establish itself in places as varied as Russia, Columbia, and Rumania, and [did little] as horrendous civil strife racked areas in Africa, the Middle East, and Central Asia.

10 As Philip Golub goes on to say:

But overall, the US has suffered a deep and possibly irreparable loss of credibility and legitimacy throughout the world. The collapse of US legitimacy was already apparent prior to the revelations of torture, sanctioned by the highest levels of government, occurring in the archipelago of detention centers run by the United States. As the transnational polls of the PEW Center for the People and the Press highlight, the US's assault on the UN and the subsequent Iraq war caused a global backlash in world public opinion which has not subsided since.

(2004:780)

\section{References}

Alehabib, Eshagh. (1999) “The Role of Islamic Conference in Combating Terrorism,” The Iranian Journal of International Affairs, Volume 11, Number 4, pp. 524-540.

Amjad-Ali, Charles. (2001-2002) "How Did We Get Here? Caveats and Encouragement from History,” Cresset, Christmas/Epiphany, pp. 9-13.

Appleby, R.Scott and Martin E.Marty. (2002) “Fundamentalism,” Foreign Policy, January/February, pp. 16-22.

Bergen, Peter. (2001) “The Bin Laden Trial: What did We Learn?,” Studies in Conflict \& Terrorism, Volume 24, pp. 429-434.

bin Laden, Shaykh Usamah Bin-Muhammed. (1996) "Declaration of War Against the Americans Occupying the Land of the Two Holy Places," reprinted (as Appendix 1A) in Alexander Yonah and Michael S.Swetnam, Usama bin Laden's al-Qaida: Profile of a Terrorist Network, New York: Transnational Publishers.

bin Laden, Shaykh Usamah Bin-Muhammed, Ayman al-Zawahiri, Abu-Yasir Rifa’i Ahmad Taha, Shaykh Mir Hamzah, and Fazlul Rahman. (1998) "Jihad Against Jews and Crusaders: World Islamic Statement,” reprinted (as Appendix 1B) in Yonah and Michael S.Swetnam, Usama bin Laden's al-Qaida: Profile of a Terrorist Network, New York: Transnational Publishers.

Bowles, Samuel, David Gordon, and Thomas Weisskopf. (1992) Beyond the Wasteland, New York: Anchor \& Doubeday.

Burke, Jason. (2001-2002) “Portrait of the Terrorist as a Young Man,” Talk, December 2001/ January 2002, pp. 90-95, 98-99, 138.

Butlin, Noel George. (1983) Our Original Aggression: Aboriginal Populations of Southeastern Australia 1788-1850, Sydney: Allen \& Unwin.

Chomsky, Norm. (2001) “The United States is a Leading Terrorist State,” Monthly Review, Volume 53, Number 6, pp. 10-19.

Chossudovsky, Michel. (2001) “Osamagate,” Peace Research, Volume 33, Number 2, pp. 35-43.

Corradi, Juan E. (2001) “On Violence and Terror,” Telos, Number 120, Summer, pp. 147-153.

Delpech, Therese. (2001) “Embracing Death,” Internationale Politik: Transatlantic Edition, Volume 2, Number 4, pp. 9-12. 
Editors. (2001) “After the Attack...The War on Terrorism,” Monthly Review, Volume 53, Number 6, pp. 1-9.

Falkenrath, Richard. (2001) “Analytic Models and Policy Prescription: Understanding Recent Innovation in U.S. Counterterrorism,” Studies in Conflict \& Terrorism, Volume 24, pp. 150181.

Fox, Jonathan. (2001) “Two Civilizations and Ethnic Conflict: Islam and the West,” Journal of Peace Research, Volume 38, Number 4, pp. 459-472.

Freedman, Lawrence. (2001-2002) “The Third World War?” Survival: The IISS Quarterly, Volume 43, Number 4, pp. 61-88.

Frey, Bruno S., Simon Luechinger, and Alois Stutzer. (2004) Calculating Tragedy: Assessing the Costs of Terrorism, CESIFO Working Paper No. 1341. November 2004. Centre for Economic Studies and the IFO Institute of Economic Research. University of Munich.

Golub, Philip. (2003) “The American Hegemonic Cycle and System Wide Crisis.” Issues in Regulation Theory, Number 46, October 2003, pp. 1-4.

Golub, Philip. (2004) “Imperial Politics, Imperial Will and the Crisis of US Hegemony” Review of International Political Economy, Volume 11, Number 4, pp. 763-786.

Homer-Dixon, Thomas. (2002) “The Rise of Complex Terrorism,” Foreign Policy, January/February, pp. 52-77.

Huntington, Samuel. (1996) The Clash of Civilisations and the Remaking of World Order, New York: Simon and Shuster.

IMF (International Monetary Fund). (2001) World Economic Outlook—December 2001: the Global Economy after September 11, Washington, DC: IMF.

Jackson, Brian. (2001) "Technology Acquisition by Terrorist Groups: Threat Assessment Informed by Lessons from Private Sector Technology Adoption,” Studies in Conflict and Terrorism, Volume 24, pp. 183-213.

Jackson, Sherman. (2001) “Domestic Terrorism in the Islamic Legal Tradition,” The Muslim World, Volume 91, Numbers 3 and 4, pp. 293-310.

Kennedy, Moorehead. (1998) “The 21st Century Conditions Likely to Inspire Terrorism” in Harvey W.Kushner (ed.), The Future of Terrorism: Violence in the New Millennium, London and New Delhi: Sage Publications, pp. 185-207.

Lindner, Evelin Gerda. (2001) "Humiliation as a Source of Terrorism: A New Paradigm,” Peace Research, Volume 32, Number 2, pp. 59-68.

Luke, Tim. (2001) “On 9.11.01,” Telos, Number 120, Summer, pp. 129-142.

Mann, Michael. (2001) “Globalization and September 11,” New Left Review, Number 12 (second series), November-December, pp. 51-72.

Myrdal, Gunnar. (1978) “Institutional Economics,” Journal of Economic Issues, Volume 12, Number 4, pp. 771-784.

Naidu, M.V. (2001) “Anti-American Islamic Terrorism and War of Self-Defense,” Peace Research, Volume 33, Number 2, pp. 1-34.

O’Hara, Phillip Anthony. (2004) “The War on Terrorism, Political-Economic Contradictions and Policy Issues,” in Phillip Anthony O’Hara (ed.) (2004), Global political Economy and the Wealth of Nations: Performance, Institutions, Problems and Policies, London and New York: Routledge, pp. 302-324.

Pate, Jason. (2001) "Roundtable on the Implications of the September 11, 2001, Terrorist Attacks for Nonproliferation and Army Control,” The Nonproliferation Review, Volume 8, Number 3, pp. 11-27.

Resnick, Stephen and Richard D.Wolff. (1995) “The End of the USSR: A Marxian Class Analysis,” in Antonio Callari, Stephen Cullenberg, and Carole Biewener (eds), Marxism in the Postmodern Age, New York and London: The Guildford Press, pp. 323-332.

Roberts, Les, Riyadh Lafta, Richard Garfield, Jamal Khudhairi, and Gilbert Burnham. (2004) "Mortality Before and After the 2003 Invasion of Iraq: Cluster Sample Survey,” Lancet, Volume 364, Issue 9448, pp. 1857-1864. 
Sherman, Howard. (2002) “Terrorism, War and Institutions,” mimeo, University of California, Los Angeles, CA.

Veblen, Thorstein B. (1921) The Engineers and the Price System, New York: Harcourt, Brace \& World Inc., 1963.

Wallerstein, Immanuel. (1983) "Three Instances of Hegemony in the Capitalist World-System," International Journal of Comparative Sociology, Volume 7, Number 3, pp. 77-93.

Walzer, Michael. (2002) “Five Questions about Terrorism,” Dissent, Winter, pp. 5-16.

White House. (2002) The National Security Strategy of the United States of America, September, Washington, DC: White House.

\section{Further reading}

Bartsch, Sabastian. (2001) “Capitalizing Terrorism” Internationale Politik: Transatlantic Edition, Volume 2, Number 4, pp. 13-18.

Bulliet, Richard W. (2002) “The Crisis Within Islam” The Wilson Quarterly, Volume 26, Number 1, pp. 11-19.

Damphousse, Kelly R. and Brent L.Smith. (1998) "The Internet: A Terrorist Medium for the 21st Century,” in Harvey W.Kushner (ed.), The Future of Terrorism: Violence in the New Millennium, London and New Delhi: Sage Publications, pp. 208-224. 


\section{7 \\ A regime of accumulation for sustainable productivity and demand? ${ }^{1}$}

\section{Introduction}

So far in this study I have examined the contradictory institutional relationships of the Global System of Power and Accumulation. The conclusions made are that long wave upswing do not appear to have become activated. Suitable social structures of accumulation (SSAs) or modes of regulation (MORs) have not developed in the systems of global liberalism, transnational corporations, productivity-demand, global financetrade, and terrorism and the unipolar military system. The contradictory relationships are simply too intense to have a positive impact on socioeconomic performance.

For global long wave upswing to occur, a significant enough proportion of the (sub)continents need to undergo sustained growth and development. It is unlikely, however, that sustained upswing will occur without the United States being part of the recovery. For this reason, the following three chapters examine critical aspects of the US System of Power and Accumulation in order to assess the extent to which it may lead the rest of the world—or at least the advanced capitalist economies and East Asia—into long wave upswing into the early decades of the twenty-first century. Three main areas are examined: the regime of accumulation (ROA) associated with productivity and demand, the domestic financial system, and the system of family-community relationships. Neoliberalism is also relevant here as it is associated with all three aspects of the political economy. ${ }^{2}$

This chapter examines the question of whether a new ROA-or productionconsumption SSA-is developing at present in the US political economy. If a new ROA or SSA is developing, or is in large measure already in place, then-pending the outcome of the inquiry in Chapters 8 and 9 on finance and family-community-the United States can look forward to a considerable period of general long wave upswing with high growth, minor recessions, and minimal financial instability. If a new ROA and associated SSAs are not suitable, developing, or in place then periodic deep recessions and major financial instability are likely in the foreseeable future and long wave upswing is not currently operating. Of course, there are scenarios in between these two extremes that are possible as well.

According to most regulation school scholars (e.g. Tylecote 1992; Mazier et al. 1999), by the 1920s a new Fordist technological style was established in the United States, and later most other advanced capitalist economies, which by the late 1940s had boosted productivity. The dominant technical relations of Fordism included semi-automatic assembly line processes, mass production, economies of scale in the big corporations, and the utilization of an oil, coal, and combustion engine system of production. The Fordist 
technological style and long wave upswing could not be more fully developed until a mode of consumption, a system of social relations of production and distribution, and a series of institutional forms were created.

A suitable mode of consumption emerged in the late 1940s and early 1950s in most advanced capitalist nations, particularly the United States, within the context of a capitallabor accord in which big unions and big business agreed to divide the productivity gains between profits and wages. Organized labor tempered industrial unrest and control at the point of production in return for higher wages, which enabled the emergence of sustainable spending on consumer durables such as motor vehicles, televisions, refrigerators, and the like, and a network of suburbs, families, and associated state activities into the 1950s and 1960s. This enabled the symbiotic development of segmented labor markets, the deskilling of labor in a bureaucratic environment, and the linking of mass production with mass consumption in order to propel the circuit of capital into extended reproduction.

The Fordist ROA in the 1950s and 1960s thus constituted both a sustainable production system or style and a mode of consumption, not simply in the United States but through all the major capitalist economies. Such a regime reduced the conflict between capital and labor, thereby enabling the reproduction of capital through high levels of productivity, demand, and profitability. But the process of temporarily resolving some of the major contradictions of capitalism needed further development in relation to the conflict between industry and finance, firms in competition, national and world economy, and production and social reproduction. This was done through the process of establishing certain institutional (or structural) forms that complemented Fordism, such as a regulated financial system, a two-sector corporate system, the Bretton Woods agreement (and US hegemony), and the Keynesian-welfare state.

Long wave regulation scholars tend to argue that during the 1950s and 1960s there was a long wave upswing in the United States, while the 1970s-1990s was a period of downswing. This MOR analysis is supported by the reference cycle of US GDP (gross domestic product) growth, as shown in Figure 7.1. Long wave upswing during the 1950s and 1960s was characterized by annual average growth rates of 4.36 and 4.43 percent, respectively. During the 1970s the economy made the transition to long wave downswing, when annual average growth was lower at 3.34 percent; and downswing continued into the 1980s, 1990s, and 2000s with annual average growth rates of 2.91, 2.97, and 2.35 percent, respectively. The central message is that during upswing the capitalist economy is, in general, in a healthy state of expansion, with relatively minor recessions and minimal financial instability, while during downswings capitalism is beset by periodic deep recessions and financial instability, even if there are some strong booms in the short cycle. Typically, during long wave expansion, unemployment is on average 


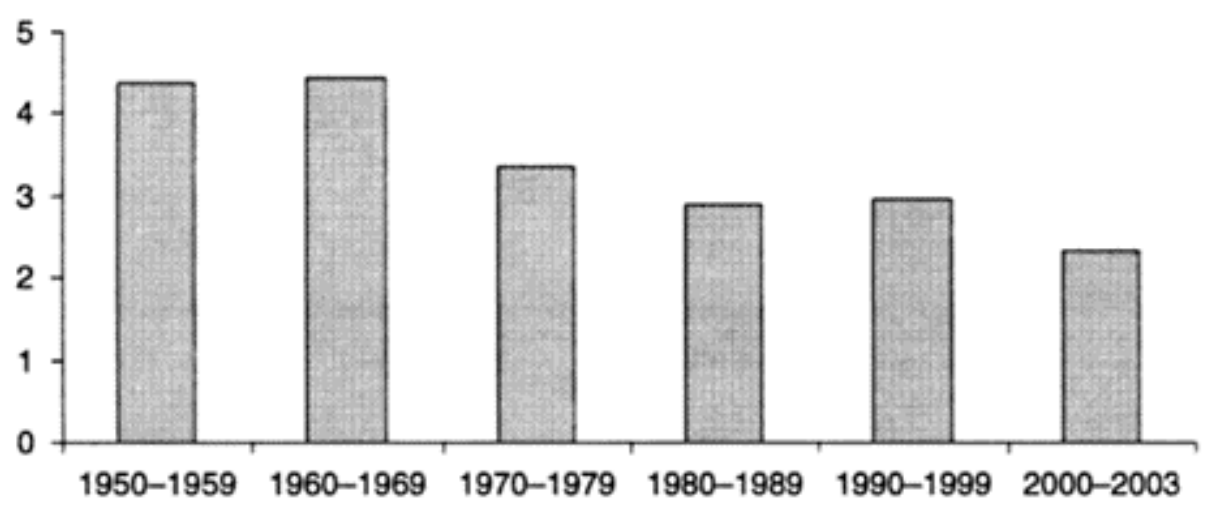

Figure 7.1 Real GDP growth rate: decade annual averages: United States, 1950-2003 (seasonally adjusted).

Source: Adapted from Bureau of Economic Analysis (2004:172-173).

relatively low because growth is high, while during long wave contraction, unemployment is on average high because of the deeper recessions and greater uncertainty.

These GDP growth rate patterns are mirrored by data for the US rate of profit, which is usually also a good proxy for the health of the capitalist system. Most studies of the US rate of profit for the 1990s and very early 2000s show an inflated figure for the years 1998-2000 — for instance, Landfeld and Fraumeni (2001) Dumenil and Levy (2002), and Brenner (2002) — due to the effects of corporate greed and inflated earnings figures to keep shareholder value high. ${ }^{3}$ As a result, the official data on profits has recently been revised downwards. As Charles Himmelberg et al. from the Federal Reserve Bank of New York state:

We have shown that revisions to corporate profits for the 1998-2000 period were unusually large and negative. The size of these revisions suggests that real-time data may have led markets and policymakers into thinking that corporate profitability was higher than subsequent profitability have revealed it to be. To the extent that corporate profitability helps determines stock prices and corporate investment, the overstatement of profits may have caused investors and corporate managers to misallocate funds over this period. ...[These] downward profit revisions for the years 1998, 1999, and 2000 totaled 11 percent, 9.3 percent, and 8.9 percent, respectively.

(2004:1, 6, emphasis added)

For the revised figures, in Table 7.1, the annual average after tax rate of profit for nonfinancial business corporations was 4.45 (1950s) and 4.40 (1960s) percent during 
long wave upswing, then declining to 3.62 (1970s) and 2.31 (1980s) percent, followed by a rise to 3.4 (1990s) percent and a decline to 2.57 percent (in the first four years of the 2000s) during long wave downswing. Net of the yield

Table 7.1 Average profit rate: the United States, 1950-2003*

\begin{tabular}{lrrr}
\hline & $\begin{array}{l}\text { After tax rate of } \\
\text { profit }^{\mathrm{b}}\end{array}$ & $\begin{array}{c}\text { Yield on 10-year US } \\
\text { treasury bonds }^{\mathrm{a}}\end{array}$ & \multicolumn{2}{c}{$\begin{array}{l}\text { Above normal competitive } \\
\text { rents }\end{array}$} \\
\cline { 2 - 4 } & 2.57 & 5.22 & -2.65 \\
$1900-2003$ & 3.40 & 6.66 & -3.26 \\
1999 & 2.31 & 10.60 & -8.29 \\
$1970-1979$ & 3.62 & 7.49 & -3.87 \\
$1960-1969$ & 4.40 & 5.11 & -0.71 \\
$1950-1959$ & 4.45 & 3.01 & +1.44 \\
\hline
\end{tabular}

Source: Adapted from Federal Reserve System (2000b $\left.{ }^{\mathrm{a}}, 2003^{\mathrm{a}}, 2004^{\mathrm{b}}\right)$.

Note

* The rate of profit is defined as the "profits after tax" for domestic nonfinancial corporationsincluding net dividends plus undistributed profits (table "F.7") — divided by tangible assets of nonfarm nonfinancial corporations (table “B.102”) (Federal Reserve System 2004).

on 10-year US Treasury Bonds gives a positive rent for the 1950s, a slightly negative one for the 1960s, then becoming increasingly negative into the 1970s and 1980s, and then during the 1990s and 2000s (due to a drop in inflation and interest rates) profits net of Treasury bond yields got somewhat better but have so far failed to return to the levels of the 1950s and 1960s.

During most of the long wave contraction of the 1970s-2000s the Fordist system deteriorated as profits declined, technologies matured and became transformed, productivity slumped, instability increased, and the whole system of sub-urban, family, and state structures evolved and became subject to contradictory processes. Most of the industrial nations of the world have been subject to major periodic financial instability and deep recession during the 1970s-2000s long wave downswing because of some combination of (a) a mismatch between the production and consumption modes, (b) these modes not being suitably developed, and (c) collectively the institutional forms not suitably enhancing the longterm reproduction of capital. A period of transition, instability, and readjustment has been in motion. The big question is whether a new macro MOR or SSA - comprising production style, consumption mode, and institutional forms-is being developed at present for the United States. ${ }^{4}$

\section{A new production style and sustainable productivity?}

Central to the current global workings of the leading transnational corporations in the "New Economy," is investment in automated processes, information and communications 
technology (ICT) and networks of relationships and business linkages. US companies are the leaders in ICT, and the US economy seems to be ahead of others in benefiting from the latest revolution in computing and electronic technology. ICT investment as a share of nonresidential gross investment has grown in the United States from 5.2 (1980) to 13.1 (1990) to 27.7 (2001) percent (OECD 2004:20), far ahead of all other OECD nations (OECD 2004:20). Hence, if any national economy is likely to be in the throes of a successful production style, leading the rest of the world, it is the United States. There are two interrelated aspects to the production style, the technical and the social relations of production, although in essence the differences are matters of emphasis.

The technical relations of production link to innovations from an expansion of entrepreneurial talent and expertise in areas of low cost electronics and data processing. Small or medium batch production is a key element of this new regime of production, with just-in-time methods of inventory control and supply chain management becoming more widespread (see Claycomb et al. 1999). Economies of scope (in addition to scale, depending on the firm or industry) is being used to reduce cost and increase productivity. New systems of office work, product design, and total quality management are important to the latest methods of production in the workplace. Financial services are also speeding their systems of accounting, enhancing margins, and downsizing, and firms are attempting to maximize shareholder value more explicitly as they come under the ownership of large financial or corporate interests (see Aglietta 2000). Multipurpose forms and diversity enhance the degree of institutional flexibility and cost reduction.

Some believe that a new style is emerging or is in large measure already in place; "a new techno-economic paradigm." There "is a trend towards information intensity rather than energy and materials intensity in production" which follows "directly from the very visible change in the general relative cost structure towards ever cheaper information handling potential through microelectronics and digital telecommunication" (Perez 1985:447; see also Tylecote 1995:5). For instance, the US producer price index for computers decreased from 231 (1988) to 100 (1995) to 32 (2001) (OECD 2004:87). Perez points out that, in product engineering, there is a tendency to redesign existing production systems so that they are smaller, with fewer moving parts, more electronic forms, and less energy intensivity. Increasingly, the internet is seen to be critical to these new systems of production as its use grew from 5 million users in 1993 to 100 million in 1998, with registered sites growing at an annual rate of 40-50 percent (Kenney and Curry 1999:131).

Business-to-business e-commerce currently accounts for 90 percent of online trade and is expected to dominate business-to-consumer e-commerce at least in the foreseeable future (Barnett 2000:1). Network externalities promote business interaction and provide considerable benefits to society (Madden et al. 2000:102). There is a trend toward both greater R\&D (Research and Development) investment intensity in US industries such as information and electronics. Industry R\&D intensity-measured as R\&D investment divided by sales-has increased from 1.8 percent (1977) to 2.02 percent (1981) to 3.2 percent (1988) to 3.77 percent (1995) in the United States. Of total industry R\&D, the information and electronics sector constitutes 43.6 percent of total R\&D activity, far ahead of the other sectors (Whiteley and Larson 2000). ${ }^{5}$

Tacit competencies constitute a critical system-building form of stability in an otherwise uncertain environment. Thus: 
The more tacit knowledge is, the more spatially concentrated we expect it to be. Since tacitness implies localization of development and greater context-specificity, and requires greater intensity of face-to-face interaction, knowledge transmission becomes more complex both within and across organizations... The transmission and absorption of knowledge takes on an informal and experimental character, thus requiring higher and more closely complementary technological competencies on the part of cooperating teams. This is the case, for instance, for many computerbased technologies.

(Cantwell and Santangelo 2000:145)

The more geographically concentrated technological sectors, based on tacit knowledge, include internal combustion engines, power plants, office and data processing equipment, cleaning agents, bleaching and dyeing, other electrical communication systems, distillation process, and semiconductors (science-based industries). Hence the development of regional systems of innovation. In this tacit and spatial concentration context, the United States has a clear advantage over most nations-especially those ultra-dependent upon the world economy-in having a large domestic market. It is this large domestic market in the United States that is a critical stabilizing process potentially enhancing growth and the new production style during the 2000s.

Some analysts have sought to view this new production style as a mostly benevolent system of social and production relationships. With flexible production, corporations can change product lines quickly, workers become more highly- and multi-skilled, production is oriented around teams of "associates," and the worker-friendly environment leads to a higher quality of life in the workplace. Supervisors are said to be becoming largely redundant, new unions are needed that cooperate with employers, and more people can have access to computers and other ICT products as prices for new technology products decline by 25 percent a year (Jorgenson 2001:9).

However, the social relations of production and distribution reveal a more complex reality. The new production style is being created in a social and political environment where, over the last two and a half decades, worker power has been effectively challenged. Neoliberal policies, deep recessions, company retrenchments, and the introduction of new technology itself were means of reducing the ability of workers to influence the outcome of wage negotiations and changes at the point of production. The economic environment changed from one of relatively high worker power to the current situation of a high level of power in the hands of capital. Also, the extent to which the flexible system of production is being created in the United States has been exaggerated since standardized products, mass production, and Taylorist work practices are more common than many realize. Also, the creation of flexible systems, lean production, and work teams - to the extent that they are developing — seem to be a means of increasing labor effort, speeding up assembly lines, reducing the number of workers, and contracting out tasks that can be outsourced (Yates 2001). ${ }^{6}$

The idea that the "New Economy" could fundamentally change the social relations of production and distribution-as distinct from modifying the technical relations of production-is difficult to believe in the face of a relatively constant mode of ownership, control, and management. We still have an economy based on the profit motive, a class 
system of production and distribution, the need to exploit labor and reinvest the rewards toward further accumulation and aggrandizing the few. "The truth is that in the most fundamental sense, i.e., social relations, there is nothing new at all about today's economy” (Yates 2001:12). As William Tabb says:

Technology in a capitalist economy is embedded in a set of social relations.... Companies in the 1990s learned more brazenly to fire longterm employees, outsourcing and subcontracting their jobs, replacing their traditional workforces with contingent and contract workers, and shifting core employment to a smaller New Economy cohort.... The connections between a rising high-tech segment of the stock market, widespread stagnation elsewhere, and more or less constant and falling real wages for the majority, need to be made clearly so that the celebration of the New Economy by politicians and the financial press can be better understood. Beneath the technological progress are the same old instabilities and social relations of capitalism.

(2001:2, 9)

Tabb believes that ICT has not been as dramatic as previous industrial revolutions in promoting productivity and sustainable economic growth. Is he correct? Certainly the new production style is well in place, and the United States did experience reasonably strong productivity growth at the height of the short-cycle boom in the late 1990s, and a much stronger boost in the early-mid-2000s. It does need to be stressed, though, that in a longer-term perspective, the productivity-GDP picture is not very impressive, as Table 7.2 indicates.

Over the past few decades until the mid-1990s, the inability of massive investments in information technologies to raise productivity in the business sector as a whole has become known as the "productivity paradox." For instance, according to Table 7.2, output growth per work hour in the United States was on average 2.72 percent in the 1950s and early 1960s, 2.54 percent in the later 1960s and early 1970s (long wave upswing), falling to 1.72 percent in the 1970 s, 1.20 percent

Table 7.2 Annual average decade growth rates of GDP, productivity, and related variables: the United States, 1954-2003

\begin{tabular}{|c|c|c|c|c|c|c|}
\hline & $\begin{array}{l}(1) \\
\text { Real } \\
\text { GDP } \\
\text { per } \\
\text { capita }\end{array}$ & $\begin{array}{l}\text { (2) } \\
\text { Output } \\
\text { growth } \\
\text { per hour }\end{array}$ & $\begin{array}{l}(3)=(1)-(2) \\
\text { Difference: } \\
\text { GDP minus } \\
\text { output growth }\end{array}$ & $\begin{array}{l}\text { Hours per } \\
\text { employee }\end{array}$ & $\begin{array}{l}\text { Employment } \\
\text { rate }\end{array}$ & $\begin{array}{l}\text { Labor force } \\
\text { participation } \\
\text { rate }\end{array}$ \\
\hline $\begin{array}{l}1954- \\
1963\end{array}$ & 2.08 & 2.72 & -0.64 & -0.16 & -0.02 & 0.03 \\
\hline $\begin{array}{l}1963- \\
1972\end{array}$ & 2.27 & 2.54 & -0.27 & -0.44 & -0.02 & 0.33 \\
\hline
\end{tabular}




\begin{tabular}{|c|c|c|c|c|c|c|}
\hline $\begin{array}{l}1972- \\
1978\end{array}$ & 1.49 & 1.72 & -0.23 & -0.60 & -0.06 & 0.73 \\
\hline $\begin{array}{l}1978- \\
1987\end{array}$ & 1.30 & 1.20 & 0.10 & -0.26 & -0.00 & 0.41 \\
\hline $\begin{array}{l}1987- \\
1994\end{array}$ & 1.63 & 1.48 & 0.15 & -0.01 & 0.06 & 0.23 \\
\hline $\begin{array}{l}1994- \\
2001\end{array}$ & 1.97 & 2.11 & -0.14 & -0.31 & 0.19 & 0.02 \\
\hline $\begin{array}{l}2001- \\
2003\end{array}$ & 1.01 & 4.52 & -3.51 & -0.46 & -0.92 & -0.27 \\
\hline
\end{tabular}

Source: Adapted from Gordon (2003:215, 217).

in the late 1970s and 1980s, 1.48 percent in the late 1980s and 1990s (long wave downswing). This is not a pretty picture for the production style, despite the fact that productivity in the information and communication technology sector has increased by an average annual rate of 24 percent in the 1990s (see Woodall 2000).

The OECD found that, after accounting for the cycle, aggregate productivity increased on average by about only 0.5 percent per annum during the 1990 s in the United States (and Australia, Canada, and the Scandinavian nations; but a smaller amount for almost all of Europe and Japan) (Woodall 2000). Some believe that productivity is difficult to measure in, for instance, the service sector. Robert J.Gordon (2001) attributed much of this late 1990s productivity increase in the United States to the short-cycle boom, believing, as a result, that IT had not improved business productivity (in a sustainable fashion) as much as the electricity and combustion engine technological styles did in earlier phases of capitalist development. ${ }^{7,8}$

Further work by Gordon (2003) has modified and updated productivity results. In the first place, data revisions have reduced the extent of the productivity revival of the late 1990s, and thereby enhanced the proportional contribution of ICT to the more modest productivity growth. But second, and more importantly, further work by Robert J.Gordon has shown that the productivity gains of the late 1990s were overshadowed (and in terms of trend the gains disappeared) vis-à-vis the gains during the early 2000s. Table 7.2 shows that productivity gains were high during the 1950s and 1960s, much lower during the 1970s, 1980s, and early 1990s, somewhat higher during the mid-late-1990s up until 2001, and then very high between 2001 and 2003.

However, these very high productivity growth rates between 2001 and 2003 were not related to growth in real GDP per capita, the difference between growth rates of GDP and productivity growth being a huge 3.51. These very high productivity gains around the time of the early 2000s recession and early recovery were mainly explained, as indicated in Table 7.2, by the high rate of decline in (a) hours per employee, (b) employment, (c) labor force participation, and some other variables not shown. During this time of such rapid productivity growth, capacity utilization was at a lower rate in 2002 than at any time since 1983 (Gordon 2003:247). At the same time, investment in ICT was in a severe slump. In short, the productivity surge was strongly countercyclical as the asset bubble crashed, and corporate crises and profit slumps stimulated firms to slash labor costs in 
order to boost productivity. The slashing of jobs for productivity gains cannot continue for a long wave upswing, however, as employment needs to grow substantially for a sustained upswing.

We thus appear to be experiencing a contradictory situation where a new production regime is emerging but without a sustainable (long-term) increase in productivity yet in sight. This does not auger well for the ROA or long wave upswing in the new millennium; at least not yet. It is too early to gauge longer-term trends at this stage, given the instabilities of the 1990s and early-mid-2000s. In the next section we explore an equally important question: whether the other face of the ROA-the mode of consumption-promotes sustainable demand through market expansion.

\section{The mode of consumption, bubble crash, and future performance}

This section examines the US demand regime to see what the potential is on this front for sustained GDP growth into the new millennium. Specifically, the ROA requires both a sustainable increase in productivity from the production style and a sustainable expansion of demand, in order to provide the foundations of long wave upswing. It seems unlikely that productivity is at this point sustainable. But is there a sustainable demand regime in the United States that could enhance long-term economic performance?

Figure 7.1, illustrates the high GDP growth rates for the 1950s and 1960s followed by much slower rates for the 1970s, 1980s, 1990s, and 2000s. If we decompose the GDP figures into its different components of demand, the data indicate that there are two main changes to the components of demand between the long wave upswing of the 1950s1960s and the downswing of the 1970s-2000s. This is shown in Table 7.3. The first is the switch from government expenditure to private consumption expenditure. While private consumption has increased from decade annual average levels of 62-63 percent of GDP during the long wave upswing (1950s-1960s) to between 64 and 70 percent during later periods (1970s-2000s), this has been at the expense of government expenditure (and net exports) which has progressively declined from an average 21.46 percent of GDP in the 1950s through to 18.27 percent in the 2000s. The second change is the greater balance of payments constraint as imports out-perform exports. While during long wave upswing the net export balance was positive, this changed during later years as net exports turned negative, equal to over 1 percent of GDP in the 1990s and a relatively huge four percent of GDP in the 2000s.

Thus, from the point of view of a sustainable mode of demand for long wave upswing, the following conclusions can be made. The first is that export demand is unlikely to sustain upswing, because the balance of trade is very much in the red as imports have exceeded exports and capital inflows have expanded. The resulting dependency upon capital inflow and current account deficits is likely to promote economic and exchange rate instability. The second conclusion is that,

$$
\begin{aligned}
& \text { Table 7.3 Demand components as a percentage of } \\
& \text { GDP: the United States, 1950-2003 }
\end{aligned}
$$

\begin{tabular}{|c|c|c|c|c|}
\hline Decade & Private & Fross nrivate & Fovernment & Fxnorts \\
\hline
\end{tabular}




\begin{tabular}{|c|c|c|c|c|c|c|}
\hline & $\begin{array}{l}\text { consumption } \\
\text { expenditure } \\
\text { C }\end{array}$ & & $\begin{array}{l}\text { domestic } \\
\text { investment } \\
\text { I }\end{array}$ & & $\begin{array}{l}\text { expenditure (all } \\
\text { levels) } \\
G_{C}+G_{I}\end{array}$ & $\begin{array}{l}\text { minus } \\
\text { imports } \\
X-M\end{array}$ \\
\hline $\begin{array}{l}2000- \\
2003\end{array}$ & & 69.86 & & 15.95 & 18.27 & -4.01 \\
\hline $\begin{array}{l}1990- \\
1999\end{array}$ & & 66.75 & & 15.07 & 18.92 & -1.08 \\
\hline $\begin{array}{l}1980- \\
1989\end{array}$ & & 64.35 & & 16.64 & 20.65 & -1.79 \\
\hline $\begin{array}{l}1970- \\
1979\end{array}$ & & 62.39 & & 16.75 & 21.22 & -0.46 \\
\hline $\begin{array}{l}1960- \\
1969\end{array}$ & & 61.82 & & 15.47 & 22.36 & +0.35 \\
\hline $\begin{array}{l}1950- \\
1959\end{array}$ & & 62.55 & & 15.77 & 21.46 & +0.23 \\
\hline
\end{tabular}

Source: Adapted from BE A (2004:167-168).

on current trends, government spending is unlikely to be a critical boost for sustainable upswing because government investment (especially) has declined somewhat as a percent of GDP. Government investment spending $\left(G_{I}\right)$ as a percent of government consumption spending $\left(G_{c}\right)$ has declined from decade annual averages of 24 percent (1950s) to 21 percent (1960s) to 12 percent (1970s) to 11 percent (1980s) to 10 percent (1990s) (BEA 2000:120-121). The third conclusion is that the main "positive" change in the composition of demand is that private consumption demand has increased markedly at the expense of government demand. Therefore, any discussion about a currently emerging mode of demand must center on this major trend: private consumption spending.

What, then, is the dominant dynamic of private spending in the 1990s-2000s? The US "boom" of 1997-2000 was a result of a combination of overseas and domestic developments. The (short) business cycle upswing was moderate until the 1997-1998 Asian crisis, when the US economy became more of a "safe haven" for foreign money and interests (Wincoop and Yi 2000). The safe haven function of the US economy became stronger as a result of the Russian and Brazilian economic-financial crises in the late 1990s. Capital moved from many "emerging economies" to the United States, often through offshore banking centers. In a circular and cumulative fashion: the US cycle upswing and relative domestic stability enhanced capital inflow, capital inflow provided much of the debt and capital underlying domestic private consumption (including equity holdings), domestic growth increased imports, expanded equity prices and led to the appreciation of the US dollar, which led to a further expansion of capital inflow and domestic wealth, which boosted private consumption (and investment) and thereby GDP, and so on ad infinitum.

The domestic market was a critical factor in the US boom for demand as well as technological change. With a population of around 293 million people, and an average 
income of US\$37,800 (CIA 2004), this gives the United States a total GDP of US\$11,810 billion, the largest in the world (third quarter of 2004; BEA 2004). A large internal demand provides the potential for a concentration of tacit knowledge, and regional systems of innovation, which constitute a major source of potential stability, profit, and resolution of conflict required for an ROA. 9,10

Despite the strong domestic demand, it may well be that the US (short) business cycle boom was unsustainable because such growth was based on consumer expenditure (in particular) that was financially overextended and not based on fundamentals. Much discussion has been generated about the 1990s "wealth effect" illustrated thus:

\section{$\uparrow \mathrm{US}_{\mathrm{sh}} \rightarrow \uparrow K_{\text {innow }} \rightarrow \uparrow D_{\text {ebt }} \rightarrow \uparrow E_{\mathrm{d}} \rightarrow \uparrow S_{\mathrm{p}} \rightarrow \uparrow W \rightarrow \uparrow C, I \rightarrow \uparrow \mathrm{GDP}$}

Due to the rise in financial-economic instability in emerging economies during the 1990s, the United States played a stronger role as a safe haven $\left(\mathrm{US}_{\mathrm{sh}}\right)$ for global capital flows, including bank credit, portfolio investment, and direct investment. Thus a large capital account surplus ( $K_{\text {inflow }}$ ) was balanced by a large current account deficit, as the US dollar appreciated and US growth expanded (due to the wealth effect) in the late 1990s. The greater debt $\left(D_{\text {ebt }}\right)$, partly from capital inflow, contributed to a rise in the demand for equities $\left(E_{\mathrm{d}}\right)$ in the mid-1990s, which led to a rise in both share prices $\left(S_{\mathrm{p}}\right)$ and wealth $(W)$ of consumers who traded in the market. And since consumption is in part a function of actual wealth, private consumption expenditure $(C)$ experienced a rapid expansion in the late 1990s through to 2000, which enhanced private investment (I), and thus GDP.

Evidence shows that the wealth effect of stock prices on consumption is higher in the United States, because the percentage of households who hold equity is more advanced here than elsewhere in the world, rising from 11 percent in 1985-1989 to 20.9 percent in 1996, and then a sudden jump to 24.4 percent in 1997 when stock prices started to really boom (IMF 2001:98) (subsequently declining). During the 1990s in the United States, it has been estimated that the direct effects of equity capital gains on consumption have been considerable, with between 5 and 15 cents in the dollar of a share market capital gain being spent by consumers over a two year period (Dynan and Maki 2001:27).

This would help explain the pattern of data shown in Table 7.4. These figures show that household liabilities actually exceeded the value of disposable income during 2000, consumption rose to an unprecedented 97 percent of disposable income, and wealth had risen to over six times income. This is quite a remarkable situation. For the first time in recent history, the household sector has become a net demander of funds, to the tune of 3.3 percent of GDP (Peach and Steindel 2000:4) as debt levels rose, based on actual capital gains. For the first time ever, consumer credit outlays have been over 20 percent of disposable personal income (FRS 2000a:624). Hence the historically low, traditionally defined, savings levels.

The Federal Reserve Bank of New York (Peach and Steindel 2000) calculate a relatively steady rate of savings when (modified) savings figures take into account the increased wealth of consumers. Based on such wealth figures, they conclude that consumers have not been borrowing and spending recklessly. However, this is based on the assumption that wealth did not decline suddenly, leaving them financially exposed. Hence, a critical question is the extent to which there has been a speculative bubble in the stockmarket, and the degree to which the bubble crashed during 2000-2004, resulting in a major drop in wealth. If a generalized speculative bubble existed, and then crashed, this 
shows the limits of the asset transmission mechanism in leading to sustainable expansion of demand.

Table 7.4 Households: liabilities, consumption, and wealth: the United States, 1990-2000

\begin{tabular}{lcccc}
\hline & 1990 & 1995 & 2000 \\
\hline Liabilities as a percent of disposable income $^{\mathrm{a}}$ & 87.22 & 93.97 & 107.89 \\
Consumption as a percent of disposable income $^{\mathrm{a}}$ & 89.18 & 91.16 & 96.67 \\
Wealth/income ratio $^{\mathrm{b}}$ & 3.0 & 3.2 & 6.3 \\
\hline
\end{tabular}

Source: Adapted from FRS (2001) and Dynan and Maki (2001) .

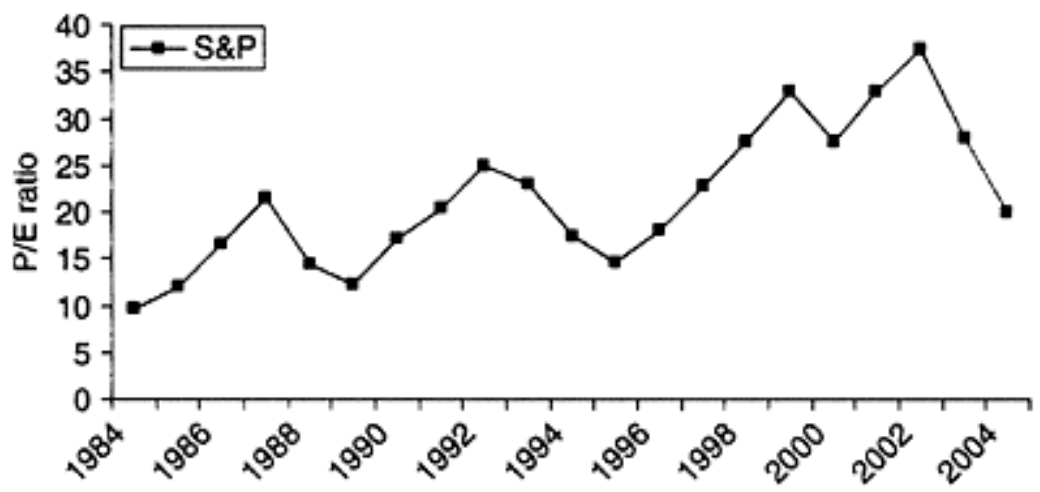

Figure 7.2 S\&P500 price/earnings ratio: the United States, 1984-2004.

Source: Adapted from Federal Reserve Bank of Cleveland (2004:7).

For instance, if the share price divided by corporate earnings (price/earnings ratio) ${ }^{11}$ above a certain level is a rough proxy for speculative bubbles, then it is highly probable that a large bubble existed during the late 1990s and then crashed in 2001-2004 in the United States. See Figure 7.2.

Figure 7.2 indicates that a positive bubble was present before the crash of 1987, during the early 1990s, and during the late 1990s. In 1987 a substantial correction was made; also during 1993-1994; and during 2001-2004. After the 1987 crash, speculators moved to commercial property, and after that crashed in 1989 recession emerged during 19901991. The decline in 1993-1994 resulted in a modest drop in retail sales and new manufacturing orders, plus a rise in inventories for a couple of years. The (short) business cycle upswing after the recession of the early 1990s did not become buoyant until 1997. The main difference between the rise and decline in the bubble during the early-mid1990s and during the late 1990s and early-mid-2000s is that the latter coincided with the boom and crash of internet and high-tech stocks. The 2001-2004 decline of the S\&P 500 
Index in the order of about 50 percent is, therefore, much more significant in terms of the future possible course of economic activity.

The pattern of the rise and fall of the Nasdaq-100 Index, an index of share prices for the leading companies in computing hardware, software, telecommunications, newtechnology wholesale and retail trade, and biotechnology, is shown in Figure 7.3 for the 1990s and 2000s. This shows how the speculative bubble in the Nasdaq Index crashed by around 80 percent during the period July 2000 to January 2003, wiping out all the gains made since mid-1997. Falls were not simple due to the crash of speculative bubbles per se, but also due to the terrorist crisis of late 2001 onwards (which probably stimulated the degree of bubble crash and reduced fundamental variables). Given that the boom in the late 1990s and early 2000s was, to a large degree, a result of the positive wealth effect of the equity market bubble increasing demand, a major decline in the S\&P500 bubble and a major crash of the Nasdaq-100 bubble are likely to indicate the limits of the

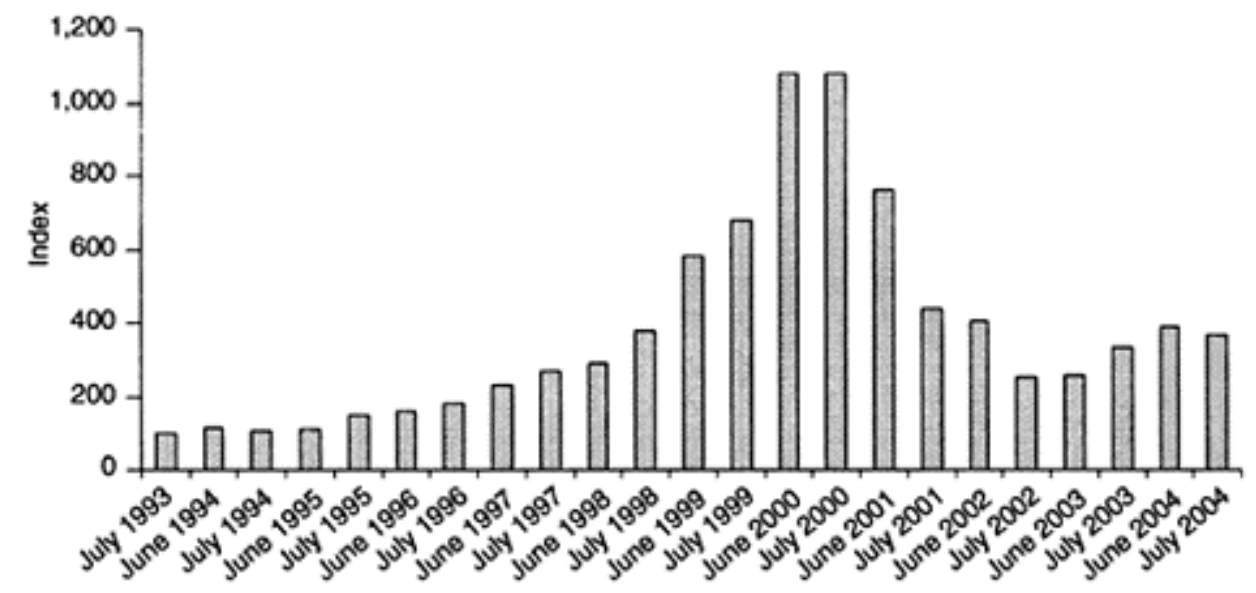

Figure 7.3 Nasdaq-100 Index: the United States, 1993-2004 (1993=100).

Source: Adapted from Nasdaq (2001:1, 2004:1).

equity transmission mechanism. When the financial system is directing resources into unproductive areas, through speculative bubbles and dubious corporate practices, then long-term economic activity is likely to be unsustainable and subject to considerable instability.

For instance, the decline in the equity market in the United States during 2000-2003 saw the total wealth of Americans decline markedly. Not since the last recession has there been a worse GDP result for consecutive quarters: $-1.9,-1.3$, and -0.2 percent decline for 2000:4, 2001:1, and 2001:2, respectively (BEA 2001). A negative wealth effect in the equity market was in motion during 2001-2003:

$$
\downarrow E_{\mathrm{d}} \rightarrow \downarrow S_{\mathrm{p}} \rightarrow \downarrow W \rightarrow \downarrow C, I \rightarrow \downarrow \mathrm{GDP}
$$


As traders came to realize that many of the high-tech and internet stocks could not live up to their potential earnings expectations, stock market confidence crashed during 20012003. A decline in the demand for equities led to a major drop in share prices, leading to a drop-off in wealth, and thereby reduced consumption, investment, and GDP. If every dollar decline in wealth reduces consumption by approximately 7 cents (within the band of 5-15 mentioned by Dynan and Maki 2001), then the 50 percent general drop in share prices is likely to have resulted in a decline in annual consumption of about US\$700 billion or 6 percent of GDP. Further multiplier and accelerator effects magnified this in a circular and cumulative fashion (see Palley 1999). ${ }^{12}$ The United States will likely weaken further as a safe haven for global capital flows, the value of the US dollar will likely dampen, and capital account surpluses will likely decline.

A critical problem is the narrow consumption base of the 1990s boom, depending as it did on the wealth effect of equity bubbles and greater debt financing of consumption. At the time of the equity crash, around 25 percent of the US population held shares, a massive increase from the 11 percent average of 1980-1984; double the figure of the United Kingdom, and six times the figure for Japan, France, and Italy (IMF 2001). While the mode of consumption underlying the 1950s-1960s long wave upswing was broadly based on the majority of the population; the consumption mode of the 1990s was based, at most, on a quarter of the population. Equities increased from 5 (1989) to 11.6 (1999) percent of average wealth, mostly for wealthy US citizens, and then declined suddenly. As Tracy and Schneider point out,

Poor households at the bottom of the wealth distribution own little equity or real estate, while households in the middle of the distribution hold most of their wealth in real estate and a small portion in stock. The wealthiest households have substantial holdings of both stock and real estate.

The boom of the 1990s was the most consumption-dependent cycle expansion for at least 50 years. Being based on share bubbles, it had little potential to be sustainable. The rising consumption of the working class and the poor during the 1990s was also unsustainable, since it was "accompanied not by rising real incomes for the majority of the population but stagnant wages” (Monthly Review Editors 2000). Between 1988 and 1998, relative income declined substantially for most of the population as a percent of the income of the wealthiest 5 percent: from 6.7 to 5.1 percent (bottom 20 percentile); 15.6 to 12.0 percent (21-40 percentile); 24.3 to 18.9 percent (41-60 percentile); and from 64 to 57.1 percent (61-80 percentile) (Frank 2000:255).

This major drop in relative income led even the poorest to try at least to "keep up with the Joneses" in relative spending patterns, which led to major increases in debt. The percentage of indebted families whose debt service payments were above 40 percent of their income increased from 27.6 percent in 1995 to 32 percent in 1998 for those with less than US\$10,000, from 17.3 to 20 percent for those with an income of US\$10,000$\$ 24,999$, and from 8 to 13.8 percent of income for those in the US\$25,000-\$49,000 income bracket. As a result, individual bankruptcies in the United States increased from 3,200 in 1994 to 5,000 per million population in 1999, even before the stock crash of 2000-2003 (Stavins 2000:17). 
Thus, as we move well into the first decade of the new millennium there does not appear to be a sustainable mode of consumption that encompasses the majority of the population. The stock bubble illustrates the limits of the wealth effect of the 1990s2000s, and the relative income expansion of debt for the lower segments of the population highlights the lack of a durable consumption mode for workers and the middle class. An alternative system of consumption emanating from overseas via exports is certainly not developing for the United States. Hence, from the demand side of things, no sustainable structure appears to be developing as yet for long wave upswing. As the editors of Monthly Review state:

It follows that increasing inequality in income and wealth can be expected to create the age-old contradiction of capitalism: on the one hand, sluggish consumer demand narrows the marketability of the goods that capital needs to sell; on the other, profitable investment opportunities depend ultimately on vigorous growth in the effective demand for consumer goods.

$(2000: 1)$

The analysis of this chapter to this point indicates that a new long wave upswing is unlikely to be in motion because a new sustainable ROA has yet to emerge. Sustainable macroeconomic productivity is unlikely to be forthcoming from the production style, and the demand influence of rising equity markets is not durable enough either. But a fuller comprehension of the potential for long wave upswing requires an analysis of certain social structures of accumulation (or 'structural forms'), such as the institutions of the financial system (Chapter 8) and the family-community (Chapter 9), as well as policies associated with a post neoliberal system of governance (Chapter 10).

\section{Conclusion}

We conclude, overall, that a long wave upswing of the US economy is unlikely to be in operation as we move into the new millennium because the "neoliberal" regime of accumulation is highly contradictory. First, the regime of accumulation is full of active conflicts and instabilities. The production style has not propelled sustainable productivity in the macroeconomy, much of the higher productivity of the late 1990s being due to the boom in the short business cycle while the boost in productivity during the early 2000s was mainly caused by shedding labor. Also, the boom was coevolving with a stock market bubble that enhanced consumption and debt through euphoric expectations that were not sustainable. Hence, it is likely that an adequate regime of accumulation has not yet emerged.

All-in-all, the "neoliberal" mode of regulation is, in all probability, unable to propel long-term stable growth, and the future of US (and world) capitalism cannot yet be seen to have begun a long wave upswing into the new millennium. However, we need to examine more areas of the US social economy so as to delineate more fully the potential for long wave upswing. Hence in the next two chapters we examine the US financial system and the system of family-community relations, respectively. This will give us a 
more comprehensive understanding of the nature of long-term prospects for the United States, and hence to some degree outline certain aspects of the potential of global capitalism.

\section{Notes}

1 A much earlier and shorter version of this chapter was presented at the ASSA meetings of the Association for Evolutionary Economics (AFEE), January 7, 2001, New Orleans, LA. I wish to thank the participants of this session, including Marc Tool, for helpful comments. A much earlier version was published in the Review of Radical Political Economics (see O'Hara 2003). Thanks also go to referees, Behzad Yaghmaian, Bruce Pietrykowski, and Jon Goldstein for many helpful criticisms and comments. Also thanks go to Harry Bloch and Peter Kriesler for helpful advice.

2 See O'Hara (2000b, 2003) for more detail about the doubtful feasibility of a neoliberal SSA in the United States.

3 However, even with the old, unrevised data, some analysts have assessed that the rate of profit has not recovered significantly. For instance, the work of J.Steven Landefeld and Barbara M.Fraumeni (2001) calculates the following before the proper revisions were made, and before recession emerged in the early 2000s:

\section{Average profit margin: the United States, 1948- 2000 (percentage)}

\begin{tabular}{llll}
\hline $1948-1973$ & $\frac{1973-2000}{10.50}$ & $\frac{1990-2000}{1080}$ & $\frac{1995-2000}{12.00}$ \\
\hline
\end{tabular}

Source: Adapted from Landefeld and Fraumeni (2001:24).

4 Much has been written about possible new modes of regulation. For instance, many political economists got excited about the potential for the flexible mode of production, including just-in-time methods of inventory control, total quality management, and the establishment of work teams and rotating tasks (see O'Hara 2000a). Others see the emergence of heterogeneous capital-labor regimes and a new international division of labor. Alain Lipietz (1997), for instance, argues that a neo-Taylorist system is dominant in the United States, the flexible system of production in Japan, and negotiated involvement in places such as Sweden. Andrew Tylecote (1995) sees a potential long wave upswing once the current dominant technological style of microelectronics and biotechnology is suitably matched by a set of micro, macro, and sociopolitical institutions. Behzad Yaghmaian (1998) argues that a new global MOR is in the making, and a long wave upswing is in motion according to Victor Lippit (1997) and Hossein-Zadeh and Gabb (2000). Fred Moseley (1999, 2000) doubts that sustained upswing has emerged Robert Boyer (2000) and Michel Aglietta (2000) raise the possibility of modifying the regulation approach on the basis of new institutions and processes, such as the financeled growth regime, shareholder value, and corporate governance, while Pietrykowski (1999) analyzes regulation trends within the context of the second industrial divide. Interesting early work is that of Ruccio (1989) and Tylecote (1992).

5 Many of the high R\&D sectors in the United States have been able to gain a global comparative advantage, such as in electronics, computing machines, instrumentation, aerospace, and pharmaceuticals; and intra-corporate trade constitutes an important part of the whole process (Papadakis 2000:142).

6 As Michael Yates (2001:10) says: Lean production aims at the maximum extraction of labor from human labor power, that is, at compelling workers to work with peak intensity for as 
many hours as possible. In automobile plants, for example, employees often work fifty-seven seconds out of every minute. It has nothing to do with empowering workers or making them more skilled, much less allowing them to make basic managerial decisions. The high-skill, high-wage workplace of the future is a pipedream.... [I]t is hard to see how even the highly skilled technical jobs associated with the electronic revolution will not ultimately show an erosion of skill. (2001:10) This message is similar to that documented by Carl Dassbach (1999) and Gordon (1996).

7 The acceleration of average US annual output per hour in the late 1990s, to the tune of 1.35 percent, was accounted for mainly by a cyclical effect (0.54), followed by computer capital deepening (0.33), higher multifactor productivity (0.29), and labor quality $(0.19)$. One reason for this disappointing result from information technology, according to Gordon, is that the main computer innovations, such as mainframe and personal computers, have already encountered a high degree of diminishing returns after the successes of the 1970s and 1980s. Other reasons relate to the peculiarities of the internet. For instance, the internet is used mainly for protecting market share against competitors, rather than expanding the range of services. The internet is also providing preexisting forms of information rather than new products and activities. It is often an alternative (duplicator of services) vis-à-vis mail-order catalogue shopping. And finally, a considerable amount of internet use at work is for leisure and consumption, "requiring” increased surveillance of workers (Gordon 2001).

8 Dale Jorgenson and Kevin Stiroh (2000) provide more favorable results for ICT than Gordon, especially for capital deepening, total factor productivity, and price decline. However, they emphasize the "uncertainty" about "the contribution of high-technology assets to the growth resurgence.” They note that "caution is warranted until productivity patterns have been observed for a longer period" because, should progress in high technology industries decline, the economy would be affected by both this decline as well as by decline in sectors that have a high use for such technology. Uncertainty also exists about "intermediate-term projections" due to "widening gaps in our knowledge." They also critique the simplistic view that ICT "spills over into every kind of economic activity and reveals its presence by increases in industry-level productivity growth across the U.S. economy. This view is simply inconsistent with the empirical evidence" (Jorgenson and Stiroh 2000:184-186).

9 The "national" orientation of the system of innovation constitutes the relatively stable aspect of the phenomena. Nevertheless, as Chris Freeman (2001:118) recognizes: "There is nothing in modern ICT, which eliminates uncertainty in relation to investment behaviour, the most important source of instability in capitalist economies" (original emphasis).

10 Makhija et al.’s (2000:122) empirical study of US industries demonstrates that "US industries are mostly multidomestic, particularly in comparison with other nations" mainly due to "the size of the domestic market and country distance." Nineteen of the twenty-seven US industries - most of the chemicals and manufacturing industries—are domestically orientated, including petroleum refining, automobiles, and military aircrafts. Some industries are also "simple global" which means that they use the domestic sector as a stepping stone to the world economy and are highly geographically concentrated (imports do not play a critical role), the motorcycle industry being a classic example. Industries that are "integrated global” include fertilizers and pesticides; engines and turbines; specialized industrial machinery and office equipment; office, computing and accounting machinery; and civilian aircraft. "Multidomestic" means that "competition in one country is largely independent of that in other countries"; while "multidomestic transitional" means that there is a "primary focus on the domestic industry along with a significant, although uncoordinated export orientation" (Makhija and Williamson 2000:105). "Integrated global” means "a high level of international competition" and "highly dispersed value-added activities," while "simple global" means that "the scope of competition transcends domestic boarders [but...] involves the use of the home country as an export platform to reach international markets," where 
"firms have a geographically concentrated configeration” (Makhija and Williamson 2000:105-106).

11 The price/earnings ratio is a standard tool of sharemarket analysis. It is defined as: $P / E$ Ratio=(Market Value of Share $) /($ Earnings per Share $)$, where the market value is the share price weighted for the importance of the companies in the index, and the earnings per share is the after-tax profit per share weighted for the importance of the companies in the index.

12 This would be compounded by the fact that a significant portion of the higher-echelon workers have been receiving stock options instead of wage increases; and the declining share market will negatively impact on their labor supply, including productivity (see Dean Baker 2000:16).

\section{References}

Aglietta, Michel. (2000) "Shareholder Value and Corporate Governance: Some Tricky Questions," Economy and Society, Volume 29, Number 1, pp. 146-159.

Baker, Dean. (2000) “The Supply-Side Effect of a Stock Market Crash,” Challenge, Volume 43, Number 5, pp. 107-117.

Barnett, C. (2000) “E-Legacy: The IP Systems Challenge,” Journal of General Management, Volume 25, Number 4, pp. 1-16.

BEA (Bureau of Economic Analysis). (2000) “GDP and Other Major NIPA Series: 1929-2000:1,” Survey of Current Business, August 2000.

http://www.bea.doc.gov/bea/\%20ARTICLES/NATIONAL/NIPA/2000/0800gdp.pdf (accessed February 2, 2002).

BEA. (2001) Gross Domestic Product: First Quarter 2001 (Preliminary); Corporate Profits: First Quarter 2001 (Preliminary), May 25, 2001.

http://www.bea.doc.goc/bea/\%20newsrel/gdp.101p.htm (accessed February 9, 2002).

BEA. (2004) Gross Domestic Product and Corporate Profits. November 30. http://www.\%20bea.doc.gov/newsrel/gdpnewsrelease.htm (accessed December 20, 2004).

Boyer, Robert. (2000) "Is a Finance-Led Growth Regime a Viable Alternative to Fordism? A Preliminary Analysis,” Economic and Society, Volume 29, Number 1, pp. 111-145.

Brenner, Robert. (2002) "The Trajectory of the Manufacturing Profit Rate: A Reply to Dumenil and Levy,” Review of Radical Political Economics, Volume 34, Number 3, pp. 49-56.

Cantwell, J. and G.D.Santangelo, (2000) "Capitalism, Profits and Innovation in the New TechnoEconomic Paradigm,” Journal of Evolutionary Economics, Volume 10, pp. 131-157.

CIA (Central Intelligence Agency). (2004) The World Factbook. December 2004. http://www.cia.gov/cia/publications/factbook/geos/us.html\#Econ (accessed December 28, 2004).

Claycomb, C. (1999) "The Effects of Just-in-Time with Customers on Organizational Design and Performance,” The International Journal of Logistics Management, Volume 10, Number 1, pp. 37-58.

Claycomb, Cindy, Cornelia Dröge, and Richard Germain. (1999) “The Effect of Just-in-Time with Customers on Organizational Design and Performance,” The International Journal of Logistics Management, Volume 10, Number 1, pp. 37-58.

Dassbach, C.H.A. (1999) "Lean Production in North America: Myth and Reality,” in Riccardo Bellofiore (ed.), Global Money, Capital Restructuring and the Changing Patterns of Labour, Cheltenham, UK and Northampton, MA: Edward Elgar, pp. 111-123.

Dumenil, Gerard and Dominic Levy. (2002) "The Profit Rate: Where and How Much Did It Fall? Did It Recover? (USA (1948-2000),” Review of Radical Political Economics, Volume 34, Number 3, pp. 437-461. 
Dynan, K.E. and D.M.Maki. (2001) "Does Stock Market Wealth Matter for Consumption?,” Federal Reserve System, discussion paper series. 2001-2004 (May).

Federal Reserve Bank of Cleveland. (2004) "Money and Financial Markets,” Economic Trends, June, p. 7.

Frank, R.H. (2000) “Does Growing Inequality Harm the Middle Class?” Eastern Economic Journal, Volume 26, Number 3, pp. 253-264.

Freeman, Christopher. (2001) “A Hard Landing for the 'New Economy?' Information Technology and the United States National System of Innovation," Structural Change and Economic Dynamics, Volume 12, pp. 115-139.

FRS (Board of Governors of the Federal Reserve System). (2000a) "Credit Cards: Use and Consumer Attitudes, 1970-2000,” Federal Reserve Bulletin, Volume 86, Number 9, pp. 623634.

FRS. (2000b) Long-Term U.S. Government Securities: 1925-2000 (discontinued series). http://www.forecastes.org/data/data/LTGOVTBD.htm (accessed July 3, 2001).

FRS. (2003) Rate of Interest: Long Term or Capital Market: Government Securities: Ten Year, http://www.federalreserve.gov/h15/data/a/tcn10y.txt (accessed August 9, 2003).

FRS. (2004) Flow of Funds Accounts of the United States: Annual Flows and Outstandings. 19452004, Washington, DC: FRS.

Gordon, David M. (1996) Fat and Mean: The Corporate Squeeze of Working Americans and the Myth of the Managerial Downsizing, New York: The Free Press.

Gordon, Robert J. (2001) “Does the 'New Economy' Measure up to the Great Inventions of the Past?,” Journal of Economic Perspectives, Volume 14, Number 4, pp. 49-74.

Gordon, Robert J. (2003) "Expanding Productivity Growth: Context, Causes, and Implications,” Brookings Papers on Economic Activity, Number 2:2003, pp. 207-279.

Himmelberg, Charles P., James M.Mahoney, April Bang, and Brian Chernoff. (2004) "Recent Revisions to Corporate Profits: What We Know and When We Knew It," Current Issues in Economics and Finance, Volume 10, Number 3, March, pp. 1-7.

http://www.newyork.org/\%20research/current-issues

Hossein-Zadeh, Ismail and Gabb, Anthony. (2000) "Making Sense of the Current Expansion of the U.S. Economy: A Long Wave Approach and a Critique,” Review of Radical Political Economics, Volume 32, Number 3, pp. 388-397.

IMF. (2001) World Economic Outlook, May 2001: Fiscal Policy and Macroeconomic Stability, Geneva: International Monetary Fund.

Jorgenson, Dale W. (2001) "Information Technology and the U.S. Economy.” American Economic Review, Volume 91, Number 1, pp. 1-32.

Jorgenson, Dale W. and Kevin J.Stiroh. (2000) "Raising the Speed Limit: U.S. Economic Growth in the Information Age,” Brookings Papers on Economic Activity, Number 1, pp. 125-235.

Kenney, Michael and James Curry. (1999) "E-Commerce: Implications for Firm Strategy and Industry Configuration,” Industry and Innovation, Volume 6, Number 2, pp. 131-151.

Landefeld, J.Steven and Barbara M.Fraumeni. (2001) "Measuring the New Economy,” Survey of Current Business, Volume 81, Number 3, March, pp. 23-40.

http://www.bea.gov/\%20bea/about/newec.pdf (accessed January 6, 2003).

Lipietz, Alain. (1997) “The Post-Fordist World: Labour Relations, International Hierarchy and Global Ecology,” Review of International Political Economy, Volume 4, Number 1, pp. 1-41.

Lippit, Victor. (1997) "The Reconstruction of a Social Structure of Accumulation in the United States,” Review of Radical Political Economics, Volume 29, Number 3, pp. 11-21.

Madden, Gary, Scott Savage, and Grant Coble-Neal. (2000) "Internet Adoption and Use" Prometheus, Volume 18, Number 2, pp. 161-173.

Makhija, M. and S.Williamson. (2000) "The Globalization of US Industries" in T.L.Brewer and G.Boyd (eds), Globalizing America: The USA in World Integration, Cheltenham, UK and Northampton, MA: Edward Elgar, pp. 98-133. 
Mazier, Jacques, Maurice Basle, and Jean-Francois Vidal. (1999) When Economic Crises Endure, Armonk, NY and London: M.E. Sharpe.

Melkers, J. and K.Willoughby. (1998) "The State of the States: Performance-Based Budgeting Requirements in 47 out of 50,” Public Administration Review, Volume 58, Number 1, pp. 6673.

Monthly Review Editors. (2000) "Working Class Households and the Burden of Debt," Monthly Review, Volume 52, Number 1, pp. 1-8.

Moseley, Fred. (1999) "The United States at the Turn of the Century: Entering a New Era of Prosperity?” Capital and Class, Number 67, pp. 25-45.

Moseley, Fred. (2000) “The Rate of Profit and Stagnation in the U.S. Economy,” in R.Baimon, H.Boushey, and D.Saunders (eds), Political Economy and Contemporary Capitalism: Radical Perspectives on Economic Theory and Policy, Armonk, NY and London: M.E. Sharpe, pp. 5967.

Nasdaq. (2001) Nasdaq-100 Index. July 14, 2001. http://dynamic.nasdaq.com/dynamic/\%20nasdaq100_activity.stm

Nasdaq. (2004) Nasdaq-100 Index. November 26, 2004. http://dynamic.nasdaq.com/\%20dynamic/nasdaq100_activity.stm

OECD (Organisation for Economic Cooperation and Development). (2004) The Economic Impact of ICT: Measurement, Evidence and Implications, Paris: OECD.

O’Hara, Phillip Anthony. (2000a) Marx, Veblen and Contemporary Institutional Political Economy: Principles and Unstable Dynamics of Capitalism, Cheltenham, UK and Northampton, MA: Edward Elgar.

O’Hara, Phillip Anthony. (2000b) “The Evolution of a New 'Neoliberal, Balanced Budget' Social Structure of Accumulation? Emerging Prospects for the United States and World Economies," in Hassan Bougrine (ed.), The Economics of Public Spending: Debts, Deficits and Economic Performance, Cheltenham, UK and Northampton, MA: Edward Elgar, pp. 30-56.

O’Hara, Phillip Anthony. (2003) "Deep Recession and Financial Instability or a New Long Wave of Economic Growth for U.S. Capitalism? A Regulation School Approach.” Review of Radical Political Economics, Volume 35, Number 1, Winter, pp. 18-43.

Palley, Thomas. (1999) “End of the Expansion: Soft Landing, Hard Landing, or Even Crash?” Challenge, Volume 42, Number 6, pp. 6-25.

Papadakis, M. (2000) “Technology in the Globalization of the USA,” in T.L.Brewer and G.Boyd (eds), Globalizing America: The USA in World Integration, Cheltenham, UK: Edward Elgar, pp. 134-153.

Peach, R. and C.Steindel. (2000) "A Nation of Spendthrifts? An Analysis of Trends in Personal and Gross Saving,” Current Issues in Economics and Finance (Federal Reserve Bank of New York), Volume 6, Number 10, pp. 1-6.

Perez, C. (1985) "Microelectronics, Long Waves and World Structural Change: New Perspectives for Developing Countries,” World Development, Volume 13, Number 3, pp. 441-463.

Pietrykowski, Bruce. (1999) "Beyond the Fordist/Post-Fordist Dichotomy: Working through The Second Industrial Divide,” Review of Social Economy, Volume LVH, pp. 177-198.

Ruccio, David. (1989) “Fordism on a World Scale: International Dimensions of Regulation,” Review of Radical Political Economics, Volume 21, Number 4, pp. 33-53.

Stavins, J. (2000) "Effect of Consumer Characteristics on the Use of Payment Instruments," New England Economic Review, September, pp. 19-31.

Tabb, William K. (2001) “New Economy...Same Irrational Economy,” Monthly Review, Volume 52, Number 11, pp. 33-40.

Tracy, J. and H.Schneider. (2001) "Stocks in the Household Portfolio: A Look Back at the 1990s," Current Issues in Economics and Finance (Federal Reserve Bank of New York), Volume 7, Number 4, pp. 1-6.

Tylecote, Andrew. (1992) The Long Wave in the World Economy, London and New York: Routledge. 
Tylecote, Andrew. (1995) “Technological and Economic Long Waves and their Implications for Employment,” New Technology, Work and Employment, Volume 10, Number 1, pp. 3-18.

Whitley, R.L. and C.F.Larson. (2000) "Industrial Research Institute’s First Annual R\&D Leaderboard,” Research Technology Management, Volume 43, pp. 25-35.

Wincoop, E.van and Kei-Mui Yi. (2000) "Asia Crisis Postmortem: Where did the Money go and did the United States Benefit?,” Economic Policy Review, Volume 6, Number 3, pp. 51-70.

Woodall, P. (2000) "Survey: The New Economy: bubble.com,” The Economist, 23 September, pp. S19-S25.

Yaghmaian, Behzad. (1998) "Globalization and the State: The Political Economy of Global Accumulation and its Emerging Mode of Regulation,” Science and Society, Volume 62, Number 2, pp. 241-265.

Yates, Michael D. (2001) “The 'New' Economy and the Labor Movement,” Monthly Review, Volume 52, Number 11, pp. 11-20. 


\section{8 \\ A financial social structure of accumulation?}

\section{Introduction}

This chapter studies the second aspect of the US System of Power and Accumulation: the financial system. ${ }^{1}$ It examines the question of whether the current US economy has developed a viable financial social structure of accumulation (FSSA) (or "structural form") to contribute to long wave upswing, or whether, on the other hand, the financial system contributes to the emergence of periodic deep recession and financial instability through long wave downswing. Or is the "truth" somewhere in between: financial structures and dynamics are only partly evolved so as to enhance long-range growth or reduce financial instability. We concentrate (but expand somewhat) on Martin Wolfson's (1994a) notion that a new (financial) SSA requires a sustainable level of (a) stability, (b) conflict resolution, and (c) profitability. ${ }^{2}$ These three factors are critical to the potential FSSA through the circuit of money capital.

\section{Financial SSA: conditions and dynamic structure}

The conditions necessary for a new FSSA - sufficient stability, conflict resolution, and profitability - are related to the circuit of social capital, in particular, the circuit of money capital. This is illustrated in Figure 8.1. The circuit of money capital illustrates the phases and stages involved in the general motion of the circuit of social capital (see Palloix 1975 for more detail). All the phases of the circuit interlink in a complex cybernetic system of motion. Money and credit $(M)$ are required to spur the process into action via corporate relations and financial institutions. These largely endogenous sources of funds, propelled by the demand for finance, activate the sourcing of labor power (LP) and means of production (MOP). This enables production value chains to be formed (............), thereby enhancing the process of valorization, resulting in the production of surplus product (c). The commodity value $(C)$ and surplus product (c) need to be sold or traded on the market (the "effective demand problem") for value $(M)$ and surplus value $(m)$ to be generated. Then the reinvestment process becomes reactivated to varying degrees through the circuits. Each of the four phases of the circuit-financing/investment, sourcing, production, and sale and reinvestment-are institutionally linked through corporate and other structures. 


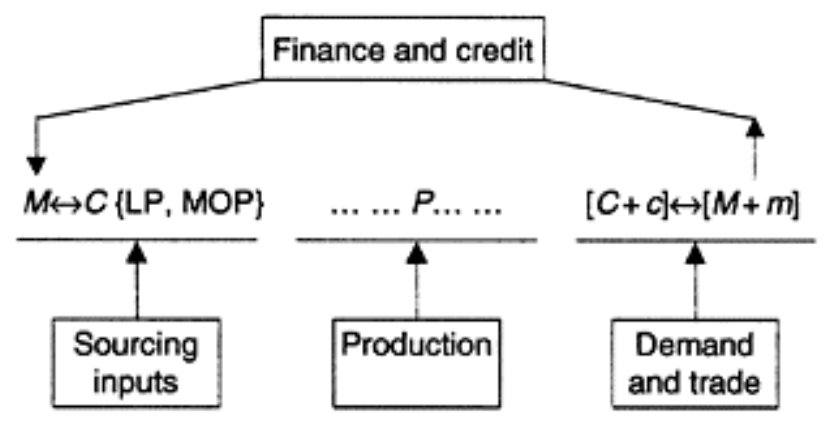

Figure 8.1 Circuit of money capital.

The SSA (social structure of accumulation) and regulation schools of political economy argue that this circuit of social capital cannot operate through purely market arrangements, and that networks of institutions provide the organizational, network, and social capitals upon which long-term economic performance is based. The economy needs to be embedded in a series of institutional organizations, agreements, bodies and dynamic structures of finance, sourcing, production, and trade in order to enhance the workings of the complex circuit. ${ }^{3}$ Adequate financial stability, conflict resolution, and profitability are hypothesized to be the main criteria necessary for the establishment of a new SSA within the circuit through the process of institutional embeddedness. ${ }^{4}$

Financial stability is important, first, in order to propel a sufficient degree of coherence and continuity to the circuit; to reduce the potential variance of capital flows, prices, interest rates, and GDP (gross domestic product); since "the rotation of capital can be disrupted in any of the...stages" (Dillard 1987:1639). This is critical in order to reduce the potential for financial crises, contagion, chains of bankruptcy, and hence deep recession. The monetary circuit thus requires not only that there be a relatively high level of continuity and fluidity to economic transactions and processes, but also that some minimal level of stability be present so that this continuity is maintained in the long term. The FSSA requires a balance between maintaining the speed of the circuit and minimizing the turbulence of financial flows.

Second, a sufficient level of conflict resolution, is required for a new FSSA, to instill a workable arrangement between financial and industrial capitals. ${ }^{5}$ This necessitates that financial capitals facilitate the building of fundamental variables such as workmanship, industrial innovation, and long-term profit for industry. The conflict between financial and industrial capitalists needs to be moderated in such a way that industrial capitals have the edge over financial capitals, as Karl Marx, Thorstein Veblen, J.M.Keynes, and Hyman Minsky all recognized in their monetary theory of production (see Dillard 1987). If the rate of return is not sufficiently high in the industrial areas (relative to financial areas) then the circuit of social capital will be inhibited through the development and crash of speculative asset bubbles. If financial capital is relatively autonomous from industrial capital, then the industrial workings of capitalism become a sideshow to the main game of speculation and the "earning something for nothing" mentality of business. The concerns of industry thus need to be the dominant focus of the economy, rather than 
the quick returns of the "unproductive" areas, for the emergence of relatively sustainable growth and accumulation.

Third, for the financial system to enhance long-term growth and accumulation, it is necessary for banks and other financial institutions to demonstrate that they are operating with a relatively high level of productivity, profitability, and customer orientation. Such conditions should be ongoing, beyond the short term, and consistent with the necessary degree of financial innovation. The innovations should be directed at promoting industrial and consumer financial needs, as well as enhancing the stable fluidity of the circuit. The financial institutions need to keep abreast with the latest techniques and instruments and, at the same time, adjust to the requirements of industry and households, while keeping an eye to long-term profitability. The financial system needs to be technically efficient while satisfying the monetary and fiscal requirements of society at minimal cost.

These three functions of the "circuit of social capital" provide the potential public goods that may promote socioeconomic embeddedness, providing a degree of "social protection" necessary to counter the potential dominance of the "self-regulating market" (Polanyi 1944:132). If these conditions are provided to a sufficient degree, the circuit of money capital is able to expand in a sustainable fashion through the phases of sourcing of inputs, production of value, realization through exchange, and generation of investment via the flow of funds. The reproduction of the circuit is thus propelled in a manner that enhances stability, conflict resolution, and long-term performance through the development of a new FSSA. Much depends on the ability of business or government to protect system-functions that are crucial to the long-term propagation of capital. Is the current operation of the circuit consistent with these functions, or are the contradictions of the system propelling periodic financial crises and deep recession? First we examine the major elements of the contemporary financial system.

There are six major aspects to the current workings of the financial regime within the circuit of social capital. The current structure emanates from, first, the neoliberal deregulation of the financial system that was implemented in the United States during the reign of (especially) Presidents Ronald Reagan, George Bush, Bill Clinton, and now George W.Bush in the late 1970s to the 2000s. ${ }^{6}$ Deregulation of the financial system led to interest rates, exchange rates, share market prices, wages, and prices to be more market friendly. The government thus no longer puts ceilings on interest rates, no longer fixes exchange rates, no longer seeks to control the share market, and is keen to maintain a relatively flexible labor market. The idea behind this is that if you make markets more flexible and price conscious, resources are drawn into those areas with higher rates of return. If markets are more efficient then financial gains are said to expand expected dividends and the long-term profitability of industry (see Coggins 1998).

Second, out of the deregulated financial system emerges a computer and high-tech oriented financial system where money as notes and coin constitutes a small proportion of transactions. Electronic Funds Transfer at Point of Sale (EFTPOS), Electronic Funds Transfers (EFT), Internet banking, and electronic foreign exchange, bond, equity, and bank transfers have turned the financial system into a Chartelist system where, in some limited sense, "there is no limit to which credit can expand in response to an increase in demand for credit” (Wray 1998; Kadmos and O’Hara 2000). The US system is more dependent upon checking accounts than most advanced nations, but this payment method is, along with electronic methods, consistent with the lowest ratio of cash/GDP in the 
world at around 20 percent (Lacker and Weinberg 1998; Humphrey et al. 2000; Stavins 2001). Endogenous finance operates through various, mainly electronic, instruments such as bank bills, certificates of deposit, capital inflow, trade credit, options, swaps, capital inflow, and reserve bank "accommodation." Hence the emergence of a monetary circuit where finance is not a "veil," but rather impacts on the real economy in complex and time-dependent ways in the monetary production economy (Arestis and Eichner 1988).

A third part of the structure is shareholder value. This is the tendency for the recently increased power of shareholders to place more emphasis on firms maximizing the value of their equity. Managers are under more pressure to resort to short-term returns to investment and trade. This includes activities such as company takeovers, mergers, globalization, expanding market value, effective advertising, and putting more viable commercial projects into action. Financial institutions, in particular, tend to replace their staff with computer-managed systems of financial transactions. Large flows of funds can move via these electronic sources internationally at short notice as the money capital circuit becomes more mobile. Sharemarkets constantly monitor and assess firm performance, profitability, and dividend potential (Aglietta 2000). More individuals as a result were buying and selling shares during the late 1990s (in particular) in the equity market in the United States (double that of the late 1980s) than at any other time (see IMF 2001), although the dominant players are institutional traders and Mutual Funds.

A fourth structural element of the regime is the development of a global system of financial flows. Foreign currency markets in most nations are now flexible, although some important nations do try and put "grains of sand" (or even small stones) into the system to slow down market-determined relationships through capital controls, currency boards, or other means. By and large, though, the circuit of money capital is able to expand quickly, at the global level, with the press of a computer button. This applies to all forms of international money capital, from FDI to portfolio flows and bank loans. In this way, many nations are able to exercise large capital account deficits or surpluses according to the supply and demand for many different currencies, although many deal only in US dollars. Inflows into the US economy seem to be reacting to the "safe haven" role of the US economy, whereby certain types of uncertainties may be reduced through trading or investing in the United States; hence one reason why the United States has a large capital account surplus (Wincoop and Yi 2000). The free flow of the circuit is also encouraging more currency unions and other forms of integration between nations.

The fifth part of the system is a regulatory environment dominated by monetary policy. Because credit money is endogenous the government does not control the money supply (Rochon 1999). Instead it “manipulates” interest rates on government securities that are supposed to influence other variables such as consumption, investment, and GDP. Fiscal policy, on the other hand, has been used less regularly than monetary policy in affecting macroeconomic variables such as GDP and prices (at least until the recent tax cuts and increased defense spending). There has been a substantial switch over the past 30 years from government investment in public capital to the financing of transfer payments, and the less productive use of fiscal policy (Weber 2000). Monetary policy is strongly linked with the flow of funds of the private sector that it supposedly influences. Questions arise as to how effective such a policy can be in the era of globalization, finance capital, and information technology (Goodhart 2000; Copper and Little 2001; O’Hara 2004). 
The sixth structural element of the US financial system is the recent spate of mergers and other forms of consolidation. Deregulation, innovation, economic problems, financial crises, and the spread of nonbanks opened up the financial system to major changes. The 1980s saw the crisis in the savings and loan associations, including widespread closures and takeovers, while the 1990s saw a series of mergers through the development of bank holding companies, and the start of a national banking system. Some authors argue that this, ironically enough, led to greater competition as more banks could operate in a given geographical area, despite consolidation, and through the emergence of more nonbank financial institutions (Broaddus 1998). Other authors argue that, increasingly, bank holding companies own numerous banks so that-even though the number of banks has increased - the number of independent groups of banks have declined (Stiroh 2000).

How does this financial system impact on the macroeconomy? Robert Boyer (2000:111) suggests the possibility of a "finance-led accumulation regime," that "combine[s] labour-market flexibility, price stability, developing high tech sectors, booming stock market and credit to sustain the rapid growth of consumption, and permanent optimism of expectations of firms." This chapter assesses whether such an accumulation regime is in place and effective in propelling sustained economic performance. An illustration of the regime is shown in Figure 8.2.

This finance-led circuit is Chartel in the sense that there are apparently no specific limits to the generation of endogenous credit through certificates of deposit, bank credit, bills of exchange, global credit, and government money. The limits are based mainly on the level of confidence able to be generated by the system. Recent innovations, such as options, swaps, and futures, enable a higher level of credit without apparently increasing risk in the short run. Firms are able to utilize credit to purchase equity and also to start projects that enhance shareholder value and hence potential dividends. The expansion of shareholder value leads to equity price growth, and hence wealth, which expands debt and consumption, and through the multiplier also investment and GDP. Through the Verdoorn effect of economies of scale/scope and learning by doing, productivity is enhanced.

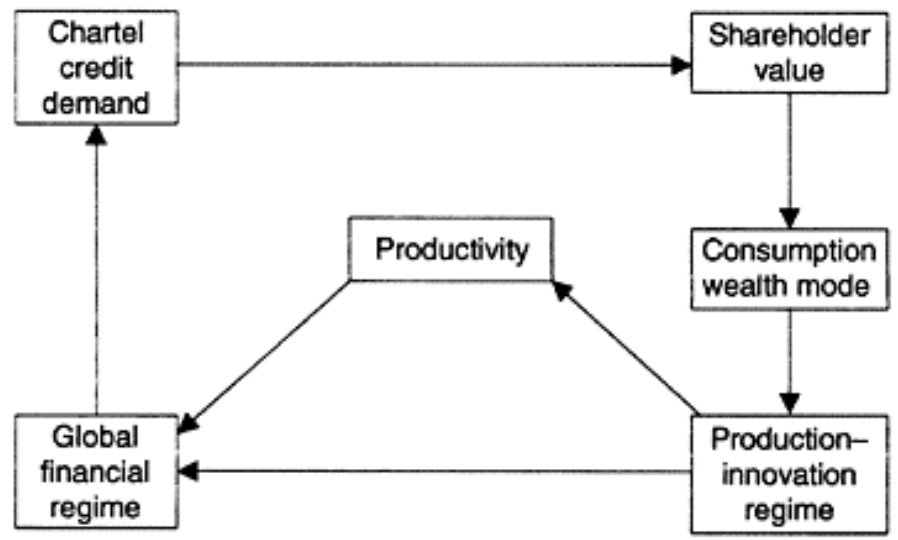

Figure 8.2 The Chartel, finance-led accumulation regime and circuit. 
Productivity supposedly advances as the shareholder system leads to capital inflow to take advantage of equity growth and corporate profit, as the economic system becomes more global in orientation. This then expands credit as the circuit undergoes successive expansions and cumulative motion, or so the argument goes.

Is this finance-led regime promoting long-term economic performance? In other words, are the dynamic structures of the finance system promoting SSA functions of sustainable (1) financial stability, (2) conflict resolution, and (3) productivity, profitability, and adequate service provision at reasonable prices? The objective of the next three sections is to get some answers to these questions. We start with the financial stability function.

\section{SSA function of financial stability}

During the long wave upswing of the 1950s and 1960s, financial instability was relatively low and banking crises absent in the United States and most of the world as system-risk was limited through interest rate and foreign exchange controls and institutional supports (Wolfson 1994a). Banking and financial crises and crashes have, however, been regular occurrences in the United States_and most of the world_-during the 1970-2003 period. Much of this has already been discussed in Chapter 7, so this will necessarily be a brief account here.

The boom of the late 1990s-2000 led to the 2001-2003 high tech and Internet crash of around 80 percent (Nasdaq 2004), an S\&P500 major correction of 50 percent (S\&P 2004), plus recession and low employment generation during recovery from the recession. The late 1990s and early 2000s is the greatest period of financial instability since the early 1980s and potentially since the Great Depression of the 1930s. In this environment, monetary authorities were relying to an increasing degree on confidence levels in the equity market. The equity market transmission mechanism is becoming more critical to US policy (as discussed in Chapter 7) (see Iturriaga 2000; Mishkin 2001). ${ }^{7}$

Evidence demonstrates that there is a negative relationship between market interest rates and equity returns, with bank securities being more interest sensitive than securities of nonfinancial corporations (Madura and Schusenberg 2000). Under the "new financial regime," the Federal Reserve may decide to reduce rates, which is identical to an increase in bond prices. If rates are perceived to be about the lowest they can go-meaning that bond prices are considered to be at or near their highest point - then bond holders will tend to sell bonds in favor of equity. This switch from bonds to equity will result in an increase in equity demand, and hence an increase in equity prices, often financed by an increase in credit. This will raise real wealth, leading to an increase in both consumption and investment demand, which through the multiplier and accelerator will raise GDP, at least in the short term.

Evidence shows that the wealth effect of stock prices on consumption is higher in the United States, because the percentage of households who hold equity (directly or indirectly) is more advanced here than elsewhere in the world, as shown in Chapter 7. A critical question is the extent to which there have been speculative bubbles in the stock market, and the degree to which the bubble crashed during 2000-2004, resulting in a major drop in wealth. If a generalized speculative bubble existed, and then crashed, this 
should have reversed consumer confidence, reduced investment, leading to a slowdown in US domestic demand, and a deep recession.

As discussed in Chapter 7, a positive bubble was likely present before the crash of 1987, during the early 1990s, and during the late 1990s. In 1987 a substantial correction was made; also during 1993-1994; and during 2000-2004. The 2000-2004 decline of the S\&P500 P/E ratio in the order of around 50 percent is very significant in terms of the course of economic activity. It is highly unlikely that financial innovations have been significant enough to increase fundamental values from the historical average $\mathrm{P} / \mathrm{E}$ ratio of around 13.3 to anywhere near more recent high levels.

The pattern of the rise and fall of the Nasdaq-100 Index, an index of share prices for the leading companies in computing hardware, software, telecommunications, newtechnology wholesale and retail trade, and biotechnology, was shown in Chapter 7. It was shown how the speculative bubble in the Nasdaq Index crashed by about 80 percent during the period 2000-2003, wiping out all the gains made since mid-1997. Given that the boom in the late 1990s was, to a large degree, a result of the positive wealth effect of the equity market bubble increasing demand, a major decline in the S\&P500 bubble and a major crash of the Nasdaq-100 bubble reversed this demand expansion. Indeed, the decline in wealth, consumption, and investment and thus real GDP has already been substantial. On an annual basis, the decline in the equity market in the United States during 2000-2004 saw a drop in consumption of about 6 percent of GDP as a result of the Nasdaq crash alone due to a negative wealth effect.

Also, in the wake of the Enron, Worldcom, and Global Crossing crisis, many equity players have lost considerable trust and confidence in "corporate America," leading them to have doubts about official net earnings figures and accounting standards (hence the official revisions of profit data and changes in governance standards for auditing and debt).

A critical problem is the narrow consumption base of the 1990s boom, depending as it did on the wealth effect of equity bubbles and greater debt financing of consumption. The boom of the 1990s was the most consumption-dependent cycle expansion for at least 50 years. Being based on share bubbles, it had little potential to be sustainable. The rising consumption of the working class and the poor during the 1990s was also unsustainable, since it was "accompanied not by rising real incomes for the majority of the population but stagnant wages” (Monthly Review Editors 2000). This major drop in relative income led even the poorest to try at least to "keep up with the Joneses" in relative spending patterns, a factor Veblen would have pointed to, which led to a major increase in debt.

The ratio of total private debt to disposable income changes in a cyclical fashion, rising during business cycle upswings and declining during recession. However, during the instabilities of the 1980s and 1990s it has risen to quite dramatic historic highs: moderate yearly increases from 0.95 (1960) to 1.2 (1980) were followed by more rapid yearly increases to 1.5 (1990) and 1.73 (2000) (Wray 2002). Partly as a result, individual bankruptcies in the United States increased from 3,200 per million 1994 to 5,000 in 1999, even before the stock crash of 2000-2002 (Stavins 2001:17). Individual bankruptcies escalated into 2001 and 2002 by 16 and 19 percent, respectively (Hyde 2002).

Thus, as we commence the new millennium there does not appear to be a sufficient degree of financial stability to moderate uncertainty. The limitations of the wealth effect highlights the lack of stability in the finance-led accumulation regime. Also, the equity 
transmission mechanism used by the Federal Reserve is propelling greater financial instability. One reason for this is the inability of interest rate changes during a business cycle upswing to moderate speculative bubbles as bank equity returns are ten times more sensitive to decreases than increases in official interest rates (Madura and Schnusemberg 2000:435). In other words, the bubble becomes very pronounced leading to a potentially steeper crash, along with wealth destruction. As Fredrich Mishkin (2001:1) said: "targeting asset prices by central banks is likely to lead to worse economic outcomes and might even erode the support for their independence."

\section{SSA function of conflict resolution}

Conflict resolution —in this context—relates to a required balance between the power and remuneration of finance and industry. Both Veblen and SSA scholars recognize the importance of this conflict (see Veblen 1923; Wolfson 1994b: Cypher 1998; O’Hara 2002a): that is between, on the one hand, the productive areas of workmanship, innovation, and productivity, and the financial areas of trading shares, currency, and other securities, on the other. An imbalance between these two areas can adversely affect economic performance such as investment, consumption, and GDP. During the long wave downswing of the 1970s-2000s, the financial system had been deregulated, share value became a dominant force, and the free flow of finance was at its strongest level ever.

To comprehend the changes in the relationship between finance and industry it is necessary to reexamine the Chartel circuit explored in Figure 8.2. The new Chartel system eases the financial constraint of the economy by enabling a greater volume of credit through endogenous finance. The flow of funds is thus not strictly controlled by the central bank, as it prefers to influence interest rates and largely accommodates the financial requirements of the economy. Financial innovations such as securitization, the lowering of reserve requirements, and new liability management practices during the 1970s and 1980s enabled financial institutions to increase the ratio of credit/reserves. The expansion of swaps, futures, and options reduced the apparent risk of increasing credit, and thereby expanded the debt structure of firms. The 1980s and 1990s saw a much greater impact of credit on equity prices than during the 1950s-1970s because there has been a relative increase in the proportion of credit used for purchasing financial assets vis-à-vis real assets. This has led to financial hoarding and to the development of speculative bubbles as part of the normal functioning of the economy.

Three main developments have followed, according to Binswanger (1999). First, there has been a marked drop in the causal link between money/credit and inflation during the 1980s and 1990s. Much of the credit has been used for buying equity, and therefore credit expansion has propelled higher equity prices more than higher prices for investment or consumer goods. This has had an apparently positive effect on the economy by dampening inflationary forces. Second, however, by reducing inflationary pressures, and thereby limiting interest rate rises, this has led to a rapid expansion in the demand for equity, propelling successive speculative bubbles in the economy, as discussed in the previous section of this chapter. These bubbles are not sustainable because fundamental variables, such as long term dividends and expected profitability of industry, fundamentally condition stock prices in a longtime horizon (Hardouvelis 1988). Thus, the 
use of derivates such as options, swaps, and futures has reduced the cost of diversification and leverage, and also increased the relative return for equity relative to industry.

This leads to the critical third point: the changing structure and dynamics of the US financial system since the 1970s has increased the conflict between finance and industry, since the real sector has become a sideshow to the main game of capital gains in the equity market. This has had a negative impact on industry and economic growth, in the longer time horizon, by drawing funds into equity markets rather than promoting innovation, workmanship, and long-term investment in industry (broadly conceived). Lender of last resort facilities and big government may prevent depression, as Minsky (1982) recognized. But the Chartel and finance-led accumulation regime expands the power of finance over industry, heightens uncertainty, adversely affects investment and consumption, and thus increases the depth of periodic recession.

\section{Table 8.1 Granger and $R^{2}$ relation between stock returns and production growth}

\begin{tabular}{lll}
\hline & 1953-1965 & 1984-1995 \\
\hline$H_{0}:$ F-statistic (lags: 3) & 4.23733 & 0.35699 \\
$H_{0}:$ Probability (lags: 3) & 0.00661 & 0.78415 \\
Adjusted $R^{2}$ & 0.11 & 0.00 \\
\hline
\end{tabular}

Source: Adapted from Binswanger (2000:382).

Thus, "economists had no trouble in explaining the (1949-1965) persistent bull market by standard valuation models according to which stock prices are determined by market fundamentals. But the recent (1984-1995) period is more troublesome” as stock returns have no relationship to fundamentals, according to Binswanger (2000:380). Table 8.1 summarizes his main technical findings. Binswanger scrutinized $\mathrm{H}_{0}$, that "Stock returns do not Granger cause production growth." He found, through the " $F$ statistic," that there was a temporal link between the two variables leading from stock prices to production for the 1953-1965 period, but not for the 1984-1995 period. The probability that there was no link was very low during 1953-1965 and high during 1984-1995. $R^{2}$, the squared correlation between observed and fitted values, was 0.11 for 1953-1965 and 0.00 for 1984-1995. Hence his conclusion that, over the past 20 years, "current stock returns do not seem to contain significant information about future real activity as before” (2000:386). He goes on to say that:

A plausible explanation of our results would be the existence of [positive] bubbles or fads, which, if one accepts the explanation, were a persistent phenomenon on the stock market since $1984 \ldots$. . Changes in monetary policy... through changes in nominal interest rates..., may be a potential cause for our finding as there is a lot of evidence that monetary policy exerts large effects on stock returns.... [But,] there is no reason why changes in monetary policy should disturb the relation between real activity and stock returns unless investors are not driven by fundamentals 
or act irrationally on changes in monetary policy, which again, would speak in favor of the existence of speculative bubbles.

(Binswanger 2000:386) ${ }^{9}$

Broadly speaking, then, there was a reasonable link between stock prices and production during the long wave upswing of the 1950s and 1960s. But as long wave downswing evolved into the 1980s and 1990s, stock prices became relatively autonomous from the industrial sector, which increased the inefficiencies of the financial system (Haugen 1999). This autonomy is inextricably linked with the periodic generation and crash of speculative bubbles during the 1980s and 1990s.

This type of behavior has led to a re-thinking of the relationship between stock market development and economic growth. Because of the increasing instability, overreaction, herding, and speculative functioning of equity markets-especially in the United States, and to some degree in other regions, such as Japan and Europe-the 1980s and 1990s into the twenty-first century has seen a de-linking of equity prices from long-term economic growth. The practice of mis-pricing equity has led to the conclusion that equity traders are subject to "irrational expectations" (Nam et al. 2001), and that the common practice of herding-based on little information-leads to "bull markets [being] intrinsically more fragile" and subject to crash (Welch 2000:369). This increasing instability of equity markets of late increases uncertainty and hence "affects economic growth adversely” (Arestis et al. 2001:19). Thus:

[O]ur findings [for the United States] are consistent with the view that bank-based financial systems may be more able to promote long-term growth than capital-market-based ones. Our findings also suggest that stock market volatility had negative real effects in Japan and France. In the case of the United Kingdom stock market volatility seems to have exerted negative effects both on financial development and output.... [Volatility of any kind reflects general economic uncertainty and is, therefore, negatively correlated to real economic activity.

(Arestis et al. 2001:37)

Similar results were gained by Engelbert Stockhammer (2004) who studied the causes of the accumulation slowdown of the last 30 years in the United States, United Kingdom, France, and Germany. He found that during the golden age of the 1950s and 1960s corporate growth was a predominant tendency and that this promoted accumulation and GDP expansion. But as the 1970s progressed through to the 1980s and 1990s shareholder value became more important than growth in the United States, United Kingdom, and France, resulting in a drop in the rate of accumulation. The same did not happen in Germany due to a lack of sharemarket development during the period studied. The increasing trend to "financialization" in the United States, United Kingdom, and France has thus had a negative impact on industry and accumulation, and hence "the reorientation of management priorities along the lines of creating shareholder value, leads to a reduction in the growth rate” (Stockhammer 2004:738).

We thus conclude that the current financial system in the United States-and economies that have been following the United States in the degree of dominance of 
sharemarket value, such as the United Kingdom and France-is worsening the conflict between finance and industry and hence, in this context, is not supporting the formation of a FSSA.

\section{SSA functions of profitability, productivity, and customer satisfaction}

But is the banking sector any more conducive to long-term growth and accumulation? The third requirement of a financial SSA is that it be a viable system of credit provision, financial advice, savings and accumulation for consumers, business, and government. It should fulfill the technical social requirements of finance for the population in a fashion that does not threaten the livelihood of those who use its services and resources. This requires that the banking system engage in continual innovation to support an array of modern services, while at the same time organizing its operations in a suitably prudential fashion and providing sustainable profitability for its banks and institutions so as to minimize the system-effects of crises and crashes. In short, the social functions of finance need to extend beyond stability and conflict resolution to enhance banking system (a) sustained productivity, (b) risk-averse, long-term profitability, and (c) service provision. The objective of this section is to ascertain whether the US banking system enhances these interrelated public goods.

A recurring theme in the literature is that, during the 1980s and 1990s, the US banking system has been thoroughly reorganized, reconstructed, and deregulated. Financial innovations such as EFT, EFTPOS, Internet banking, off balance sheet activities, and the like have transformed the payments system through greater productivity and customer orientation. Low profit, potential bankruptcy, and crises in the industry during the 1980s, and the merger and rationalization movement in the 1990s has led to a much greater level of competition and profitability, as well as a lower level of risk as banks are getting larger, more powerful and better able to diversify their portfolio. The scrapping of interest rate controls, greater liberalization of bank holding companies and the gradual encouragement of a national banking system has supposedly reduced the limits to the market determination of output and employment. The image one gets in much of the literature is of a system getting stronger, more viable, less risky, and more productive.

This image is a myth since, in fact, productivity is in general quite low, the higher profit being in large measure a reflection of a greater risk premium in the 1990s cycle upswing, and customer complaints being at peak levels. First we consider productivity. The literature puts a lot of emphasis on the record of the 1980s, being as it presumably was an indication of the first-order effects of deregulation and new electronic forms of technology. The evidence is overwhelming that the productivity record in the 1980s - as a result of deregulation and innovation-was somewhere between negative and minor. Humphrey found, in a whole series of studies (e.g. Humphrey 1991), that there was minimal productivity because of a shift from zero-interest demand deposits to higher interest cost purchased funds, greater competition from institutions such as money market mutual funds, and an increase in the number of bank branches (for a time).

Ivan Alam (2001) made a more detailed temporal and industrial analysis of the decade and found that there was a slight drop in overall productivity for the banking sector as a whole during the 1980s. His detailed analysis found that most of the productivity gains occurred during 1983-1984, and that State Banks were more productive than Limit 
Banks, which were in turn more productive than Unit Banks. The aggregate results are summarized in Table 8.2, where the Malmquist Index is examined. With this index, above unity (i.e. above 1) represents an increase in productivity, while below unity is a decline in productivity.

Table 8.2 Malmquist productivity index for all US banks, 1980-1989

\begin{tabular}{lcccccccccc}
\hline & $\begin{array}{c}1980 / \\
1981\end{array}$ & $\begin{array}{c}1981 / \\
1982\end{array}$ & $\begin{array}{c}19821 \\
1983\end{array}$ & $\begin{array}{c}1983 / \\
1984\end{array}$ & $\begin{array}{c}19841 \\
1985\end{array}$ & $\begin{array}{c}1985 / \\
1986\end{array}$ & $\begin{array}{c}1986 / \\
1987\end{array}$ & $\begin{array}{c}1987 / \\
1988\end{array}$ & $\begin{array}{c}1988 / \\
1989\end{array}$ \\
\hline Index & 0.948 & 0.968 & 0.975 & 1.107 & 0.927 & 0.991 & 1.039 & 1.029 & 1.009 \\
\hline
\end{tabular}

Source: Adapted from Alam (2001:133).

The results are fairly clear: during the majority of the years productivity declined, by 5.2 percent (1980/1981), 3.2 percent (1981/1982), 2.5 percent (1982/1983), 7.3 percent (1984/1985), and 0.9 percent (1985/1986), while, during the minority of years, productivity increased, by a large amount in only one year: 10.1 percent (1983/1984); and by a far smaller amount during three years: 0.4 percent (1986/1987), 0.3 percent (1987/1988), and 0.1 percent (1988/1989). As Alam concluded:

The average bank did not move closer to the frontier: the measured changes in productivity are due almost entirely to shifts in technology rather than changes in efficiency. The lack of dramatic increases in terms of efficiency may be explained by the fact that, by the 1980s, banks already faced significant competition from other financial institutions [such as]...money market mutual funds.... [B]y grouping [all banks] together the productivity effects become muted: the ALL grouping indicates productivity regress of approximately 1 percent for the decade[.]

(2001:136)

What about evidence for the 1990s? Kevin Stiroh (2000) argues that it is critical to look at the record for bank holding companies, rather than just individual banks. Most of the literature ignores bank holding companies, concentrating instead on individual banks. This gives a misleading perspective of the banking sector because, especially in the late 1980s and into the 1990s, legislative and industrial trends support the increasing dominance of these holding companies. A bank holding company (BHC) is usually a nonbank corporation that controls at least one bank (Ladenson 1992) - usually many more than one-and now BHCs are the "dominant form of bank ownership.” In 1997, for instance, "67\% of all FDIC-insured assets were held by multi-bank BHCs; single-bank BHCs held an additional 16\%; and independent bank and thrift institutions held the remaining 17\%” (Stiroh 2000:1707).

It is primarily through BHCs that the current (moderate) trend toward a national banking system is being developed in the United States. Hence, BHC productivity is considered the best measure, details of which are shown in Table 8.3. The evidence presented by Stiroh shows overall that average yearly total factor productivity for BHCs 
grew a disappointing 0.45 percent during 1992-1997, compared with a similarly disappointing 0.8 percent for manufacturing (O’Hara 2003).

Table 8.3 Productivity growth of the US BHCs, 1992-1997 (business loans, consumer loans, securities, and off-balance sheet items)

\begin{tabular}{lrrrrrrrr}
\hline Type of data & 1992 & 1993 & 1994 & 1995 & 1996 & 1997 & Mean \\
\hline Pooled data & 0.22 & 0.59 & 0.62 & 0.29 & 0.45 & 0.50 & 0.44 \\
Fixed data & -0.43 & 0.13 & 0.45 & 0.52 & 0.89 & 1.21 & 0.46 \\
\hline
\end{tabular}

Source: Adapted from Stiroh (2000:1722).

Table 8.4 Rate of return on assets "persistence” for US banks, 1971-1997

\begin{tabular}{lrrrrrrr}
\hline & \multicolumn{1}{c}{1971} & \multicolumn{1}{c}{1976} & \multicolumn{1}{c}{1981} & \multicolumn{1}{c}{1986} & 1990 & 1996 & \multicolumn{1}{c}{1997} \\
\hline Winning & 7.23 & 9.93 & 9.99 & 12.42 & 11.83 & 16.30 & 13.34 \\
Losing & 8.69 & 12.86 & 7.29 & 6.92 & 10.28 & 11.44 & 13.94 \\
Total & 2.87 & 3.61 & 3.56 & 3.41 & 3.61 & 4.36 & 4.25 \\
\hline
\end{tabular}

Source: Adapted from Berger et al. (2000:1213).

He concluded that:

These results suggest that significant inefficiencies existed in the US commercial banking industry in the 1990s.... [R] oughly $10 \%$ of costs were due to inefficiency and $30-40 \%$ of potential profits were missed. Moreover, efficiency does not significantly increase with bank size as one might expect if economies of scale are an important determinant of success.... [T] hese results indicate substantial inefficiency during the 1990s, especially in regard to profits.

(Stiroh 2000:1742-1743)

Despite the profit inefficiencies, a number of studies have reported greater profitability for the commercial banking sector during the 1990s, with peaks being reached in 1999 after which net worth declined (Bassett and Zakrajsek 2001). However, further investigation reveals not only that there was much profit inefficiency-as argued by Stiroh, earlier-but also that much of the profitability that did exist was a result of the boom in the business cycle, when there was an increase in the variance of profitability, or greater risk. For instance, Allen Berger et al. (2000) illustrate that the 1990s was quite unique in that there was a greater "persistence" of bank rates of return during this decade, compared with the 1970s and 1980s. Bank-sector profit persistence is defined as "the tendency for members of a [banking] group to perform above or below a benchmark (i.e. 
to "win" or "lose”) on a consistent basis" (Berger et al. 2000:1208). The evidence for such persistence is summarized in Table 8.4.

This shows that both winning and losing profit persistence increased markedly during the 1990s, compared with the 1980s, and more so than the 1970s. It also shows that total and winning persistence was greater in the 1990s than during the 1970s and 1980s, whereas losing persistence was far greater in the 1990s than the 1980s, and somewhat higher than the 1970s. Berger et al. argue that winning and losing persistence increased especially during the boom of the late 1990s and that macroeconomic conditions have influenced such persistence. ${ }^{10}$

The main result of their study is that the persistently high and low rates of return during the 1990s - an increase in the variance of returns - is equivalent to a higher degree of risk associated with banking in the 1990s. As they say:

[I]t appears that an increase in persistence in the boom period [of the 1990s] was due in part to banks with riskier positions on the risk/return frontier benefitting from the extraordinarily protracted economic expansion. ... [Fluctuations in persistence measures may [thus] be linked to business cycle fluctuations.... [S]harp declines in the total persistence estimates...appear to foreshadow declines in real economic activity. In favorable times, we expect safe banks to have very low returns relative to the industry,... and to have relatively low performance volatility.... This is precisely what we found. Therefore, the estimates presented suggest that differences in risks across banks continue to generate persistence.

(Berger et al. 2000:1214, 1230)

They isolate high growth in "off balance sheet activities"-such as options, swaps, futures - in the order of 10-13 percent per annum during the boom, as being of particular importance to the greater risk of many banks during the 1990s. This implies in general that the 1990s profit expansion was not related to fundamentals but was a transitory phenomenon.

In an environment of low productivity and high risk, how have consumers fared in the 1990s? US banks are on average still relatively small compared with other nations, with a smaller (but increasing) number of branches per GDP and assets per bank. In the 1995 sample studied by Jaffee and Levonian (2001), only Iceland and Finland have fewer assets per bank, and only Japan a smaller ratio of branches to GDP, compared with the United States. However, through deregulation, payment system innovation, mergers, and failures, the number of independent banking organizations has declined in the United States from 9,500 (1989) to 6,800 (1999); that is, including bank holding companies and independent banks with no holding company (FRS 2000:48). The top ten banks in the United States held 26 percent of banking assets in 1989, increasing to 50 percent in 1999, while the top 50 banks held 54 percent of such assets in 1989, increasing to 75 percent in 1999 (DeFarrari and Palmer 2000:48). These percentage figures are still relatively small compared with other nations, but the trend is increasing, and in terms of absolute number of clients per bank, the figure is relatively high.

However, there seems to be a widespread dissatisfaction with banks by households, as branches have closed, service quality declined, and fees increased. This trend is not just 
evident in the United States. Table 8.5 outlines some of the changes in fees in recent years for all banks.

Table 8.5 Percentage change in US bank fees, 1994-1999

\begin{tabular}{|c|c|c|c|c|c|c|c|}
\hline & $\begin{array}{l}\text { Check } \\
\text { a/c (fee } \\
\text { only, no } \\
\text { interest) }\end{array}$ & $\begin{array}{l}\text { Check } \\
\text { a/c } \\
\text { (NOW } \\
\text { a/c, fee } \\
\text { and } \\
\text { interest) }\end{array}$ & $\begin{array}{l}\text { NSF } \\
\text { checks }\end{array}$ & Overdrafts & $\begin{array}{l}\text { Savings } \\
\text { passports }\end{array}$ & $\begin{array}{l}\text { ATMs } \\
\text { (withdrawals) }\end{array}$ & $\begin{array}{l}\text { ATMs } \\
\text { (deposits) }\end{array}$ \\
\hline Fee $[\mathrm{F}]^{\mathrm{a}}$ & $17.8^{*}$ & $34.8 *$ & 15.5 & 17.0 & $31.3^{*}$ & 23.2 & 38.5 \\
\hline $\begin{array}{l}\text { Inflation } \\
{[\mathrm{P}]^{\mathrm{b}}}\end{array}$ & 14.5 & 14.5 & 14.5 & 14.5 & 14.5 & 14.5 & 14.5 \\
\hline F-P & 3.3 & 20.3 & 1.0 & 2.5 & 16.8 & 8.7 & 23.0 \\
\hline
\end{tabular}

Source: Adapted from Hannon (2001, various pages) ${ }^{\mathrm{a}}$; USDL (2004) ${ }^{\mathrm{b}}$.

Note

* Fee for low balance.

The general pattern at banks is for fees to have increased at a rate far greater than inflation, especially for the most important accounts and transactions. The largest increases, in order of significance, occurred for deposits at automatic teller machines (ATMs), NOW interest check accounts, savings passports, ATM withdrawals, no-interest check accounts, overdrafts, and NSF checks. Generally, there is a positive relationship between fees and bank size. Savings association fees have increased somewhat less than that of banks, but still usually greater than the rate of inflation. Hence the attitude, which is widespread, that banks are getting "big, greedy, and impersonal."

It seems clear, then, that the third requirement of a financial SSA has not been satisfied. The US banking system has insufficient productivity, unsustainable cyclical profit levels with higher risk, and insufficient customer focus. It is thus unlikely that the banking system is at present contributing sufficiently to the provision of enough public goods to promote long wave upswing. ${ }^{11}$

\section{Conclusion}

The evidence supports the notion that long wave upswing is not yet in sight, at least as far as the financial relationships and processes are concerned. The finance-led accumulation regime does not promote a sustainable money circuit dynamic due to the high levels of instability, major conflict between industry and finance, and insufficient productivity, risky profitability and a low level of customer focus. The high levels of instability are related to a Chartel system characterized by endogenous funds, capital inflow, and speculative bubbles, producing a wealth effect that was unsustainable in the late 1990s as the equity market bubble crashed leading to major dislocation and bankruptcy. The 
conflict between industry and finance relates to the change from the 1950s and 1960s, when there was a close link between equity market growth and production growth, to the 1980s and 1990s when this link has ceased to operate. And the declining productivity, unsustainable profitability, and low level of customer focus relate to a banking sector that has become more risky, profit inefficient, and charging consumers high fees with a low level of personal service.

The conclusions point to a persistent inability of the financial system to satisfy the system-requirements or public goods necessary for a well functioning financial regime that encourages long-term economic performance. Hence, the financial system does not support long wave upswing. It supports business cycle upswings leading to periodic deep recessions and financial instability, such as developments in the early-2000s. Unless adversity becomes entrenched, it is likely that a cycle upswing will develop by middecade (2005), and the real test of whether long wave upswing emerges will be how deep the recession and financial instability at the end of the first decade of the twenty-first century will be. If suitable policies are put into place in the meantime then a financial social structure of accumulation may evolve that prevents deep recession plus major bubble growth and bust through the first such decade. But such developments are not in place at the moment.

\section{Notes}

1 I wish to thank Mat Forstater, Jim Devine, Chris Rude, and Sven Larson for comments, without implicating them in the analysis or conclusions. This chapter was presented at the January 2002 meetings of the Union for Radical Political Economics (as part of the ASSA), Atlanta, Georgia, USA. For a very early and much shorter version of this chapter, see Phillip Anthony O'Hara, “A New Financial Social Structure of Accumulation in the United States for Long Wave Upswing?,” Review of Radical Political Economics, Volume 34, Number 3, Summer 2002, pp. 295-301 (O’Hara 2002b).

2 More specifically, for the third of these conditions - profitability-we include performance in general, and also (i) sustainable profitability, (ii) productivity, and (iii) customer satisfaction.

3 Numerous studies have been undertaken into these individual as well as macro (or global) SSAs (social structures of accumulation). For the individual SSAs, see the more recent studies of Wolfson (1994a) and Guttmann (2001) on the financial SSA. Much of the work on the regulation approach is of relevance here as well, such as the five volumes edited by Jessop (2001).

4 Wolfson (1994a) delineates the three main criteria for a SSA to be sufficient: stability, conflict resolution, and profitability. This current chapter extends the third criteria from simply profit to include productivity and consumer orientation. Financial productivity and consumer concerns are considered to be important dimensions that are required for a new FSSA, particularly for the banking sector. Also, Wolfson examines the domestic and international aspects of the current financial system, whereas this chapter underplays somewhat the international dimensions because these are the subject of Chapter 6 .

5 There are many global contradictions that require conflict resolution institutions to moderate trade instability through the circuit. The conflicts over trade issues arise from different levels, such as from (a) competition between capitals, (b) conflict between nation states, (c) capital-labor relations, (d) between production and reproduction (system) functions, and (e) between private interests and the ecological environment. These multiple sources of conflict all require the operation of various institutional support networks, accords, forms of trust, 
and cooperation to resolve some of the more immediate limits to long-term reproduction (see Yeung 1998).

6 It could be argued that, while neoliberalism has been strong over the past 20 years, nevertheless there have been some challenges to the neoliberal policies and in the 1990s onwards prudential policies have been an important part of the governance structures of national and global capital. Such prudential policies seek to establish capital adequacy requirements in order to reduce the potential for greater instability. However, as is argued in this chapter, on balance, factors that enhance instability have been more critical in practice.

7 This mechanism may be supplemented by the workings of the credit and other monetary policy channels. There are numerous transmission mechanisms operating at present, although many have been shown to have little long-term policy effectiveness, at least in the United States. The newest one to be analyzed is the equity mechanism, which appears to be conspicuous in the United States (and other nations dominated by equity prices). In bankbased mechanisms, the credit route seems to be more effective. Other mechanisms include the exchange rate and interest elasticity route. Iturriaga (2000) provides a good summary of these mechanisms, and an empirical test of the credit link. Mishkin (2001) provides a good critical analysis of asset price mechanisms.

8 Mishkin goes on to say that there are serious flaws with monetary authorities using the asset price mechanism because: "First[,]...it is very hard for monetary authorities to have [good] information and predictive ability" about the bubbles.

[S]econd[,]...[m]ost fluctuations in stock prices occur for reasons unrelated to monetary policy, either reflecting real fundamentals or animal spirits.... An additional problem with targeting asset prices is that it may weaken support for a central bank because it looks like it is trying to control too many elements of the economy.

(2001:17-18)

9 Binswanger explores two other alternatives to speculative bubbles as the main reason for the de-link between stock prices and production: the influence of monetary policy and the globalization trend. In general, he believes that neither of these alternatives should break the stock price-production link. Hence the reason he supports speculative bubbles as the main culprit. On monetary policy he concludes that

there is no reason why changes in monetary policy should disturb the relation between real activity and stock returns unless investors are not driven by fundamentals or act irrationally on changes in monetary policy, which again, would speak in favour of the existence of speculative bubbles

(2000:386)

\section{And on globalization he says:}

A further hypothesis that may explain the breakdown of the relation between stock returns and subsequent real activity would be that globalization of the financial markets causes expectations of future cash flows to be less related to domestic markets...more related to the expected development of the world markets where the big transnational corporations, whose share prices dominate stock indices, sell most of 
their products.... However, it is difficult to associate increasing globalization with the changes in the relations between real activity and stock returns especially during the 1980s.

(2000:386)

10 Geographic limits on the expansion of branches and national banking, it is argued, had little impact on the results.

11 Broaddus (2000) — President of the Federal Reserve Bank of Richmond, Virginia —notices these consumer "anxieties" of diminished service, high fees, and increased bureaucracy in the (especially larger) banks. He recognizes that established banking relationships have been disrupted, consumers have suffered from higher fees, and that there are greater levels of standardization of services. However, he is optimistic that many of these costs associated with mergers and consolidation will be only transitional in nature. For instance, he believes that the newer community banks are an appropriate "antidote" to the diminished service, that the higher fees are simply a process of "unbundling" of services, and that the greater standardization of services will be balanced by the greater presence of community banks in the future. It will be interesting to see whether this in fact occurs.

\section{References}

Aglietta, Michel. (2000) "Shareholder Value and Corporate Governance: Some Tricky Questions," Economy and Society, Volume 29, Number 1, pp. 146-159.

Alam, I. (2001) “A Non-parametric Approach for Assessing Productivity Dynamics of Large U.S. Banks,” Journal of Money, Credit, and Banking, Volume 33, Number 1, pp. 121-139.

Arestis, Philip and Alfred S.Eichner. (1988) "The Post-Keynesian and Institutionalist Theory of Money and Credit,” Journal of Economic Issues, Volume 22, Number 4, pp. 1003-1033.

Arestis, Philip, P.Demetriades, and K.Luintel. (2001) "Financial Development and Economic Growth: The Role of Stock Markets,” Journal of Money, Credit, and Banking, Volume 107, Number 442, pp. 16-41.

Bassett, W.F. and E.Zakrajsek. (2001) "Profits and Balance Sheet Developments at U.S. Commercial Banks in 2000,” Federal Reserve Bulletin, June, pp. 367-393.

Berger, A.N., S.D.Bonine, D.M.Cotitz, and D.Hancock. (2000) "Why are Bank Profits so Persistent? The Role of Product Market Competition, Informational Opacity, and Regional/Macroeconomic Shocks,” Journal of Banking and Finance, Volume 24, Number 7, pp. 1203-1235.

Binswanger, Mathias. (1999) Stock Markets, Speculative Bubbles and Economic Growth: New Dimensions in the Co-evolution of Real and Financial Markets, Cheltenham, UK and Northampton, MA: Edward Elgar.

Binswanger, Mathias. (2000) "Stock Returns and Real Activity: Is There Still a Connection?” Applied Financial Economics, Volume 10, August, pp. 379-388.

Boyer, Robert. (2000) "Is a Finance-Led Growth Regime a Viable Alternative to Fordism? A Preliminary Analysis,” Economy and Society, Volume 29, Number 1, pp. 111-145.

Broaddus, J.A. (2000) “The Bank Merger Wave: Causes and Consequences,” Economic Quarterly (Federal Reserve Bank of Richmond), September, pp. 1-11.

Coggins, Bruce. (1998) Does Financial Deregulation Work? A Critique of Free Market Approaches, Cheltenham, UK and Northampton, MA: Edward Elgar.

Cooper, R.N. and J.S.Little. (2001) “Does Japan Offer Any Lessons for the United States?,” New England Economic Review, September, pp. 32-56.

Cypher, James M. (1998) "Financial Dominance in the US Economy: the Increased Relevance of Veblen's Analysis in a Post-Keynesian Structure,” in S.Fayazmanech and M.R.Tool (eds), 
Institutionalist Theory and Applications: Essays in Honor of Paul Dale Bush, Volume 2, Cheltenham, UK and Northampton, MA: Edward Elgar.

DeFarrari, L.M. and D.E.Palmer. (2000) "Supervision of Large Complex Banking Organizations,” Federal Reserve Bulletin, February, pp. 47-59.

Dillard, Dudley. (1987) "Money as an Institution of Capitalism,” Journal of Economic Issues, Volume 21, Number 4, pp. 1623-1647.

FRS (Federal Reserve System). (2000) Federal Reserve Bulletin, April.

Goodhart, Charles A.E. (2000) “Can Central Banking Survive the IT Revolution?” International Finance, Volume 3, Number 2, pp. 189-209.

Guttman, Robert. (2001) “Social Structure of Accumulation: Financial,” in P.A.O’Hara (ed.), Encyclopedia of Political Economy, Volume 2, London and New York: Routledge: 1061-1063. Paper edition.

Hannan, T.H. (2001) “Retail Fees at Depository Institutions, 1994-99,” Federal Reserve Bulletin, January, pp. 2-11.

Hardouvelis, G.A. (1988) "Evidence on Stock Market Speculative Bubbles: Japan, the United States, and Great Britain,” Federal Reserve Bank of New York, Quarterly Review (Federal Reserve Bank of New York), Summer, pp. 4-16.

Haugen, R.A. (1999) The New Finance: The Case Against Efficient Markets, Englewood Cliffs, NJ: Prentice-Hall.

Humphrey, David B. (1991) "Productivity in Banking and Effects from Deregulation,” Economic Review (Federal Reserve Bank of Richmond), March/April, pp. 16-28.

Humphrey, David B., Moshe Kim, and Bent Vale. (2000) "Realizing the Gains from Electronic Payments: Costs, Pricing and Payment Choice,” Journal of Money, Credit and Banking, Volume 33, Number 2, pp. 216-234.

Hyde, P. (2002) “Bankruptcies,” The Timesizing Wire. http://www.timesizing.com/\%20lbankrupt.htm (accessed December 6, 2002).

IMF. (2001) World Economic Outlook, May 2001: Fiscal Policy and Macroeconomic Stability, Geneva: International Monetary Fund

Iturriaga, Feliz J. (2000) "More on the Credit Channel of Monetary Policy Transmission: An International Comparison,” Applied Financial Economics, Volume 10, Number 4, pp. 423-434.

Jaffee, Dwigh and Mark Lenonian. (2001) "The Structure of Banking Systems in Developed and Transitional Economies,” European Financial Management, Volume 7. Number 2, pp. 161182.

Jessop, Bob. (ed.) (2001) Regulation Theory and the Crises of Capitalism. 5 vols, Cheltenham, UK: Edward Elgar.

Kadmos, George Anthony and Phillip Anthony O’Hara. (2000) "The Taxes-Drive-Money and Employer of Last Resort Approach to Government Policy,” Journal of Economic and Social Policy, Volume 5, Number 1, pp. 1-22.

Lacker, J.M. and J.A.Weinberg. (1998) “Can the Fed be a Payment System Innovator?,” Economic Quarterly (Federal Reserve Bank of Richmond), Number 2, pp. 1-25.

Ladenson, M.L. (1992) "Bank Holding Companies," in P.Newman, M.Milgate and J.Eatwell (eds), The New Palgrave Dictionary of Money and Finance, London: Macmillan.

Madura, Jeff and Oliver Schnusenberg. (2000) "Effects of Federal Reserve Policies on Bank Equity Returns,” Journal of Financial Research, Volume 23, Number 4, pp. 421-447.

Minsky, Hyman P. (1882) Can "It” Happen Again? Essays on Instability and Finance, Armonk, NY: M.E. Sharpe.

Mishkin, Frederick S. (2001) "The Transmission Mechanism and the Role of Asset Prices in Monetary Policy,” NBER Working Paper 8617, December, New York, National Bureau of Economic Research.

Monthly Review Editors. (2000) "Working Class Households and the Burden of the Debt," Monthly Review, Volume 52, Number 1, pp. 1-8. 
Nam, Kiseok, Chong Pyun, and Stephen Avard. (2001) “Asymmetric Reverting Behavior of Shorthorizon Stock Returns: An Evidence of Stock Market Overreaction,” Journal of Banking and Finance, Volume 25, Number 4, pp. 807-827.

Nasdaq. (2004) Nasdaq-100 Index Data. October 1. http://dynamic.nasdaq.com/\%20dynamic/nasdaq100_activity.stm

O’Hara, Phillip Anthony. (2002a) “The Contemporary Relevance of Thorstein Veblen’s Institutional-Evolutionary Political Economy,” History of Economics Review, Number 35, Winter, pp. 78-103.

O’Hara, Phillip Anthony. (2002b) “A New Financial Social Structure of Accumulation for Long Wave Upswing in the United States?,” Review of Radical Political Economics, Volume 34, Number 3, pp. 342-348.

O’Hara, Phillip Anthony. (2003) "Recent Changes to the IMF, WTO and FSP: An Emerging Global Monetary-Trade-Production Social Structure of Accumulation for Long Wave Upswing?” Review of International Political Economy, Volume 10, Number 3, pp. 481-519.

O’Hara, Phillip Anthony. (2004) "Viability of National Government Policies in a Global Political Economy,” in P.A.O’Hara (ed.), Global Political Economy and the Wealth of Nations: Performance, Institutions, Problems and Policies, London and New York: Routledge, pp. 327346.

Palloix, Christian. (1975) “The Internationalization of Capital and the Circuit of Social Capital,” in H.Radice (ed.), International Firms and Modern Imperialism, Harmondsworth: Penguin, pp. 37-62.

Polanyi, Karl. (1944) The Great Transformation, Boston, MA: Beacon Press (1957 edition).

Rochon, Louis-Philippe. (1999) Credit, Money and Production: An Alternative Post-Keynesian Approach. Cheltenham, UK and Northampton, MA: Edward Elgar.

S\&P (Standard \& Poor's). (2004) S\&P United States Indices, October 1. http://\%20www.spglobal.com/earnings.html

Stavins, J. (2001) "Effect of Consumer Characteristics on the Use of Payment Instruments," New England Economic Review, September, pp. 19-31.

Stiroh, Kevin J. (2000) “How Did Bank Holding Companies Prosper in the 1990s?,” Journal of Banking and Finance, Volume 24, Number 11, pp. 1703-1705.

Stockhammer, Engelbert. (2004) "Financialisation and the Slowdown of Accumulation," Cambridge Journal of Economics, Volume 28, Number 5, pp. 719-741.

USDL (US Department of Labor). (2004) Consumer Price Index: US City Average: All Items: 1913-2004, Washington, DC: Bureau of Labor Statistics.

Veblen, Thorstein Bunde. (1923) Absentee Ownership and Business Enterprise in Recent Times: The Case of America, New York: Augustus M.Kelley, 1964.

Weber, Christian E. (2000) "Government Purchases, Government Transfers, and the Post-1970 Slowdown in U.S. Economic Growth,” Contemporary Economic Policy, Volume 18, January, pp. 107-123.

Welch, Ivo. (2000) “Herding among Security Analysts,” Journal of Financial Economics, Volume 58, Number 3, pp. 369-396.

Wincoop, Eric van and K.M.Yi. (2000) “Asia Crisis Postmortem: Where did the Money go and did the United States Benefit?” Economic Policy Review, September, pp. 51-70.

Wolfson, Martin H. (1994a) “The Financial System and the Social Structure of Accumulation,” in D.M.Kotz, T.McDonough, and M.Reich (eds), Social Structures of Accumulation: The Political Economy of Growth and Crisis, Cambridge: Cambridge University Press.

Wolfson, Martin H. (1994b) Financial Crises: Understanding the Postwar U.S. Experience, Second Edition, Armonk, NY and London: M.E. Sharpe.

Wray, L.Randall. (1998) Understanding Modern Money: The Key to Full Employment and Price Stability, Cheltenham, UK and Northampton, MA: Edward Elgar.

Wray, L.Randall. (2002) "What Happened to Goldilocks? A Minskian Framework,” Journal of Economic Issues, Volume 26, Number 2, pp. 383-391. 
Yeung, Henry. (1998) Transnational Corporations and Business Networks, New York and London: Routledge.

\section{Further reading}

Allen, F. and A.Santomero. (2001) “What Do Financial Intermediaries Do?,” Journal of Banking and Finance, Volume 25, Number 2, pp. 271-294.

Baker, Dean. (2000) “The Supply-Side Effect of a Stock Market Crash,” Challenge, May, pp. 107117.

BEA (Bureau of Economic Analysis). (2001) “GDP and Other Major NIPA Series: 1929-2001:1,” Survey of Current Business, August,

http://www.bea.doc.gov/bea/\%20ARTICLES/NATIONAL/NIPA/2000/0800gdp.pdf, pp. 3-4.

Cetorelli, N. and M.Gambera. (2001) "Banking Market Structure, Financial Dependence and Growth: International Evidence from Industry Data,” The Journal of Finance, Volume 56, Number 2, pp. 617-648.

Conference Board. (2001) Consumer Confidence Survey, New York: Conference Board.

Dynan, K.E. and M.M.Dean. (2001) “Does Stock Market Wealth Matter for Consumption?” Federal Reserve System, Discussion Paper Series, May, p. 44.

Federal Reserve Bank of Cleveland. (2001) "Money and Financial Markets,” Economic Trends, June 7, p. 4.

FRBNY (Federal Reserve Bank of New York). (2000) "A Nation of Spendthrifts? An Analysis of Trends in Personal and Gross Saving," Current Issues in Economics and Finance, June, pp. 1-6.

Keeton, W.R. (2000) “Are Mergers Responsible for the Surge in New Bank Charters?” Economic Review (Federal Reserve Bank of Kansas City), March, pp. 21-42.

Krainer, John. (2000) “The Separation of Banking and Commerce,” Economic Review (Federal Reserve Board of San Fransisco), Number 1, pp. 15-24.

Miller, Joseph M. (2000) A Tale of the S\&P 500 P/E Ratio over 75 Years, September 21, http://www.gold-eagle.com/editorials_02/jmiller092402pv.html (accessed September 21, 2001).

Moseley, Fred. (1999) "The United States at the Turn of the Century: Entering a New Era of Prosperity?” Capital and Class, Number 67, pp. 25-45.

Nabeshima, N. (2000) “The Financial Mode of Regulation in Japan and its Demise,” in R.Boyer and T.Yamada (eds), Japanese Capitalism in Crisis: A Regulationist Interpretation, London and New York: Routledge.

NBER (National Bureau of Economic Research). (2001) The Business Cycle Peak in March 2001, November, New York, www.nber.org/cycles/november2001/ (accessed December 15, 2001).

Olsen, R.A. (2000) "The Instinctive Mind on Wall Street: Evolution and Investment DecisionMaking,” Journal of Investing, Volume 9, Number 4, pp. 47-54.

Peach, R. and C.Steindel. (2000) "A Nation of Spendthrifts? An Analysis of Trends in Personal and Gross Saving," Current Issues in Economics and Finance (Federal Reserve Bank of New York), October, pp. 1-6.

Stanfield, James Ronald. (1995) Economics, Power and Culture: Essay in the Development of Radical Institutionalism, New York: St. Martins Press.

Stock, J.H. and M.W.Watson. (2001) Stock and Watson Indicator Report, December 7. http://ksghome.haivard.edu/ .Jstock.Academic.Ksg/xri/0106/pr_0106.htm.

Sylvester, David A. (2001) “Stock Slump Eats Into Household Wealth,” SiliconValley.com, March 13. http://www.soliconvalley.com/docs/news/svtop/wealt031401.htm. (accessed August 13, 2001).

USDS (US Department of State). (2002) Global Economic Growth and Statistics, USDS. 
Yaghmaian, Behzad. (1998) "Globalization and the State: The Political Economy of Global Accumulation and Its Emerging Mode of Regulation,” Science and Society, Volume 62, Number 2, pp. 241-265. 


\section{9 \\ A family-community social structure of accumulation?}

\section{Introduction}

Now the third aspect of the US System of Power and Accumulation is scrutinized: the family and community. The question raised is whether a new family-community social structure of accumulation (FCSSA) has emerged in the Unites States to contribute to long wave growth and development through the early decades of the twenty-first century. ${ }^{1}$ Institutions that promote system-functions or public goods are required for sustainable growth and development. Three dimensions of the potential FCSSA institutions are examined in this chapter, within the context of the systemic circuit of social capital: (a) stability within families, (b) trust and association in the community, and (c) the degree of relative equality. Overall, the findings are that a new FCSSA does not currently operate in the United States because the emerging family type is not promoting sufficient stability, trust has diminished to low levels, and structural inequality has continued to rise. These factors have negatively impacted on long-term economic performance through several transmission mechanisms, which are analyzed in the chapter.

Some political economists are reluctant to include family and community relationships and institutions in their studies since they believe that these realms are far removed from capitalist profit and accumulation (e.g. Moseley 1997; Wolff 2001). However, as O’Hara (1995, 2004a) has argued, and as many other scholars have recognized, even capitalist performance is affected by relationships in other spheres. This is because levels of growth and accumulation are affected by the social and institutional environment. As Manuel Castells long ago hypothesized:

Actually, we are not living in the midst of social disruption caused by the economic crisis. On the contrary, we are living in an economic crisis caused by the general process of social disruption in most advanced capitalist societies, which has called into question the structure of social relationships underlying the pattern of capital accumulation.

Indeed, we are still in a period of rapid change into the new millennium, so the question arises as to whether this disruption is continuing to impact negatively on the process of long-term growth and development. The sociocultural realm is critical to the central questions studied in the SSA (social structure of accumulation) approach, even if few scholars have attempted to explore this domain. This chapter, therefore, scrutinizes in some detail the nature of family and community relationships, institutions and changes 
currently in motion in order to assess the degree to which they promote or hinder longterm growth and development. Special reference will be made to the situation in the United States, although many of these changes are occurring in other advanced capitalist nations as well.

The first main section of this chapter summarizes developments occurring in the institutional environment over the past few decades. The second summarizes the importance of the family, trust, and culture within the circuit. The third examines changes in the degree of familial stability and the impact this has on society. The fourth scrutinizes the relationship between trust, association, and democracy. The fifth section studies the nature of structural inequality on the basis of class, race, and gender. The last main section explains these instabilities, declining trust and inequalities as a central contradiction of contemporary capitalism that is impacting negatively on economic performance in several areas.

\section{Changes in the family and community over the past fifty years}

After the Second World War, a new long wave upswing emerged in the global political economy. US capitalism was the center of this new phase of prosperity, and was joined by Western Europe and parts of Oceania. The "Communist" Block was formally in opposition to capitalism, although some Marxists argue that it represented a form of state capitalism (Resnick and Wolff 2002). During the prosperity of the 1950s and 1960s many changes occurred in the dominant institutions of US capitalism. The New Deal was extended to the Welfare State and the New Society Programs of President Johnson. The Fordist system of the capital-labor accord developed so that productivity benefits were divided between capital and labor. A “regulated” financial system provided a source of endogenous funds for industry. The community went through an extended period of optimism as the patriarchal nuclear family, the baby boom mentality, the expansion of suburbia, and a whole new series of domestic technologies were activated. The postwar boom in America saw an expansion of society, economy, and polity that led the charge of a liberal world order.

The family and community played a critical role in the boom. The reproduction of potential labor power was promoted through institutionalized family formation, conception, birth, childhood, upbringing, education, and cultural relations. The family also provided the basic elements of the workforce, including the provision of workers, capitalists, financiers, the reserve army, and potential household workers who were nurtured, fed, clothed, and socialized. The household was also important for the labor process of consumption through shopping, mass consumption, and the coordination of household goods and services. Women provided a "double day" since they increasingly worked in paid employment, but then also did most of the household activities such as cooking, cleaning, and organizing childcare. On balance, they worked longer and harder than men. This was due to the fact that an increasing amount of household production was being provided by the market (which led women into the workforce), while women continued to provide most of the housework as well. Women also sustained male egos and provided the underlying sustenance for the dominant institutions of finance, production, polity, and education (see O’Hara 1995). 
However, many contradictory processes emerged within the postwar SSA to question the continuation of sustained growth and development. The capital-labor accord broke up as technological maturity reduced productivity and declining unemployment increased pressure on real wages and hindered productivity. The Keynesian-welfare state seemed to break down as crowding out and big government adversely affected investment. US hegemony started to decline as the fight against communism faltered in Vietnam and Western Europe emerged economically on a relatively equal footing with the United States. The regulated financial system was upset by a series of changes that led to the dissolution of fixed exchange rates and stable interest rates.

Community standards were changing as the social and sexual revolution questioned established institutions of morality and politics into the 1960s and 1970s. The double day led women to become more dissatisfied with their relationships, and changing standards of social life led to the reemergence of feminism. Divorce doubled through the 1970s to the early 1990s as instability beset the nuclear family and people put more resources into personal and social pursuits such as leisure and work. The expansion of suburbs and transportation combined with rapid social change led to the breakdown in traditional social bonds of community, family, and trust. This expansion of instability, and the questioning of capitalist principles, led to an increase in uncertainty, a lowering of the business cycle floor, and diminishing investment and growth (O’Hara 2000: part C).

The boom of the 1950s-1960s thus led endogenously to the instabilities of the long wave downswing of the 1970s-1990s. The declining socioeconomic performance of the United States since the 1960s has been considerable. Real GDP (gross domestic product) growth, rate of profit, productivity, and inequality have all grown worse from the long wave upswing through to downswing. It is not simply an economic crisis but also a social crisis, as the increase in inequality indicates. Relative inequality has grown considerably during the 1980s and 1990s, which put added pressure on those lower in the distribution of income to emulate the rich through debt-financing and over-consumption, during a difficult era when working conditions and pay rates have deteriorated for the lower classes. To what extent is the social fabric contributing to a continuation of systemic uncertainty and instability? This is the subject of the rest of this chapter.

\section{Systemic circuit of social capital}

This chapter extends the circuit of social capital by introducing family reproduction, trust and association, and cultural attributes into the circuit of relations. As is well known, the simple circuit of money capital commences with the exchange $(\leftrightarrow)$ of money $(M)$ for intermediate commodities (C), such as labor power (LP) and means of production (MOP), followed by the production $(. . P \ldots)$ of surplus value as exchange is interrupted in the "hidden abode of production," resulting in the value of final commodities $\left(C^{\prime}\right)$ being more than their inputs $\left(C^{\prime}>C\right)$, followed by the realization of product and surplus through market sales of "final product" $\left(C^{\prime} \leftrightarrow M^{\prime}\right)$, then the reactivation of money into further rounds of investment $\left(M^{\prime} \rightarrow M\right)$, and so on through several rounds (Marx 1885). 


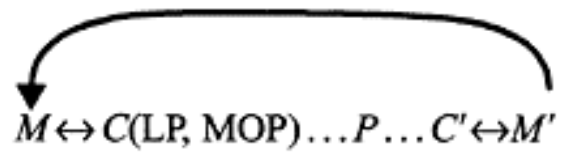

Many scholars have extended the circuit in various ways, such as by the introduction of the world economy, the state, the corporation, and so on (see O'Hara 2001). ${ }^{2}$ We seek to extend the circuit through the introduction of family relations, trust and association, and cultural factors via a more complex circuit, as illustrated in Figure 9.1.

The systemic circuit of social capital illustrates, first, how the reproduction of social and material relations of production and circulation are embedded in a system of "cultural relations," which constitutes the way of life of the community, including the differential norms, mores, and practices of the people. Culture also includes the relations of status, ceremony as well as class, ethnicity and gender, which have regional variations and modes of uneven development. Second, the reproduction of the circuit is embedded in a "global environment" as well as "governance relations" that embody the rules, laws and regulations channeling and directing the practices of individuals, corporations and groups. Third, the circuit is embedded in myriad relations of "trust and association" through global, regional, national, corporate, social, familial, and individual processes.

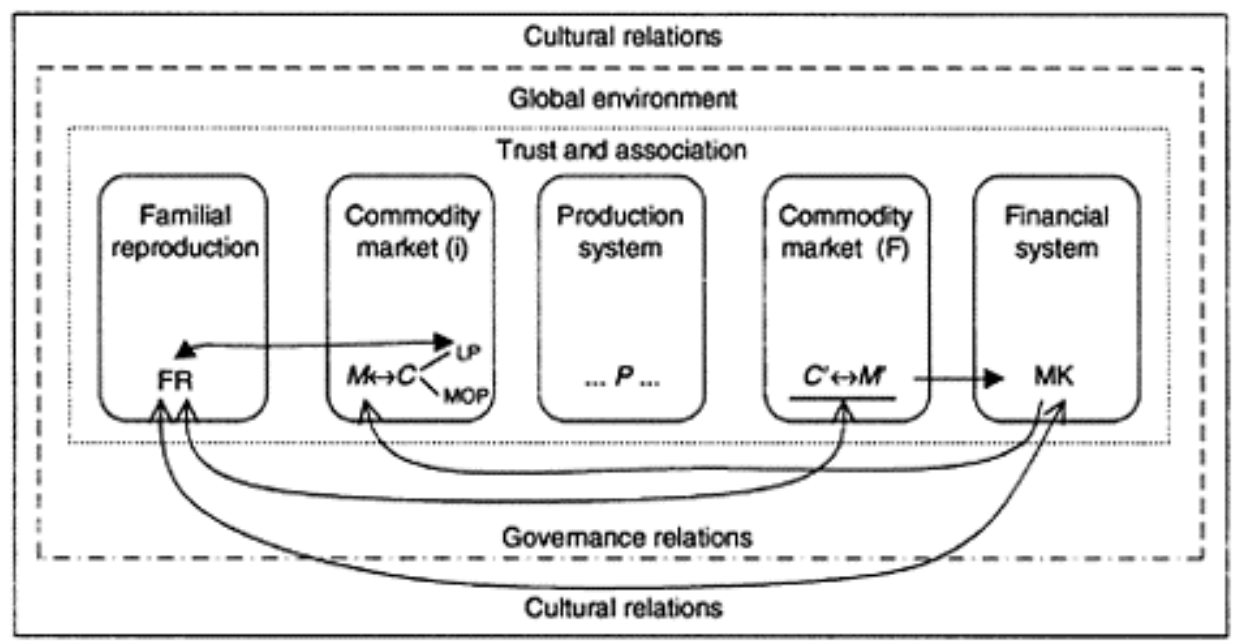

Figure 9.1 Systemic circuit of social capital.

Set within this broad institutional and social environment, the systemic circuit, more narrowly conceived, can be seen to "commence" with a system of "familial reproduction" (FR), which constitutes the roles, practices, and forms of care that are embedded in households, between parents, children, and others. Familial reproduction potentially enables the emergence of a stable environment for people to structure their social practices, and for personality and emotions to evolve. Closely linked to the family are 
relations, friends, and community linkages. The trust and association developed in the family may help the market for intermediate goods and services (i) through enhancing the quality of labor power and conditioning consumption patterns and spending decisions.

The second dynamic structure of the inner circuit includes decisions to exchange money for labor power and means of production in the market for intermediate goods and services. This involves agreements and relationships between capital and labor (or their representatives) in the distributive struggle over shares of national or international income. It also involves structures of competition and pricing in the market for capital goods and material inputs, including machinery, factories, oil, gas, and other raw material. Bottlenecks in this phase of the circuit can have a major negative impact on the reproduction process as a whole. Family relations, trust, association, and culture can also impact on these practices.

The third phase of the inner circuit involves the direct production process, including the valorization of capital, which includes the production of surplus product. This involves all the major relations and processes associated with the ability of capital to subordinate labor and extract surplus labor through an array of technological, organizational, supervisory, and governance structures. However, before the surplus product can become effective, it requires a fourth phase, that of the realization process through "final" market demand (F). Without the ability of capitalism to create sufficient demand - through a combination of consumption, investment, government spending, and/or net exports - the surplus value remains only potential rather than actual. Familial relations and trust are important to this process. And last, for the circuit to be fully reproducible requires that corporate finance $\left(\mathrm{M}^{;}\right)$, or endogenous money and credit through the financial system (MK), be (re)invested into the market for intermediate goods and services as well as through the system of familial reproduction, and so on ad infinitum as the circuit becomes reproduced through varying turnovers of capital.

The circuit can be shown in shorthand form in Figure 9.2. The circuit is a critical methodological tool with which to examine the dynamic processes whereby SSAs are formed and developed. The dominant potential SSAs—as outlined in the circuit-include the family, capital-labor relations, corporate relations of competition and organization, the financial system, governance, and the global environment. This chapter examines the question of the possible formation of a family-community SSA. More specifically, this chapter scrutinizes in some detail the extent to which certain parts of the circuit not usually studied - the process of familial reproduction, trust and association, as well as cultural relations - can potentially enhance the circuit as a whole, and hence the macro (or global) SSA. 


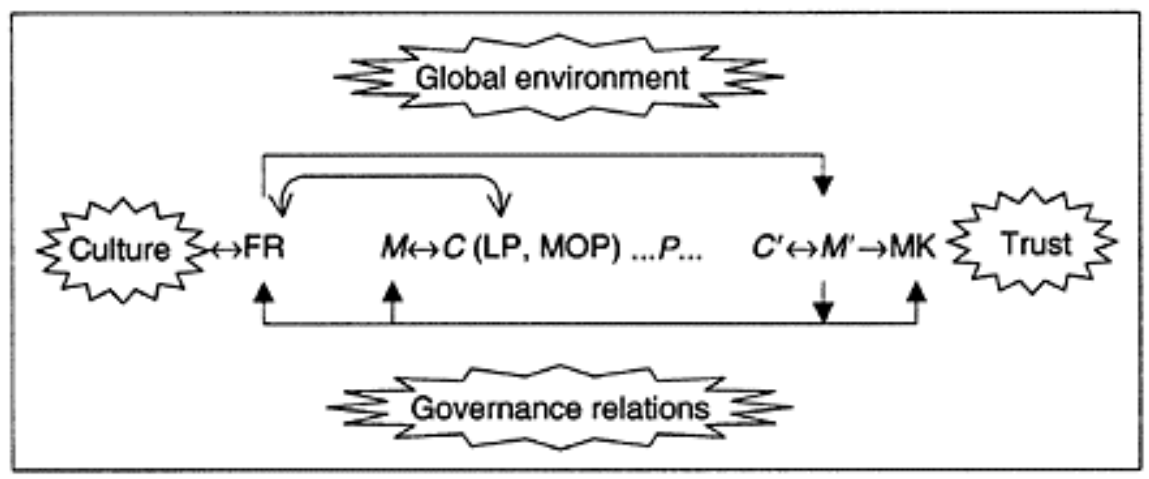

Figure 9.2 Simplified systemic circuit of social capital.

Note $\bigcirc=$ Indicates multiple direction and influence within the SCSC.

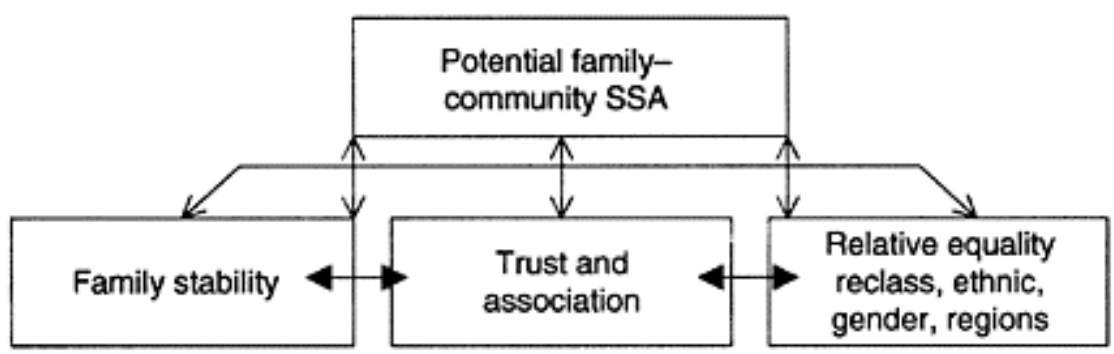

Figure 9.3 Role of familial, social, and cultural factors in FCSSA formation.

We thus deal with three interrelated issues. The first is the degree of development of familial stability in the United States, which may provide a basis for the provision of high quality labor power, communication, emotional bonding, and conflict resolution. The second is the degree of trust and connected association that may reduce transaction costs, enhance democracy, and promote human sociality. And the third is the degree of social, class, and ethnic equality, which may impact positively on the ability of people to utilize their productive abilities more proactively. These three dimensions are illustrated in Figure 9.3.

Taken together, these three dimensions should enable us to ascertain the degree to which a new FCSSA has emerged in the United States to promote long-term growth and development into the early years of the twenty-first century. There is a reciprocal relationship between the main factors in the development of an FCSSA. There are also inherent contradictions in motion that may prevent FCSSA formation and cause potential disruption even if an FCSSA is well formed. Below we examine the three dimensions of 
the potential FCSSA and the contradictions that may be inhibiting an FCSSA from emerging.

\section{Familial reproduction and stability in the 1950s-2000s}

We turn first to the question of familial stability. In the postwar era of the 1950s and 1960s, evidence supports the notion that the stability of the patriarchal nuclear family did help to embed economy in society by promoting some degree of communication, integration, and sociality in the structuring of family and social practices. This stability enabled family members to pursue certain objectives, such as eating a wholesome meal, getting up in time to go to work, and having some degree of emotional satisfaction. It also, for a time, promoted the ideal of "family bliss," employment stability, and social inclusion without challenging the ethos of work, consumption, and material life. To some degree these relationships broke down in the 1970s, 1980s, and 1990s as divorce rose, geographic mobility increased, and greater complexity emerged in socioeconomic life. The 1970s-1990s were thus decades of greater challenges when individuals were under more threat of losing their job, having a family breakdown, and changing friends and workplaces.

What is the record of potential stability and certainty of family life? The figures for divorce, single occupant households, cohabitation, and related factors are shown in Table 9.1. It is true that the rate of divorce (per 1,000 adults) experienced a sudden and continual rise, especially during the 1960s-1980s, from 2.2

Table 9.1 Proxies for (un)familial (in)stability: the United States, 1950-2000

\begin{tabular}{|c|c|c|c|c|c|c|}
\hline 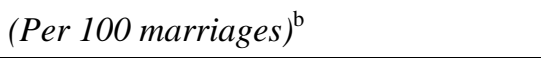 & 1950 & 1960 & 1970 & 1980 & 1990 & 2000 \\
\hline Divorce rate (annual, per 1,000 adults) ${ }^{\mathrm{a}}$ & 2.6 & 2.2 & 3.5 & 5.0 & 4.7 & 4.1 \\
\hline Divorce rate (per 100 marriages) ${ }^{b}$ & 23 & 26 & 33 & 50 & 48 & $\begin{array}{r}51 \\
(1998)\end{array}$ \\
\hline $\begin{array}{l}\text { Population of divorced people } \\
\text { (cumulative, per } 1,000 \text { adults) }^{c}\end{array}$ & & & 3.2 & 6.2 & 8.3 & 9.9 \\
\hline $\begin{array}{l}\text { Family decline "most important problem" } \\
\text { (\% of population })^{\mathrm{d}}\end{array}$ & & & $\begin{array}{r}1.5 \\
(1976)\end{array}$ & $\begin{array}{r}1.9 \\
(1984)\end{array}$ & $\begin{array}{r}4.1 \\
(1990)\end{array}$ & $\begin{array}{r}9.7 \\
(1996)\end{array}$ \\
\hline $\begin{array}{l}\text { Cohabitating households (\% all } \\
\text { households) }^{\mathrm{e}}\end{array}$ & & 0.8 & 0.8 & 2.0 & 3.1 & 4.5 \\
\hline $\begin{array}{l}\text { Single occupant households (\% all } \\
\text { households }^{f}\end{array}$ & & 13.1 & 17.1 & 22.7 & 24.6 & 25.5 \\
\hline Median age of first marriage (women) ${ }^{\mathrm{g}}$ & 20.3 & 20.3 & 20.8 & 22.0 & 23.9 & 25.1 \\
\hline
\end{tabular}

Source: ACHS (2000) $)^{\mathrm{a}}$; Pagan and Rector (2000:3) ${ }^{\mathrm{b}}$; AASP (2000a) ${ }^{\mathrm{c}}$; Clem Brooks (2002:198) ${ }^{\mathrm{d}}$; AASP (2000b) ${ }^{\text {e,f }}$; AASP (2000c) ${ }^{\mathrm{g}}$.

(1960) to 3.5 (1970) to 5.0 (1980), while it has dropped off somewhat to 4.7 (1990) and 4.1 (2000). Up until the early 1990s many had concluded that, during the past few 
decades, "family decline is more serious than any decline in the past because what is breaking up is the nuclear family," while "the family as an institution [is] in decline and...this should be a cause for alarm-especially as regards the consequences for children” (Popenoe 1993:527). O’Hara (1995) concluded from this and other evidence that the FCSSA had broken down during the 1970s-1980s and early 1990s.

The drop in the divorce rate (per 1,000 adults) in the 1990s and early 2000s has provided the opportunity for scholars to review the evidence. For instance, Tim Heaton (2002) concludes that the decline in the divorce rate is leading to somewhat greater stability in marriage. Heaton assesses the reasons for the decline as being due to the factors reducing divorce (increasing age of marriage, religious factors, and greater education) recently having more impact than those increasing divorce (black marriages, premarital sex, and cohabitation). This is having the result, it is argued, of increasing stability in marriage.

However, this is unlikely to be happening because, over the past 20 years, other more critical proxies for instability within marriage are not declining. The divorce rate per 1,000 persons overstates "family stability" because an increasing number of people are not marrying; hence the rise in single-person households over the past 40 years. A better proxy for divorce is the divorce rate per 100 marriages, which is shown not to be declining, only leveling off at high rates. Also, there have been increasing rates of cohabitation (not defined as marriage) in the order of 250 percent over the past two decades. If the "de facto marriage" proportion of cohabitation, for instance, is considered a type of marriage, and the dissolution of de facto relationships as a type of divorce, then this would indicate increasing family instability. Hence, on many levels the figures provided by Heaton camouflage what is a more complex and unstable situation.

Closer to the mark is the work of Shawn Haley (2000), who sees a substantial change in the form of households in the United States, including different norms, arrangements, and associations. Table 9.2 summarizes the changes that he isolates. The dominant (old) 1950s/1960s-style family was nuclear, including two opposite-sex adults and at least 2 or 3 children. The emerging (new) 1990s/2000s arrangement is one of multiple, interrelated families, consisting of child-rearing partners from different decades, multiple stepsiblings, parents and grandparents,

Table 9.2 Changes in the US family, 1950s-2000s

\begin{tabular}{|c|c|c|c|c|}
\hline & $\begin{array}{l}\text { Type and } \\
\text { orientation }\end{array}$ & Relationship & Durability & Ethic \\
\hline $\begin{array}{l}\text { 1950s-1970s-style } \\
\text { system }\end{array}$ & $\begin{array}{l}\text { Nuclear, } \\
\text { heterosexual }\end{array}$ & Monogamy & $\begin{array}{l}\text { "Permanent” (20-40 } \\
\text { years) }\end{array}$ & $\begin{array}{l}\text { "Family before } \\
\text { self" }\end{array}$ \\
\hline 2000s-style system & Pluralistic & $\begin{array}{l}\text { Serial } \\
\text { monogamy }\end{array}$ & 10 years, temporary & $\begin{array}{l}\text { "Self before } \\
\text { family" }\end{array}$ \\
\hline
\end{tabular}

and multiple homes for the children. The old system was nominally "permanent," lasting about 20-40 years or more, with "family coming before self." The new system lasts on average a decade, with 2 or 3 such relationships becoming common through a person's life, with "self coming before family." While the old system was mostly heterosexual, the new one is pluralistic: mainly heterosexual, but including some same sex couples, many 
multiple parents, a single custodial parent, or a group of people without children. Strictly speaking, Haley believes the "new” pluralistic family system includes nuclear, extended, matrifocal, and blended varieties. But this is hardly promoting stability and certainty since, as Haley says of this new system:

The bonds between the essential members of the family group...are becoming weaker. People are beginning to see all family arrangements as temporary and the average person will be expected to participate in most or all of them during his or her life.... This combination of family members... and the variability of living arrangements will increase the children's need to be self-reliant.... The family will be a fluid, constantly changing structure with serial monogamy and variable household arrangements as the norm. ${ }^{3}$

(2000:78, emphases added)

Thus, while the emerging normative pattern does have some regularities, overall it is a weaker linkage of human beings, temporary in nature, promoting selfreliance among children, less trust, and a constantly changing structure. ${ }^{4}$ And when divorce emerges there is evidence of a substantial drop in the level of trust that children have for their fathers, who are usually the noncustodial party (King 2002). Currently the American family is experiencing a "nurturance gap" (Stanfield and Stanfield 1997) and an undersupply of “caring labor” (Folbre 1995). As David Ciscel and Julia Heath conclude:

The cultural cage of patriarchy has been replaced by the market's squirrel cage, human relations [being] reduced to transient exchanges. This chimeral freedom puts at risk one of the most important nonmarket institutions that promotes community: lasting social networks and trust as the family withers under the assault of the imperial market.

In this light, stability is not being enhanced, and the contemporary family system is not contributing enough to the emergence of a sustainable SSA. ${ }^{5}$

\section{Trust and association in the 1970s-2000s}

Robert Putman (1995) argues that social capital has deteriorated markedly in the United States during the 1970s, 1980s, and early 1990s. He defines social capital as "features of social organization such as networks, norms, and social trust that facilitate coordination and cooperation for mutual benefit” (1995:66). He puts this trend down to a combination of reduced voter turnout, lower trust in government, less frequent church attendance, a smaller interest in participating in public meetings, declining union membership, reduced membership of parent-teacher associations, fewer volunteers for nonprofit activities, and a disinclination of people to join clubs such as bowling associations. In general, he argues there is less civic engagement, and diminishing space for civil society. This trend has serious implications for democracy, he argues, since the health of the United States as a 
federation has always been dependent upon its civic engagement. Democracy is thus said to be under severe threat.

In more general terms, Putman argues that the bonds within the family have been declining, the relationships between neighbors have fallen considerably, and social relations between individuals and communities have been deteriorating. Trust has especially taken a fall in the past three decades. He posits four main reasons for this decline. First there is the expansion of feminism and the inclusion of women in the workforce, which gives most women fewer hours to engage in civic association. The second is the greater mobility and instability associated with the spread of the automobile, suburbanization, and the greater geographic movement of people. Third is the lower rate of marriage, fewer children, replacement of the corner store with supermarkets, and the development of online shopping. And finally he discusses the importance of television culture, home movies, and electronic technology.

It is critical, he says, to reestablish civil society and social engagement, since the future of democracy, society, and economy depends upon it. Putman's hypothesis has stimulated much controversy as well as attempts at theoretical and empirical scrutiny. In general, social capital has diminished significantly over the past three decades. For instance, the empirical work of Pamela Paxton shows a significant decline in social capital. She distinguishes three types of social capital: trust in individuals, trust in institutions, and levels of civic association. The results are shown in Table 9.3. Paxton studies the degree of perceived "trust" in individuals $(A)$, the degree to which individuals are perceived to be "fair" $(B)$, the degree of trust in institutions $(C)$, and the degree to which people are involved in community associations $(D)$. She also has some composite values, one for total social capital which combines individuals, institutions, and associations $(E)$, and the second that examines the degree to which people are both trusting and associating $(F)$.

A number of conclusions are made. First, individual social capital has declined markedly, especially for the percentage of people who are both trusting and associating, which declined over the two decades by 41.1 percent. The scale of individuals who can be trusted declined by 20.21 percent, while the scale of individuals who are perceived to be fair declined even more by 24.65 percent. The scale of total social capital, including individuals, institutions, and associations declined over the period by 18.98 percent. In general, the results demonstrate a quite significant decline in social capital, especially for total individual social capital but also for social capital as a whole.

This is the main conclusion, that trust in both individuals and institutions (for the highest categories) have declined significantly, especially for individuals.

Table 9.3 Trust in individuals and institutions,
association and total social capital, 1975-1994

19751980198519901994 Percent change 19751994
A Individuals can be "trusted" (scaling
$\begin{array}{lllll}0.495 & 0.470 & 0.445 & 0.420 & 0.395\end{array}$
$-20.21$ indicator probabilities)
B Individuals are "fair" (scaling indicator
$\begin{array}{lllll}0.495 & 0.460 & 0.430 & 0.400 & 0.373\end{array}$
$-24.65$ 


\begin{tabular}{|c|c|c|c|c|c|c|c|}
\hline & probabilities) & & & & & & \\
\hline $\mathrm{C}$ & $\begin{array}{l}\text { Trust in institutions (highest category; } \\
\text { average) (scaling predicted probabilities) }\end{array}$ & 0.188 & 0.183 & 0.178 & 0.172 & 0.162 & -13.83 \\
\hline $\mathrm{D}$ & Civic association (predicted values) & 5.715 & 5.720 & 5.725 & 5.730 & 5.735 & +3.50 \\
\hline $\mathrm{E}$ & $\begin{array}{l}\text { Total social capital: individuals, } \\
\text { institutions, and associations (mean of } \\
\text { scaling indicator) }\end{array}$ & 8.43 & 8.33 & 7.9 & 7.43 & 6.83 & -18.98 \\
\hline $\mathrm{F}$ & $\begin{array}{l}\text { Total individual social capital: percent } \\
\text { both trusting and associating }\end{array}$ & 14.6 & 15.0 & 13.6 & 11.35 & 8.6 & -41.10 \\
\hline
\end{tabular}

Source: Adapted from various parts of Paxton (1999:115, 116, 120, 121).

Individuals demonstrate a considerable lack of trust, but also a decline in the belief that people are "fair" and also (not shown) that they are "helpful," the degree of fairness and helpfulness actually declining more than trust. Overall, there is evidence that the social capital aspect of the community has declined considerably as trust (as well as "fairness" and "helpfulness") has deteriorated over the two decade period. ${ }^{6}$

Levels of association seem to be relatively stable through time. However, disaggregating associations reveal some interesting results (Paxton 2002). First, working people and the poor have significantly reduced their participation in associations while middle and upper middle class people have kept their associational linkages relatively stable. The concerns of the lower echelons of society are losing organized recognition while middle class concerns are being sustained through a whole series of linkages to enhance professional standing, sociopolitical concerns, think tanks, and lifestyle interests (Skocpol 2002:17-18).

Second, there is a decline in the level of charitable and "helping" association as the level of trust declines and inequality increases. Associations dealing with "making money," job prospects, and advocacy have expanded. The rise in individualism thus led to a drop in concern for other human beings, progressive increases in inequality, and a decline in group affiliation involving all classes. The result is greater familiarity with and acceptance of social cleavage (Uslaner 2002:22).

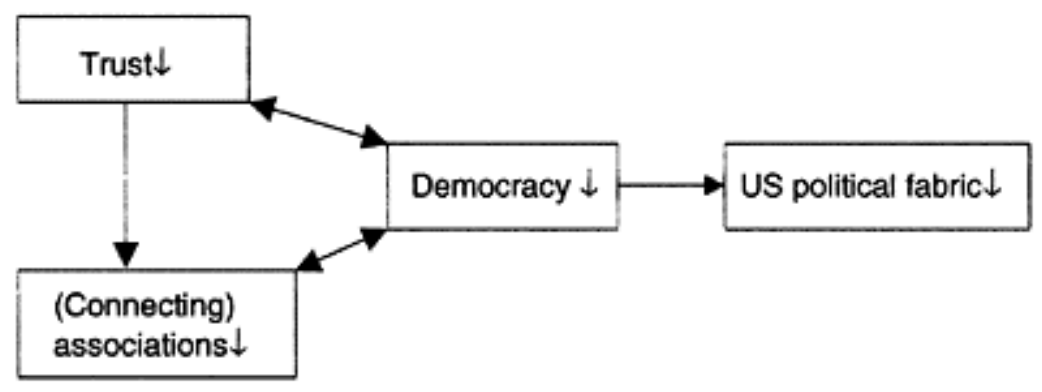

Figure 9.4 Relationship between trust, associations, and democracy. 
Third, there has indeed been a drop in civic engagement involving political activity. Voter turnout on election day has decreased, membership and participation in political parties has diminished, and interest in debating politics in civil society has declined considerably. Much is being written and debated on this subject, since the very health of the "American way of life"-indeed, of democracy itself- has historically been assumed to depend on civic participation in politics, debating the issues, and engaging in social actions deserving of citizens.

In her empirical analysis, Paxton (2002) shows that there is a reciprocal relationship between social capital and democracy, and that "connected associations" have a strong positive influence on democracy while "isolated associations" have a negative influence. The main results are that there is a strong reciprocal relationship between connected associations and democracy and also between trust and democracy, while the number of connected associations has declined relative to isolated associations. Associations enhance democracy only when the level of trust is relatively high: "associations in a climate of distrust are potentially harmful to democracy," as is increasingly the case (Paxton 1999:272). These relationships are shown in Figure 9.4.

This illustrates, in the contemporary environment, that the declining level of trust is adversely affecting democracy and the quality of associations, which in turn is negatively impacting on democracy. The critical factor is trust. The significant drop in trust over recent decades, and the relatively low level of trust, implies that democracy is being eroded in the United States. This is a major problem of capitalism in the United States, a country that has always prided itself on its democratic way of life and the trustworthiness of its citizens. It represents one dimension of the deteriorating social and political fabric of US capitalism in its neoliberal phase of evolution.?

\section{Cultural relations and inequality}

The last dimension of the FCSSA concerns structural factors that inhibit community solidarity, connectivity, and equality. As Geoffrey Hodgson (2004) recognizes, there are two very broad factors promoting an individual's position in society, first, those peculiar to the individual, and second, those under the influence of society, family, and other groups. Here we examine the latter type of influence. The central concern is the degree to which the position of the individual is inhibited by factors largely beyond their control such as the family they are brought up in, their age, ethnicity, gender, and place of birth (Egerton 1997). A FCSSA requires that individual initiative or social forces create (more) opportunities for individuals to be rewarded according to their own effort and activity rather than according to their family, group, social, or geographical position. Specifically, we are looking at the question as to whether such factors have improved since the 1970s, which may enhance the creation of a new FCSSA.

Table 9.4, presents summary indicators of the importance of "structural factors" in the US economy over recent years, particularly since the 1980s. The general story that these figures tell is straightforward enough. Inequality in the United States has progressively increased through the 1980s and 1990s. Class distinctions have expanded as the ability of middle and upper class parents to pass socioeconomic advantages on to their children has increased while that of working and lower classes has diminished. The measure of intergenerational elasticity of family income on son's earnings increased from 0.217 
(1980) to 0.414 (1993). However, "nearly all of the increase in the intergenerational elasticity... of income operates outside of the [human capital] channels that have been traditionally studied by economists” (Levine and Mazumber 2002:25). Bowles and Gintis (2002:17), for instance, demonstrate that the major factors

\section{Table 9.4 Indicators of significance of structural factors in US economy}

\begin{tabular}{|c|c|c|c|c|}
\hline & $\begin{array}{l}\text { Early-mid- } \\
1970 \text { s }\end{array}$ & Early 1980s & Early 1990s & $\begin{array}{l}\text { Later in } \\
1990 s\end{array}$ \\
\hline Inequality (Gini coefficent) ${ }^{\mathrm{a}}$ & $0.305(1970)$ & $0.315(1980)$ & $0.361(1990)$ & 0.401 (1999) \\
\hline $\begin{array}{l}\text { Intergenerational elasticity } \\
\text { ("class") }^{\mathrm{b}}\end{array}$ & & $0.217(1980)$ & 0.414 (1993) & \\
\hline Child health index ${ }^{\mathrm{c}}$ & 100 (1975) & 103.5 (1983) & $91.8(1991)$ & $81.4(1998)$ \\
\hline Child social relations index ${ }^{\mathrm{d}}$ & 100 (1975) & 83.5 (1983) & 73.7 (1991) & $67.2(1998)$ \\
\hline "Black" discrimination coefficient ${ }^{\mathrm{e}}$ & $-0.126(1976)$ & $-0.115(1980)$ & $-0.119(1990)$ & $-0.140(1995)$ \\
\hline $\begin{array}{l}\text { "Black" children born in "extreme } \\
\text { poverty" areas }{ }^{f}\end{array}$ & $\begin{array}{l}10.8 \%(1971- \\
1972)\end{array}$ & $\begin{array}{l}24.3 \%(1980- \\
1981)\end{array}$ & $\begin{array}{l}28.2 \%(1990- \\
1991)\end{array}$ & $\begin{array}{l}40.2 \%(1992- \\
1993)\end{array}$ \\
\hline $\begin{array}{l}\text { Regional income divergence } \\
\text { coefficient }^{\mathrm{g}}\end{array}$ & $0.053(1970)$ & $0.034(1980)$ & $0.0473(1990)$ & 0.0425 (1994) \\
\hline Gender equality index ${ }^{\mathrm{h}}$ & & $\begin{array}{l}55(1997- \\
1983)\end{array}$ & & $\begin{array}{l}62(1989- \\
1996)\end{array}$ \\
\hline
\end{tabular}

Source: O’Hara (2004: ch 2) ${ }^{\mathrm{a}}$; Levine and Mazumber (2002:29) ${ }^{\mathrm{b}}$; Di Noia (2002:58) ${ }^{\mathrm{c}, \mathrm{d}}$; Darity et al. (2001) $)^{\mathrm{e}}$; Timberlake (2002:39) ${ }^{\mathrm{f}}$; Key and Montouri (1999:150) ${ }^{\mathrm{g}}$; Land et al. (2001:279) ${ }^{\mathrm{h}}$.

promoting intergenerational transfers over time are, in order of importance, (a) environmental factors within families and groups (correlation of 0.2), (b) wealth of families and groups (0.12), and genetics (0.09), giving an overall correlation of 0.41 .

The environmental influences have been studied by a number of authors, such as Annette Lareau (2002:772) who argues that "class position influences critical aspects of family life: time use, language use, and kin ties.... [P]arents do transmit advantages to their children in patterns that are sufficiently consistent and identifiable to be described as a 'cultural logic' of childrearing." Middle class parents have the cultural logic of "concerted cultivation," where they actively foster and assess the talents, opinions, and skills of their children, organize multiple leisure activities, give reasoned directives while allowing contestation and negotiation in decision-making, have weak extended family ties, but more links to the wider community, and encourage a sense of entitlement among children. Working class and poor parents, on the other hand, tend to concentrate on "natural growth" with less guidance, providing directives to children without contestation; and contributing a source of constraint on child development.

A similar empirical assessment is provided by Carl Bankston and Min Zhou (2002), who conclude that the role of intergenerational networks are critical to class and ethnic advantages. They demonstrate that the network ties among parents, children, and friends 
are significantly weaker among lower classes, Blacks, Asians, and Latinos than middle and upper classes and Whites. Family income and education is positively associated with network ties, especially through the role of the high status, working mother who generally has an active role to play in these networks. Single parents and nonworking mothers have significantly less impact than couples and working mothers. Thus:

Residential stability, knowing the neighbors, parental membership in organizations, and children's involvement in...institutions are all positively associated with connections among parents and children.... Family income is positively associated with educational aspirations, but negatively related to an orientation to industriousness.

(Bankston and Zhou 2002:301, 304)

Through the 1980s and 1990s class distinctions, in particular, have become more noticeable as inequality has increased and trust declined. Child health has deteriorated as their food quality has declined and obesity increased. The ability of children to engage in durable relationships has deteriorated as their geographic movement has been enhanced and stability of home base decreased. Black discrimination in the labor market has not decreased during the 1980s and 1990s, if anything increased somewhat, as ethnic stereotyping continues, relative poverty rises, and the impact of the distant past continues in the present through hysteresis (Darity et al. 2001). The "discrimination coefficient" declined a lot between 1964 and 1978, but since then "progress [has] ceased," and even seems to be getting worse into the 1990s (since the deep recession of the early 1990s, and also likely since the recession and collapse of the early 2000s). Children born to black families are much more likely to come from extremely poor neighborhoods. Locational inequities have become greater during the 1980s and 1990s (although reduced a little in the early 1990s), as the dual process of uneven development of cities and states reaps rewards for the northeast and west while the south continues to be disadvantaged in relative terms. And while women have improved their position in the labor market and at home, they are still not even at two-thirds the income level of men, according to the gender equality index.

The institutional environment is thus a critical factor influencing the social and political economy. Intergenerational relative transfers have expanded for the upper classes and diminished for the lower classes over the past 20 years in the United States. This is not due to an increase in industriousness on the part of those who have benefited and a decline in the work ethic of the worse off, but rather it is mainly due to a differential level of acquisition of networks of association and cultural traits. There is more inequality between those who have familial and social advantages and those who lack such intergenerational transfers. Many children are thus disadvantaged by factors that are outside their immediate control, which continue to influence their life chances and income for many decades or longer. Structured inequality is thus more entrenched as we move into the new millennium. 


\section{Major contradictions and economic performance}

Linking together the three main factors of familial, social, and cultural relations within the circuit reveals a critical contradiction of the neoliberal phase of capitalism during the 1980s, 1990s, and 2000s. It has to do with the negative relationship between trust and inequality/instability, and the impact of declining trust and rising inequality/instability on socioeconomic reproduction within the circuit. The contradictory stability-trust-inequality motion is illustrated in Figure 9.5. ${ }^{8}$

The last three decades of the twentieth century has seen an expansion of market-based economics and business. People have on average taken to working longer hours, having stronger links to their work environment, and participating less in family, social, and political activities. Individualism has risen, leading to a reciprocal decline in trust and an increase in inequality and instability. This decline in trust and increase in inequality and instability is a volatile mix since it leads to many socioeconomic problems and increases the level of uncertainty in the social environment. This leads to amplified costs, difficulties in the circuit, and greater uncertainty in the macro and global economy. It thus represents a core contradiction of contemporary capitalism, in the sense of representing an endogenous source of socioeconomic problems.

This links to the breakdown in society. The cultural fabric of the nation, in the age of neoliberalism, is fraught with inequities, greater market dominance, the hegemony of shareholder valuation, and corporate dominance of the way of life (O'Hara 2004a). The rich have been getting richer, the poor getting poorer, people

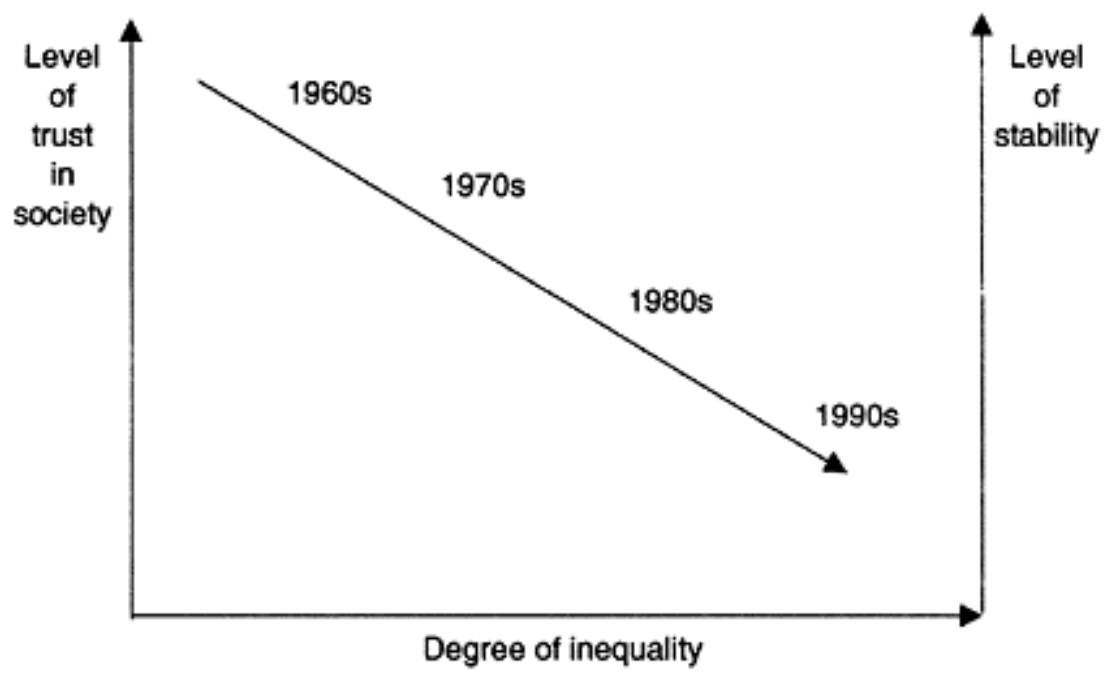

Figure 9.5 Contradictory stabilitytrust-inequality motion. 
paying more attention to work and occupation, and their own "individuality" is privileged over social considerations. The culture is one that is increasingly oriented around money, individual reward, and social esteem based on market criteria. Economy is dominant over society, as nonmarket relations decline and the space for familial, political, and civil society deteriorates. Social uncertainty is expanding and the disembedded economy paves the way for major periodic crises of economy and finance (Polanyi 1944).

We come now to the specific transmission mechanisms. First, consider the family. Familial instability has increased with the relative breakdown of the traditional nuclear family, the emergence of a new pluralistic family system, an increasing number of people deciding not to marry, and an expansion of cohabitation. Increasing family instability leads to declining social safety nets and greater uncertainty of life, which impacts negatively on the ability of people to plan for the future. The relationship between familial stability and economic performance is multifarious. The decline in family stability has been documented by some studies (e.g. Devitte 2000; Fagan and Rector 2000) although it is an under-scrutinized area empirically. However, it seems to be an uncontroversial conclusion that the declining level of family stability in the United States has affected various aspects of economic performance. This occurs through a variety of transmission mechanisms, some of which are summarized in Table 9.5.

Being born outside marriage and especially to a single parent results in lower income, resources, and emotional support. Declining trust in families promotes greater costs of interaction and a decline in the quality of social knowledge. Eating out more at fast food joints, and greater use of television, VCRs and computers results in weight gain and lower health. And changing linkages to parents and different homes result in the need to be more independent and less

\section{Table 9.5 Impact of declining familial stability on economic performance}

\begin{tabular}{|c|c|c|c|c|}
\hline Variable & Study & Influence & $\begin{array}{l}\text { Transmission } \\
\text { mechanism }\end{array}$ & Impact \\
\hline $\begin{array}{l}\text { Birth outside } \\
\text { marriage and single } \\
\text { parents }\end{array}$ & $\begin{array}{l}\text { Devitt } \\
(2000)\end{array}$ & Family stability & $\begin{array}{l}\text { Lower income, } \\
\text { resources and emotional } \\
\text { support }\end{array}$ & Multiple \\
\hline Declining trust & $\begin{array}{l}\text { Zak and } \\
\text { Knack } \\
(2001)\end{array}$ & $\begin{array}{l}\text { Reduces communication } \\
\text { and information certainty }\end{array}$ & $\begin{array}{l}\text { Higher costs and less } \\
\text { knowledge }\end{array}$ & Multiple \\
\hline Health & $\begin{array}{l}\text { Land et al. } \\
\text { (2001) }\end{array}$ & Weight and food quality & Human capital & Multiple \\
\hline Relationships & $\begin{array}{l}\text { Land et al. } \\
\text { (2001) }\end{array}$ & $\begin{array}{l}\text { Changing residents and } \\
\text { homes }\end{array}$ & $\begin{array}{l}\text { Less emotional bonding } \\
\text { and trust }\end{array}$ & Multiple \\
\hline
\end{tabular}

emotionally attached. Overall, less emotional support, increasing costs of interaction, declining (child) health, less trust, and greater uncertainty negatively impact on the personality and human capital of children as well as the reproducibility of the socioeconomic environment. 
Second, social trust has diminished, thus increasing the level of uncertainty in socioeconomic and political life. A decline in trust leads to an expansion of security costs and reduces the turnover of capital. In essence, trust is being undermined in the family, in the wider society, among social groups, and in business dealings. The essence of familial, social, and cultural relations is trust; the ability to believe what others have told you, that they will keep their word, that they will support you in times of need, and that they will remain in close contact with you. Trust is undermined as families start to break up, as class distinctions get greater, as discrimination festers, and as the social fabric is fraught with effective contradictions. The critical thing to note is that this impacts on the quality of life, standard of living, happiness, and lifestyle of people. Instability rises in the family, democracy is under threat, and social distinctions become greater. The whole system as well as its parts undergo conflicting processes and strains begin to emerge in the social, political, and economic edifice.

Part of the edifice affected by trust is the economy. Social trust is critical to economic performance. It reduces transaction costs, increases the propensity to save and invest, and expands the income of its citizens. Theoretical and empirical studies (such as Yamagishi and Yamagishi 1994; Knack and Keefer 1997) have repeatedly shown a positive correlation and causal link between social trust and economic performance. At the broader level, greater inequality and discrimination reduce trust (Kawachi et al. 1997), while common language and custom enhance trust (Helliwell 2000). At the narrower level, in a cross-country survey for 41 nations (including the United States), Zak and Knack (2001) provide evidence that higher levels of trust expand investment and income through reducing moral

\section{Table 9.6 Influence of trust on investment and GDP, 1970-1992}

\begin{tabular}{llll}
\hline Dependent variable $\Rightarrow$ & $\begin{array}{l}\text { Investment } \\
\text { share GDP }\end{array}$ & $\begin{array}{l}\text { GDP annual } \\
\text { growth }\end{array}$ & Trust \\
$\begin{array}{l}\text { Causal variable } \Downarrow \\
\begin{array}{c}\text { Trust } \uparrow 7 \\
\text { percentage points }\end{array}\end{array}$ & $\begin{array}{c}\uparrow 1 \text { percentage } \\
\text { point }\end{array}$ & $\begin{array}{c}\uparrow 1 \text { percentage } \\
\text { point }\end{array}$ & \\
$\begin{array}{c}\text { Trust } \uparrow 15 \\
\text { percentage points } \\
\text { Discrimation } \uparrow 1 \text { points } \\
\text { (4-point scale) }\end{array}$ & & $\begin{array}{c}\downarrow 5 \text { percentage } \\
\text { points }\end{array}$ \\
\hline
\end{tabular}

Source: Adapted from Zak and Knack (2001: 307, 312-314).

hazard between principals and agents such as "investors" and brokers, which can be generalized to workers and capitalists, creditors and debtors, clients and consultants, insurers and insured, as well as retailers and customers. The technical results obtained are summarized in Table 9.6.

There was some degree of two-way causation between variables, but while controlling for this it was found that an increase in trust in the order of 7 percentage points resulted in 
an annual expansion in investment of 1 percentage point, an increase in trust of 15 percentage points resulted in a annual expansion in growth of 1 percentage point, and an increase in discrimination in the order of 1 point (on a 4-point scale) resulted in a drop in trust of 5 percentage points. (Scandinavian nations had the highest level of trust.) Their conclusions were that:

The amount invested decreases as social heterogeneity increases, and when formal and informal institutions are weaker, adversely impacting [on] income growth. [P]roxies for formal institutions, social distance and discrimination...suggest that much of their influence on growth occurs through their impact on trust Trust, and the social and institutional factors that affect it, significantly influence growth rates. Thus, this research provides a new insight into the way that social and institutional factors impact [on] economic performance.

(Zak and Knack 2001:316-317)

The fabric of institutions, inequality, and custom influences and is affected by trust, which in turn affects and is also influenced by investment and growth. At a general societal level, trust and GDP growth are positively related. At the disaggregated level, of course, trust may be encapsulated and exploited by sectional interests against the common good, as many authors have recognized. ${ }^{9}$ As the level of social trust has declined in the United States considerably over the past three decades, this has had a critical impact on the economic performance of the nation.

Third, an increase in inequality and diminishing interaction between the social classes enhances the potential for social and financial instability. Established theory, such as the Kuznets' inverted U curve, suggests that at low levels of development inequality increases as cities grow and rural areas decline, while at high levels of development inequality declines as convergence and trickle down becomes significant. But the recent increases in inequality in the United States and advanced nations (at least) - during the 1970s-1990s - has seen a rethink in the literature. Many theoretical and empirical papers are arguing that inequality retards growth and investment. A whole series of papers are utilizing recent theoretical advances in their empirical work to postulate that inequality retards investment and growth due to factors that support the need for egalitarian policies and perspectives. $^{10}$

For instance, Philippe Aghion et al. (1999:1654-1657) argue that the recent increase in inequality in the advanced nations is due to recent trends in trade liberalization, technical change, and organizational forms. Trade liberalization has enabled material inputs to decline in price relative to unskilled labor, leading to a substitution toward material inputs and an expansion of outsourcing of unskilled labor along with declining rewards to such labor. The expansion of new technology and education led to a declining relative wage for old skills, which in the short-to-medium run most workers have. As organizations change external labor, flexibility leads to greater competition and hence wage inequality. In this environment, an expansion of inequality can lead to lower economic growth when there are heterogeneous agents, capital market imperfections, and wealth constraints. Heterogeneous agents mean that there are different classes of managers, workers, and supervisors. Imperfections in the capital market mean that there 
may be a lack of credit for many good projects while a number of bad ones proliferate. And wealth constraints mean that many people with good projects will be unable to finance their projects while many with worse ones will go ahead, due to inequality.

Under these conditions, the increase in inequality over the past 30 years has been negatively impacting on growth within the circuit. Three mechanisms whereby the negative impact of inequality on growth has occurred is shown in Figure 9.6. First, inequality reduces investment opportunities for those with good projects but little wealth or credit; working and lower classes. Many people will not invest due to lack of funds, rather than a lack of viable projects (Gottschalk 1997). Second, inequality worsens borrowers' incentives because they will often borrow due to a lack of cash flow, due to their class position. And third, this leads to greater volatility because those who save are often different from those who invest, and an increase in borrowing due to inequality leads to greater credit crises. Inequality reduces investment, expands credit, and enhances volatility. In order to counter these negative impacts on growth, Aghion et al. (1999:1656) argues that governments can help rectify the problems to some extent by "investing in infrastructure or in human capital, or reducing bureaucratic obstacles... [which] would reduce entry barriers and promote growth.” Proactive policies to expand physical, human, and social capital could help to alleviate problems resulting from differential access to credit, wealth, and capital. Indeed, current research indicates that productive government investment on infrastructure,

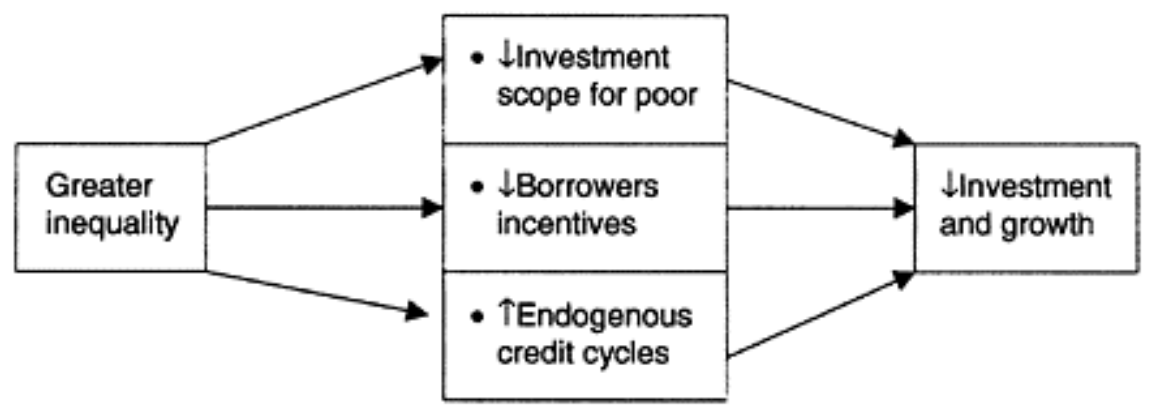

Figure 9.6 Three mechanisms where inequality lowers growth.

education, health, and communications tend to crowd in private investment while the use of transfer payments crowds out. Scope exists, therefore, for a proactive system of public capital formation to reduce inequality and expand investment and growth (and thereby reduce the need for certain transfer payments; see Chapters 3 and 10 for more detail). ${ }^{11}$

\section{Conclusion}

The purpose of this chapter has been to study the question of whether a new familycommunity social structure of accumulation is in motion at present in the United States. Were such a system being activated it would make a contribution to long-term growth 
and development within the systemic circuit of social capital. Three areas were scrutinized: familial, social, and cultural relations within the circuit. In none of the areas were significant inroads being made; in fact, mostly things have gotten worse over the past 20 years.

The old nuclear family is breaking down and a transition period is in motion toward a new pluralistic structure. Evidence demonstrates that neither the transition nor the new structure is promoting stability, enhancing child human capital, or social relationships. Familial trust is in decline, and the pluralistic trend is not providing sufficient communication and bonding to enhance certainty and stability.

Social capital is also in decline as social trust has progressively diminished over the past 30 years. People are less able to depend on others to provide support, empathy, resources, and care when the need arises. The economy is less embedded in society as reciprocity, redistribution, and instrumental customs decline in favor of individual motives and gain. Democracy and community are under threat since people spend less time involved in connective associations in civil society relative to associations linked to money, career, and advocacy.

There has also been a decline in cultural embeddedness as inequality has increased. Recent trends have seen an expansion in the ability of middle and upper classes to gain benefits for their children that the lower classes are unable to provide. Black children are also much more likely to be born into poor areas. Linkages between classes in particular have diminished, leading to a decline in inter-class trust.

The threefold diminution in family stability, social trust, and equality is a volatile contradiction that has led to a deteriorating social fabric. Economic performance has also suffered as family instability reduces the quality of social bonding, reduced trust increases the cost of transactions while it reduces the level of effective communication, and increased inequality reduces the potential for those with latent talent to expand productivity, investment, and growth. At every level, therefore, we find no support for a new family-community social structure of accumulation, and hence on this score long wave downswing is likely to continue into the foreseeable future.

\section{Notes}

1 An earlier version of this chapter was presented at the combined ASE-AFEE sessions of the ASSA, January 2-5, 2003, Washington, DC. The author wishes to thank Jonathan Goldstein, Terry McDonough, Ron Stanfield, and Patrick Welch for comments and encouragement on the earlier version. An earlier version was published in the Forum for Social Economics, Volume 34, Number 2, Fall (O’Hara 2004b).

2 The project of modifying and extending the CSC is a critical one in contemporary political economy. This is because the CSC is a powerful tool of analysis, yet the contemporary economy is a complex one that requires expanding the linkages in the analysis. See previous chapters for further applications of the CSC to the global and national economies.

3 The Journal of Marriage and Family in 2004 had a special issue dealing with a symposium on "marriage and the family" (Walker 2004). In it, Andrew Cherlin analyzes the deinstitutionalization of American marriage, including possible alternative futures for the family. The two most likely scenarios explored include (a) where "marriage remains deinstitutionalized but is common and distinctive" such that "The commitment of partners to be trustworthy has been undermined by frequent divorce"; and (b) the "fading away of marriage" such that there is a "predominance of fragile relationships that are continually at 
risk of breaking up because they are held together entirely by the voluntary commitment of each partner” (Cherlin 2004:857-858).

4 A critical factor promoting instability in the institution of the modern family is the gender dialectic. This links to the contradiction that men are generally not willing enough to contribute to household labor, while women have not been sufficiently proactive in including men in decisions about having children. This leads to much instability in marriage, and is an ongoing research program of mine. I have only published on one aspect of this contradiction: the inability of men to undertake sufficient household labor (see O’Hara 1995).

5 It may be argued by some that the type of family structure being developed at present is flexible, suitable to individual taste, and in line with postmodern or similar changes in economy and society. However, the balance of the evidence does not support this conclusion. The current family structure and pattern of evolution is contradictory because it satisfies individual but not systemic needs, it promotes fluidity without sufficient certainty, it substitutes too many market like dynamics instead of public goods that promote stability, conflict resolution, and performance.

6 One dimension of social capital, the "fairness" of individuals has declined from a predicted probability of 0.495 (1975) to 0.375 (1994), while "helpfulness" has declined from 0.495 (1975) to 0.390 (1994). Trust in institutions examined education, religion, the executive, and the legislature (Paxton 1999:115).

7 A number of studies have examined the link between democracy and economic performance. Rodrik, for instance, empirically examines the role of political rights, civil liberties, and participatory democracy and concluded that democracies perform better on a number of dimensions: they produce less randomness and volatility, they are better at managing shocks, and they yield distributional outcomes that are more desirable. One interpretation of the results, and the one that I have emphasized throughout, is that democracy helps build better institutions. (2000:28).

8 Uslaner (2002:49) concludes in his comparative analysis of the link between trust, inequality and association that "if there is a connection between inequality and engage ment, it is indirect, through inequality's depressing effect on trust.”

9 Evidence from a variety of sources demonstrate the need for trust at the macro and micro levels. It is critical to have a high level of general societal trust, but also important to have trust in the household and between households and society as a whole. Too much trust within small groups, rather than between groups and at the societal level can expand the level of organized crime and vested interests that exploit the social wealth. See Sobel (2002), Helliwell and Putman (2000), and Woolcock (1998) for details of these debates.

10 Of course, a number of scholars still go back to conservative economics and argue that equality retards growth because it propels redistributive policies that provide a disincentive for investment (see, for instance, Knowles 2001).

11 This is the evidence provided by a whole series of comparative studies into the role of productive government spending (see O'Hara 2004c).

\section{References}

AASP (American Association for Single People). (2000a) Divorce Trends: 1970-2000. http://www.singlesrights.com/Census\%202000/divorce-trends.htm (accessed December 15, 2002).

AASP. (2000b) Households by Size: 1960-2000. http://www.singlesrights.com/\%20Census\%\%20202000/households-type-trends-singleoccupant-htm (accessed December 15, 2002). 
AASP. (2000c) Median Age of First Marriage: 1950-2000.

http://www.singlesrights.com/\%20Census\%202000/age-first-marriage-trendss.htm (accessed December 15, 2002).

ACHS (Alabama Center for Health Statistics). (2000) Divorces and Divorce Rates: Alabama \& US, 1945-2000. http://ph.state.al.us/chs/HealthStatistics/Tables/2000/\%20aveTAB71.htm (accessed December 15, 2002).

Aghion, P.E.Caroli and C.Carcia-Penalosa. (1999) "Inequality and Economic Growth: The Perspective of the New Growth Theory,” Journal of Economic Perspectives, Volume 37, Number 4, pp. 1615-1660.

Bankston III, C.L. and M.Zhou. (2002) "Social Capital as Process: The Meanings and Problems of a Theoretical Metaphor," Sociological Inquiry, Volume 72, Number 2, pp. 285-317.

Bowles, Samuel and Herbert Gintis. (2002) “The Inheritance of Inequality,” Journal of Economic Perspectives, Volume 16, Number 3, pp. 3-30.

Brooks, C. (2002) "Religious Influence and the Politics of Family Decline: Trends, Sources, and U.S. Political Behavior,” American Sociological Review, Volume 67, Number 2, pp. 191-211.

Castells, M. (1980) The Economic Crisis and American Society, Princeton, NJ: Princeton University Press.

Cherlin, Andrew J. (2004) “The Deinstitutionalization of American Marriage,” Journal of Marriage and Family, Volume 66, Number 4, pp. 848-861.

Ciscel, David H. and Julia A.Heath. (2001) “To Market, to Market: Imperial Capitalism’s Destruction of Social Capital and the Family," Review of Radical Political Economics, Volume 33, Number 4, pp. 401-414.

Darity, William Jr, J.Dietrich and D.K.Guilkey. (2001) "Persistent Advantage or Disadvantage: Evidence in Support of the Intergenerational Drag Hypothesis," American Journal of Economics and Sociology, Volume 60, Number 2, pp. 435-470.

Devitte, J. (2000) Single Mothers and their Children: A New American Dilemma? Washington, DC: The Urban Institute.

Di Noia, J. (2000) “Indicators of Gender Equality for American States and Regions: An Update," Social Indicators of Research, Volume 59, pp. 35-77.

Egerton, M. (1997) “Occupational Inheritance: The Role of Cultural Capital and Gender,” Work, Employment and Society, Volume 11, Number 2, pp. 263-282.

Pagan, P.F. and R.Rector. (2000) The Effects of Divorce on America, Washington, DC: Heritage Foundation.

Folbre, Nancy. (1995) “Holding Hands at Midnight: The Paradox of Caring Labor," Feminist Economics, Volume 1, Number 1, pp. 73-92.

Gottschalk, P. (1997) “Inequality, Income Growth and Mobility: The Basic Facts,” Journal of Economic Perspectives, Volume 11, Number 2, pp. 21-40.

Haley, Shawn (2000) “The Future of the Family in North America,” Futures, Volume 32, Number 8, pp. 777-781.

Heaton, Tim B. (2002) "Factors Contributing to Increasing Marital Stability in the United States," Journal of Family Issues, Volume 23, Number 3, pp. 392-409.

Helliwell, John. (2000) "Balanced Growth: The Scope for National Policies in a Global Economy," in M.Richardson (ed.), Globalisation and International Trade Liberalisation, Cheltenham, UK and Northampton, MA: Edward Elgar.

Helliwell, John and Robert D.Putman. (2000) “Economic Growth and Social Capital in Italy,” in P.Dasgupta and I.Serageldin (eds), Social Capital: A Multifaceted Perspective, Washington, DC: World Bank. Reprinted from the Eastern Economic Journal (1995), Volume 21, Number 3, pp. 253-268.

Hodgson, G.M. (2004) Reconstructing Institutional Economics: Evolution, Agency and Structure in American Institutionalism, London and New York: Routledge. 
Kawachi, I, B.P.Kennedy, K.Lochner, and D.Prothrow-Smith. (1997) “Social Capital, Income Inequality, and Mortality,” American Journal of the Public Health, Volume 87, Number 9, pp. 1491-1498.

King, V. (2002) “Parental Divorce and Interpersonal Trust in Adult Offspring,” Journal of Marriage and Family, Volume 64, Number 3, pp. 642-656.

Knack, Stephen, and P.Keefer. (1997) "Does Social Capital have an Economic Payoff? A CrossCountry Investigation,” Quarterly Journal of Economics, Volume 112, Number 4, pp. 12521288.

Knowles, S. (2001) Inequality and Economic Growth: The Empirical Relationship Reconsidered in the Light of Comparable Data, University of Otago, New Zealand: Department of Economics, Working Paper.

Land, K.C, V.Lamb, and S.K.Mustillo. (2001) "Child and Youth Well-Being in the United States, 1975-1998: Some Findings from a New Index,” Social Indicators Research, Volume 56, Number 3, pp. 241-320.

Lareau, A. (2002) "Invisible Inequality: Social Class and Childrearing in Black Families and White Families,” American Sociological Review, Volume 67, Number 5, pp. 747-776.

Levine, D.I. and B.Mazumber. (2002) Choosing the Right Parents: Changes in the Intergenerational Transmission of Inequality—Between 1980s and the Early 1990s, Chicago, IL: Federal Reserve Bank of Chicago, Working Paper 2002-08.

Marx, Karl. (1885) Capital: A Critique of Political Economy: Volume 2-the Process of Circulation of Capital, Harmondsworth: Penguin, 1981.

Moseley, Fred. (1997) “The Rate of Profit and the Future of Capitalism,” Review of Radical Political Economics, Volume 29, Number 4, pp. 410-438.

O’Hara, Phillip Anthony. (1995) "Household Labor, the Family, and Macroeconomic Instability in the United States: 1940s-1990s,” Review of Social Economy, Volume 53, Number 1, pp. 89120.

O’Hara, Phillip Anthony. (2000) Marx, Veblen and Contemporary Institutional Political Economy: Principles and Unstable Dynamics of Capitalism, Cheltenham, UK and Northampton, MA: Edward Elgar.

O’Hara, Phillip Anthony. (2001) “Circuit of Social Capital,” in P.A.O’Hara (ed.), Encyclopedia of Political Economy, London and New York: Routledge, pp. 84-87.

O’Hara, Phillip Anthony. (2004a) "Wealth and Welfare of Nations, Continents and Corporations," in P.A.O’Hara (ed.), Global Political Economy and the Wealth of Nations: Performance, Institutions, Problems and Policies, London and New York: Routledge, pp. 39-62.

O’Hara, Phillip Anthony. (2004b) "A New Family-Community Social Structure of Accumulation for Long Wave Upswing in the United States?,” Forum for Social Economics, Volume 34, Number 2, Spring, pp. 51-80.

O’Hara, Phillip Anthony. (2004c) "Viability of National Government Policies in a Global Political Economy,” in P.A.O’Hara (ed), Global Political Economy and the Wealth of Nations:

Performance, Institutions, Problems and Policies, London and New York: Routledge, pp. 327346.

Paxton, Pamela. (1999) "Is Social Capital Declining in the United States? A Multiple Indicator Assessment,” American Journal of Sociology, Volume 105, Number 1, pp. 88-127.

Paxton, Pamela. (2002) "Social Capital and Democracy: An Interdependent Relationship," American Sociological Review, Volume 67, Number 1, pp. 254-277.

Polanyi, Karl. (1944) The Great Transformation, Boston, MA: Beacon Press, 1982.

Popenoe, D. (1993) “American Family Decline, 1960-1990: A Review and Appraisal,” Journal of Marriage and the Family, Volume 55, Number 3, pp. 527-541.

Putman, Robert. (1995) “Bowling Alone: America’s Declining Social Capital,” Journal of Democracy, Volume 6, Number 1, pp. 65-78.

Resnick, Stephen A. and Richard D.Wolff. (2002) Class Theory and History: Capitalism and Communism in the U.S.S.R, London and New York: Routledge. 
Rey, S.J. and B.D.Montouri. (1999) "U.S. Spatial Income Convergence: A Spatial Econometric Perspective,” Regional Studies, Volume 33, Number 2, pp. 143-156.

Rodrik, D. (2000) "Institutions for High-Quality Growth: What They Are and How to Acquire Them," Studies in Comparative International Development, Volume 35, Number 3, pp. 3-31.

Skocpol, T. (2002) Civic Transformations and Inequality in the Contemporary United States: A Review of the Literature, Mimeo, Boston, MA: Harvard University.

Sobel, J. (2002) “Can we Trust Social Capital?,” Journal of Economic Literature, Volume 40, Number 1, pp. 139-154.

Stanfield, James Ronald and Jaqueline B.Stanfield (1997) "Where Has Love Gone? Reciprocity, Redistribution, and the Nurturance Gap,” Journal of SocioEconomics. Volume 12, Number 1, pp. 106-129.

Timberlake, J.M. (2000) Racial and Ethnic Inequality in Childhood Exposure to Neighborhood Poverty and Affluence, Paper presented at the 2002 Annual Meeting of the Population Association of America: Atlanta.

Uslaner, E.M. (2002) Inequality, Trust and Civic Engagement. New York: Russell Sage Foundation.

Walker, Alexis. (2004) “A Symposium on Marriage and Its Future,” Journal of Marriage and Family, Volume 66, Number 4, pp. 843-847.

Wolff, Edward. N. (2001) "The Recent Rise of Profits in the United States," Review of Radical Political Economics, Volume 33, Number 3, pp. 315-324.

Woolcock, Michael. (1998) "Social Capital and Economic Development: Toward a Theoretical Synthesis and Policy Framework," Theory and Society, Volume 27, Number 2, pp. 151-208.

Yamagishi, T. and M.Yamagishi. (1994) "Trust and Commitment in the United States and Japan," Motivation and Emotion, Volume 18, Number 2, pp. 129-166.

Zak, Paul J. and Stephen Knack. (2001) “Trust and Growth,” The Economic Journal Volume 111, Number 470, pp. 295-321.

\section{Further reading}

Aglietta, Michel. (1998) "Capitalism at the Turn of the Century: Regulation Theory and the Challenge of Social Change,” New Left Reviews, Number 232, pp. 41-90.

Bowles, Samuel, David M.Gordon, and Thomas Weisskpof. (1990) After the Wasteland: A Democratic Economic for the Year 2000, Armonk, NY and London: M.E. Sharpe.

Gordon, David M. (1998) Economics and Social Justice: Essays on Power, Labor and Institutional Change. Edited by Samuel Bowles and Thomas E.Weisskopf, Cheltenham, UK and Northampton, MA: Edward Elgar.

Kotz, David M., Terrence McDonough, and Michael Reich, (eds) (1994) Social Structures of Accumulation: The Political Economy of Growth and Crisis. Cambridge, UK: Cambridge University Press.

Lippit, Victor. (1997) "The Reconstruction of a Social Structure of Accumulation in the United States,” Review of Radical Economics, Volume 29, Number 3, pp. 11-21.

Wolfson, Martin. (1994) "The Financial System and the Social Structure of Accumulation," in

David M.Kotz, Terrence McDonough, and Michael Reich (eds). Social Structures of Accumulation: The Political Economy of Growth and Crisis, Cambridge, UK: Cambridge University Press, pp. 133-145.

Yaghmaian, B. (1998) "Globalization and the State: The Political Economy of Global Accumulation and its Emerging Mode of Regulation," Science and Society, Volume 62, Number 2, pp. 241-265. 


\section{0 \\ Post neoliberal governance for sustainable global growth and development}

\section{Introduction}

Subdued long-term economic performance and financial instability are typical of the recent experience of much of North America, Europe, Japan, Latin America, Eastern Europe, the Middle East, and especially Africa — and hence global capitalism. The major industrial countries of Europe, the United States, and Japan continue to undergo long wave downswing characterized by periodic deep recession and major financial crises. The transitional economies of Eastern Europe-especially the largest, Russia and the Ukraine-have still not seen a recovery of real GDP (gross domestic product) to 1990 levels. A combination of financial crises, problematic performance, and spreading AIDS impact on many nations of (especially) Latin America, Sub-Saharan Africa, and Eastern Europe. Also, terrorism, war, and socioeconomic instability are impacting on most of the world, including the Middle East where economic conditions have been disappointing and conflict increasing. The contradictions of the global political economy are thus considerable in the light of these multiple problems, and hence a new global social structure of accumulation (SSA) or mode of regulation (MOR) is not in sight.

The major bright spot is much of East Asia, including China, Taiwan, South Korea, and South-East Asia-despite a major financial and economic crisis for many of these nations in the late 1990s. East Asia appears to be undergoing a long wave upswing while most of the rest of the world is subdued, looking at the situation from a longer-term perspective. To some degree, parts of East Asia (especially China, the Philippines, and Indonesia) act as producers of low priced consumer goods for much of the rest of the world through various commodity production chains. Other parts of East Asia (especially South Korea, Singapore, and-for decades now—Japan) have moved up the pyramid of economic power to produce more high-technology goods through buyer and producer production chains for much of the world, in competition to some degree with the West. China is moving up this pyramid rapidly. Economic activity is moving East, and this trend is probably long term, so that within 50 years China (and its archipelago) is likely to be the new hegemonic power, while much of East Asia undergoes a long wave upswing into the foreseeable future through a viable regional SSA or MOR.

This book so far has examined in some detail institutional aspects of global disarray into the 1980s, 1990s, and 2000s. The main conclusion is that the global political economy has not moved into long wave upswing for sustainable growth and development into the twenty-first century. The contradictions of the Global System of Power and Accumulation are strong as the positive aspects of the system are unable to push the negatives into favorable territory. The positives are rapidly growing FDI (until 2001), 
greater rates of innovation, and stronger competition. However, these positives are inextricably linked with and dominated by the negatives-greater conflict between East and West, lower incentive to invest, high levels of trade reform conflict, unproductive government spending, greater conflict between industry and finance, and declining levels of trust, equality, and stability.

The purpose of this chapter is to present a perspective and a series of governance measures that are designed to stimulate long wave upswing in the global political economy. The first section highlights the major problems besetting the global political economy as examined in the earlier chapters. In the next section a governance perspective is outlined to set the scene for the policy framework presented. Then the measures themselves are detailed for a post neoliberal system of governance.

\section{Problems in the global political economy}

Instability, conflict, and discontinuity are strong in many areas. A global neoliberal SSA is insufficiently developed. The limits of neoliberalism are multifarious. In general, it creates social forms that tend to lack sufficient demand, trust, and sociality. More specifically, it has continued the trend of transferring government activities from productive to unproductive pursuits. Declining relative productive spending on government initiatives in communications, infrastructure, health, and education led worldwide to greater unproductive activities such as expenditure on the military, consumer goods, and handouts. Governments in general failed to spur private investment through the crowding in process. With the dominant policy being monetary-utilized by central banks - governments increasingly found it difficult to influence economic activity in their own right. Deteriorating work conditions and real wages led to a population of over-workers and under-earners. Together these factors resulted in global stagnation of aggregate effective demand through declining investment and productive government spending (see Chapter 3).

Transnational corporations (TNCs) are failing to establish even minimally reasonable rates of profit, due to continental limits to the expansion of the market. A global TNC SSA is also insufficiently developed. This is because conflicts and instabilities prevent the expansion of the circuits of capital. Crowding out of domestic investment by FDI is quite strong in Latin America, much of Eastern Europe has not even reestablished growth and investment levels of 1990, and Africa is outside of the growth path of transnational capital. North America and Western Europe were in the doldrums during 2001-2003. Competition is too strong and innovative rents too weak to propel long-term global profit and accumulation. This is a critical weakness of the global system as transnational are a potentially major force for global recovery, yet they are generally lacking a positive longterm accumulation dynamic, despite the emergence of a (short) business cycle upswing in the global economy after the recessions of the early 2000s (see Chapter 4).

A global mode of regulation is not suitably operational. The global regime of accumulation is unable to establish reasonable levels of demand and productivity to spur growth and development due to system irregularities. Much has been made of the globalization trend fueling innovation and competition, and thereby presumably reestablishing higher levels of performance. Except for parts of Asia, however, this is 
simply not occurring in a long-term sense. Much is made of the trend to flexibility, such as the deepening of just-in-time methods, total quality management, and information and communications technology. The record of economic growth, demand, and productivity is not pretty, however. The incentive for investment is relatively low. The main problem appears to be global insuificiency of demand since the main trend is for cutting costs and propelling corporate mergers and reorganization. Investment in plant and equipment is not sufficiently forthcoming, which reduces productivity, innovation, and the penetration of foreign markets (Chapters 5 and 7).

The multilateral system of trade is in disarray. Little progress has been made in the typically three-pronged lengthy procedures within the WTO (World Trade Organization) of (a) discussions, (b) resolutions, and (c) actions in the early years of the new millennium. There is a conflict between the developed and undeveloped world inasmuch as poor nations of the world are being hindered by large agricultural subsidies and other supports, especially by the United States and some other industrial nations. They are not being given a chance to develop agriculture through an unfair trading system that supports the vested interests of farmers and producers in the core rather than the periphery. There is also conflict between Europe and the United States over rules of investment and whether nations or areas have the right to protect themselves from large transnational that have a lot of power in the world economy (Chapter 5).

The financial system has been subject to major speculative bubbles and uncertainty with major conflict between business and industry. During the 1990s- early 2000s hot capital instability was a critical problem in the global economy, especially for crisisridden emerging or developing nations. Some measures were instigated to potentially moderate this problem, while the conflict between industry and business continues to plague regional domestic economies that are following the institutional trends associated with the United States. Instability is high because speculative bubbles have become institutionalized into the fabric of deregulated economies. Conflict is high between finance and industry as the returns to investment are biased against productive activities. Profitability and productivity in the financial system is problematic as risk is high and deregulation has not brought the alleged benefits promised (Chapters 5, 7, and 8).

Terrorism, and the war on terrorism has itself led to major uncertainties and disarray globally throughout especially the United States, Europe, the Middle East, Asia, and Oceania. This has hampered a global military SSA. The inability of the major powers to prevent the rise of Islamic militants and radicals-after the demise of the Soviet-style system-led to a new threat to global growth and development. One of the problems is that there has been a confusion between fighting radical Islam and ridding ruthless military rulers such as Saddam Hussein from positions of power. Another is that the radical Islamists are against US hegemony in the Middle East, while the United States only strategically supported them against Russian control in places such as Afghanistan. There is a major rallying against the United States in the Middle East and this dampens the global power of capital through higher levels of uncertainty (Chapter 6).

To this point we found that the Global System of Power and Accumulation was not instilling long wave upswing type institutional arrangements into the sociopolitical economy. Next we sought to examine the extent to which the US System of Power and Accumulation may be leading the world into a potential phase of sustainable growth and development in the early decades of the new millennium. The next three chapters, then, 
examined the US System of Power and Accumulation. Chapter 7 scrutinized the regime of accumulation, paying attention to the extent that productivity and demand are emerging as sustainable forces. Productivity and aggregate demand, however, were shown to have major problems, and were not advanced enough to act as role models for the world economy. Much of the productivity advance of the early 2000s was due to shedding labor, and less conspicuous was the role of ICT-induced advances (Chapter 7).

Then the power of the US financial system was analyzed on the basis of whether there is sufficient stability, conflict resolution, and performance. The stockmarket was shown to be subject to considerable periodic speculative bubbles that reduce efficiency in the distribution of the economic surplus. A wealth generation-consumption process that is dependent upon stock market returns and fictitious capital is likely to incur major instabilities and uncertainties. The conflict between industry and finance was shown to be of a high order, since during the 1980s and 1990s there was little relationship between equity growth and production growth. The wholesale deregulation of the financial system has thus led to a periodic escalation in the growth of unproductive capital as the power of finance has grown relative to productive industry. This seems to have happened in all major economies that have followed the US neoliberal lead, including the United Kingdom, France, and others. The banking system also does not seem to be operating very efficiently, since productivity has been low, profit variable and subject to greater risk, and customer service has deteriorated significantly. Overall, a new financial SSA thus has not emerged for sustainable growth and development (Chapter 8).

The power relations associated with the deepening of the "market society" has been a source of anomalous community and familial relations through higher levels of distrust, inequality, and dislocation. The last few decades of neoliberalism and globalization have resulted in a breakdown of social relationships as people have sought to look after their own interests rather than those of other people, and through the movement of reproductive activities from the family environment to the market. Individualism as a social philosophy and practice has deepened, negatively impacting on the social economy. Within the circuit of social capital is a realm of potential and necessary cultural linkages, trust and association that underlies much of the workings of capitalism. This breakdown of familial stability, trust, and relative equality has affected the system by reducing the health of children and the degree of democracy enthused by participation, while inhibiting those with potential but little capital from building productive business and community networks. There has been greater unproductive use of time getting to work, the stress of working more in an unfavorable climate, and greater noise and environmental pollution in everyday lives. This has led to working and middle class communities deteriorating, propelling greater alienation, boredom and isolation, as well as higher transaction costs of social interaction, reduced investment, and an expansion of systemic instability. These tendencies of an insufficiently developed family-community SSA are likely to go beyond just the United States, as many other economies seem to be following their lead to some degree (Chapter 9).

These multiple instabilities and conflicts demonstrate the operation of very fundamental contradictions for global capitalism. For many authors the positive dynamic elements associated with FDI, mergers and acquisitions, innovation, and demand-driven commodity chains have blurred their perspective. There is no doubt that the positives-or at least forward-looking elements-are considerable. To ignore them is to abstract from 
many of the interesting aspects of the contemporary world. However, as this study has demonstrated, rose-colored glasses are no substitute for a balanced, critical analysis of the operational dynamics of the system. Indeed, critical analysis is fundamental to comprehending the complex operations of global trends and dynamics. Without it, no real foundation exists for devising a long-term governance plan for the near-and-distant future. Having a vested interest in a positive depiction of the story is ultimately deceptive and does not provide a proper picture of the major trends and stylized facts at play. It is with this in mind that we turn to issues of governance.

\section{From neoliberalism to post neoliberal governance}

The governance measures supported in this chapter accord with the current move toward a "post Washington consensus" (PWC), even though it to some degree moves beyond this new trend. We need to thus look briefly at the nature of the Washington consensus (WC) and its relationship to neoliberalism and the PWC. There are two versions of neoliberalism and the WC. The first is a "popular" perspective that was to some degree operationalized through Reaganomics, Thatcherism, and like-minded contemporary adherents and policymakers. This was the version emphasizing the privatization of government functions, deregulation of labor, commodity and financial markets, and the balancing of the budget (or at least reduced taxes). The emphasis here was on reducing the role of government and reestablishing market functions in most areas.

However, there is a second trend linking the term "Washington Consensus" specifically to John Williamson (1990) in the light of the Latin American "failure" of high government, import substitution, and rent-seeking activities through the 1970s and early 1980s. Williamson coined the term "Washington Consensus" as a set of policies that Washington institutions such as the IMF (International Monetary Fund), the World Bank, and the US government were broadly in favor of for Latin America. Briefly he specified the policies as including:

- Fiscal discipline

- Productive government spending

- Tax reform to lower rates and broaden base

- Interest rate liberalization

- Competitive exchange rates

- Trade liberalization

- External capital flow liberalization

- Privatization

- Deregulation

- Promoting property rights.

There has been some debate about whether all of these measures were really in consensus at the time, and Williamson (2000) himself has critiqued some of them openly as being improper reforms. Certainly he distances the WC from neoliberalism as popularly termed- "Liberalize as much as you can, privatize as fast as you can, and be tough in monetary and fiscal matters” (Kolodko 1998). For him, the WC was an intelligent and fair assessment of the situation, and had no real fundamentalist ideological underpinnings 
as such. But the reality is, of course, that the WC was mostly linked in practice to the popular neoliberal agenda, and it is certainly the case that most of the points mentioned earlier link closely to the neoliberal agenda.

It is no surprise, then, to find various forms of the PWC, some of them evolving from the original WC view (Williamson 2000), some making an economic break from the WC (e.g. Stiglitz 1998), and some of them being a more political and social critique of the WC with a broader agenda (Gore 2000). All of them, though, would have taken as a point of departure a critique of the simple 10-point list shown above. Essentially, these versions of the PWC reject the simple-minded idea of fiscal discipline in favor of a pragmatic adjustment of spending and taxing depending on the economic conditions. They recognize that neoliberalism (the popular WC) failed to emphasize productive government spending, instead simply arguing for a cut in state activity. They also acknowledge that financial deregulation encouraged unproductive activities and shady financial dealings. Liberalization of capital inflows is strongly attacked as promoting hot capital flows and crowding out of domestic investment by FDI in some regions. Wholesale privatization is said to often lead to the transfer of ownership to private rent seekers and monopolies.

It is mostly in these areas that the PWC-in its many varieties-challenges neoliberalism and is currently evolving to some degree as a potential consensus view in development and policy circles. Taken as a whole, the problems of the 1990s questioned the basic assumptions of neoliberalism and the WC-the established governance paradigm. Sometimes the challenges were subtle and at other times more obvious. In part, the challenges constitute a more sophisticated version of neoliberalism, one that recognizes limits to markets and the free play of market forces. In general, though, the new vision constitutes a fundamental rethinking of policy in the light of the recent instabilities, conflicts, and uncertainties and the reemergence of old themes such as institutions, social fabric, endogenous processes, and circular and cumulative causation.

Some analysts, such as Ben Fine et al. (2003), seek to critique and go beyond both the WC and PWC frameworks as being essentially closely related and economistic in nature. There is some truth to his argument. He takes the Joseph Stiglitz version as being the essential PWC, arguing that he is following the WC perspective but makes it a little more realistic and pragmatic in approach. Calling him a "left-wing neoliberal," Fine argues that Stiglitz's approach is narrow and confining, reductionist in the sense of concentrating on market imperfections associated with asymmetrical information, and fails to include notions of class, power, history, and society which are critical to a "progressive" development perspective. Stiglitz's framework is said to be utilized in policy circles to reestablish conservative and orthodox arguments where the old fundamentalist neoliberal edifice is no longer viable.

However, Fine doesn't emphasize sufficiently that the Stiglitz argument is an advance on neoliberalism (see especially Stiglitz 2002a), and that there are other influences evolving within the PWC more in line with a political economy view of development. For instance, Charles Gore (2000) puts forward a PWC view that includes the sustainable human development approach of the United Nations and Amartya Sen's capabilities theory. These influences aim at improving people's lives through more participatory and poverty-reducing programs. It also recognizes the role played by both basic needs and expanding capabilities through micro credits, education and health promotion. 
Gore also includes in the PWC the "Southern consensus" which has some impact on policy. This is an alliance between Latin American structuralists and Asian developmentalists, who recognize that history and structural environment make a good deal of difference to development. Sequencing of structural changes is important, and state-business linkages to direct long-term productive capital through industry policy, provision of infrastructure and innovation, and regional cooperation and integration. This represents a form of strategic governance where national economies link to regional and global structures and commodity chains, and where those networks inform governance issues and policies. Such policies look to long-term trends and evolutionary transformation in global and regional economies.

The new consensus - of whatever variety - is also associated with a recognition of the role of institutions and trust in the development process. The World Bank, in particular, has championed the notion that institution building is both a pre- and co-requisite for development and that structures of trust and association are essential for markets and other institutions to operate effectively. It is not simply a question of property rights, but also the rule of law, reducing corruption and promoting political stability, accountability, and community (Schweickert and Thiele 2004). Government regulations and policies need to be imbued with forms of trust and community participation, as well as accountability, effectiveness, and proper delivery of services. Private sector institutions such as corporations need to separate auditing from financial advice, link CEO remuneration to long-term performance, and be more cognizant of the collateral requirements underlying debt accumulation.

In this broader PWC, Gore concludes that:

The most likely prospect is that we shall be blown into a future facing backward, embracing a form of embedded communitarian liberalism, which seeks to reconcile the achievement of national, regional and global objectives, and to marry universal values with a respect for diversity.

(2000:801, emphasis added)

I would thus agree with Fine about the need for a more "political economy" approach than the PWC as outlined by Stiglitz, but to some degree he underplays the degree to which some of the frameworks included in versions of the PWC are likely to play a progressive role in promoting long wave upswing in the near-term and longer policy horizon. For this reason my own framework of governance is looked upon as having many similarities to the PWC, even though it ultimately goes beyond this to some degree. ${ }^{1}$ Instead, therefore, it is called "post-neoliberal governance” (PNG), since to call it a consensus is perhaps pushing the argument too far at this stage. ${ }^{2}$

In subsequent sections we thus detail five broad PNG measures that could promote long wave upswing in the global political economy. The method used will be to concentrate on measures to reduce unproductive activities that heighten conflict, instability, and disarray in the institutions. We start with an investigation of the need for a holistic global perspective on growth and development, including the need for successful industry policy for value added activities. Then we go on to outline a philosophy of government around productive activities and a pragmatic framework of finance. The need to resolve the conflict between industry and finance is then analyzed vis-à-vis Tobin 
taxes, restructuring the global financial architecture, and domestic means of moderating speculative bubbles. Measures relating to terrorism and the war on terrorism are explored in relation to public awareness, technology, regulation, and global cooperation. And finally the question of restoring familial and community trust, equality, and social stability in the long run are examined. It needs to be recognized that these measures should be ingrained into the institutional fabric in a way that does not dislocate existing positive structures of association and interaction (see Bush 2001). There are also regional and local variations to the policies suggested here for this PNG, which should be kept in mind throughout. ${ }^{3}$

\section{Governance policies 1: holistic growth and industrial development}

The period of neoliberal cutbacks has seen an emphasis on supply rather than demand, the assumption being that if costs are low and prices are right, private investment will be forthcoming. This ignores the reality that declining labor share and conditions, increases in inequality, reductions in tariffs and industry assistance, and limits on government spending have reinforced a major barrier to growth. In a Kaldorian world of circular and cumulative causation, aggregate demand links more holistically to supply via the propulsion of investment, innovation, and productivity. This occurs through economies of scale and scope, learning by doing, innovation, and the subsequent penetration of export markets. Manufacturing and high-technology commodities are given a privileged position in this framework. Such a perspective requires a fundamental rethink of governance issues as well as the way in which the economy operates.

In a world of circular and cumulative causation, aggregate demand needs to be fostered through a reduction in uncertainty, which can stimulate investment and consumption. Uncertainty can be lowered through promoting greater financial and social stability via restoring the role of workmanship over finance, propelling poverty reduction schemes through productive government spending and automatic stabilizers, and enhancing learning and innovation through the expansion of human and social capital. This requires recognition that the economy is a complex adaptive system where the central processes are interdependent and systemically linked, and where socioeconomic reproduction has a major impact on growth and development.

Our analysis of the large corporation posited a number of problems leading to low profitability, investment, and productivity. Despite the massive global increases in FDI over the past 2 or 3 decades, national investment strategies in many continents were a failure in the 1990s-2000s. The primary problems are a relative lack of investment of any sort in Sub-Saharan Africa; the inability of many Middle Eastern nations to reinvest the oil surplus productively for long-term performance; a degree of crowding out of domestic private investment by FDI (especially) in Latin America; the dislocation of Russian and Ukrainian productive structures by the deregulation and privatized tendencies; and the unstable flow of global FDI, such as the crash of 60 percent during 2001-2003. In addition, the mature economies of the United States and Western Europe underwent financial instability and recession, and a movement of economic activity to Asia. The only region to experience what could be seen as long wave upswing (of a sort) is that of East and South-East Asia (see O’Hara 2005). 


\section{Encouragement of productive FDI}

The crowding out of FDI in Latin America seemed to be related to the open slather approach that most of the governments there have to foreign investment. After deregulating and privatizing many of their institutions in the 1980s and 1990s, any sort of FDI was encouraged, irrespective of the impact on local investment. Very little of the FDI, as a result, was put into Greenfield areas of plant and equipment, new technology, and R\&D (Research and Development), much of the profit being repatriated overseas, and many of the local firms being put out of business due to overseas competition. What is required, it seems, in developing nations is an alternative policy framework, which is developed in the following section.

One general governance measure that can be put into place-similar to those in Asia-is to encourage FDI that is long term and productive in nature and where the profits are regenerated back into the domestic economy. Three associated policies may be useful here. Companies that spur such positive investment may be given a tax break, and/or R\&D incentives, and/or government assistance through infrastructure injections. Such policies could be operationalized after an annual investigation of FDI flows over the past few years, and the companies that promote long-term multipliers and accelerators.

\section{Policies to develop high-value-added industries}

An understanding of the position of Sub-Saharan Africa, the Middle East, and Latin America can be gained through commodity chain analysis. As Peter Dicken (2003) demonstrates: Sub-Saharan Africa constitutes no meaningful part of the global commodity chains, while that of Latin America is heavily tied to the United States, and the Middle East to that of oil. These areas of the world have little investment in global production networks, including few linkages to the dynamic structures and processes of business alliances and relationships in the global economy. Most of these areas have few human, innovative and network capitals, while Sub-Saharan Africa, Latin America, and South Asia suffer from problematic terms of trade.

A critical problem has been the tendency for the terms of trade to decline for primary products such as agricultural goods, metals, mining, and even low-value-added manufactures. This problem, called the Prebisch-Singer hypothesis, has been further supported over the past 30 years as inhibiting the growth and development of especially Sub-Saharan Africa, Latin America, and parts of South Asia. David Sapsford and V.N.Balasubramanyam (1999), for instance, argue that both trend and volatility are significant in the terms of trade. Over the twentieth century, relative primary product prices (compared to manufactured goods) have declined by about 40 percent, while the cyclical instability problem has become very significant. Some authors concentrate on trend while others emphasize structural breaks. Either way, the periods of major decline and instability have been during long wave downswings- the 1920s-1930s and 1970s1980s (see Cuddington et al. 2002; Ocampo and Parra 2004).

Over the 100 years from the early 1900s to the early 2000s, price instabilities have beset most commodity prices, with declines being especially marked for copper, jute, maize, aluminium, cocoa, cotton, tea, silver, wool, hides, lead, rice, sugar, and wheat. Substantial price increases were characteristic of lamb, timber, tobacco, beef, and coffee. Typically, “tropical” agricultural products declined considerably while "non-tropical” did 
not (Ocampo and Parra 2004). Overall, the commodity terms of trade $-P_{\mathrm{p}} / M_{\mathrm{p}}$, the index of primary product prices divided by manufactured goods prices - has declined significantly over the period. As a result, the net barter terms of trade $-X_{\mathrm{p}} / M_{\mathrm{p}}$, the index of export prices divided by import prices - declined in average annual growth terms by 0.50 percent for the poorest nations of the world; there was zero growth for medium income nations; and annual average growth for high income nations was 0.23 percent (Lutz 1999:862). Critical problems are the relatively low world income elasticity demand for primary products, the introduction of alternative synthetic fibers in the North, and the static view of comparative advantage that reinforces the reproduction of relatively unproductive sectors and activities.

In terms of policy, Sapsford and Balasubramanyam (2003) critique the IMF and World Bank structural reform agenda which advised African nations to increase their exports of (non-processed) primary products. They argue that this advice is subject to the fallacy of composition that a partial equilibrium solution for some nations is consistent with a general equilibrium solution for all such nations. Clearly, if all African nations export more primary goods, their terms of trade are likely to get worse.

\title{
Industrial development policies
}

It is important to develop a decentered policy of variously enhancing the export of products whose terms of trade is increasing, organizing cartels for suitable products whose price can be stabilized, and more generally:

\begin{abstract}
It has become clear that the downward trend in the prices of commodities and even in the prices of developing countries' manufactured exports is one of the factors contributing to the divergence in levels of development at the world level.... Today, as in the past, industrialization seems to be the only way out for developing countries as a group, but the available evidence also indicates that they will reap greater benefits from this process if they manage to penetrate the market for technology-intensive manufactures.
\end{abstract}

(Ocampo and Parra 2004:26, emphases added)

Developing nations need to transcend their dependency upon low-value-added agriculture, mining, and manufactured goods. The development of programs to built knowledge, infrastructure, networks, and financial assistance could in the long-term promote such sectoral change and development. The policy programs of the Latin American structuralists and Asian developmentalists will be instructive here. A suitably reformed state needs to be used for propelling industry policy, education, and global trade reform. State spending for the promotion of dynamic comparative advantage is necessary, where secondary and technological structures are built that transcend many of the lowvalue-added practices. The private sector tends to underproduce the long-term public goods of agglomeration, knowledge, technology, skills, trust, and stability. As Wolfram Elsner (2003) argues, this is due to coordination problems associated with uncertainty, asymmetrical information, insufficient learning, ceremonial encapsulation of knowledge, centralization, and insufficient institution-building. 
Ha-Joon Chang and Ilene Grabel (2004:77) argue that the success story of East Asian nations such as Japan, South Korea, and Taiwan can provide a window of hope for developing nations of Africa, Latin America, South Asia, and the Middle East. Much of this relates to their use of industry policy. Fred Robbins (2002) demonstrates that the East Asian industry policies of the 1950s and 1960s do need to be modified somewhat in the light of the recent trend of globalization, but that they are still very much in use in the area, and could (with modifications) be adapted to other continents and nations quite successfully.

While certain general traits of industry governance may be utilized, Chang and Grabel argue that "there is no single template for selective industrial policy across developing countries," but certain steps are required that particularize the policy requirements of specific areas. Hence, the first step is "the design of an overall 'development vision' for the country" (or region), where the resources and potentialities of the area are linked to more general market and institutional environments. The second step is to design specific policies facilitating industry development. The third step is to "design...clear performance targets and incentives” relating to local content, R\&D potential, and importexport mixes. Such policies are much more likely to succeed where there are "appropriate mechanisms of accountability, performance review and monitoring progress” (p. 76); or as Robbins says, future policies need to be transparent, nondiscriminatory, internationally acceptable, beyond cronyism, globally minded, and without crude mechanisms for maintaining local content (p. 306).

Recent empirical studies may give some insight into how the "development vision" may be formulated. For instance, a multifarious policy is necessary which includes government productive spending on activities that crowd in private investment, targeted and general R\&D support, indicative investment planning and regulation, and coordination of industry investment. Government spending can be used in the most productive fashion by financing infrastructure spending on roads, bridges, pathways, communications, and energy development. This helps provide the social overhead capital required for community and industrial network formation. Then a major boost to human capital is likely necessary in the areas of primary, secondary, and tertiary education, along with preventative and mainstream health in local communities and hospitals.

Important is the promotion of networks through university-corporate collaboration on R\&D. The global trading system needs to be reformed to provide positive benefits to promote exports and commodity chain linkages through the world economy. Specific industry assistance will likely be required for (a) supporting technology sectors that have a special regional or niche advantage in the long run (a high priority), (b) developments in technology for expanding the fabrication and manufacture of agriculture and mining into higher value-added areas, as well as (c) the deepening of information and communications technology. This does not just involve "picking winners" but also providing general encouragement and finance to open up new areas of innovation, often through market-type incentives. As Joseph Stiglitz argues:

Modern industrial policy is often "broad gauged” and, so far as possible, attempts to employ market like mechanisms in implementation. Thus, it may make more sense for the government to encourage "energy efficient technologies," allowing competition among alternative approaches [...] In 
this competition, it may require those seeking support to contribute substantial amounts of their own, so that their own money is at risk as well as that of the government. Similarly, in loans (such as those for small and medium sized enterprises) the government may use commercial banks to help screen applicants, but require the originating banks to risk some of their own capital. In science and technology projects, peer review should be employed.

(2002b:20)

Part of the process of industrial development could be promoted through tariffs for the promotion of infant industries. Dominick Salvatore (2004:287) emphasizes that infant industry protection is one of the few forms of protection that "stand up to close scrutiny," and that there are good arguments for implementing temporary protection for developing nations during "infancy" until it can meet foreign competition, achieve economies of scale, and reflect the nation's long-run comparative advantage” (emphasis added). Tariffs are likely to be better means of protection because they need few initial outlays and are acceptable to the WTO for poor nations (Chang and Grabel 2004).

\section{Governance policies 2: proactive and productive governments}

Apart from developing a more holistic and long-term perspective on social and industrial development, it is necessary for PNG to promote a more productive and pragmatic approach to public finance. Industry policy is inextricably linked to developing a more proactive and productive role for government in order to complement private sector development. Emphasis should be given to promoting government activities that propel long-term private investment, growth, and development. Along with this is the need to develop a new philosophy on public finance that is consistent with the new evidence of the workings of the budget constraint, recognizing the complexity of the institutional environment, and taking a pragmatic approach to stabilization policy.

\section{Expansion of productive government spending}

A large number of studies over the past 10-15 years have investigated the degree to which public spending impacts on private investment and growth. In general, the conclusions are pretty consistent that the spending that enhances private investment is that on infrastructure, education, health, transportation, and communications. Spending that crowds out (or has no effect upon) private investment tends to be activities relating to the military, welfare, and subsidies. The policy recommendations are that the neoliberal (and welfare state) tendency to cut productive government spending needs to be reversed. Also, it is typically the case, due to the budget constraint, that tax-financed government spending crowds out private investment, whereas debt and money-based deficits crowd in private investment.

For instance, a representative sample of these studies, summarized here, come to the following conclusions, for particular areas and nations:

- International evidence (39 nations): Public expenditure on welfare, social security, and subsidies crowds out, whereas spending on transportation and communications 
(developing nations) and health and education (developed nations) crowd in private investment. Due to a liquidity constraint, tax-financed government spending crowds out whereas deficit financed spending crowds in private investment (Ahmed and Miller 2000).

- International evidence (between 74-95 nations): “Government investment does indeed appear as an important factor in growth, with a significant estimated coefficient in most specifications.”...“Government investment has been severely suboptimal in [the] recent international experience and...scope remains for greater productive expenditures by the government sector” (Miller and Tsoukis 2001:1125).

- Malaysia: "Crowding out effect of tax-financed expenditures is higher than that of debtfinanced expenditures.... Thus far, our analysis provides justification for the increase in development expenditures financed by deficits.... These results are intuitive as... [current expenditures, such as transfer payments, pensions, general administration charges]... are unproductive in nature while [development or capital expenditures] which include spending on transport, telecommunications, education and health are productive investments” (Ibrahim 2001:196-197).

- United States: The post 1970 slowdown in economic growth can be totally (in fact over) explained by the large shift in fiscal policy from government purchases towards transfer payments. If policymakers are serious about growth then they need to promote productive spending, especially on infrastructure such as roads, communications, transportation, education, and health (Weber 2000).

- Europe: Privatization has resulted in a decline in productive government spending, whereas an increase in such spending crowds in private investment in Ireland, Portugal, and Greece. The marginal product of public capital is high, and contributes to substantial scale economies in providing public goods. This is especially the case for preprimary, primary and secondary education; hospitals, clinics, practitioners, medicaments, and prothesis; but also to some degree housing, recreation and cultural services, and transportation and communication. Military spending, on balance, has no impact on private investment (Laopodis 2001).

The neoliberal philosophy, ironically, has resulted in the selling of productive government enterprises, and a redirection of spending to low impact projects. Thus while trying to make government "more productive," neoliberalism has had the opposite effect through reducing the power of the public sector. Post neoliberal governance recognizes that privatization of government activities may lead to suboptimal results due to declining public goods and an expansion of private sector rent-seeking behavior. This is of critical concern for developing nations to propel a take off in investment and innovation for sustained growth and development, but the results also apply to advanced nations (Aschauer 2000). ${ }^{4}$

This leads us to consider the role that government can play in enhancing aggregate demand, supply, and reducing uncertainty. One thing that stands head and shoulders above other factors is the role that can be given to productive government spending in enhancing business investment. Such productive spending contributes directly to production and innovation through government corporations and departments enhancing leading-edge activities in communications technology. It also contributes indirectly through the advancement of knowledge, health, transportation, and the flow of goods and services. Positive externalities are especially strong through agglomeration benefits in the 
form of the public goods of circulation, information, skills, knowledge, and longevity. The new vision recognizes these potentially greater advantages of providing such public goods.

\section{Functional finance policy}

Functional finance - initially developed by Abba Lerner in the 1940s - is important to the post neoliberal perspective because it takes a pragmatic approach to fiscal and monetary policy. Functional finance contradicts the "sound finance" doctrine, which stipulates that, regardless of economic conditions, the budget should be balanced in the long run and government should not spend more than it collects in taxes. For sound finance, the maintenance of balance budgets over the cause of the business cycle is said to increase prosperity and remove excessive debt burden on future generations (O'Hara 2000). In contrast to this orthodox view, the central idea of functional finance is that fiscal policy, in all its different aspects - taxing, spending, transfers, borrowing, printing money, etc.should be undertaken not for financing government budgets but to achieve specific economic objectives, such as full employment. For instance, should total spending be lower than the full employment level, the economy will experience "unnecessary unemployment.” If an increase in spending does not increase inflation significantly then the economy has obviously not reached full employment. ${ }^{5}$

There are two "laws" of functional finance. The first is that governments have a responsibility to keep the total rate of spending on goods and services "neither greater nor less than that rate which at the current prices would buy all the goods that it is possible to produce" (Lerner 1943:39). Associated with this is the notion that taxation should never be undertaken "merely because the government needs to make money payments.... Taxation should therefore be imposed only when it is desirable that taxpayers shall have less money to spend" (Lerner 1943:39). The second law of functional finance says that "the government should borrow money only if it is desirable that the public should have less money and more government bonds" (Lerner 1943:39). Taxes regulate demand in the economy and bonds are necessary to regulate interest rates.

A change in policy perspective along the lines of functional finance will introduce more pragmatic policymaking rather than the fundamentalism of neoliberalism. It will ensure that policies are instituted that are historically situated in the problems that emerge in the social economy. It will also enable policies that center more on social objectives and outcomes, in the context of changes along the business cycle.

\section{Taxes-drive-money approach to policy}

The neoliberal theories of fiscal and monetary policy are problematic. For this reason a new approach is required, one that recognizes the need to adopt more productive government schemes as well as to adjust spending to changes in economic activity through business cycles and long waves. Consistent with the given emphasis on productive government spending and functional finance is the Chartalist view about how government fiscal and monetary policies operate. That is, the use of taxes and borrowing are not used to finance government spending, but to moderate levels of reserves in the economy and thus affect the level of aggregate demand. Increases in taxes reduce the 
level of potential private spending, while reductions increase the level of private spending. Government bonds are used to put into practice open market operations through changes in official interest rates. Government spending is financed through fiat money, since when the state spends it writes a check on its account with the reserve bank, thus increasing bank reserves (Bell 2000). Hence, fiscal and monetary policies are not as clear-cut as is usually assumed.

The main methods by which "state money" is injected into the economy are via government spending on goods and services and transfer payments. Once the government spends and injects its own state money into the economy it is then available to be paid back to the government in the form of taxes (Wray 1998:80). Taxes are thus required to generate a demand for fiat money and are not required to finance government spending (Wray 1998:75). Bond sales are required only to drain excess reserves in order to achieve central bank interest rate targets. Thus, government outlays are not financed by bond sales and taxes, but by the creation of money or credit. Budget deficits thus do not normally (on balance, especially when "productive") crowd out investment or cause inflationary pressures because government outlays represent a source of funds for private spending.

The government is "normally" obliged to run a budget deficit in order to provide the state money to meet all tax obligations as well as meeting the hoarding needs of households and banks. Persistent government surpluses only reduce the amount of fiat money available in the economy; when there is public hoarding, persistent budget surpluses are a problem of demand inadequacy. Balanced or surplus budgets would only be considered when a serious level of inflation is expected. Otherwise, deficits are required for a reasonable level of profitability for the private sector. ${ }^{6}$

\section{Governance policies 3: balance between finance and industry}

Post neoliberal governance seeks to promote a balance between business and industry. One aspect of this is the balance between finance and industry. During the 1950s and 1960s, there was a strong link between finance and industry, but during the 1980s through the 1990s and 2000s, this linkage was severed to the extent that large speculative bubbles regularly developed and burst in many nations (Binswanger 2000). Regular financial crises emerged during the 1970s-2000s, especially during the 1990s-2000s, that were not typical of the earlier period. In the era of deregulation, finance is able to periodically innovate, leading to a period of rapid growth of financial aggregates as euphoria expands investment and cyclical upswing emerges. However, this tends to lead to overinvestment in certain speculative sectors and financial aggregates growing faster than revenue or dividends. Bubbles then lead to a financial crash and recession as uncertainty heightens and investment diminishes (Spotton Visano 2004). ${ }^{7}$

The 1990s and early 2000s were thus a period of extreme instability, culminating in the Mexican, Asian, Russian, Brazilian, Japanese, United States, European, Turkish, and Argentinian crises and recessions. Initially, for most of the crises in the developing or transitional areas, the IMF responded in their typical fashion of urging cuts in government spending, increasing interest rates and structural adjustment. But after they realized the problems of making rigid policy templates, the need to activate antipoverty programs and making the financial architecture more stable, it instituted reforms to 
enhance social stability, capital adequacy, transparency, information, and quasiinternational lender of last resort facilities. They recognized that premature deregulation and innovation can lead to irregular debt accumulation and unstable endogenous sources of credit. However, coming back to these reforms from a safe distance, it is perhaps unlikely that, in general, the IMF has fundamentally changed its neoliberal foundations significantly. ${ }^{8}$

The problem of financial instability continued through the 2000s in the West as the United States underwent speculative bubble boom and crash as well as corporate fraud and crisis through the Enron, Worldcom, and Corporate Crossing irregularities. Similar corporate crises occurred in other nations through Parmalat in Italy and HIH in Australia, for instance. Three problems were especially acute. The first was the excessive salaries and bonuses paid to chief corporate executives, both in general and in the aftermath of corporate failures. The second was the propensity of such companies to engage in excessive debt which was recorded as income since debt was undertaken through "external" institutions (that were in reality part of the parent company). And the third major problem was the politically encouraged practice through the 1990s of financial advisors also acting as auditors, which represents a classic conflict of interest.

These financial and corporate crises are related to the obvious conflict between finance and industry. Many studies have pointed to this conflict emerging through the 1980s, 1990s, and 2000s. In essence it is a question of power and emphasis. To what extent do corporate and governance cultures of nations, regions, and continents encourage the gaining of rents independent of productive work and innovation? Veblen (1919, 1921) saw it as a question of the vested interests of finance holding more power than the productive engineers, innovators, and workers who have to settle for a mere wage or modest salary. It is critical to promote the efficient allocation of resources to productive activities rather than to excessively speculative and privileged activities that waste the surplus and represent a (private sector) rent-seeking type activity. Recent US legislation has sought to moderate the conflict of interest between auditing and providing financial advice, ensure proper information about corporate debt, and also reducing executive salaries in the event of poor corporate performance (Munzig 2003). But it is unlikely that they have sufficiently dealt with the institutionalized anomalies of excessive corporate salaries, undue influence gained through lobbying congress and campaign contributions, corporate tax avoidance, and the distant memory of these events in the future making policy changes less effective (Klinger and Sklar 2002).9

\section{Global Tobin Taxes}

In the environment of global financial instability many have preferred the notion of a tax on the highly mobile and short-term flows of finance. The Tobin Tax is the most famous of these proposals, originally suggested by James Tobin in his 1972 Janeway Lectures at Princeton (Tobin 1974) and later elaborated in the pages of the Eastern Economic Journal (Tobin 1978). Many others have followed the general idea and often changed the nature of the objectives behind it. Tobin proposed it as a measure to promote global stability by moderating the excesses of financial capital, with perhaps the receipts being used by the national governments as required. He wanted to put "grains of sand into the wheels" of speculative and hot capitals to reduce volatility and dominance. Others have 
proposed the receipts be partly or wholly used as a global development fund to provide some combination of funding for continual development of poor nations and a lender of last resort facility (see Patamaki 2001).

Given the nature of the possible receipts from such a tax, and the potential for it to promote stability, this proposal may well function in such a combined fashion to aid global stability, growth, and development. For instance, it could be operationalized in the following way:

- Be levied on highly mobile, short-term, speculative financial transactions.

- At a variable rate of between 0.2 and 0.4 percent of the value of financial flows, depending on the nature of the flows (e.g. loans, futures, options, etc.).

- Be capable of being adapted through time to respond to attempts to evade or avoid the tax.

- Be implemented through the United Nations, the World Bank, or the G6, G7, or G8 or unilaterally (initially).

- With receipts being divided (depending on circumstances) between the nation that collects the tax (20 percent), a global development fund (50 percent), and international lender of last resort (30 percent).

With a likely annual dividend of about US\$ 150-300 billion, this could be a highly effective measure, and if intelligently used could be successful in moderating the technical efficiency of highly mobile financial capitals. No doubt there are considerable political and institutional difficulties in implementing and operationalizing the tax, and in this respect the proposal has to be seen as a mediumto-longer-term plan. But this fails to detract from the likely systemic needs of such a policy. ${ }^{10}$

\section{Davidson proposal for global financial institutions}

Paul Davidson has over many decades consistently proposed institutional changes to the global financial system that fundamentally reform the financial architecture. He regards the Tobin Tax as possibly a useful but ultimately a limited measure of reform. What is needed, he argues, is not simply a new tax to "fix the plumbing" but rather a useful institutional apparatus that promotes stability due to the coherent organization of its norms and rules. The core of his proposal is a threefold institutional system of preventing inadequate global demand, providing a mechanism of balancing surplus and deficit current account nations, and having a form of global currency.

Stability is best obtained, he argues, by ensuring that flows of funds do not cumulatively aggregate in certain nations at the expense of others. The best way to do this is supposedly to have a rule whereby the onus is on current account surplus nations to expand demand sufficiently to balance their international payments. In this way, they would enhance demand for deficit nations' goods and services and thereby lessen global imbalances. This would reduce the need for deficit nations to engage in excessive debt and thereby likely moderate financial instability. Davidson proposes to have an independent international reserve asset currency which is only held by reserve banks. This reserve asset has one-way convertibility with domestic currencies, and is used in exchange for international goods and services. There is also a fixed exchange rate between the reserve unit and domestic currency, that changes only "to reflect permanent 
increases in efficiency wages" (Davidson 2004:602). It is not helpful to have the current “de facto US dollar system" because US domestic monetary policy may not be in the best interests of global stability (see Schulmeister 2000). The international reserve asset can therefore be used specifically for global transactions and cannot be controlled for US monetary policy purposes.

In his system, surplus current account nations can spend "excess surpluses" on products of deficit member nations, new FDI projects for deficit nations, and unilateral transfers such as foreign aid for deficit nations. However, it cannot resolve the surplus by merely lending to deficit nations, which would not normally help them in the long run. If a surplus nation fails to spend the excess, it can be redistributed by the clearing agency to deficit nations for development (or similar) purposes. Drawing inspiration from J.M.Keynes, Davidson (2004:605) believes that "[g]lobal depression does not have to happen again if our policymakers have sufficient vision to develop this Post Keynesian approach.” Clearly, such a system of institutions is a long-term project, but nevertheless, probably a positive one for global growth and stability.

\section{Domestic asset-based reserve requirements}

One policy initiative that can simultaneously be used against hot capitals from overseas as well as domestic speculative bubbles is that of "asset-based reserve requirements" (ABRR) for monetary policy purposes. This is an initiative suggested in the light of the reduced importance of traditional bank deposits and the greater securitization, home equity lending, and stock market or equity holdings of the community. At present monetary policy in most nations concentrates on interest rate targeting, so that if real estate or equity markets require moderation the central bank can increase interest rates, but at the risk of not only negatively impacting on the required market(s), but also reducing investment and GDP. With ABRR, governments can specifically target these high growth and unstable markets without directly affecting broader aggregates.

For instance, if equity markets are generally expanding as well as showing signs of erratic behavior (typical of speculative bubbles) then the central bank may increase the reserves that financial institutions need to hold in an account with the reserve bank (based on their holdings of bubble assets). This can have the effect of reducing the demand for equities and thus moderating growth and instability in the market, without negatively affecting investment and GDP. A similar policy could be put into practice where bank loans from overseas (hot capitals) or home loans/commercial property development loans are showing signs of high growth and instability. As Thomas Palley says:

At the macroeconomic level, ABRRs can provide monetary authorities with multiple independent additional tools of monetary control that can supplement existing control over the short-term interest rate. In terms of Tinbergen's...targets and instruments approach to macroeconomic stabilization policy, ABRRs can provide additional instruments that allow policy makers to focus on additional economic targets [such as speculative bubble moderation]. This can be especially useful when fiscal policy is constrained by budgetary concerns.

$(2004: 46)^{11}$ 
Palley believes that the ABRRs are better than risk-based capital adequacy (RBCA) measures since ABRRs target assets rather than liabilities, and they have a positive impact during a slowdown, whereas RBCAs create the need for financial institutions to find additional capital during slowdowns when risk is often said to increase. ABRRs need to be applied to all financial institutions, they can be used selectively on specific assets, and have a potentially international scope in terms of usage. They also need to be revised from time to time as financial institutions try to evade their reach through institutional and technological change.

\section{Governance policies 4: terrorism and the war on terrorism}

Here we center on policy measures that directly link to each of the conflicting tendencies associated with terrorism and the so-called war on terrorism. Some general points need to be mentioned first, though. A coherent global strategy needs to be formulated that deals with all levels of the problem, from prevention to deterrence to defense. Included here is a whole stream of dimensions, including the upgrade of intelligence work, homeland security, global cooperation, missile defense, conventional forces, consequence management, and nonproliferation agreements. Especially important is the building of global cooperation through institutions and relationships. Also critical is prevention and deterrence, because once a terrorist attack has been activated it may be difficult to ascertain precisely the source of the attack. Future attacks may be even more obscure and difficult to pin down. And finally, it is not sufficient to devise strategies to minimize "political terrorism," since all dimensions of the problem from "political," to "war" and "state," to "cultural” terrorism are all critical to minimize in the global political economy. Quite often, as well, terrorism is inextricably linked to war and other forms of conflict, so this needs to be factored in as well.

\section{Policies on public awareness and consequent management}

First, the vast majority of people have little knowledge of the statistics of relative fatalities and the ways in which terrorists (as well as governments) use "big events" and the media to multiply and amplify their problems and concerns. The public needs to become more aware of these factors, while the media needs to be more responsible in not playing into the hands of terrorists in this fashion. Also, there needs to be a concerted effort to promote what William Perry (2002) calls “consequence management." This is the management of the human after effects of terrorist tragedies, including the strengthening of the operations of firefighters, police, national guard, reserve units, and the centers of disease control. It is critical to have sufficient reserves and an adequate system of activation against biological agents such as poisons and disease microbes. Sufficient stocks of antidotes, antiserums, antibiotics, and inoculations may reduce the degree of fear and intimidation.

\section{Policy measures on technology}

Second, in response to the "technology-terrorism" link, a potentially useful policy response can be "circuit breakers" to reduce the circular and cumulative technological 
and system network effects and relationships linked to terrorism. They intervene in the negative feedback effects of terrorism, or promote additional buffers as alternative sources of supply. It is necessary to reduce the number and importance of "critical nonredundant nodes" - or central information centers - so that there are alternative sources of knowledge and data storage. ${ }^{12}$ Decentralization of industry and the promotion of alternative sources of energy - as well as the creation of a alternative government "in hiding" (which is in motion in the United States) — can reduce the negative consequences of terrorism. Promoting local autonomy of food production can also help, in the case of national or transnational systems of supply being interrupted. Reducing the extent of justin-time production methods can have the same effect (Homer-Dixon 2002). Ensuring that there is a degree of decentralization of information through the Internet and institutional information systems is also important.

A national missile defense capability may provide an insurance policy against a sophisticated attack, although it does not help against the more likely attacks. An effective campaign against the proliferation of nuclear and biological weapons is necessary. Continuing the existing Nonproliferation Treaty, the Biological Weapons Convention, and the Strategic Arms Reduction Treaty (START), as well as activating treaties not yet formalized or implemented such as START II and III, those between the United States and North Korea, the Comprehensive Test Ban Treaty, and the Trilateral Agreement between the United States, Russia, and the Ukraine, will help (Perry 2002). Putting more resources into a more conventional defense system makes sense- such as the modernization of aircraft carriers, modern information technology, and specialist battle troops. (Although this may stimulate forms of state terrorism, which needs to be guarded against.)

There are many limits to the extent that "political" terrorists can effectively use chemical, biological, radiological, and nuclear means to generate weapons of mass destruction (WMD) (Hoffman 2001). Nevertheless, even if it were true that most sources of WMD are unlikely, there are plenty of other materials - chemicals, microorganisms, and nuclear energy - that could conceivably be effective, even if difficult to deliver on a mass scale. Examples include smallpox (formerly thought to be scarce), weapons-grade nuclear material (if not nuclear weapons), nerve gases such as sarin (used by Aum Shinrikyo in a Tokyo subway in 1995), and dozens of more freely available chemicals and toxins. The supply of microorganisms, nuclear material, nerve gas, and the like on the global black market poses grave problems of supply.

\section{Policy measures on regulation and security}

Third, a new balance between security and freedom will be necessary, where the key to success will be close global cooperation against terrorist networks, including state terrorism. New governance measures will be necessary to regulate the global transfer of money, particularly to increase the level of transparency. Export controls will be required to check merchandise and supply chains. Suitable measures are in place at many airports for travelers, but these will need to be incorporated into the flows of money and capital as well. Certain basic regulations will be required on the global Internet, cyberways, and computer systems. 
Terrorists are currently working on what is called Offensive Information Warfare, an example of which is netwar, a type of cyberterrorism, used either to sabotage or gain information globally, nationally, or regionally. However, there will be problems in applying these regulations; for instance, the difficulties in having a truly transatlantic (and beyond) system of governance in place (Bartsch 2001). Terrorists try and impair the trust that the public and corporations have developed in the use of the Internet and information technology. They are currently trying to corrupt strategic nodules in the system and infiltrate official networks to gain strategic information. Al-Qaida are known to be actively involved in cyberspace (Wheeler 2001), and many of their leading members have a considerable amount of technical knowledge and university training. The corruption of information technology nodules can potentially destroy the positive externalities associated with the Internet, due to the complex interdependencies involved. Sabotage of this type could disrupt whole global networks of business, causing a major recession or worse. It is thus critical to develop more alternative nodules, a reduction in the tightness of the information fit, and alternative sources and storage of data. As Valery and Knights recognize (2000), however, this will require a radical increase in the level of priority given to information and systems-security in companies and government departments. The evidence shows that company executives tend to be reactive rather than proactive to security breaches (Danphousse and Smith 1998), ${ }^{13}$ although in the last few years this has changed to some extent.

\section{Policy measures for global cooperation}

Fourth, a survey (March 2002) has shown that "the Islamic World” tends to view the United States as an aggressive and arrogant imperial force. For instance, 53 percent of respondents from nine Muslim nations have an "unfavorable" opinion of the United States. Seventy-seven percent believe that US military action in Afghanistan is "morally unjustified." And 61 percent did not believe that the September 11, attacks were undertaken by Arabs (Gallop Poll 2002). Clearly, the United States has a terrible image in these nations, especially in Pakistan, Saudi Arabia, Iran, Iraq, and Jordan. The support for radical Islam is growing, especially since the second Iraq War began, and a critical way to reduce actual and potential conflict with the area is by having better cultural, political, and economic linkages. In short, multilateralism needs to be deepened, expanded, and rooted in effective participation and dialogue with Islam that goes way beyond questions of “national interest.” As Jonathan Stevenson (2001-2002:44) says: “Constructive but cautious engagement with lesser evils-be they terrorist groups or their suspected state sponsors-is a price worth paying for the capacity to confront the greater evil without quarter." We need to thus go beyond not only neoliberal economic policies but also the neoconservative proponents of US imperial pursuits around the globe.

Islam has progressive elements in its thought, particularly well illustrated through the tenets of Islamic political economy. ${ }^{14}$ But a "spectre is haunting the world-the spectre of Muslim fundamentalism” (Hyman 1985:3) —and as a result a crisis has existed within traditional Islamic thought and practice for some time now. The relative decline of Sufi spiritualism, and Islamic secular nationalism, colonial domination, and the existence of certain demagogic notionally Islamic governments, left a spiritual vacuum that fundamentalism has sought to reconstruct along more activist lines. But there are 
alternatives to fundamentalism, and many scholars and officials have called for Islamic renewal —along traditional cultural lines — as a way of denting the impact of radical Islam and hence political terrorism. This is said to be in line with the tenets of Islam for a periodic renewal or revival of Islamic faith and the emergence of "fresh impulses."

Richard Bulliet (2002), for instance, believes that the foundations of this renewal are already in motion; for instance, in a revival of Sufi philosophy in Iran, Central Asia, and other areas; the advocacy of participatory governing institutions by people such as Hezbollah leader Sheik Muhammad Fadlallah; and a series of progressive Islamic institutions such as the Institute of Islamic and Arabic Sciences in the United States. Murad Hofman (2001) puts forward a program of renewal, which has similarities with other programs, based on (a) the division of power, (b) female empowerment, and (c) general emancipation. Hofman suggests to counter the influence of radical Islam and political terrorism through the promotion in Muslim nations of public participation, individual rights, female inclusion, transparency of institutions, reduced inequality, innovation and increases in both productivity and literacy.

He links these notions to Islamic tenets and philosophies, particularly stressing the need to eschew "Muslims [trying to] catch up with the Joneses in a consumerist spirit...since Muslim life should never be dominated by economic considerations" (p. 303). Nevertheless, issues of livelihood, power, and governance are critical to Islam. The advocacy of such principles and programs are needed in tandem with religious authorities "able to declare that the killing of innocents by terrorist attacks is contrary to Islam and...Muslims can stand firmly against terrorism without seeming to embrace the United States and its policies" (p. 16). Sherman Jackson (2001:293) demonstrates philosophically the ways in which terrorism may be in contradistinction to Islam. ${ }^{15}$ As a policy issue, the renewal of Islam in this fashion is critical to the fight against the killing of innocent civilians.

\section{Governance policies 5: trust, equality, and stability}

During the 1970s-2000s, neoliberalism resulted in an expansion of greed, selfishness, and private motives over social sentiments such as trust, equality, and stability. This imbalance had a major impact on the social fabric as well as economic performance. Trust has recently come to the fore in the form of the concept of social capital, which has been shown to stimulate a positive business environment. Without sufficient trust no system of business is possible since transaction costs would be raised to a high level and legal actions would lead to high administrative expenses. It also leads to lower quality of life for most as people's livelihood depends upon being able to trust people to do what they say they will, and that they can be depended upon in times of need (see Nooteboom 2002). This decline in trust and rise in individualism is a classic contradiction and leads to major socioeconomic instability and crisis.

The last 20 or 30 years has also seen a rise in global inequality, and a decline in the ability of people with certain capabilities to put them into practice because of a lack of financial and other resources. The class divide has become stronger as those with modern skills, high-technology expertise, and administrative experience have increasingly been divided from those who are unable to benefit substantially from the innovations of a modern society. Globally the nations of the center and rapidly developing nations of Asia 
and elsewhere have drawn apart from those of Africa, the Middle East, and parts of South Asia and Latin America. All this puts great strain on the global processes of interaction and development.

The process of individuation has spread over the past 2 or 3 decades as individuals have sought to "be all that they can," and achieve as much as possible. Compassion, sentiment, and sociality have declined, partly as a result of governments encouraging greed, personal reward, and financial remuneration. The social dislocation has also grown through the expansion of the pecuniary, emulative, and exploitation propensities. The philosophy behind this is that an expansion of individual concerns leads to better economic performance. However, this ignores the role that trust, concern for others, and community can play in providing public goods such as cooperation, peace, agreement, and accord. Some sort of dynamic balance is required between greed and concern for others to prevent socioeconomic problems from deepening, such as the expansion of transaction costs, crime, and anomie.

Competition needs to be tempered by corporate cooperation, in the form of strategic alliances, joint ventures, and corporate internalization. Too much competition leads to lower profits and hence problematic investment and growth. Greater competition between people also creates social instability as families decline, the democratic way of life deteriorates, and community association suffers. In short, we have seen economic dominance over society and hence the reemergence of the disembedded economy.

Introducing governance issues into the milieu of economy dominating society poses difficulties because it is a cultural and hence a long-term problem. Culture changes at differential rates depending on the environment and potential for change. To some degree there is no turning back, and neoliberalism and globalization must suffer from its own inability to create sociality through the "free" market approach. Out of the turmoil of failure new structures emerge, and people opt for different solutions to their problems. Governments can intervene into the process to some degree, but going against the grain is a difficult process. Many of the principles and proposals examined below are of a longerterm duration than is usually linked to long wave upswing; 20 or 30 years may be required in some cases for the required momentum to be generated at the cultural level (if at all it does occur).

\section{Governance programs for generating social capital}

Institutions of trust, equality, and stability relate to questions of strong reciprocity, participation, and sociality. The expanding literature on social capital shows that trust, reciprocity, and participation can emerge within and between markets, within and between governments, and within and between communities. It is not necessarily a third area of governance in addition to markets and governments. Indeed, trust, reciprocity, and participation may enhance all institutions to some degree if it is embedded within and between them.

Much of what is called social capital is really sectional or relative social capital, in the sense that it advances the interests of a group or series of groups (or institutions) at the absolute or relative expense of others. Not all social capital is the type discussed by Robert Putman (2000), which is communal in nature and generally benefiting everyone, 
although this macro, national, or global social capital is probably the most important of all.

First, there is prosocial capital and antisocial capital. Antisocial capital is that which has historically promoted negative externalities, such as the activities of the Ku Klux Klan, the Mafia, urban gangs, militia movements, drug cartels, and crime syndicates (Streeton 2002:44). Prosocial capital, on the other hand, is the building of relations of reciprocity and networks than enhance community participation and sociality, such as local health centers, book clubs, musical societies, the Red Cross, and the Salvation Army. Governance systems should encourage prosocial organizations, although it is not always easy to ascertain what is prosocial and antisocial, since this may be clouded by social norms, popular culture, and political ideology.

Second, policy measures need to take into account that what might appear to be prosocial capital may actually be a form of rent-seeking institution. Some groups specialize in promoting linkages between members of a group for the benefit of the wider community, while others specialize in promoting linkages and benefits for members only. Both of these are likely to be either positive or benign in nature. However, other networks of people-which normally would not be viewed as antisocial-specialize in how to obtain resources from the wider community without benefiting society in general. These may include businesses, lobby interest groups and single issue groups.

A third problem is the importance of power differentials and group distinctions in the social capital equation (White 2002). As Pierre Bourdieu (1997) recognizes perhaps better than anyone, the acquisition of social capital is one means whereby certain classes are able to advance their relative income, wealth, and sociality-even if prosocial capital is apparently being generated in the process. In other words, much of social capital is less social than group or class in nature, since "Power relations are rooted in the system of social networks” (Foucault 1982:224). Typically this is undertaken through, for instance, entrepreneurial networks; networks of families, friends, and associates involved in business; and business networks in employer groups. Class distinctions are reinforced through such networks and relations of reciprocity that are a normal and even an established part of civil society.

One set of policies that take these problems into account is the recent Irish "New Public Policy Agenda” to include social capital in governance (NESF 2003). First, it seeks to foster prosocial capital through government activities. This program seeks to build community capital through, initially, a formal social capital audit and the development of performance indicators. This program includes consultation of local communities in government decision-making processes, making impact assessments of policies on community networks and family-friendly practices, analyzing connections between different ethnic or social groups, a balance between community participation and government intervention, accountability, and the provision of infrastructure for local services.

This Irish policy agenda also recognizes the class and group nature of much social capital. As the NESF report says:

The ability to participate more fully in society and decision-making is not equitably distributed: some groups and individuals with important human, social and economic resources have greater access to decision-making and 
social advantage. Hence, the focus of much community development in Ireland is in advancing the development of groups who are disadvantaged or excluded.

As a result, the program seeks to promote networks and relations of reciprocity for the unemployed, those with few social and workplace skills, homeworkers, those with ailments, ethnic minorities, and areas that are disadvantaged. This problem of relative social capital and the group acquisition of social privilege and power is a critical theme to incorporate in the agenda of governance for the future. ${ }^{16}$

\section{Worker cooperatives and economic democracy}

In a longer-term vision, trust and sociality may be promoted through a whole array of institutional innovations associated with what Samuel Bowles and Herbert Gintis (2002) call "community governance." A critical one is the development of proper legislation and tax incentives to encourage the expansion of worker cooperatives. There are many examples of successful cooperatives, such as the Mondragon Experiment in Spain, the Semmler systems of worker empowerment in Brazil, the Toyama Bay fishing cooperatives in Japan, and the plywood workers cooperatives in Oregon and Washington, to mention just a few of the more well known.

Worker cooperatives can help to restore community governance through increases in productivity which typically flow from tapping the creative energies of workers, increasing their incentive to work and innovate, and reducing the costs of supervision. Cooperatives also tend to be embedded in local or regional structures of association, and thereby encourage reciprocity and networking, expanding the regional income multipliers, and creating a sense of community and corporate pride and democracy. A critical need in the current environment is not only to promote participation in politics, but more especially to make the economy more democratic and participatory. ${ }^{17}$

Revisions to business law, for instance, could encourage cooperatives by making it easier for workers to band together in this way, and also for cases when ordinary firms change to cooperatives. A slightly lower rate of corporate taxation could encourage this form of business organization. The organizational provision of micro-finance specifically for cooperatives would help when workers lack start-up capital. Encouraging labor to employ capital requires institutional encouragement since it goes against the grain of many corporate structures and dynamics.

\section{Political capital and the rule of law}

A critical problem in many areas is the tendency for relations of reciprocity and networks to emerge within families, friends, and relations. In places such as much of Latin America, Chinese parts of Asia, much of the former Eastern block and parts of southern Italy where civil society was unable to develop sufficiently, trust and sociality is mostly confined to small groups. Out of these groups emerged family businesses, close-knit networks and a distrust of non-kinship relations. This "two tiered moral system" of insiders and outsiders, as Francis Fukuyama (2002) calls it, often manifests in nepotism, 
corruption, and "conflicts and hostilities when viewed as a whole" (p. 30). In this environment, often government officials simply prefer to look after family and kinship relations before the wider concerns of society and nation.

In this type of environment, it is usually highly desirable to adopt a policy program of "strengthening the rule of law and the basic political institutions on which it rests" (p. 32), or what many have called "political capital." When there is a lack of trust in society, when people often do not trust strangers, an alternative source of stability is a more fully embedded system of legality, judiciary, and courts. The setting up of business law, including the torts and contracts, is a critical aspect of strengthening macro relations and associations. Also important is the protection of human rights and the freedom of the press, association, and assembly. A well-developed police force that is seen to protect the population from crime gangs and "business outlaws" can help to protect and develop the community. This may enable the development of a wider set of social norms and mores through certain habits, institutions, and leadership. In time the insular nature of social capital may lead to less fragmentation and dislocation of wider social bonds. ${ }^{18}$

But the problem of lack of civil society is not restricted to developing and transitional economies. Robert Putman, for instance, persuasively puts the case that civil society has been deteriorating in the United States for a number of decades now. Familial and community capital have both been in decline as people spend more time in activities relating to work, travel to far away places, divorce from local issues, and concentrate on the concerns of the individual more than community. One of his chief concerns, for instance, is the lack of participation of people in debates and activities relating to politics. In response to this, he suggests five main policies (Putman 2000: ch. 24). These include improved civics education in schools as a core part of the curriculum, greater flexibility in work schedules so that people can engage in more family and community activities, reorganizing urban and regional planning, including public space, so that there are more opportunities for casual socializing with friends and neighbors, a realignment of communications toward civic projects such as "civic journalism" to foster community engagement, and a greater degree of decentralization of government authority to encourage participation of the public in areas that affect their lives. ${ }^{19}$

\section{Conclusion}

This study has sought to critically analyze the dominant institutions of global capitalism on the basis of their operational contradictions. These contradictory processes link positive and negative forces together since they are inextricably related. The positive or at least forward-looking forces are the potentially revolutionary power of foreign direct investment, communications and biotechnology innovation, financial institutions, transnational integration, and mobile capital. The negative forces are the tendency toward insufficient effective demand, excess competition, uneven growth and development, speculative bubbles, socioeconomic instability, and global conflict. The positive and negative forces emanate from the conflict between finance and industry, capital and labor, competition and cooperation, center and periphery, as well as production and reproduction. The manifestations of these contradictions include low global profitability, productivity, economic growth, and development. 
The question then arises as to whether these positive and negative forces are so interlocked as to preclude the use of governance measures to improve socioeconomic performance. Are we left to the evolutionary forces of capitalism for any changes that affect substantive economic outcomes? Can governments, corporations, and civil society intervene to moderate the negatives without also lowering the positives? To some degree the negatives can only be moderated through a decline in the positives. But they are not so strongly interlocked as to preclude conscious efforts at improving performance; the real question is the degree to which this is possible. The case outlined in this chapter is a reform agenda based on post neoliberal governance.

The PNG is specifically designed to moderate the conflicts and instabilities of the institutions, although I do recognize that the evolutionary forces at play may in many respects be more important to the outcomes that emerge. Governance policies concentrating on specific global anomalies were analyzed in this chapter. In brief they include:

- Reducing the degree of center-periphery uneven development through rectifying the terms of trade anomalies, reducing corruption and instituting industry policy, and deepening the role of a global development fund.

- Lessening the degree of crowding out of private investment by FDI in some nations through measures designed to screen capital inflow in order to promote greenfield investment.

- Enhancing productive government spending in the areas of education, infrastructure, health, and communications while moderating the relatively unproductive areas of the military and transfer payments.

- Moderating the conflict between industry and finance through some combination of Tobin Taxes, Davidson's proposal, ABRR, and changes in corporate governance.

- Reducing the conflict between the United States and its allies and terrorist networks through specific regulations, public educational programs, moderating US aggression in the Middle East, and promoting Arab development and progressive Islamic trends.

- Designing longer-term community governance processes to promote trust, equality, and social stability even if the evolutionary forces of capitalism tend to inhibit this through enhanced individualism and greater inequality of income and wealth.

Post neoliberal governance is a more progressive agenda than neoliberalism in trying to embed society in economy through more productive and reproductive institutions. It seeks to promote more stability, conflict resolution, and performance by concentrating on sustainable long-term practices and dynamics. It seeks to ensure the smooth flow of the circuit of social capital through historical time and space. This requires the promotion of more trust and community, productive government activities, a healthy dominance of industry over finance, a substitution of communitarian liberalism for neoliberalism and neoconservatism, and the promotion of industry policy and high-value-added activities. Only then will the global political economy undergo sustainable growth and development into the future.

\section{As Ben Fine says:}


Stiglitz himself has released a volley of papers addressing everything from the East Asian crisis to the failed transition in eastern Europe. They do...share crucial features. First, they are increasingly informal in content, departing from the formal techniques and mathematical modelling with which Stiglitz established his reputation. Second, they are increasingly accommodating to the old consensus even if market imperfections continue to be set against neo-liberalism. Third, they increasingly involve what can only be described as lofly assessments with limited regard for detailed research and acknowledgement of the full range of existing literature. Fourth, the conclusions frequently border on the vacuous, since they reduce to specific application of the notion that account has to be taken of market imperfections - as in the conclusion, for example, that preconditions for market governance better be in place before proceeding with privatisation.... In order to retain notions of class, power, conflict, and development as a contradictory process involving major social and economic transformation, the information-theoretic approach must not be allowed to succeed in its colonising mission.

2 A set of policies that are in many respects comparable (in political economy emphasis) with the themes and governance strategies presented here, is that developed by George Demartino (1999). However, Demartino does not set out to develop policies appropriate for long wave upswing, and therefore his analysis is perhaps more long-term than that developed here. Although it has to be said that some of the policies developed in this present chapter are fairly long-term, since long wave upswing may take quite a while.

3 For instance, Angelo Reati and Jan Toporowski (2004) develop a detailed policy framework specially designed for the European context. This includes a long wave perspective concentrating on (a) a Keynesian demand scheme, (b) promoting productive rather than simply finance capital, (c) the employment relationship, (d) a targeted flexibility of labor, and (e) a new regime for intellectual property rights. Ha-Joon Chang and Ilene Grabel (2004) concentrate on alternative policies for developing nations, paying particular attention to trade and industry, privatization and intellectual property rights, international private capital flows, domestic financial regulation, and macroeconomic policies and institutions.

4 For instance, Aschauer (1989) argues that the decline in government capital expenditure in the United States over recent decades is responsible for a large part of the long-term unemployed. Aschauer (2000) further investigates the effects of different means of financing government spending on economic growth. With respect to the influence of economic growth, a higher rate of public investment financed by money creation is shown to have a greater influence on economic growth than a higher rate of public investment financed by an increase in taxes. Capital expenditure is best financed via money creation, which has decisive influence on growth and employment.

5 As Abba Lerner himself said:

The central idea [of functional finance] is that government fiscal policy, its spending and taxing, its borrowing and repayment of loans, its issue of new money, and its withdrawal of money, shall all be undertaken with an eye only to the results of these actions on the economy and not to any established traditional doctrine about what is sound or unsound 
6 For Wray, unemployment is a result of an imbalance between actual savings and desired savings. If desired savings exceed actual savings then aggregate demand will be lower than that which achieves full employment. Desired savings will not equal actual savings when the government has kept the supply of fiat money too low (Wray 1998:84). By increasing government spending, the government can equalize desired and actual savings, thereby achieving full employment. On the other hand, if actual savings are smaller than desired savings, then aggregate demand is in excess of that required for full employment, potentially causing inflation. The government can sell bonds or increase taxes to inhibit the supply of funds in the market. This should lower inflation to the point that desired savings is once again equal to actual savings. Hence, budget surpluses may be required from time to time, although only temporarily.

7 As Stiglitz says:

Incomplete information, incomplete markets, incomplete contracts are all inevitable features of the economy in general and the financial system in particular. In this circumstance the market outcome is not even constrained Pareto efficient; even a government faced with the same informational constraints as the market would be able to make Pareto improvements-a theorem Bruce Greenwald and I proved a decade ago. The finance system is focused on information problems. That is why it is so important that the government must play an essential role in the regulation of the financial system. For most countries, doing this correctly will entail a sustained regulatory reform over a number of years. In no country does overnight deregulation make sense. In the banking system, effective intermediation requires banking regulations to create incentives for bank owners, markets, and supervisors to all use their information efficiently.

8 Certainly this is the impression one gets from reading the fortnightly published IMFSurvey [sic]. For instance, the following quote from the Argentine experience perhaps situates the current IMF position well:

The crisis [in Argentina] resulted from the failure of Argentine policymakers to take necessary corrective measures sufficiently early. IMF surveillance failed to highlight the growing vulnerabilities in the authorities' choice of policies and the IMF erred by supporting inadequate policies for too long. By 2000, there were concerns about exchange rate and debt sustainability, but recognising the large costs of exit, the IMF supported Argentina's efforts to preserve the exchange rate regime.... However, subsequent dispursements made despite repeated policy inadequacies only postponed the fundamental resolution of the crisis.

(IMF 2004:230)

9 Some very helpful papers have emerged on the recent corporate crises associated with Enron, WorldCom, and so on. Perhaps the most insightful and critical is the one by Scott Klinger and Holly Sklar (2002) who present the problems as institutionized habits of corporate America. They show how the problems of abuses of power and authority are incorporated 
into the fabric of American political economy, which cannot be easily erased by simple government policy and legality. So while the recent legislation may have some impact around the edges, little is likely to change in the wider perspective, either for short-term finance versus industry purposes or for longer-term issues.

10 James Tobin (1978) proposed a 1 percent tax on global hot financial capitals, while Howard Watchel (2000) suggested a tax rate in the order of between 0.1 and 0.25 percent due to the fairly low margins of many financial transactions (of around 1 percent). Watchel concludes that the Tobin Tax satisfied quite well the technical requirements of sucy taxes: for instance, that they be simple, easy to administer, linked to sound and sensible policy, and raise sufficient revenue to negate potential political backlash from politicians in need of taxation to counter the recent decline in their corporate tax base.

11 Palley presents a model to explain the operations of ABRR and how it compares to the current system of liability-based reserve requirements. The current system in most relevant nations is imposed on bank deposits and they tend to be stable through time. He argues that ABRRs, on the other hand, change the relative price of holding various types of assets and have an allocative impact similar to selective credit controls.

12 Thomas Homer-Dixon, for instance, believes that

the World Trade Center was not a critical, nonredundant node. At least it wasn't critical in the way most people (including, probably, the terrorists) would have thought. Many of the financial firms in the destroyed buildings had made contingency plans for disaster by setting up alternate facilities for data, information, and computer equipment in remote locations.... NASDAQ officials [for instance] later claimed that their system was so robust that they could have restarted trading only a few hours after the attack.

13 Valery and Knights (2000) believe that Islamic extremists are unlikely to try and sabotage the Internet or other information nodules because of their "established operational style" (p. 21). However, the September 11 attacks have taught us that they are quite likely and capable of taking risks and making innovatory changes in their strategies. This is also the message of the analysis done by Moorhead Kennedy (1998) and also Kelly Damphousse and Brent Smith (1998).

14 For instance, IPE places emphasis on the Oneness of God linked to the stock of universal knowledge that augments cognition through institutions and social systems (Choudhury and Salleh 2001:586-587).

15 Sherman Jackson (2001) shows how, in classic Islamic law, the promotion of hirababparticularly if murder propels fear and intimidation (whether wittingly or not) among the population-is subject to major penalties.

16 The policies adopted in Kerala, India, to develop community capital and association, are especially germane here. The state of Kerala has one of the lowest income per capita levels in India but the highest standard of living in the country. A number of scholars, such as Patrick Heller (1996) have put this down to the leftist government promoting social capital through community. As he says: "Kerala's caste self-help and social upliftment societies have a long history of active civil engagement. Its 'library movement', literary associations and film industry ha[ve] earned it a reputation as a cultural center rivalled only by Bengal” (p. 1055). He concludes that "what is certain is that the synergy between working-class mobilization and state capacity has directly contributed to building the political and institutional foundations most likely to effectively 'manage' the contradictions of democratic capitalist development” (Heller 1996:1067). 
17 Of course, some worker cooperatives would seek only to promote internal objectives to enhance the material welfare of the firm. But the type of policies we are exploring here seek to promote a more community-minded sort of cooperative. Along these lines, Bowles and Gintis (2002: F429-F431) suggest some rules of thumb to promote community governance. These rules include (1) "members of the community should own the fruits of their success or failure in solving the collective problems they face"; (2) "the unravelling of co-operation that often afflicts communities can be averted if opportunities for mutual monitoring and punishment for non-co-operators are built into the structure of social interactions"; (3) "wellworking communities require a legal and governmental environment favourable to their functioning"; and (4) "active advocacy of the conventional liberal ethics of equal treatment and enforcement of conventional anti-discrimination policies.” These rules should, however, be seen within the context of the promoting of many positive externalities, so that many things are not internalized into the monetary or property reward system.

18 It needs to be emphasized, though, that the promotion of property rights has been exaggerated as a critical means of governance, especially in relation to the development of trust, strong reciprocity, and participation. For instance, as Bowles and Gintis (2002: F431) note: "where property rights are ill-defined and informal contractual enforcement is essential to mutually beneficial exchange, more precisely defined property rights may reduce the multifaceted and repeated nature of interpersonal contact on which community governance is based."

19 Some evidence for developing nations suggests that trusting elected representatives is very important. For instance, in Uganda it was concluded that "the only variable that bears a clear relationship to generalised trust is the perception that elected representatives care about the concerns of ordinary people” (Widner and Mundt 1998). This indicates the critical importance for the development of political capital. Political capital may be defined as the development of a participatory political culture concerning the making of rules and institutions for community governance. However, it is true that "efforts to perfect the market or assure the success of state interventions have destroyed imperfect but nonetheless valuable community-based systems of governance, suggesting that policy paradigms confined to states and markets may be counterproductive” (Bowles and Gintis 2002: F429).

\section{References}

Ahmed, Habib and S.M.Miller. (2000) "Crowding-Out and Crowding-In Effects of the Composition of Government Expenditure,” Contemporary Economic Policy, Volume 18, Number 1, pp. 124-133.

Aschauer, D.A. (1989) “Does Public Capital Crowd Out Private Capital?” Journal of Monetary Economics, Volume 24, September, pp. 171-188.

Aschauer, D.A. (2000) "Public Capital and Economic Growth: Issues of Quantity, Finance and Efficiency,” Economic Development and Cultural Change, pp. 391-406.

Bartsch, Sabastian. (2001) “Capitalizing Terrorism” Internationale Politik: Transatlantic Edition, Volume 2, Number 4, pp. 13-18.

Bell, Stephanie. (2000) “Do Taxes and Bonds Finance Government Spending?,” Journal of Economic Issues, Volume 34, Number 3, September, pp. 603-620.

Binswanger, Mathias. (2000) "Stock Returns and Real Activity: Is There Still a Connection?" Applied Financial Economics, Volume 10, August, pp. 379-388.

Bourdieu, Pierre. (1997) “The Three Forms of Capital,” in A.H.Halsey, High Lauder, Phillip Brown, and Amy Stuart Wells (eds), Education: Culture, Economy and Society, Oxford: Oxford University Press, pp. 46-58. 
Bowles, Samuel and Herbert Gintis. (2002) "Social Capital and Community Governance,” Economic Journal, Volume 112, pp. F419-F436.

Bulliet, Richard W. (2002) “The Crisis Within Islam,” The Wilson Quarterly, Volume 26, Number 1, pp. 11-19.

Bush, Paul Dale. (2001) “Institutional Change and Adjustment,” in Phillip Anthony O’Hara (ed.), Encyclopedia of Political Economy, London and New York: Routledge, Volume 1, Paper edition, pp. 521-523.

Chang, Ha-Joon and Ilene Grabel. (2004) Reclaiming Development: An Alternative Economic Policy Manual, London and New York: Zed Books.

Choudhury, M.A. and Muhammad Syruki Salleh. (2001) “Islamic Political Economy,” in Phillip Anthony O’Hara (ed.), Encyclopedia of Political Economy, London and New York: Routledge, pp. 585-586.

Cuddington, John T., Rodney Ludema, and Shamila A.Jayasuriya. (2002) Prebisch-Singer Redux, Working Paper of the Economics Department, Georgetown University, January.

Damphousse, Kelly R. and Brent L.Smith. (1998) "The Internet: A Terrorist Medium for the 21st Century,” in Harvey W.Kushner (ed.), The Future of Terrorism: Violence in the New Millennium, London and New Delhi: Sage Publications, pp. 208-224.

Davidson, Paul. (2004) “The Future of the International Financial System” Journal of Post Keynesian Economics, Volume 26, Number 4, Summer, pp. 591-606.

Demartino, George. (1999) Global Economy, Global Justice: Theoretical Objections and Policy Alternatives to Neoliberalism, London and New York: Routledge.

Elsner, Wolfram. (2003) “Global Industrial Policies,” in Marc R.Tool and Paul Dale Bush (eds), Institutional Analysis and Economic Policy, Boston, MA and London: Kluwer Academic Publishers.

Fine, Ben. (2000) Neither the Washington Nor the Post-Washington Consensus: An Introduction, Working Paper of the Centre for African and Oriental Studies, University of London.

Fine, Ben, Costas Lapavitsas, and Jonathan Pincus. (2003) Development Policy in the Twenty First Century: Beyond the Post-Washington Consensus, London and New York: Routledge.

Foucault, Michel. (1982) “Afterword: The Subject and Power,” in H.Dreyfus and P.Rabinow (eds), Michel Foucault: Beyond Structuralism and Hermeneutics, Chicago, IL: University of Chicago Press, pp. 208-212.

Fukuyama, Francis. (2002) “Social Capital and Development: The Coming Agenda,” SAIS Review, Volume 22, Number 1, Winter-Spring, pp. 23-37.

Gallop Poll. (2002) "Survey of Middle Eastern People in the Arabian Gulf on Attitudes to the United States and the War on Terrorism,” Gallop Poll. February 2002, 66pp.

Gore, Charles. (2000) "The Rise and Fall of the Washington Consensus as a Paradigm for Developing Countries,” World Development, Volume 28, Number 5, pp. 789-804.

Heller, Patrick. (1996) “Social Capital as a Product of Class Mobilization and State Intervention: Industrial Workers in Kerala, India,” World Development, Volume 24, Number 6, pp. 10551071.

Hofman, Murad Wilfried. (2001) “A Plea for Islamic Renewal,” Islamic Studies, Volume 40, Number 2, pp. 297-304.

Homer-Dixon, Thomas. (2002) “The Rise of Complex Terrorism,” Foreign Policy, January/February, pp. 52-77.

Hyman, Anthony. (1985) “Muslim Fundamentalism,” Conflict Studies, Volume 174, pp. 3-27. Reprinted in Yonah Alexander (ed.), Middle East Terrorism: Current Threats and Future Prospects, New York and Toronto: Macmillan Publishing Company, 1997.

Ibrahim, Mansor H. (2001) "The Effects of Government Spending on Private Capital Formation: The Case of Malaysia," International Economics, Volume LIV, Number 1, pp. 187-201.

IMF (International Monetary Fund). (2004) "Key IEO Findings and Recommendations," IMFSurvey, Volume 33, Number 15, pp. 230-231. 
Jackson, Sherman. (2001) “Domestic Terrorism in the Islamic Legal Tradition,” The Muslim World, Volume 91, Numbers 3 and 4, pp. 293-310.

Kennedy, Moorehead. (1998) “The 21st Century Conditions Likely to Inspire Terrorism,” in Harvey W.Kushner (ed.), The Future of Terrorism: Violence in the New Millenium, London and New Delhi: Sage Publications, pp. 185-207.

Klinger, Scott and Holly Sklar. (2002) Titans of the Enron Economy: The Ten Habits of Highly Defective Corporations, Boston, MA: United for a Fair Economy.

Kolodko, Gregorz. (1998) “Transition,” World Bank Development Economic Research Group Newsletter, Washington, DC: World Bank, June.

Laopodis, Nikiforos T. (2001) "Effects of Government Spending on Private Investment," Applied Economics, Volume 33, pp. 1563-1577.

Lerner, A.P. (1943) “Functional Finance and the Federal Debt,” Social Research, Volume 10, pp. 38-51.

Lutz, Matthias G. (1999) “Policy Arena: Commodity Terms of trade and Individual Countries’ Net Barter Terms of Trade: Is There an Empirical Relationship,” Journal of International Development, Volume 11, pp. 859-870.

Miller, Nigel James and Christopher Tsoukis. (2001) “On the Optimality of Public Capital for Long-Run Economic Growth: Evidence from Panel Data,” Applied Economics, Volume 33, pp. 1117-1129.

Munzig, Peter Grosvenor. (2003) Enron and the Economics of Corporate Governance, Mineo, Department of Economics, Stanford University, June.

NESF (National Economic Social Forum). (2003) The Policy Implications of Social Capital, Forum Report No. 28. Dublin: Government Publications.

Nooteboom, Bart. (2002) Trust: Forms, Foundations, Functions, Failures and Figures, Cheltenham, UK and Northampton, MA: Edward Elgar.

Ocampo, Jose Antonio, and Maria Angela Parra. (2004) The Commodity Terms of Trade and their Strategic Implications for Development, Working Paper of the Economic Commission for Latin America and the Caribbean (ECLA), June.

O’Hara, Phillip Anthony. (2000) “A New Neoliberal 'Balanced Budget' Social Structure of Accumulation for the United States?,” in H.Bougrine (ed.), The Economics of Public Spending: Debts, Deficits and Economic Performance, Cheltenham, UK: Edward Elgar.

O’Hara, Phillip Anthony. (2005) A New Chinese Social Structure of Accumulation for Long Wave Upswing? Working Paper, Curtin University, GPERU, School of Economics and Finance, March, http://pohara.homestead.comygperu.html/

Palley, Thomas I. (2004) “Asset-Based Reserve Requirements: Reasserting Domestic Monetary Control in an Era of Financial Innovation and Instability,” Review of Political Economy, Volume 16, Number 1, pp. 43-58.

Patomaki, Heikki. (2001) Democratising Globalisation: The Leverage of the Tobin Tax, London and New York: Zed Press.

Perry, William J. (2002) “Preparing for the Next Attack,” Foreign Affairs, Volume 80, Number 6, pp. 31-45.

Putman, Robert D. (2000) Bowling Alone: The Collapse and Revival of American Community, New York: Touchstone Books.

Reati, Angelo and Jan Toporowski. (2004) “An Economic Policy for the Fifth Long Wave,” Banca Nazionale del Lavoro Quarterly Review, Number 231, pp. 321-359.

Robbins, Fred. (2002) “Industry Policy in East Asia,” Asian Business and Management, Volume 1, pp. 291-312.

Salvatore, Dominick. (2004) International Economics, Eighth Edition. Hoboken, NJ: John Wiley \& Sons.

Sapsford, David and V.N.Balasubramanyam. (1999) "Policy Arena: Trend and Volatility in the Net Barter Terms of Trade, 1900-92: New Results from the Application of a (not so) New Method," Journal of International Development, Volume 11, pp. 851-857. 
Sapsford, David and V.N.Balasubramanyam. (2003) "Globalization and the Glass Ceiling Hypothesis," in Harry Bloch (ed.), Growth and Development in the Global Economy, Northampton, MA and Aldershot, UK: Edward Elgar Publishing, pp. 157-169.

Schulmeister, Stephan. (2000) "Globalization without Global Money: The Double Role of the Dollar as National Currency and World Currency,” Journal of Post Keynesian Economics, Volume 22, Number 3, Spring, pp. 365-395.

Schweickert, Rainer and Rainer Thiele. (2004) From Washington to Post-Washington? Consensus Policies and Divergent Developments in Latin America and Asia, Kiel Discussion Papers, Kiel Institute for World Economics, February, 35pp.

Spotton Visano, Brenda. (2004) "Financial Crises, Crashes and Speculative Bubbles," in Phillip Anthony O'Hara (ed.), Global Political Economy and the Wealth of Nations: Performance, Institutions, Problems and Policies, London and New York: Routledge, pp. 225-224.

Stevenson, Jonathan. (2001-2002) “Pragmatic Counter-Terrorism,” Survical: The IISS Quarterly, Volume 43, Number 4, pp. 35-48.

Stiglitz, Joseph. (1998) More Instruments and Broader Goals: Moving Toward the Post Washington Consensus, the 1998 WIDER Annual Lecture, January 7, Helsinki.

Stiglitz, Joseph. (2002a) “Employment, Social Justice and Societal Weil-Being,” International Labour Review, Volume 141, Numbers 1-2, pp. 9-29.

Stiglitz, Joseph. (2002b) Development Policies in a World of Globalization, Paper presented at a seminar to celebrate the fiftieth anniversary of the Brazilian Economic and Social Development Bank (BNDES), Rio de Janeiro, September 12-13.

Streeton, Paul. (2002) "Reflections on Social and Antisocial Capital," in Jonathan Isham, Thomas Kelly, and Sunder Remaswamy (eds), Social Capital and Economic Development: Weil-Being in Developing Countries, Cheltenham, UK and Northampton, MA: Edard Elgar, pp. 40-57.

Tobin, James. (1974) The New Economics One Decade Older: The Eliot Janeway Lectures in Honour of Joseph Schumpeter, Princeton, NJ: Princeton University Press.

Tobin, James. (1978) “A Proposal for Monetary Reform,” Eastern Economic Journal, Volume 4, Numbers 3-4, pp. 153-159.

Valery, Lorenzo and Michael Knights. (2000) “Affecting Trust: Terrorism, Internet and Offensive Information Warfare,” Terrorism and Political Violence, Volume 12, Number 1, pp. 15-36.

Veblen, Thorstein Bunde. (1919) The Vested Interests and the Common Man ("The Modern Point of View and the New Order”), New York: Augustus M. Kelley, 1964.

Veblen, Thorstein Bunde. (1921) The Engineers and the Price System, Brunswick, NT and London, UK: Transnational Publishers, 1990.

Watchel, Howard M. (2000) “Tobin and other Global Taxes,” Review of International Political Economy, Volume 7, Number 2, pp. 335-352.

Weber, Christian E. (2000) "Government Purchases, Government Transfers, and the Post1970 Slowdown in U.S. Economic Growth,” Contemporary Economic Policy, Volume 18, Number 1, pp. 107-123.

Wheeler, Deborah W. (2001) "Beyond Global Culture: Islam, Economic Development, and the Challenges of Cyberspace,” Domes: Digest of Middle Eastern Studies, Volume 10, Number 1, pp. 1-26.

White, Leroy. (2002) "Connection Matters: Exploring the Implications of Social Capital and Social Networks for Social Policy,” Systems Research and Behavioral Science, Volume 19, Number 3, May-June, pp. 255-269.

Widner, Jennifer and Alexander Mundt. (1998) "Researching Social Capital in Africa," Africa, Volume 68, Number 1, pp. 1-24.

Williamson, John. (2000) "What Should the World Bank Think about the Washington

Consensus?,” World Bank Research Observer, Volume 15, Number 2, August, pp. 251-264.

Wray, Randall L. (1998) Understanding Modern Money: The Key to Full Employment and Price Stability, Aldershot, UK: Edward Elgar. 


\section{Further reading}

Dicken, Peter. (2003) Global Shift: Reshaping the Global Economic Map in the 21st Century, Fourth Edition, London and Delhi: Sage Publications.

Drache, Daniel. (2001) The Post Washington Consensus: The Market Disconnect and the Public Reconnect, Working Paper of the Robarts Centre for Canadian Studies, February.

Fine, Ben. (2002) "Economics Imperialism and the New Development Economics as Kuhnian Paradigm Shift,” World Development, Volume 30, Number 12, pp. 2057-2070.

Jayasuriya, Kanishka. (2001) Governance, Post Washington Consensus and the New Anti Politics, Working Paper of the Southeast Asia research Centre (SEARC), City University of Hong Kong, Number 2, April, 13pp.

Nikiforos, Laopodis T. (2001) “Effects of Government Spending on Private Investment,” Applied Economics, Volume 33, pp. 1563-1577.

Onis, Ziya and Fikret Senses. (2003) Rethinking the Emerging Post-Washington Consensus: A Critical Appraisal, ERC Working Paper in Economics 03/09, Economic Research Centre, Middle Eastern Technical University, Ankara, Turkey, November.

Tool, Marc R. and Paul Dale Bush, (eds) (2003) Institutional Analysis and Economic Policy, Boston, MA and London: Kluwer Academic Publishers.

Wade, Robert Hunter. (2004) “Is Globalization Reducing Poverty and Inequality?,” World Development, Volume 32, Number 4, pp. 567-589. 


\section{Index}

accounting standards 42-44, 51, 166, 222

accumulation of capital 17, 37-39, 45-46, 49-50, 53, 68-69, 75-79, 159, 161, 163-164, 167-169, 181-182, 207

advanced nations $4,10-11,54,138-152,159-175,181-201$

Africa 1-2, 5, 9, 11, 22, 38-39, 41-42, 54-55, 73, 78-81, 83, 87, 96-97, 99, 132-133, 206, $214-$ 217, 230

Age of Capital 8

Aglietta, Michel 12, 16, 112, 153

Agosin, Manuel 79

agricultural and manufacturing sectors 14, 107-109, 215-218

AIDS 1-2, 80, 87, 206

Al Qaida 53, 120-121, 130-133, 227

Albelda, Randy 62

Amjad-Ali, Charles 121

Arestis, Philip 169

Arrighi, Giovanni 25

art, theatre and film 34

Aschauer, D.A. 235

Asia 1-2, 4-5, 9, 11, 38-39, 43, 46, 52, 54-57, 58-59, 73, 78-80, 82-83, 87-88, 94, 96-101, 106108, 120, 132-133, 147, 206, 208, 215-216, 219, 222

Assassi, Libby 111

asset-based reserve requirements 225, 237

Association for Evolutionary Economics (AFEE) 46, 152, 201

Association for Social Economics (ASE) 111, 133, 201

automatic and discretionary stabilizers 50

axis of evil 20, 53, 121

Baker, Dean 155

balance of payments 92, 146

Balasubramanyam, V.N. 216

bank holding companies 163, 171-173

Baran, Paul 24

Bell, Daniel 34. 41

Berry, Brian 27

Bin Laden, Osama 22, 120, 131, 133

Binswanger, Mathias 59-60, 63, 167-168, 176

biotechnology 6, 95, 149, 165, 233

Bloch, Harry 153

bootstraps mechanism 15

Bougrine, Hassan 133

Bowles, Samuel 16, 49, 62, 84, 119, 193, 237-238

Boyer, Robert 153 
Brenner, Robert 12, 76

Brinkman, Richard 46

British hegemony 6, 8, 10, 15, 26

Brown, Doug 36, 46

Brown-Collier, Elba K. 111

Bush, Paul Dale 213

business cycles 2, 12-13, 15, 38, 43, 60, 139, 144-145, 147-152, 166, 172, 174, 207, 215, 221

capital and labor 11, 16-17, 23, 38, 49-50, 52, 88, 93-98, 106, 139, 143-145, 207

capital controls 52

capital flows 52-53, 72-83, 92, 99-101, 146-148, 211, 223

capitalism 1, 3-5, 7, 11, 13-14, 18, 20-21, 34-46, 52, 88-89, 139, 143-144, 160, 181-182, 192, 209-210, 234

Caribbean 1, 79

Casey, Catherine 95

Cato Journal 107

cell phones 37

Central Intelligence Agency (CIA) 130-131

ceremonial encapsulation 198, 216

Chang, Ha-Joon 216-217, 235

Chattel circuit 163-164, 167

Chossudovsky, Michel 131

circuit of social capital 90-94, 97-98, 103, 108-109, 110, 139, 159-164, 183-186, 195

circular and cumulative causation 15, 24, 35, 73, 77, 89, 125-126, 128, 150, 213

Ciscel, David 189

class, race and gender 182-184, 186, 193-195, 232

class conflict and struggle 16-17, 23, 38, 143-144

classes of capitalism 2, 7-9, 17, 38, 91, 143-144, 151, 182, 191, 193-195, 197-201, 212, 229-233

Cohn, Steve 83

Cold War 53

community associations 23, 181-182, 184-185, 190-192, 200

competition and monopoly 14, 16-17, 23, 36, 49, 68-70, 73, 76-77, 82, 93, 170, 173, 185, 206207, 230

complexity 2, 7, 187

computing and electronics 75-76, 227

confidence, stability and trust 38-43

conflict and power 4, 49-50, 92-93, 103-110, 159-160, 164, 166-169, 174, 186, 197, 206-210

conspicuous consumption and emulation 57, 166, 183

consumer and capital goods sectors 14-15, 185

Contingent Credit Line 93, 101-102, 112

contradictions 4, 8-9, 12, 16, 20-24, 34-6, 54-61, 69, 74-83, 93, 123-133, 138-139, 145, 148152, 164-175, 183, 188-189, 195-201, 206-210, 233-235

Cooper, Russel 95

core institutions 3, 16

core-periphery dynamics 5, 7, 9, 15, 53-57, 73, 77-83, 206-209, 214-218, 234

corruption 81, 213

creative destruction 1-2, 35-46

crises and instabilities $1-2,5,8,11,13,17,23,43-44,54-56,73-83,87-88,121-133,141,146-$ 152, 164-170, 174-175, 183, 189, 190-201, 206-210

crowding-in and -out effects 59-60, 78-80, 214, 234

Cullenberg, Stephen 27 
cultural capital 28

cultural contradictions 34-46, 189-201, 209

culture 23, 28, 34-46, 108, 122, 182-201, 209, 229-233

customer satisfaction 161, 169, 173-175

Danielson, Anders 27

Davidson, Paul 223-224, 234

Davis, John 27, 111

debt crises 5

deforestation 1

demand 2, 10, 16, 18, 21-24, 38, 59-60, 87-98, 138, 138-139, 146-152, 159-160, 165, 184-186, 206, 209, 221, 224, 234

DeMartino, George 235

democracy 190, 192, 230, 232

depression 8, 11, 26

deregulation 20, 23, 41-43, 52, 61, 92, 98-101, 129-130, 161-163, 170, 173, 209-210

Devine, Jim 83, 133, 175

dialectics 34-46, 83-84

discrimination 194, 198

disembedded economy 10, 17, 91, 160-161, 189-202, 209, 230

Doctrine of Preemptive Strike 45

drought and famine 2

Duijn, van J.J. 25

Dunning, John H. 112

Eastern and Central Europe 5, 9, 11, 21, 38, 41-43, 54-57, 73, 78, 81-83, 87, 96-101, 119-120, 133, 147, 206-208, 222

Eastern Economics Association 133

economic growth 2-3, 23-24, 49-51, 55-61, 139-140, 144-145, 167-169, 198-199, 207-210

economic surplus 26, 68, 209

economies of scale/scope 142, 163, 214

Edwards, Richard 16, 25

electronics 6, 95, 142-145, 162, 190

Elsner, Wolfram 216

endogenous money and credit 46, 60-61, 99, 162-163, 185

endogenous processes 4, 13, 21, 35, 46, 183, 195, 211

Enron, Global Crossing and WorldCom 44, 166, 222

environmental issues 24, 39-41, 88, 93, 108-109

equity markets $60-61,140,147-151,162-169,209,224-225$

ethnicity 2, 18, 23, 181-202

Europe 1, 7, 11, 39, 52, 58-59, 94, 96-97, 106-107, 120, 132-133, 151, 169, 173, 182-183, 206209, 219, 222, 231-232

exchange rates 52, 59-60, 146-148, 211

exports and imports 37-38, 72-73, 77, 146-147, 151, 211

fads, fashion and style $36-37$

family 11, 15, 49-50, 139, 182-189, 190, 193-197, 200-202, 233

family-community relations 18-24, 39-42, 49, 138, 152, 181-202, 209, 213

family-community social structure of accumulation (FCSSA) 181-202, 210

fatalities 123-126

Federal Reserve Bank 99, 148, 176 
feminism 183, 190

Fernand Braudel Centre 15

fictitious capital 42, 209

finance capital $6,11,23,41-44,163,183-184$

financial crises 1, 43-44, 54-56, 81, 98-103, 206

financial instability hypothesis 111-112

financial social structure of accumulation (FSSA) 159-175

financial (in)stability 51, 54-56, 59, 87, 92-93, 98-103, 138, 147-152, 159-175, 206

financial system $11,16,18-20,22,49,51-52,54-56,92,98-103,138-139,147-152,159-175$, 183-185

Fine, Ben 212, 235

First World War 10

fiscal policy 51, 57-61, 163, 210-211, 220-221

flexible system of production 94-96, 143

Fordism 6, 10, 11, 16, 68, 138-139, 182

foreign direct investment 20-21, 37-38, 45, 69, 71-74, 78-83, 214-215

Forrester, Jay 13-14

Forstater, Mat 175

Frank, Andre Gunder 4, 27

Fraumeni, Barbara 153

free trade and protection $10-11,52,107-110$

Freedman, Lawrence 121

Freeman, Christopher 15, 154

French and American revolutions 5

French revolution 7

Frey, Bruno 126

functional finance 220

Gabb, Anthony 12, 153

Gelderen, van J. 13

gender 181-202

General Agreement on Tariffs and Trade (GATT) 104-105, 109

General Agreement on Trade in Services (GATS) 105, 107

general theory 9

genuine progress index (GPI) 39-41

geographical mobility 23

Gilman, Joseph 27

Gintis, Herbert 193, 237-238

global circuit of capital 90-94, 97-98, 103, 108-109, 110

global commodity chains 71, 82, 84, 206, 215, 217

global cooperation 228-229

global governance 19-20, 49-62, 206-235

global military social structure of accumulation 119-133, 138

global mode of regulation $87-110$

global political economy 1-3, 7, 16, 19-20, 34-46, 49-61, 68-83, 87-109, 119-133, 206-235

Global System of Power and Accumulation 19-22, 35-46, 51, 68, 87, 138, 207, 209

global warming 1,53

globalization 1-2, 6, 10-11, 17, 35-42, 129-130, 162-163, 208, 216

gold rushes 5,8

Goldstein, Jonathan 28, 153, 201

Goldstein, Joshua 27 
Gordon, David 16, 26, 28, 49, 153

Gordon, Robert J. 145, 154

governance 4, 19-20, 49-62, 79-83, 98-110, 184-185, 206-233

government spending 43, 50, 57-61, 96, 146-147, 185, 207, 218-221

Grabel, Ilene 217, 235

Granger causality 168

Great Depression 10

gross domestic product 2, 21, 39-41, 51, 54, 61, 72, 77-78, 80, 82, 96-97, 139-140, 144-148, 150, 165,167

growth and development $3-4,11,15,18,20-22,35-46,53-55,70-82,109,138,181-183,199$, 208-211, 219

habits 2, 4, 18, 25

Haley, Shawn 188-189

Hansen, Alvin 14

health and education 21, 24, 58-59, 105, 193-194, 197, 207, 218-220

Heath, Julia 189

Heller, Patrick 237

Helliwell, John 202

Helphand, Alexander 13

heterogenous agents 182-202

historical time 3, 14-15, 21, 35

Hobsbawm, Eric 7-9, 24

Hodgson, Geoffrey 25, 192

holistic growth and development 214-218

holistic method 3, 7, 17, 24-25, 35-37, 46, 213-218

Hossein-Zadeh, Ismael 12, 153

hot capitals 43, 46, 92, 99, 208, 211

household labor 182-183, 187

Hout, Wil 84

human capital 28, 36, 193

Huntington, Samuel 121

ideology 15, 51

imperialism 6, 10

Index of sustainable economic welfare (ISEW) 39-41

individualism 23-24, 37-38, 41-42, 188-189, 193, 195-196, 229, 233-234

industrial revolution 6-7

industry and finance $21,23-24,35-36,41-44,50,58-61,92-93,139,159-175,208-209,222-$

225, 234

industry policy 216-218

inequality 51, 56-57, 151-152, 181-182, 186, 192-202, 228-233

infant mortality 81

inflation 167, 174, 221

information and communications technology (ICT) 6, 23, 93-95, 141-145, 163, 209

infrastructure and telecommunications $24,59-59,199,212,218-220$

innovation 1, 4, 13, 15-16, 36, 45, 52, 55, 70-73, 80, 82, 92, 99, 143, 161, 164-165, 167, 170, 173, 190, 208, 211, 215-216

institutional economists 34-35

institutional innovations 4, 206-235

institutions 1-3, 5, 7-8, 10-12, 14-18, 20-24, 49-61, 87-90, 138, 159-175, 181-201, 206-235 
interdisciplinary or transdisciplinary perspective 3

interest rates 59-60, 140-141, 161, 165, 167, 170, 211

International Criminal Court 53, 132

international financial architecture 43, 46, 87, 98-103

International Monetary Fund 4, 22, 43, 46, 54, 56, 80, 87, 98-103, 236

international relations $20,22,44-45,53,119-135,225-229$

Internet 37, 44, 95, 142, 149, 227

investment 16, 36-40, 42-43, 58-59, 68-83, 91-92, 96-97, 141-142, 146-148, 167, 197, 198-200, 208, 217-219, 230

Iraq War 53, 121, 131-132, 228

Islam 120-133, 228-229

Islamic culture 45, 129-132, 228-229

Jackson, Pamela 46

Japanese management techniques 95, 111

Jessop, Bob 16, 27, 94

Jorgenson, Dale 154

Journal of World-Systems Analysis 15

Juglar cycles 13

just-in-time inventory management 88, 93-94, 142, 227

Kaldor, Nicholas 16, 90-92, 214

Keynes, John Maynard 35, 42, 160, 224

Keynesian economics 14

Keynesian-welfare state 6, 10-11, 16-17, 20, 49-51, 183

Kitchin cycles 13

Klinger, Scott 236

knowledge and skills 2, 128-129, 142-143, 199, 216

Kondratieff, Nikolai 13-14

Kondratieff waves or cycles 4, 8, 10-11, 13, 98

Kotz, David 17, 62

Kriesler, Peter 153

Kuznets, Simon 14

Kyoto Protocol 1, 53, 132

labor process 8

Landefeld, J.Steven 153

Lange, Oskar 14

Larson, Sven 175

Latin America 1, 5, 9, 11, 21, 38-39, 41-43, 54-56, 73, 78-81, 83, 87, 94, 96-97, 99-101, 147, 206-207, 211, 212, 214-217, 222

Lebowitz, Michael 27

lender of last resort 11, 43, 100-103, 112, 222-223

Lerner, Abba 220, 236

liberal capitalism 7, 138

Lipietz, Alain 16, 94, 153

Lippit, Victor 12, 83, 153

long wave theories $13-28$

long waves of growth and development 3-28, 39-46, 49-50, 59-61, 87-90, 138-152, 159, 174, 181, 200-201, 206, 209, 215, 221 
long-term performance 3, 15, 18, 46, 59-61, 88, 144-146, 152, 160-161, 167-169, 175-176, 182, 200-201, 206-210

McDonough, Terrence 62, 201

Madden, Gary 95, 142

Maddison, Angus 5, 54, 80

Mandel, Ernest 14, 28

Mann, Michael 131

markets 10-12, 16-17, 20, 23, 36, 38-45, 49, 160-162, 165, 168, 170-171, 183-185, 199, 207, 211, 230

marriage and divorce 187-189

Marx, Karl 13-14, 35, 42, 160

Marxist political economy 27, 84

Mayer, Ricardo 79

Mensch, Gerhard 15

mergers and acquisitions 21, 72-74, 80, 82, 163, 173

Middle East 1, 21, 38-39, 44-45, 87, 96-97, 120-133, 206, 208-209, 214-217, 225-230

minimal dislocation 213

Minsky, Hyman 111, 160

Mishkin, Frederick 176

mode of consumption 16-18, 139, 146-152

mode of regulation (MOR) 16, 18-24, 39, 51, 87-110, 138-152, 206, 208

monetary policy $23,51-52,57-61,162,207,211,220-221,224-225$

monetary theory of production 160

Moseley, Fred 12, 153

Mueller, Dennis 74

Myrdal, Gunnar 128

NASDAQ Index 97, 149-151, 164-165, 237

neo-conservatives 20, 44-45, 53, 228

neoliberal social structure of accumulation 49-61

neoliberalism 1-2, 4, 11-13, 17, 20-23, 37-38, 41-44, 49-61, 98, 138, 143, 161, 173, 195, 207, 211-212, 219

Nesiba, Reynold 46, 83, 133

networks 18, 20, 125-126, 142, 160, 194-195, 215-216, 231-233

New Deal 182

non-government organizations (NGOs) 51

nurturance gap 189

Oakley, Allen 26

Oceania 11, 39, 55-59, 87, 120, 122, 182, 209

O’Connor, James 27

O’Hara, Phillip 12, 24-25, 175

off balance sheet activities 173

offshore banking centres 43

oligopolies 10, 68

organic composition of capital 14

overproduction and underconsumption 9, 15

Palestine and Israel 1, 44, 53, 87, 120, 122, 129-131 
Palley, Thomas 150, 225, 237

paradox of individual vs system 35-46

Parker, Mike 95

path dependence 2

patriarchal family 11, 182, 187, 189

Paxton, Pamela 190

Perelman, Michael 76, 83

Perez, Carlota 16, 27, 95, 142

Pietrykowski, Bruce 153

Polanyi, Karl 10, 35, 91, 161, 196

political economy 14-18, 24, 28, 49-50, 138, 213, 235

political economy: definition 3

political economy: principles 24

political scientists 2

political stability 81

postmodernism 34

post-neoliberal governance (PNG) 206-235

post-Washington consensus (PWC) 210-213

poverty reduction and relief $46,56,100-101,212$

power 2, 5, 7, 14, 19-24, 45-46, 49-50, 52-53, 143-144, 206

Prebisch-Singer hypothesis 80, 215-216

privatization 41-42, 51-52, 56, 58-59

production and distribution 16, 68, 88-98

production-money-trade MOR/SSA 19-22, 89-110

productive-unproductive activities $21,58-61,92,161,163,166-169,186,199-200,207,209,214-$ 221, 218-221, 234-235

productivity $7,11-12,17,20-22,24,38-39,45,54-55,74,77,80,83,87-96,138-139,142-145$, 152, 161-163, 169-174, 183, 209, 229

profitability 9 , 11-12, 14-15, 17, 21-23, 36, 38-39, 45, 50, 52, 69-70, 74-77, 83, 140-141, 152, 159, 169-173, 181, 207, 221, 230

protecting the poor $43,46,100$

prudential functions 43,102

psychic income 40-41

psychological well-being 39-42

public capital 58-59, 96, 199-200, 218-220, 234-235

public goods and systems functions 17, 34-6, 49-53, 58-59, 87-93, 142, 159-161, 170, 174-175, 181-201, 216-217, 220, 227-228, 230-234

Public Information Notices 93, 101

public utilities 51, 58-59

Putman, Robert 189-190, 202

quality of life 143, 187, 197-199, 209-210, 229

radical Islamic forces 44-45, 119-133, 226-229

Raffer, Kunibert 80

Reati, Angelo 235

recession 1, 23, 38-39, 44, 88, 98, 138, 143, 159, 161, 194, 206, 222

regime of accumulation 16, 18-21, 88-90, 93-98, 110, 138-152, 208

regulation 45, 50, 53, 183

regulation approach $16-21,87-110$

Reich, Michael 16, 83 
Reijnders, Jan 28

rent seeking activities 36, 74-75, 210

reproduction, socioeconomic $2,16,22$, 34, 34-6, 88-91, 139, 161, 181-202

research and development 68, 75, 142, 215, 217

Resnick, Stephen 130, 182

Review of International Political Economy 111

Review of Radical Political Economics 153, 175

revolution 14

risk 173-174, 209

Rosenberg, Samuel 62

Rostow, Walt Whitman 14, 24

Ruccio, David 153

Rude, Chris 175

rule of law 81

S\&P 500 Index 97, 164-165

sabotage 126, 227

safety nets and support networks 46, 93

Sapsford, David 216

schooling 81

schools of political economy 24

Schumpeter, Joseph 12-15, 35, 42-43, 84

Second World War 10, 49-50, 122, 182

segmented labor markets 10, 139

sexual liberty 34

Shaikh, Anwar 27

shareholder value 1, 23, 140, 142, 162-164, 169

Sherman, Howard 122, 133

Sklar, Holly 236

social capital 18, 28, 41-42, 39-46, 102, 181-186, 189-192, 194-198, 200-202, 229-233

social fear and intimidation 123-126

social instability and fragmentation 23-24, 35-46

social overhead capital 7

social relations 7, 18, 22, 139, 142-145, 181-202, 209

social structures of accumulation (SSA) 16-24, 39, 49-61, 68-83, 89-110, 119-133, 138, 141, 152, 159-175, 181-201, 206-210

social wage 17,50

socialism and communism 10, 22, 44-45, 130, 182

socioeconomic performance 12, 35-46, 53-60, 119, 138, 183, 195-201

Solomou, Solomos 28

Special Data Dissemination Standard 101-102

speculative bubbles 23, 44, 59-61, 87, 96-97, 148-151, 164-169, 208-209, 213, 222, 225, 234

stability:

social and financial 23, 38-46, 49

standard of living 1, 55-57, 102, 197-198, 209-210

Stanfield, James Ronald 34, 46, 189, 201

Stiglitz, Joseph 211-212, 218, 235

Stockhammer, Engelbert 169

structural forms 16, 18, 20, 22, 88-89, 138-139, 152, 159-201

successive approximation 13

Supplementary Reserve Facility 93, 101-102, 112 
supply 37, 58-59, 226

surplus value 90-92, 159-160, 184-186

Sweezy, Paul M. 14

system of production-distribution 87-91, 93-98

systemic circuit of social capital 183-186

Systems Dynamic National Model Project 14

Taliban 44, 53, 121, 130-131

taxation 50, 52, 58-59, 140-141, 211, 218, 220-221, 223

taxes-drive-money 220-221

Taylor system 10, 26, 94, 143

technological change 2, 4-5, 13, 17, 23, 68, 72, 75-76, 95-97, 139-142, 147, 170, 196

technological innovations 4, 7, 10, 13, 36-39, 72, 75-76, 95-97, 139-142, 170, 215-217

technologies 3, 8, 10, 13, 15, 21-24, 68, 72, 75-76, 94-96, 126-128, 139-142, 161-162, 170-171, 182, 196, 226-227, 214, 229

technology/production style 7-8, 18, 88, 94-96, 141-145

telecommunications 68 , 75-76, 107, 142, 218-220

terrorism 1, 4, 19, 22-23, 44-45, 51, 87, 119-133, 138, 206, 208, 226-229

terrorist multiplier 134

Thatcher and Reagan revolutions 11, 50, 210

Tilly, Chris 62

Tisdell, Clem 76

Tobin Taxes 103, 223-224, 234, 237

Tonak, E.Ahmet $2^{7}$

Toporowski, Jan 235

total quality management 88, 93-95, 142

Trade-Related aspects of Intellectual Property (TRIPS) 105

Trade-Related aspects of Investment Measures (TRIMS) 105

traditional values and institutions 34, 183

transmission mechanisms 59-61, 147-151, 165, 196-201

transnational corporate social structure of accumulation 68-83

transnational corporations 4, 19-20, 38-39, 68-84, 138

Trotsky, Leon 13-14

trust 18, 20, 23, 38, 41-42, 45-46, 76, 166, 181-186, 189-192, 194-198, 200-202, 207, 229-233

Tugan-Baranowski, Mikhail 13

Tylecote, Andrew 16, 27, 95, 142, 153

uncertainty 1, 17, 22-23, 37-45, 92, 119, 123, 127-128, 162, 167, 169, 173, 183, 195-201, 208209, 214

unemployment 10, 37, 39, 140, 145

uneven development 3, 35-46, 54-58, 184, 195, 206-209, 214-218

unilateralism 35-36, 44-45, 51

Union for Radical Political Economics (URPE) 83, 175

unipolar "antiterrorist” social structure of accumulation 119-133, 138

unipolar military system 19, 21, 119-133, 225-229

United Nations 121, 132, 223

United States 1, 4, 7, 9, 20, 22, 25, 37-45, 53-61, 87, 96-97, 106-107, 119-133, 138-152, 159175, 181-202, 206, 208-210, 215, 219, 222, 226-229, 232

United States hegemony and power 1, 4, 6, 10-11, 15-17, 20-24, 44-45, 49, 53, 61, 119-133, 183, 208, 225-229

unstable and uneven performance 35-46, 53-58, 129-130, 214-218 
upswings and downswings $8,11-12,17,23,50-51,54-56,74-75,77-83,87-88,138-139,144$ 146, 174-175, 206-210, 215, 230

US System of Power and Accumulation 19-20, 23, 138-201, 209

values 7,183

Veblen, Thorstein 9, 35, 42, 126, 160

Vietnam War 11, 17, 50, 119, 183

Wallerstein, Immanuel 4, 27

war 2, 14, 23, 81, 87

war on terrorism 3-4, 120-133, 226-229

Washington Consensus 98, 210-212

Watchel, Howard 237

wealth effect 97, 147-151, 164-165

Weisskopf, Thomas 16, 27

Welch, Patrick 201

welfare state 11, 218

Went, Robert 17

Williamson, John 210

Wilson, Matt 83

Wolff, Edward 27

Wolff, Richard D. 130, 182

Wolff, Sam de 13

Wolfson, Martin 18, 49, 62, 159

worker cooperatives 232

working people 2

World Bank 54, 210, 216, 223

world income 92

World Trade Organization 4, 22, 80, 87-88, 103-110, 208, 218

World Value Survey 41-42

World-Systems 15, 35, 121

worldwide web 2

Wray, Randall 221, 236

Yaghmaian, B. 12, 153

Yates, Michael 153 